\title{
THE WORLD'S MEAT FUTURE
}




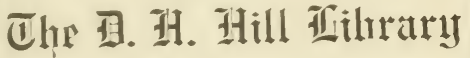

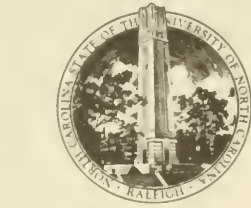

Ninth Caruliua

$\mathrm{SF} 41$

$\mathrm{P} 4$ 
This book is due on the date indicated below and is subject to a fine of Din CENTS a day thereafter. 



\section{THE WORLD'S MEAT FUTURE}

An Account of the Live Stock Position and Meat Prospects of all Leading Stock Countries of the World, with Full Lists of Freezing Works.

BY

A. W. PEARSE, F.R.G.S.

Editor of "The Pastoral Review."

Melbourne, Sydney, Adelaide, Brisbane, Perth, Launceston.

With Introduction by SIR OWEN COX, K.B.E. Commonwealth Meat Adviser.

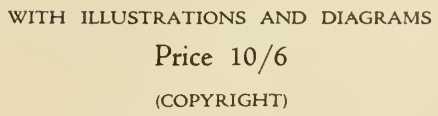





\section{INTRODUCTION.}

ONE of the most important questions at the present time, when the peace negotiations are settled, is that which forms the subject matter of this book. Everybody wants to know what is going to be the position of the meat supply, and all sorts of prognosticatious are being given expression to. No one should have a better idea of the possibilities of stock raising in various countries than Mr. A. W. Pearse. For twenty-seven years he has been closely identified with the meat industry, not only in Australia, but in most of the stock raising countries of the world. The newspaper of which he is the editor and proprietor (The Pastoral Review) circulates in all stock countries, and I don't suppose there are many men interested in the meat trade, who do not eagerly look for and read the information he supplies. His paper alone has wellpaid representatives and experts in most countries where stock are reared, and direct and anthentic information and tables of exports are regularly forwarded by them. So satisfied are the meat firms of Australia and New Zealand with his capability and knowledge, that on two occasions he has been the representative of all the meat exporting companies of Australia and New Zealand at International Congresses, the first in Paris, in 1908, and the second in Chicago, in 1913. At the last conference, he also represented the Federal Government of Australia, and read a paper on the world's meat export trade before a vast gathering of experts from all over the world. Most of his knowledge has been gained first hand, he has visited the States of South America and Africa several times, and when the war broke out, was booked for a trip through Siberia to gather information and prospects there. There may be readers who will not agree with all his conclusions, but I have no doubt the information he gives will add largely to our knowledge of what we can expect in the way of meat supplies in the near future. The Pastoral Review, of which he is editor, is certainly looked upon by those concerned in the trade, as the standard paper and "enquire within" for all matters connected with live stock and meat exports in all parts of the world.

\section{E. Owen Cox, K.B.E.}

Commonwealth Meat Administrator. Deputy Controller of Overseas Shipping. Member of the Commonwealth Government Shipping Board. Chairman of The Overseas Central Committee, which has the disposition of the whole of the tonnage loading oversea from Australia and British Government tonnage. Director in Australia for the Federal Steam Navigation Co. Ltd., and Chairman of Directors of Birt \& Co. Ltd., Australia. Chairman of the Australian Frozen Meat Shipping Committee for the Imperial Government.

Sydney, Nov. 6. 1918. 



\section{FOREWORD.}

In venturing to publish this book, the author does so with the hope that it may be of service to those interested in the food problems which are before us. It should also be of use to those stock-owners all over the world who are anxious about the future of the stock-raising industry. In describing area, elimate, and pastoral conditions of some of the Central American Republics not visited by me during recent years, I have had recourse to those splendid books, The Great states of South America, by C. W. Domville-Fife; Brazil and the Brazilians, by G. J. Bruce; Brazil in 1913, by .J. C. Oakenfall ; Argentine and Lruguay, by Gordon Ross; and Central America, by W. H. Koebel.

It will be seen that I am not pessimistic as regards the meat supply of the future, and I hold that for many years cattle and sheep raising are going to be the most profitable of all industries. There are no better prospects for young men than in the healthiest and eleanest of all professions - that of stock raisingprovided that before they launch out on their venture they obtain the necessary practical knowledge and experience. Wool and meat will always be in strong demand, and there is no sign that either will be in over supply for many years. Governments must assist and not handicap the stock-breeders, and minimum prices, not maximum, shonld be the rule if prices have to be fixed at all. The cities are entirely dependent upon the producer. "Destroy your country, and the grass will grow in the streets of your eities, but make the country prosperous and the eities will jump ahead in prosperity.'"

The AUthor.

Nor. 6th, 1918. 


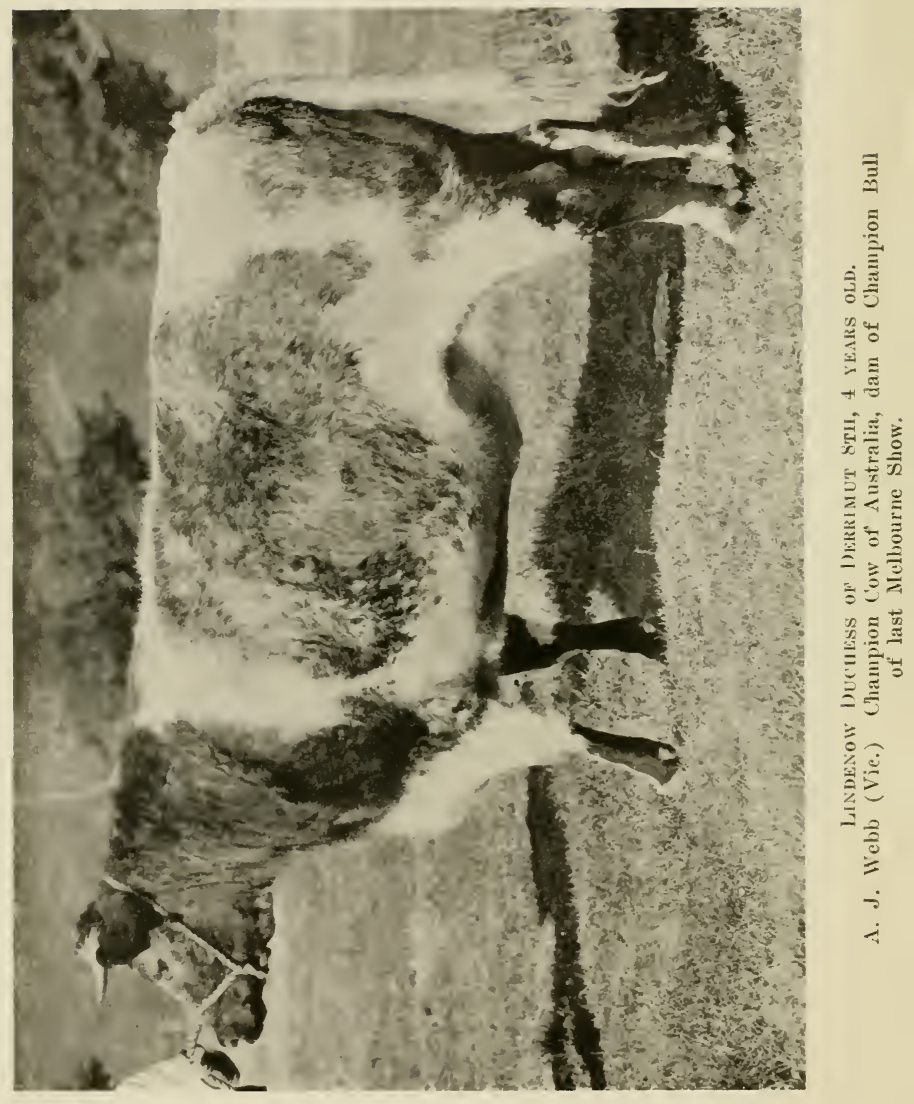




\section{The World's Meat Future.}

Lord Harcourt recently said in the House of Lords that while he was aeting as President of the Board of Trade, in 1916, he acquired information which eaused him the greatest anxiety in regard to the meat supply, and added, "After the war there would be a searcity of meat-almost a war famine. Germany, Belgium, and IIolland were faced with a post war deficit of $8,000,000$ head of eattle, and Demmark, Austria, Servia and Rommania another 8,000,000. Europe, therefore, would seek to import from 16 million to 20 million head of cattle. Britain produces only 60 per cent. of the meat consumed. He was, himself, so impressed with the serionsmess of the position last year that he sought to arrange a seheme for securing a supply of chilled meat, whieh would be ample for Britain for several years after the war."

This statement, by a prominent British statesman, is of sueh vital importance to the Empire that to the best of my ability $I$ am going to place before those who eare to read it, the position to-day in the various stoek raising countries of the world.

In commeneing I must say that I fear the information given to Lord Hareourt must have been of a hasty charaeter. Granted that the shortage in the seven European countries named would amount to $16,000,000$ head of eattle, that does not mean that a similar number or more would have to be imported to make up the shortage. First of all there will be probably $16,000,000$ to $20,000,000$ adults less to eat meat, and the children, or those of them left alive, will not by any means require mueh meat for a few years after the war. Probably countries like Denmark, Holland, Germany and Austria will have kept a very large proportion of breeding stock, and in three or four years a very large increase of young eattle ean be looked for, partienlarly if they buy bulls from Britain, United States, or Canada, where there is plenty of young male stoek available. Neantime people will have learned economy, the use of horse and whale flesh, and the larger use of fish and eereals, also that there is not the neeessity they imagined for so big a meat diet. 
As regards Great Britain's meat supply, the war has in no way diminished her flocks and herds; in fact, if anything, they are larger than before the war; the total eattle at the end of 1916 being $12,451,450$, and the sheep $28,849,655$. Imagine in little Britain 2,000,000 more eattle than in all Australia. This is the more wonderful when we realise that over $2,500,000$ acres of grazing lands have been put under crop. The British people have also learned the mueh needed lesson of economy, and after the war there will not be the enormous waste there has been in the past. Cold meat will not again be thrown away wholesale to the pigs and the $\operatorname{logs}$, it will be utilised as it should be. Again many foods have taken the place of meat, and the people have discovered that they are much healthier on a smaller meat diet. Taking the population of Greater London, which represents roughly the area supplied from Smithfield, at 7,500,000, it ean be seen that the Capital is now apparently consuming much less meat than before the war, the quantity marketed during 1917 being only $1.62 \mathrm{lbs}$. per liead per week, i.e., inclucling baeon, poultry, game, etc., as against $2.48 \mathrm{lbs}$. per head in 1913 . The Empire's armies will get back to Anstralia, New Zealand, Canada, and India, where there is more than ample meat for all their wants, and it will be found that instead of 37 per cent. of meat having to be imported, whieh before the war was Britain's requirements from abroad, probably 20 per cent. or 25 per eent. only will be needed. Sixty-three per eent. of the total meat supply of Great Britain before the war was home grown. Of the imported meat supply (37 per cent.), Argentina supplied 80 per cent. of the beef, and Anstralia 12 per cent., the balance coming from various sources. New Zealand supplied 40 per cent., Australia 25 per cent., and Argentina 29 per eent. of the imported mutton and lamb.

The flocks and herds in France have not decreased since 1916, in fact they have increased, but from the commencement of the war until that year, the sheep flocks fell away by 30 per cent. With the introduction of studs from Britain, however, they will rapidly gain in number and in weight. In July, 1917, their Census Returns aecomnted for 12,443,304 eattle, 10,586,5.94 sheep, and 4,200,280 pigs. Supplies of home-grown meat for the civil population were aceordingly fairly plentiful. It must ever be remembered that there are many countries in Europe with enormons populations which make grain of various sorts their main food supply; therefore, in investigating 
the requirements for meat, it is well to remember this important factor and those eountries ean be put on one side, as their food supply will eome out of the gronnd. Again there are many nations whose people are meat eaters who are not so fastidious as we are and use horse flesh, whale flesh, and other meats which the average Britisher or American refuses to touch.

The world's export output of frozen and chilled beef, nutton and lamb in 1917 was estimated at 965,000 tons, as against 915,380 tons in $1916,881,075$ tons in 1915 , and 800,375 tons in 1914-a steady rate of expansion which was very satisfactory, under war eonditions. From these yearly totals, about 386,000 tons, 381,569 tons, 218,150 tons, and 105,948 tons respectively were diverted to markets other than the United Kingrlom.

The nations which are mainly beef, mutton, and pork eaters ane the British Empire, Tnited States, Germany, Franee, and a few other smaller countries in Europe : also most of the South Ameriean Republies. These are the countries whose supply and demand must be looked at when investigating the eondition and prospeets of the meat trade of the world, and I propose to take them in order of their importance.

Many of the eountries I shall deseribe have been visited by myself during the last thirty years with the particular object of studying their pastoral eapabilities for the information of the graziers of Australia and New Zealand. Therefore this matter of stock and meat supplies eomes in very opportunely. Russian requirements ean be left ont of the question. When they settle down again, introduce law and diseipline, and have shot the men who have brought the eountry to its present pitiable condition, they will be ahle to draw what meat they will temporarily require from the vast plains of Siberia, Nanehuria, and ('hina, where there are great herds of eattle available. Hard times for a year or two will be the fate of several of the Balkan States, but grain and potatoes are their prineipal foods as I have stated before. Argentina, Truguay, Australia, and New Zealand, by the end of the war, should have a very large beef reserve, as at the present time none of these eountries are shipping all their surplus. It is gratifying to see that Sir Henry Rew, the well-known food statistician, agrees with my view. In a reeent address before the Royal Statistical Soeiety, he said: "It appears that during the war a very substantial stimulus has been given to overseas trade in meat, and that sources of supply hitherto almost untapped have been 
developed. It is clear that what may be termed the old reservoirs from whence meat supplies have been drawn are expanding and are capable of further expansion. There are also new and rigorous competitors for the world 's trade."

Refrigerated tomnage after the war will be more than ample for all requirements, notwithstanding the submarines, Great Britain had more refrigerated tomage at the end of last rear than she had at the beginning of the war, and it must also be remembered that Italy, France, the United States, and other comtries are building up quite a big fleet of refrigerated steamers.

\section{THE FOLLOWING IS I LIST OF THE CHIEF S'TOCK-I'RODLCING COUNTRIES OF THE WORLD :-}

Australia.
New Zealand.
Argentina.
Brazil.
Yrugnay.
Ynited States.
Canada.
Paraguay.
Nexico.
Nicaragua.
Tenezuela.
Colombia.
Honduras.
Chile.
Guatemala.

Peru.

Rhodesia.

British East Africa.

Tnion of South Africa.

Bechuanaland.

s.W. Africa.

Nigeria.

Madagasear.

Egypt.

Sontan.

Abyssinia.

Somaliland.

Cameroons.

Algeria.

Manchuria.

All the above-mentioned comntries possess a more or less large supply of eattle of more or less good or bad quality. Most of them have vast areas of fine grazing land, many with excellent climate and with plenty of rivers. With one or two exceptions, they are countries fit for the white men to live and thrive in: many of them are sparsely populated, and land is to be obtained at moderate cost.

With the introduction of good stud bulls to those countries which are yet in their meivilised condition, the installation of numerous dips, and with stable governments, in a very few years they could most of them be brought to the meat exporting stage. 
The past experience in Argentina and Uruguay, and the present experience in Brazil, are sufficient to show the more backward countries what they can look forward to under modern business methods. The great need in most new conntries is for animals that will improve the native stocks so that they may increase in weight, shape and quality. That such animals are procurable in large numbers in Great Britain, the United States, Australia and New Zealand, is quite evident if one visits the magnificent stock shows in those eountries. Cattle and sheep are available of high-class quality, of all breeds, and to suit all climates and pastures, and directly the world settles down after this war madness is quenched, it is highly probable that men will be touring those countries and buying largely to improve their backward flocks and herds. The stud breeder is doing an international work, and should be encomraged by the Governments of the countries in which he is carrying on his good work.

The Latin-American Division of the U.S. Bureau of Foreign and Domestic Conmerce has prepared a report on the meatpacking industry in South America, with the view of showing that that country, with its increasing areas suitable for eattle raising and its meat-packing establishments, is in a position to play an important part in the world's meat production in the future. The report is as follows:

"One of the most serious questions confronting the countries of the world is that of the meat supply of the future. For nearly a decade the number of cattle has not been increasing in proportion to the demands of the growing populations. The decrease in the supply of meat has affected the United States as well as Europe. Russia, which before the war had some 50,000,000 head of eattle and two-thirds as many sheep as Australia, has ceased, temporarily at least, to be a factor in the European trade. The herds of western Europe, small before the war in comparison to the demands of the inereasing population, are now greatly depleted and cannot be replaced for many years after the war. The sitnation in the United States is reaching an interesting stage. Within the last ten years, the population has increased about 18 per cent., while the herds have decreasert 20 per cent. In 1893 the United States imported 3,293 head of cattle, and from its abundant supply exported over 287,000. In 1915, twenty-three years later, the import and export figures are practically reversed. In the latter year the United States exported only 5,484 head and imported 538,167 cattle. 
"Will South America, with its extensive areas suitable for eattle raising, and its growing meat-packing plants, help relieve the situation? The outlook in that direction is, incleed, farourable. Already Argentina and Truguay, and in a lesser degree Brazil. Colombia, and some of the other comtries, are figuring as meat-producing possibilities. In the development of this industry, the general installation of refrigeration by steamship lines has been of great service."

In South America stock breeding is a resultant inclustry of meat freezing. Before the introduction of refrigeration, salted and dried meat, tough and unpalatable, was in general use locally and exported in limited quantities to Europe. This meat is known rarionsly as jerked beef, in Argentina as tassajo, as xarque in Brazil, in Peru as charque, and as biltong in Africa. It is still used in some parts of South America and in the Tropics, where it is almost impossible to keep fresh meat, but it has never been popular in Europe. As the saladeros (meat-drying establishments) could make use of almost any animal, and since the demand was quite limited, there was really no incentive to breed fine stock.

Stimulated by the increasing demand from Europe for imported fresh meat, attempts were made to export cattle on the hoof. These, however, proved unsuccessful, owing to the outbreak of foot and mouth thisease and the extra expense entailed. Then the meat-packing and, indirectly, the stock-raising industries, were revolutionized by the introluction of refrigeration. This made possible the shipping of frozen and chilled meat. r'hilled meat has a much more delicate flavour than the solidly frozen meat, and normally brings $1 \frac{1}{2}$ to $2 \frac{1}{2}$ cents a pount more on the English market, but it must he used immediately after removing from cold storage.

Argentina is to-tay the most important beef-producing country of the world. Brazil is beginning to appreciate its own potentialities as a meat producer, ant is likely to become a powerful rival in the near future. Iruguay has maintained its important position, while Paraguay, ('olombia and Venezuela are among the countries that are receiving careful consideration from farsighted American and English packers. According to latest reports, there are at present more than sufficient refrigerating facilities to take care of the limited cargo space allotted, but it is the after-the-war situation that is being studied. 
The meat-packing industry of Argentina has been spared the hardships incident to the experimental stages of a new undertaking. Its market was already created; finely-bred cattle were available in Europe and the United States; it had but to model its packing houses along well-established lines. It was not until 1901, when the exports from the United States began to decline materially, that exports of Argentine beef began to assume importance: but since that date the increase has been steady and rapid. Anstralia and New Zealand, with a well-established trade in frozen mutton, supplied the markets for this product. In the beginning Argentina paid but little attention to the raising of hogs, so that the export of pork was of relatively little importance. During the period of 1908 to 1914 a decided change took place. The number of hogs in Argentina in 1914 represented an increase of 1,496,994 over the number in 1908 , while cattle and sheep showed a corresponding decrease. This would seem to indicate that special attention is being paid to the pork-packing branch of the industry. Another indication of the future tendency is the fact that the Armour company has equipped its new plant with facilities for handling 1,000 hogs in addition to the 1,500 cattle and 2,500 sheep per day.

England has been the principal market for Argentine beef, which it admitted free of duty, while many of the other European countries imposed prohibitive import duties. This condition is changing, due partly to the war demands; Italy and France are importing large quantities of frozen beef for their armies, and the United States has opened its markets to foreign meat.

With regard to the eurrent situation, Messrs. Weddell and Co., in their ammual report of 1917 , give interesting particulars, which are worth quoting in extenso:-

"The world's export output of frozen and chilled beef, mutton and lamb in 1917 is estimated at 965,000 tons, as against 915,380 tons in $1916,881,075$ tons in 1915 , and 800,375 tons in 1914 - a steady rate of expansion which must be considered very satisfactory, under war conditions.

"That this great industry has been mantained on so large a scale throughout the whole period covered by the war speaks well for the energy of suppliers, the efficiency of the British Navy, the pluck of the Mereantile Marine, and the enterprise of the Allied Governments, for whom the handling of the great bulk of these exports is now organised. 
"The official weights of the various deseriptions of frozen and ehilled meat imported into the United Kingdom in 1917, as well as the number of packages, are not available, but those for the previous four years, along with the approximate total import in 1917 , were as follow:-

1913

$\begin{array}{llllll}\text { Aestralia } & \ldots & \ldots & \ldots & 150,666 & \text { tons } \\ \text { New Zealand } & \ldots & \ldots & \ldots & 122,234 & , \\ \text { Argentine Republi } & & \ldots & 409,211 & , \\ \text { Other Countries } & \ldots & \ldots & 38,146 & \end{array}$

Total $\quad \ldots \quad \ldots \quad \ldots \quad 720,257$ tons

1916
1914

$\begin{array}{lr}143, \$ 53 \text { tons } & 124,572 \text { tons } \\ 142,700), " & 157.901 \quad, \\ 356,930, " & 293.909 \quad " \\ 50,938 \quad, & 86.543 \quad " \\ 694,427 \text { tons } & 662.925 \text { tons }\end{array}$

1917

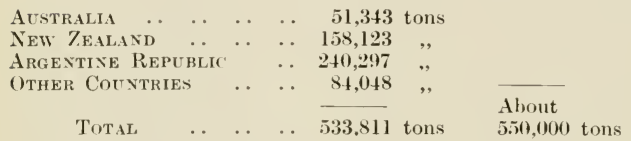

Argentina has been shipping very heavily also to the Inited States during the past two years.

\section{C'OLD S'TOR.ige IN THE UNITED Kingdom.}

"There has been a great deal of discussion lately, in the public press and elsewhere, on the proposals of the Government to increase largely the refrigerated storage aceommodation at some of the outports. The objects are (a) to avoid the necessity of steamers moving from one port to another in order to discharge their meat cargoes, and $(b)$ to admit of larger stocks being held.

" Much may be said in favour of both objects, but unless proper railway facilities for transport to and from the big centres can also be provided, cold storage alone is of little use at an outport. Ability to handle only one cargo in any outport is simply inviting delays in discharge, and unless really large stores can be fitted ip the advantages to be gained may be only visionary. It may be convenient to store goods at the first port of discharge, but it is more advantageous to store them close to the ultimate market. Apart from special Admiralty requirements in time of war, it is best to discharge steamers where they ean not only land a complete cargo, but reload a full cargo for export. To secure this would involve not merely the building of stores at edch unloading port, but the reorganisation of 
the railway service and the reconstruction on fresh lines of the whole export trade of the country. As a purely war measure, an increase in cold storage might be justined, but the necessity is not so pressing as it is sometimes made out to be. There are now between 80 and 90 cold stores in the country with accommodation for more than 1,000 tons each, their total storage capacity being 289,000 tons of meat stowed solid, or 230,000 tons stowed to marks for easy delivery. This represents abont four months' supply of the frozen meat imported in normal times. It does not take account of the very large number of small stores in the country, having a capacity of less than 1,000 tons each; but, on the other hand, it makes no provision for the large quantities of goods other than meat which must be stored in refrigerated chambers.

"If, after fuller expert consideration than the subject has yet received from traders, it be deemed prudent to launch ont upon any national scheme of store building, it might be well to consider the advantages of erecting stores of moderate size - say 1/2000 tons capacity-in every hig military camp in the country. Let all these installations be identical in plan, with standardised machinery and accessories; let them be of a temporary nature, capable of being readily removed to other sites; keep them filled with perishable foodstuffs, drawn direct from ship's side at any port at which meat is being discharged, or replenished from local supplies when these are plentiful. With cheap land, abundance of labour, and the minimum of difficulty about providing daily rations, such a method of storing food should prove much more economical than building large stores specially designed for each port, having no guarantee of constant employment during the war, nor of any employment at all in peace times."

\section{The Continent of Europe.}

"Last year, frozen meat business on the C'ontinent was again of a special character, inasmuch as deliveries, practically without exception, were made under Government Contracts for Army supplies.

"France.-Arrivals of frozen meat were regularly maintained at French ports throughout the year, so that the aggregate quantity imported was fully as important as during the preceding year. Precise figures, however, are not available. The whole import was utilised for feeding the Allied Armies, with the exception of relatively insignificant quantities which the 
Govermment at times allowed to be delivered to co-operative societies and municipal shops for civil consumption in Paris.

"Partly as a result of the steady importation of frozen meat, there was no further depletion of the French herds. On the contrary, these are believed to have recovered lost ground during the past year, and in July last the Census Returns accounted for $12,4+3,30 t$ eattle, $10,586,594$ sheep, and $4,200,280$ pigstotals which compare favourably with the figures for 1916. Supplies of home-grown meat for the civil population were accordingly fairly plentiful, and there was no question of any serious shortage such as has been experienced in the Enited Kingdom. In fact, during the Autumn, the Army Anthorities availed themselves to a certain extent of the extra supplies that were being marketed to ereate a temporary reserve of frozen meat, so far as the cold storage accommodation would allow: Two meatless days per week were instituted from March until September inclusive, after which period it was found possible to discontinue this restriction.

"Italy.-During 1917, the quantity imported was greater than in any preeeding year' but the still inereasing demand exceeded the supply, and it may be assumed that Italian herds of eattle deereased during the year, in spite of the fact that the two meatless days per week, instituted in Nay, 1915, are still enforced.

"The fleet of Italian-owned refrigerated steamers is now of some importance, and these vessels are proving of great utility in the importation of the inereased supplies required by the Allied Armies now operating in Italy.

\section{Notes oN V.inious Solrces of Supply.}

"United Kingdom.-On paper, the herds and flocks of this comtry were in a satisfactory position when the us:tal ammal census was taken on 4th June, 1917, by the Board of Agriculture. The number of eattle at that date was $12,381,186$ head compared with $12,451,540$ head in Jume, 1916, a reduction of only 0.5 per cent. from the largest total on record. In the case of sheep the figures were $27,867,244$ in 1917 , against $28,849,65.5$ in $1916-$ a reduction of 3.4 per cent. from one of the best years of the present century.

"Australia.-Weather eonditions continued to be highly favourable in all parts of the Commonwealth, and stock gener- 
ally are in good fettle. Nevertheless, exports of Beef were considerably lighter than was anticipated, disastrous droughts two years previously having materially reduced the herds in Queensland. Intton was shipped in restricted volume because so many graziers, anxious to replenish their flocks, were ready to pay prices for stock beyond the moderate limits imposed upon the freezing works by their contract with the British Government. The Works, however, have taken these operations philosophically, realising that they mean larger supplies of freezers for them in the near future.

"The total export output of beef, mutton and lamb in 1917 from all the Australian Works was 118,540 tons, of which 108,740 tons were beef, and only 9,800 tons mutton and lamb. This meat was all shipped for the United Kingdom, except 5,530 tons. In 1916, the total export was 104,000 tons; in 1915, 132,090 tons; and in $1914,171,200$ tons.

"Storage accommodation had been much increased during 1916 in expectation of a larger export trade, but this extra space was not required in 1917 , partly because of the restricted quantities handled, and partly becanse the supply of tomnage was comparatively well maintained. Several experiments were made in the cutting of frozen carcases, with a view to economieal stowage on board ship; and in the ease of mutton and lamb these proved snceessful to the extent of saving 15 to 30 per cent. of space. In the case of beef, the first experimental shipment has not yet come to hand, thongh its treatment also is well spoken of by those who prepared it. Very much more freight space might have been saved by shipping a larger proportion of boned beef.

"New Zealamd.-The export trade was carried on thronghout the year under the revised contract made with the Imperial Government in October, 1916. Owing to scarcity of tomnage, shipments were considerably smaller in 1917 than in 1916. Fortunately large additions had been made to the storing eapacity of all the leading works in the Dominion, so that there was no real difficulty about holding over stocks in store. Towards the end of the year the large shipments made relieved the position; but the restriction of business throughout the year added considerably to the cost of production.

"Sales of the surplus supplies of lamb were made in London at $9 \frac{1}{2} \mathrm{~d}$. in January and at $10 \mathrm{~d}$. during the remainder of the year, 
but the total yuantity distributed through the nsual trade channels was quite inadequate, the market being continuously understocked.

- The report of the ('ommission appointed to inyuire into the operations of American packers in New Zealand was issued in October. It practically amounted to an indietment of their methods generally, and contained a strong warning against their being permitted by the Government to acyuire any further loold on the trade of the Dominion.

- C'amida.-A further satisfactory development of the export tracle from the Dominion took place last rear. when shipments to the Lnited Kingdom and France amounted to $\$ 5.000$ tons, as compared with 15.200 tons in 1916. and 6.2 $>0$ tons in 1915. A certain proportion of the 1917 total consisted of Lnited states beef railed to ('anadian ports for shipment: nerertheless the purely Canadian trade shers signs of healthy expansion. with many indications of its becoming a wellestablished industry after the present abnormal conditions have disappeared. The latest live stock statisties, published in September last, support the view that the Canadian farmers are making strennons efforts to angment their meat supplies, the number of cattle in 1917 being estimated at 7.920 .940 hearl. as against 6.594 .151 head in 1916-a remarkable increase of 20 per cent. Sheep also increased from 2,022,941 head in 1916 to $2.369 .35 \mathrm{~s}$ head in 1917: but there is still no export of mutton from Canada.

"south Africa-As a promising new source of Empire meat supply, the L'nion of Sonth Africa continues to gain in importance. The pastoral conditions of the comutry are eminently suitable for beef production on a large scale, the existing heris of eattle totalling about,- 000.000 head. Farmers throughont the Inion are increasing their efforts to provide beef of a quality suitable for export: freezing accommodation is being extended as rapidly as war conditions will allow: railway facilities are being improved: and the British fovernment. by providing freight space, and purchasing full cargoes at fair prices, for Army requirements, is lending valuable aid to the new industry.

- Exports last rear amounterl to 22.400 tons, as compared with 7.925 tons in 1916 , and 2,324 tons in 1915 . Of the 1917 total only about 3,200 tons came to England, the balance being shipped to other destinations. The restricted quantities which 
reached the London market from time to time shewed no real improvement in quality or condition. as compared with arrivals in 1916. In these respects good results are hoped for from the Commision which the Lnion forernment is reported to be send. ing to Australia and New Zealand. for the purpose of studring the methods of meat production and preparation followed in those countries. It should be realisel by shippers that althongh high prices were secured in this market for the small consignments which came to hand. beef of the quality recently shipped from south Africa would not be rery acceptable here under normal conditions.

"south America.-The total export of frozen and chilled meat from the various sonth American Republies in 1917 amounted to 540.000 tons as compared with 52-.500 ton in 1916. and 471.250 tons in 1915. With the exception of the Argentine Republic. all the exporting countries increased their output.

*Argentine Republic.-The weather of 1917 mas generally favourable for live stock. e-pecially in the Province of Buenos Aires. which produces of 90 per cent. of the beef exported: the animals improsed greatly in condition. and were in plentiful supply throughout. The results of the live stock census aken in 1914 have only recently been published. and reveal a serions reduction as compared with the ofticial "estimates" isued from time to time. Cattle were returned at 25.566.763 head. and sheep at 43.225 .452 head. as against 29.116 .625 cattle. and $67.211 .7 .5 t$ sheep at the previous census taken in 190 These decreases are somewhat disconcerting. but fortunately the cansss which provoked them. riz.. the great Arought of 1911 12 and 1913 have disappeared: and the favourahlp sawns of the past fer rears appear to hare efrected a quich recorers in the number and quality of the lire stock of the country. narticularly in the case of cattle. This view is borne ont by an otticial census taken in the Prorince of Bnenos Aires the principal centre of the cattle raising industry in 1916. which recorded an increase in cattle of nearly 25 per cent.. the figurreing 11.336,513 head in 1916. as against 9.090.536 hear in 1911. It is generally reckneul that the number of eattle in the Argentine Republic is now about 29.000.000 head. while sheep are estimated to number ahont 5.5000 .000 head.

- The operations of the freezing works were limited by the amount of refrigerated tonnage available. and in come a,.. the work was interfered with by strikes, with the result that the 
year's shipments of frozen and chilled meat, amounting to $37 \pi, 430$ tons, fell short of the previous year's total of 436,400 tons by 13.5 per cent. Four-fifths of the exports were sold to the Allied Governments for Army consmmption, the remainder being reserved for the eivilian trade in the United Kingdom.

-Pastoral prospects are now brighter than they have been for several years past; and, apart from any deficiency in refrigerated tomnage, a much increased export in 1918 should be assured. An export tax, which comes into operation as from 1st January, 1918 , introduces a new element of uneertainty into the market; but the tax is likely to be borne by the seller and not by the ultimate buyer, so long as prices are controlled on this side of the world.

- Uruguay.-The number of eattle in 1916 was estimated at $7,802,000$, as against $8,192,600$ in 1908 , while sheep declined from $26,286,000$ to about $11,473,000$ head. These decreases are attributed to climatic conditions, the severe drought of 1915/16 cansing many deaths. Some reevery was, however, effeeted last year as a result of the more favourable season.

"Shipments from the two freezing works at Monte Video amounted to 72,250 tons, as compared with 43,900 tons in 1916 . With the important new freezing works erected by The Morris Beef Co. at Monte Video in operation, some further increase in exports is looked for in 1918.

"Brazil.-The export trade from Brazil has expanded in a remarkable manner, and that eountry bids fair soon to become one of the most important sources of meat supply. In 1915, the first year of trading, the exports were 8,000 tons; in the following year they increased to 33,130 tons; while last year 66,450 tons of beef were shipped-chiefly to the Continent, for the Italian and French Armies. The beef is small and rery suitable for these eountries, though it would hardly be big enough for the best trade in this market. There are now four freezing establishments in Brazil, with several others in course of construction or in contemplation: and everything points to there being a further expansion in exports during the coming year. The number of eattle in Brazil is estimated at 30,000,000 head, the bulk of which, however, are still of somewhat poor quality.

"Patagonia.-The whole ontput of mutton and lamb from the Patagonian freezing works in 1917 was purchased by the British Govermment. The quality proved to be quite satisfactory. The mutton was reserved for Army use, but small quan- 
tities of lamb were released from time to time for sale to the public through the usual channels. Shipments during the year amounted to 18,700 tons, as compared with 11,986 tous in 1916 , and 7,863 tons in 1915 .

"United States.-The latest returus published by the United States Bureau of Statisties in Jammary, 1918, estimate the number of cattle at present in that country at $66,830,000$ head, an increase of $3,100,000$ (or 4.9 per cent.) over the previous year's total of $63,700,000$ head, and 18.2 per cent. more than the low-water mark in 1913, when only 56,527,000 head were recorded. Sheep were returned at $48,900,000$ head, as compared with $48,500,000$ at the end of 1916 . The figures in respect of cattle indicate that steady progress is being made in replenishing the herds of the Lnited States, which had suffered a steady and serious decline for several years prior to the war. "Exports of refrigerated meat showed further expansion during the year, and amounted in aggregate to 95,430 tons, of which 56,000 tons were shipped to the United Kingdom, 22,350 tons to the Continent, and 17,080 tons railed to Canada (presumably for shipment to Europe) as compared with 80,910 tons in 1916, of which 41,820 tons came to the United Kingdom, and 39,120 tons went to the Continent. So recently as in 1913 the total export was only 437 tons.

"In view of the comparative proximity of the United States to this country, and its active participation in the war, an increased export of meat may be expected from that quarter during the coming rear.

\section{Prospects.}

"The opinion is held almost universally that after" the war there will be a scramble amongst all the big consuming countries of the world and some of the smaller nations which have not previously been importers of meat, for a share in the world's exportable surplus. High prices are anticipated as a consequence of the keen competition to be looked for under such circumstances; and fears are freely expressed that the available supplies will fall far short of the requirements of a Continent which for some years has been reduced to very modest rations, under the stress of war.

"The outlook for supplies is, however, more than hopeful; plenty is almost assured. The producing countries of the world in Australasia, South Ameriea, North America and also South Africa are being favoured with good seasons as a rule, they are 
all well supplied with refrigerating plant, and stock is nowhere scarce. The only problem remaining to be solved is transport, and even that is not by any means unsatisfactory. The tonnage of refrigerated steamers now in existence, nuder the British flag, is as large as at the outbreak of war; and new shipping lines have been started in France and Italy, which bring the world's aggregate of refrigerated tomage into an exceptionally. strong position. If only the available means of transport be utilised to their full eapacity for this their main purpose, there can be little doubt but that the most pressing prospective demands will not go minatisfied for want of the meat nor for lack of ships to bring it to Europe."

\section{I.- Table showing the quantity of Frozen Mutton and Lamb} (in careases) imported into the Inited Kingdom since the trade commenced.

\begin{tabular}{|c|c|c|c|c|c|c|c|c|c|}
\hline \multirow{2}{*}{ Year } & \multicolumn{2}{|c|}{ Australia } & \multicolumn{2}{|c|}{ New Zealand } & \multicolumn{3}{|c|}{ South America } & \multirow{2}{*}{\begin{tabular}{|c|}
$\begin{array}{c}\text { Other } \\
\text { Countries } \\
\text { O K Ports }\end{array}$ \\
\end{tabular}} & \multirow{2}{*}{ Totals } \\
\hline & Londoo & Other Ports & Loadon & Other Ponts & London & Liverpool & Otbet Ports & & \\
\hline $\begin{array}{l}1880 \\
1881 \\
1882 \\
1883 \\
1884 \\
1885 \\
\end{array}$ & $\begin{array}{r}400 \\
17,275 \\
57,256 \\
63,733 \\
111,745 \\
95,051 \\
\end{array}$ & $\begin{array}{l}\bar{z} \\
\bar{z} \\
\end{array}$ & $\begin{array}{r}- \\
8,839 \\
120,893 \\
412,349 \\
492,269 \\
\end{array}$ & $\begin{array}{l}\bar{z} \\
= \\
=\end{array}$ & $\begin{array}{r}\overline{\overline{ }} \\
\overline{\overline{ }} \\
17,165 \\
108,823 \\
190,571 \\
\end{array}$ & $\begin{array}{l}\bar{z} \\
\bar{z} \\
\bar{z}\end{array}$ & $\begin{array}{l}\bar{z} \\
\bar{z} \\
\end{array}$ & $\begin{array}{l}\bar{z} \\
\bar{z}\end{array}$ & $\begin{array}{r}4(x) \mathrm{C} / \mathrm{ce} \\
17,275 \quad " \\
66,095 \quad " \\
201.791 \quad " \\
632.917 \\
777.891 \quad " \\
\end{array}$ \\
\hline $\begin{array}{l}1886 \\
1887 \\
1888 \\
1889 \\
1890 \\
\end{array}$ & $\begin{array}{r}66,960 \\
88,811 \\
112,214 \\
86,547 \\
207,984 \\
\end{array}$ & $\bar{z}$ & $\begin{array}{r}655,888 \\
766,417 \\
939,231 \\
1,068,286 \\
1,533,393 \\
\end{array}$ & $\begin{array}{l}\bar{z} \\
\bar{z}\end{array}$ & $\begin{array}{l}331,245 \\
242,903 \\
169,282 \\
167,936 \\
124,413 \\
\end{array}$ & $\begin{array}{r}103,454 \\
392,963 \\
754,721 \\
842,000 \\
1,07+118 \\
\end{array}$ & $\begin{array}{l}\bar{z} \\
\overline{-}\end{array}$ & $\begin{array}{c}30,000 \mathrm{~F} \\
45,552 \mathrm{~F} \\
\overline{-} \\
10,168 \mathrm{~F}\end{array}$ & $\begin{array}{l}1,187,547 \\
1,542,646 \\
1,975,44 \times \\
2,164,769 \quad " \\
2,948,076 \quad \text { " }\end{array}$ \\
\hline $\begin{array}{l}1891 \\
1892 \\
1893 \\
1894 \\
1895 \\
\end{array}$ & $\begin{array}{l}334,684 \\
449,488 \\
636,917 \\
939,360 \\
969,943 \\
\end{array}$ & $\begin{array}{l}\overline{5}_{2,250} \\
\overline{\overline{3}_{560}} \\
\end{array}$ & $\begin{array}{l}1,894,105 \\
1,505,377 \\
1,821,595 \\
1,947,609 \\
2,412,331 \\
\end{array}$ & $\begin{array}{r}34,2 \overline{228} \\
36,003 \\
10,650 \\
-\end{array}$ & $\begin{array}{l}160,340 \\
166,508 \\
109,808 \\
171,802 \\
142,038 \\
\end{array}$ & $\begin{array}{r}950,797 \\
1,081,353 \\
1,263,915 \\
1,199,585 \\
1,360,968\end{array}$ & $\begin{array}{r}\bar{z} \\
43,428 \\
112,789\end{array}$ & $\begin{array}{l}18,897 \mathrm{~F} \\
17,818 \mathrm{~F} \\
16,425 \mathrm{~F} \\
11,675 \mathrm{~F} \\
19,43 \% \mathrm{~F} \\
\end{array}$ & $\begin{array}{l}3,358,823 \\
3,310,022 \quad " \\
3,884,663 \\
4,324,109 \\
5,053,067 \quad " .\end{array}$ \\
\hline $\begin{array}{l}1896 \\
1897 \\
1898 \\
1899 \\
1900 \\
\end{array}$ & $\begin{array}{r}1,565,360 \\
1,338,964 \\
1,238,653 \\
1,189,563 \\
906,766 \\
\end{array}$ & $\begin{array}{l}77,883 \\
68,453 \\
10,000 \\
15,038 \\
37,158 \\
\end{array}$ & $\begin{array}{l}2,211,895 \\
2,703,845 \\
2,784,101 \\
3,250,100 \\
3,157,060\end{array}$ & $\begin{array}{l}\bar{z} \\
\bar{z}\end{array}$ & $\begin{array}{l}245,573 \\
161,744 \\
201,895 \\
239,703 \\
271,432 \\
\end{array}$ & $\begin{array}{l}1,392,700 \\
1,771,542 \\
1,935,365 \\
1,805,646 \\
1,773,381 \\
\end{array}$ & $\begin{array}{l}154,(0) 7 \\
18 \times, 1 \times 5 \\
260,077 \\
369,369 \\
2 \times 6,024\end{array}$ & $\begin{array}{l}= \\
=\end{array}$ & $\begin{array}{l}5,647,418 \quad " \\
6,23,733 \quad ", \\
6,430,091 \\
6,469,414 \\
6,433,821 \quad "\end{array}$ \\
\hline $\begin{array}{l}1901 \\
1902 \\
1903 \\
1904 \\
1905 \\
\end{array}$ & $\begin{array}{r}1,194,157 \\
648,929 \\
449,090 \\
413,322 \\
1,190,584 \\
\end{array}$ & $\begin{array}{r}32,401 \\
75,368 \\
28,947 \\
37,001 \\
177,854 \\
\end{array}$ & $\begin{array}{l}3,234,119 \\
3,668,061 \\
4,566,257 \\
3,695,088 \\
3,479,757 \\
\end{array}$ & $\begin{array}{r}\overline{\bar{z}} \\
17,503 \\
190,143 \\
224,809 \\
\end{array}$ & \begin{tabular}{|r|}
342,525 \\
411,913 \\
650,004 \\
746,096 \\
$1,102,282$ \\
\end{tabular} & $\begin{array}{l}1,952,625 \\
2,081,128 \\
2,141,469 \\
1,831,149 \\
1,697,3 ; 7 \\
\end{array}$ & $\begin{array}{l}338,955 \\
334,455 \\
326,964 \\
360,456 \\
40,561 \\
\end{array}$ & $\begin{array}{l}- \\
=0 \mathrm{~s} \\
-\mathrm{NA} \\
= \\
\end{array}$ & 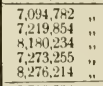 \\
\hline $\begin{array}{l}1906 \\
1907 \\
1908 \\
1909 \\
1910 \\
\end{array}$ & $\begin{array}{l}1,339,677 \\
1,762,047 \\
1,214.753 \\
1,583,928 \\
2,634,274\end{array}$ & $\begin{array}{r}392,651 \\
575,884 \\
616,493 \\
1,094,910 \\
1,585,534 \\
\end{array}$ & $\begin{array}{l}3,818,506 \\
4,353,08 \times \\
3,833,012 \\
4,587,217 \\
4,842,959 \\
\end{array}$ & $\begin{array}{l}329,782 \\
444,279 \\
401,146 \\
447,886 \\
564.515 \\
\end{array}$ & $\begin{array}{r}932,986 \\
1,002,403 \\
1,435,137 \\
1,258,017 \\
1,095,555 \\
\end{array}$ & $\begin{array}{l}1,582.606 \\
1,607,520 \\
1,681,620 \\
1,641,430 \\
1,753,166 \\
\end{array}$ & $\begin{array}{l}403,684 \\
405,346 \\
469,257 \\
453,774 \\
505,041 \\
\end{array}$ & $\begin{array}{l}\overline{ } \\
\bar{z} \\
\overline{-}\end{array}$ & $\begin{array}{r}8,799,8922 \\
10,15 x, 527 \\
9,651,418 \\
11,067.152 \\
12,9 \times 1,044\end{array}$ \\
\hline $\begin{array}{l}1911 \\
1912 \\
1913 \\
1914 \\
1915 \\
\end{array}$ & $\begin{array}{l}2,331,572 \\
1,545,917 \\
2,381,357 \\
2,153567 \\
2,413,183 \\
\end{array}$ & $\begin{array}{l}1,281,707 \\
1,337,562 \\
2,061,169 \\
1,569,263 \\
1,169,728\end{array}$ & $\begin{array}{l}4,513,457 \\
4,839,401 \\
5,092,054 \\
5,304.541 \\
6,146,615 \\
\end{array}$ & $\begin{array}{l}709,038 \\
655,810 \\
581,570 \\
876,643 \\
347.582 \\
\end{array}$ & $\begin{array}{r}1,126,303 \\
1,305,419 \\
865,703 \\
1,038,627 \\
976,092 \\
\end{array}$ & $\begin{array}{l}2,400.959 \\
1,817.556 \\
1.557 .316 \\
1.574,974 \\
1.089 .245 \\
\end{array}$ & $\begin{array}{r}598,347 \\
507,4: 0 \\
397,005 \\
271,224 \\
46,259 \\
\end{array}$ & $\begin{array}{c}\bar{z} \\
\overline{\bar{z}} \\
2.657 \mathrm{v}\end{array}$ & $\begin{array}{l}12,950,3 \times 3 \\
12,1 \times 99,165 \\
12,936,165 \\
12,788,839 \\
12,191,341\end{array}$ \\
\hline 1916 & 566,688 & 105,200 & $4,679,361$ & $72 i 861$ & $1,304,914$ & 959,112 & 47,425 & $\times 2,175^{\circ} A^{3}$ & $8.472 .73 \hbar \ldots$ \\
\hline TOTAI.S & 34.299 .719 & $12,441,0 \times 5$ & $100,339,076$ & $6,599,5: 8$ & $18,817,147$ & $45,075,750$ & $7,2 \times 5.012$ & $254, \times 15$ & $225,112,042 \ldots$ \\
\hline 1917 & available & ulicat & A & $C_{1}$ & . & . & . & . & $7(c$ \\
\hline
\end{tabular}


II.-Table showing numbers of Cattle and Sheep in the United Kingdom in each of the past six years, and importations of Live Stock, lieef, Mutton and Lamb from all sources during 1912$1916:-$

\begin{tabular}{|c|c|c|c|c|c|c|c|c|}
\hline & & & 1917 & 1816 & 1818 & 1814 & 1913 & 1312 \\
\hline \multirow{4}{*}{$\begin{array}{l}\frac{1}{3} \\
\frac{2}{2} \\
\vdots \\
0 \\
\frac{\omega}{E} \\
0 \\
0 \\
x\end{array}$} & OATTLE $\left\{\begin{array}{l}\text { Cows and Heifers } \\
\text { Other Cattle }\end{array}\right.$ & No. & $\begin{array}{l}4,514,553 \\
7,866,633\end{array}$ & $\begin{array}{l}4,499,321 \\
7,452,219\end{array}$ & $\begin{array}{l}4,494,750 \\
7,676,702\end{array}$ & $\begin{array}{l}4,595,129 \\
7,589,377\end{array}$ & $\begin{array}{l}4,317,957 \\
7,618,693\end{array}$ & $\begin{array}{l}4,400,816 \\
7,513,819\end{array}$ \\
\hline & Total $\ldots$ & No. & $12,381,186$ & $12,451,540$ & $12,171,452$ & $12,184,505$ & $11,436,600$ & $11,914,635$ \\
\hline & SHERP $\left\{\begin{array}{l}\text { Breeding Ewes ... } \\
\text { Other Sheep }\end{array}\right.$ & $\begin{array}{c}\text { No. } \\
n\end{array}$ & $\begin{array}{l}11,444,673 \\
16,422,571 \\
\end{array}$ & $\begin{array}{l}11,603,904 \\
17,245,751 \\
\end{array}$ & $\begin{array}{l}11,341,904 \\
16,934,066 \\
\end{array}$ & $\begin{array}{l}11,255,727 \\
16,708,250 \\
\end{array}$ & $\begin{array}{l}11,057,425 \\
16,571,781 \\
\end{array}$ & $\begin{array}{l}11,670,055 \\
17,297,440\end{array}$ \\
\hline & TOTAL .. & No. & $27,867,244$ & $28,849,655$ & $28,275,970$ & $27,963,977$ & $27,6: 29,206$ & $28,967,495$ \\
\hline \multicolumn{9}{|c|}{ It is estamated that $25^{\circ}$. of the Cattle and $A T$. of the Sheep are slaughtered each yeur. } \\
\hline \multirow{4}{*}{ 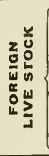 } & 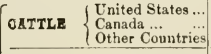 & $\begin{array}{c}\text { No. } \\
. .\end{array}$ & $\bar{z}$ & $\bar{z}$ & $\bar{z}$ & $\overline{\overline{2}} .234$ & $\begin{array}{r}10,093 \\
1,755 \\
2,895 \\
\end{array}$ & $\begin{array}{r}39,987 \\
6,800 \\
2,125 \\
\end{array}$ \\
\hline & Total .. & No. & - & - & - & 2,234 & 14,743 & 48,912 \\
\hline & $\begin{array}{c}\text { SHEEP \& } \\
\text { LAM BS }\end{array}$ & No. & $\overline{-}$ & $\overline{-}$ & $\bar{z}$ & 1,707 & ${ }_{501}$ & $\begin{array}{r}14,237 \\
1.193 \\
\end{array}$ \\
\hline & TOTAL ... & No. & - & - & - & 1,707 & 501 & 15,430 \\
\hline \multirow{2}{*}{ 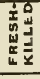 } & $\{$ BEEF $\ldots$ Continer:t, \&c.... & Cwts. & - & 45 & 2,093 & 5,252 & 2,426 & 13,775 \\
\hline & MUTTON Continent, \&c. ... & Cwts. & - & 16,511 & 48,941 & 150,445 & 126,033 & 162,820 \\
\hline \multirow[t]{2}{*}{$\begin{array}{l}\frac{0}{2} \\
\frac{a}{3} \\
\frac{3}{3} \\
0\end{array}$} & $\left\{\begin{array}{l}\text { BEEF } \ldots\left\{\begin{array}{l}\text { United States ... } \\
\text { Canada ... } \\
\text { Argentina } \\
\text { Uruguay } \\
\text { Brazil } \ldots \\
\text { Other Countries }\end{array} \ldots\right. \\
\end{array}\right.$ & $\begin{array}{c}\text { Cकts. } \\
" 1 \\
" 1 \\
" 1 \\
-" .\end{array}$ & \multirow{7}{*}{ 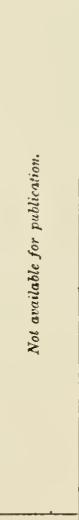 } & $\begin{array}{r}388,611 \\
- \\
1,275,647 \\
171,117 \\
36,715 \\
- \\
\end{array}$ & $\begin{array}{r}608,908 \\
e x t .41,820 \\
1,702,180 \\
289,113 \\
18,314 \\
25 \\
\end{array}$ & $\begin{array}{r}11,663 \\
8 \\
4,649,718 \\
160,412 \\
- \\
\end{array}$ & $\begin{array}{r}1,462 \\
6,555 \\
5,216,022 \\
31,982 \\
- \\
-\end{array}$ & $\begin{array}{r}6,111 \\
11,650 \\
3,879,5 \times 0 \\
- \\
\overline{1}, 280 \\
\end{array}$ \\
\hline & TOTAL & Cwits. & & $1,872,090$ & $2,660,366$ & $4,821,801$ & $5,256,021$ & $3,898,621$ \\
\hline \multirow{6}{*}{ 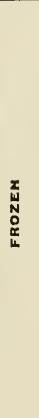 } & 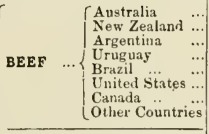 & $\begin{array}{c}\text { Qrs. } \\
" 1 \\
" 1 \\
" 1 \\
" 1 \\
" 1\end{array}$ & & $\begin{array}{r}591,998 \\
639,684 \\
1,678,583 \\
37,942 \\
44,236 \\
288,346 \\
38,887 \\
26,512\end{array}$ & $\begin{array}{r}1,143,779 \\
4 \times 2,232 \\
2,154,254 \\
46,817 \\
27,1145 \\
194,280 \\
20,652 \\
44,106\end{array}$ & $\begin{array}{r}1,236,4606 \\
321,7 \times 4 \\
852,612 \\
456,256 \\
-7,307 \\
-700 \\
7 .\end{array}$ & $\begin{array}{c}1,084832 \\
126.750 \\
1,060,312 \\
345,030 \\
= \\
= \\
=\end{array}$ & $\begin{array}{r}732,8,34 \\
157,850 \\
1,580,644 \\
212,745 \\
= \\
\overline{12,674}\end{array}$ \\
\hline & TOTAL & Qrs. & & $3,346,188$ & $4,113,265$ & $2.923,125$ & 2.616 .924 & $2,696,747$ \\
\hline & MUTTON $\begin{cases}\text { Australia } & \ldots \\
\text { New Zealand } & . . \\
\text { Argentina } & \ldots \\
\text { Uruguay } & \ldots \\
\text { Patagonia } & \ldots \\
\text { Other Countries }\end{cases}$ & $\begin{array}{c}\mathrm{C} / \mathrm{cs} \\
" \\
" 1 \\
" 1 \\
" . \\
\end{array}$ & & $\begin{array}{r}270,959 \\
2,410,126 \\
766,344 \\
48,768 \\
638,655 \\
57,446 \\
\end{array}$ & $\begin{array}{r}2,179,952 \\
2,830,233 \\
762,085 \\
117,031 \\
571,410 \\
2,657 \\
\end{array}$ & $\begin{array}{r}2.088,222 \\
2,616,6550 \\
1,4 \times 9,812 \\
70,501 \\
481,616 \\
= \\
\end{array}$ & $\begin{array}{c}2,9 \times 3.751 \\
2,249.705 \\
1,361,993 \\
329,967 \\
452,038 \\
-\end{array}$ & $\begin{array}{r}1,643,790 \\
2,315,4,13 \\
2,227,374 \\
269,7152 \\
220,227 \\
\end{array}$ \\
\hline & Total $\ldots$ & $\mathrm{C} / \mathrm{cs}$. & & $4,192,298$ & 6.463 .368 & $6,716,801$ & $7,377.454$ & $6,676,6045$ \\
\hline & 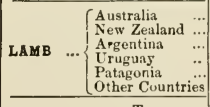 & $\begin{array}{c}\mathrm{C} / \mathrm{cs} . \\
" \\
" 1 \\
" \prime \\
\end{array}$ & & $\begin{array}{r}400,9299 \\
2.997,056 \\
44,174 \\
2,930 \\
410,5 \times 0 \\
24,729 \\
\end{array}$ & $\begin{array}{r}1,402,959 \\
3,663.964 \\
313,796 \\
19,664 \\
327,610 \\
- \\
\end{array}$ & $\begin{array}{r}1,634,609 \\
3,564,534 \\
599,044 \\
2,110 \\
241,742 \\
= \\
\end{array}$ & $\begin{array}{r}1.458 .766 \\
3.423 .919 \\
391.537 \\
7.547 \\
276,892 \\
- \\
\end{array}$ & $\begin{array}{r}1,239,6 \times 9 \\
3,179,838 \\
712,0 * 5 \\
9,038 \\
191,929 \\
- \\
\end{array}$ \\
\hline & Total & $\mathrm{C} / \mathrm{cs}$. & & $4,280,438$ & $5,727.993$ & 6.042 .038 & $5.558,711$ & $5,332,559$ \\
\hline
\end{tabular}


III.-Summary of supplies of Beef, Mutton and Lamb showing total estimated weight available for consumption in the United Kingdom in each of the past six years:-

\begin{tabular}{|c|c|c|c|c|c|c|c|c|c|c|}
\hline & & & & & 1917 & 1916 & 1918 & 1914 & 1913 & 1912 \\
\hline \multirow[t]{2}{*}{$\begin{array}{l}\text { HOME- } \\
\text { OROWN }\end{array}$} & $\left\{\begin{array}{l}\text { Beef } \\
\text { Mutton }\end{array}\right.$ & $\dddot{*}$ Lamb & $\ldots$ & Tons & $\begin{array}{l}787,500 \\
297,500 \\
\end{array}$ & $\begin{array}{l}833,810 \\
363,100\end{array}$ & $\begin{array}{l}815,050 \\
302,960\end{array}$ & $\begin{array}{l}815,970 \\
299,590\end{array}$ & $\begin{array}{l}799,300 \\
296,000\end{array}$ & $\begin{array}{l}797,850 \\
310,250\end{array}$ \\
\hline & & TOTAL & $\ldots$ & $"$ & $\{1,085,000$ & $1,142,910$ & $1,118,010$ & $1,115,560$ & $1,095,300$ & $1,108,100$ \\
\hline \multicolumn{3}{|c|}{ 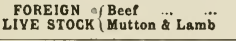 } & $\cdots$ & $"$ & $\overline{-}$ & $\overline{-}$ & $\overline{-}$ & $\begin{array}{r}718 \\
45 \\
\end{array}$ & $\begin{array}{r}4,739 \\
13\end{array}$ & $\begin{array}{r}15,721 \\
113\end{array}$ \\
\hline \multicolumn{3}{|r|}{ TIITAL } & $\ldots$ & ." & - & - & - & 763 & $x, 752$ & 16,131 \\
\hline \multirow[t]{2}{*}{$\begin{array}{c}\text { FRESH } \\
\text { KILLED, ctc. }\end{array}$} & $\left\{\begin{array}{l}\text { Beef } \\
\text { Mutton }\end{array}\right.$ & $\dddot{a}$ Lamb & $\therefore$ & $"$ & $\overline{-}$ & 825 & $\begin{array}{r}105 \\
2.417 \\
\end{array}$ & $\begin{array}{r}963 \\
7,526 \\
\end{array}$ & $\begin{array}{r}12 l \\
6.302 \\
\end{array}$ & $\begin{array}{r}6 s ; \\
8,1+1 \\
\end{array}$ \\
\hline & & TotAL & .. & . & - & 827 & 2,532 & 7,749 & $6.1 \geq 3$ & 8,929 \\
\hline \multirow[t]{2}{*}{ CHILLED } & $\begin{array}{l}\text { Beef } \\
\text { Mutton }\end{array}$ & $\begin{array}{ll}. . & \cdots \\
\cdots & \cdots\end{array}$ & $\cdots$ & ". & & ${ }^{93,605}$ & 133,018 & $2+1,1990$ & 262,901 & ${ }^{191,731}$ \\
\hline & & TOTAL &.. & . & & 1193,605 & $\pm 133,025$ & $\$ 211,090$ & $+262,401$ & 194,931 \\
\hline \multirow[t]{4}{*}{ FROZEN } & $\left\{\begin{array}{l}\text { Beef } \\
\text { Mutton }\end{array}\right.$ & a Lamb & $\cdots$ & $"$ & & $\begin{array}{l}259,203 \\
151,003\end{array}$ & $\begin{array}{l}296,961, \\
232,946\end{array}$ & $\begin{array}{l}2010,475 \\
252, \pm 62\end{array}$ & $\begin{array}{l}197,243 \\
260,213\end{array}$ & $\begin{array}{l}205,117 \\
212,931\end{array}$ \\
\hline & & Total. & ... & ." & $\cdot 550,000$ & $\| \pm t^{\prime \prime}, 206$ & $\pm 529,907$ & $\$+53,3,3\rangle$ & $+4: 7.456$ & $\pm 14,015$ \\
\hline & $\begin{array}{l}\text { cotal of } \mathrm{Be} \\
\text { cotal of } \mathrm{M}\end{array}$ & $\begin{array}{l}\text { Beef } \\
\text { Mutton Lam }\end{array}$ & & $\ddot{~}$ & & $\begin{array}{r}1,156,600 \\
4,20,925\end{array}$ & $\begin{array}{r}1,245,134 \\
535,353\end{array}$ & $\begin{array}{r}1,255,916 \\
559,023 \\
\end{array}$ & $\begin{array}{r}1,2614,2114 \\
562,325 \\
\end{array}$ & $\begin{array}{r}1,214,3177 \\
561,735 \\
\end{array}$ \\
\hline & RAND TO & OTAL ... & $\ldots$ & ." & $1,635,000$ & $t, 677,547$ & $1,753,4 s 7$ & $1,515,5,39$ & $1,426,732$ & $1,776,042$ \\
\hline
\end{tabular}

If Allowance made for reduced condition of cattle slaughtered.

* Including chilled beef.

II Deduct 9,437 tons re-exported to France and other countries.

$\ddagger$ Deduct 20,980 tons re-exported to France, Italy, and other countries.

$\S$ Deduct 35,407 tons re-exported to the United States, France and other countries.

$\dagger$ Deduct 6,644 tons re-exported to the United States. 


\section{AUSTRALIA.}

At the present time in Australia, there are 10,500,000 cattle, and $80,000,000$ sheep, and in 1891 there were $11,522,000$ cattle, and 103,260,000 sheep, but droughts, tick, red water, and harassing legislation, have brought the numbers down to the present level. It may be taken, however, for granted, that given the State politicians do not persist in their antagonism to the stock owners, the number of stock in Australia can easily be increased very largely. In the case of eattle, this is particularly so, because not many men are required to handle a cattle station, whereas the amount of labour required on a sheep property is large.

Australia is a vast country, with magnificent grasses for stock, and with a good supply of labour would be hard to beat by any country in the world. The State ownership of railways is a drawback, however, as under this system, unless continual British loans are fortheoming, railway enterprise in opening up new country is stagnant. Again, democratic governments never think of constructing railways unless there are sufficient votes along the proposed line to encourage them to do so. 'Tis votes that count all the time under State ownership of railways. Nearly $£ 500,000$ per annum is given the highly-paid railway and tramway employees in New Sonth Wales alone, in the shape of free passes and concessions. This is passed on to the producer in higher freights. Another drawback is that it is almost impossible to get Government employees to take care of live stock, and they consequently depreciate enormously between their fattening grounds and the meat works on the sea-board. The Anstralian Railways are years behind the times in the matter of refrigerated waggons, and to all appearance nothing will wake them to the necessity of equipping their systems with means of bringing meat down to the seaboard dead, rather than alive, also to the importance of making country life more pleasant by transferring perishable produce to the outback towns in refrigerater wagons as is done in Canada and America.

With the continued improvements in refrigerating machinery, the chances of the chilled beef trade between Australia and the United Kingdom become more promising.

The chilled beef industry stimulates the bringing to a high degree of excellence the cattle of the country from which the shipments are made, for the primest beef is required for chilled 
exports. C'hilled beef enter's a high-class retail trate, where the demand is more regular and prices higher than for frozen beef. The chilling process does far more justice to good meat than does freezing, and it is difficult to avoid holding the view that the great bulk of the supplies of refrigerated beef for Great Britain in the future will ultimately be carried at a chilling temperature.

The largest amount of frozen meat ever sent away from Australia was in 1914-15. In that year five million carcases of mutton and lamb, and over two million quarters of beef were exported: it will be many years before that record is beaten.

The constantly recurring labour troubles are alone sutlicient to landicap the industry. The big meat works of Queeusland from whence almost all the beef is exported, are continually blought to a standstill by the despicable behaviour of the unionists; I was going to say "The Workers," but that is a mismomer, they are not workers and have little or no intention of being so. Backed up in all their demands by the present Government in that state, they imagine they have only to go far enough and the private companies will drop out and the Govermment take over the works. Then when that comes about, they believe they can loaf as much as they like, receive fictitious wages, and the loss will be made good by taxation and British loans. Such is the pitiable condition to-day of one of the finest and largest sources for a hig beef supply, therefore one is not at all sanguine of any immediate big development from Queensland in the beef line. A normal export of from one and a half to two million quarter's can be looked for at present and in the near future, but a big change in "Labour' s" attitude must take place before any large increase can be expected. Queensland cattle kill at about an average of $640 \mathrm{lbs}$. dead weight at the meat works.

Great developments should take place in Western Australia in regard to eattle supply. There is an enomous area of excellent eattle country, and with freezing works at Wrndham and other ports, a big supply of frozen beef can be depended upon. This supply will be a fortnight nearer the world's markets than that of the Eastern sea-board, and necessarily the freight should be lower. The whole thing depends on the Government; with just legislation, security of tenure, and decent labour, there is nothing to prevent Western Australia rivalling, and even beatinx, Queensland in her beef output. As regarels mutton-sheep and lambs-everything points to a larger supply than formerly. 


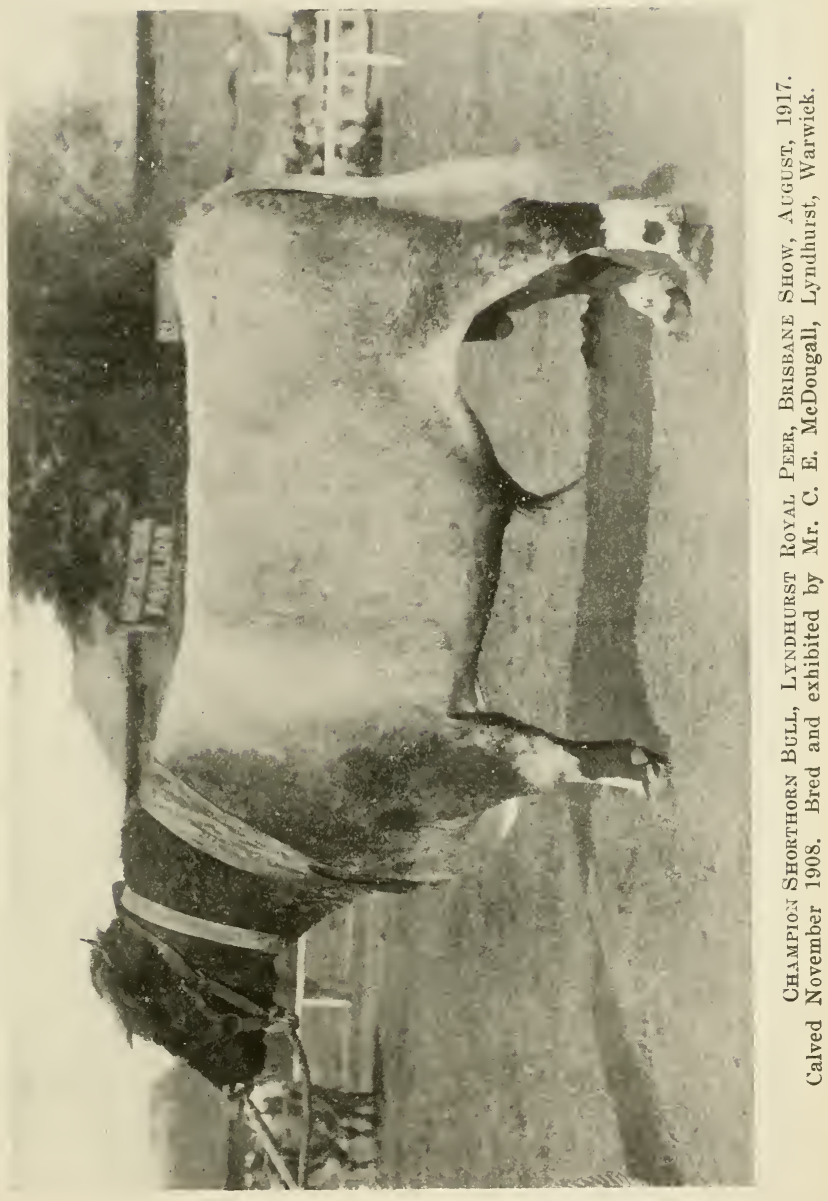


Cross breeding has been gone into very extensively, and many men are now breeding for export sheep and lambs. Under derent conditions and with a Government with brains sufficient to eneomrage the men on the land to inerease and multiply their flocks and herds, Australia alone should easily be able to supply Great Britain with all the mutton she may require. Recently the Hon. D. J. Gordon, of Adelaide, read a paper before an Interstate conference of meat exporters in Sydney on the Live Stock Industry of Australia. This was reprinted in The Pastoral Reviex, and as it gives the views of breeder's, I reprint it here with confidence.

\section{CALSES OF SHORTAGE IN LIVE STOCK AND SUGGESTED REMEDIES.}

There have been many contributory factors to the want of vitality in Australia's leading industry, and the serious shortage in live stock as disclosed in the latest statistics. With a view to investigating the eauses I sent eireulars to a number of leading stockowners, and asked for replies to the following questions.

The smmmary of the replies received is of special importance, since it represents the views expressed by men of experience who are in the business:-

1. What are the main causes of the shortage of sheep and cattle in Anstralia?

Dronghts at intervals, and the exceptionally bad season of 1914. General want of confidence in trend of legislation, overstocking, and destruetion of natural herbage. Breaking up large estates and dispersal of flocks and herds-often stud sheep and eattle. Failure of small settlers to keep stock. Inadequate transport facilities, and neglect of State-owned railwar managers to provide facilities similar to Argentina. United States, and Canada. Big saving of stock would be possible even in worst dronghts if railways were adequate and the management responsive. Incrasing burdens of taxation and general politieal vendetta against live stock industry. Demands of labour unions and harassing awards. cansing inerease in eost of produetion and diffienlty of working mus. Rabbits and wild dogs.

(The consensus of opinion puts drought first, then dispersal of lig fineks to meet lemand of closer settlement: third, legislation and taxation; and then insufficient railway systems.)

2. What are the best methods to adopt to build up the flocks and herds? 


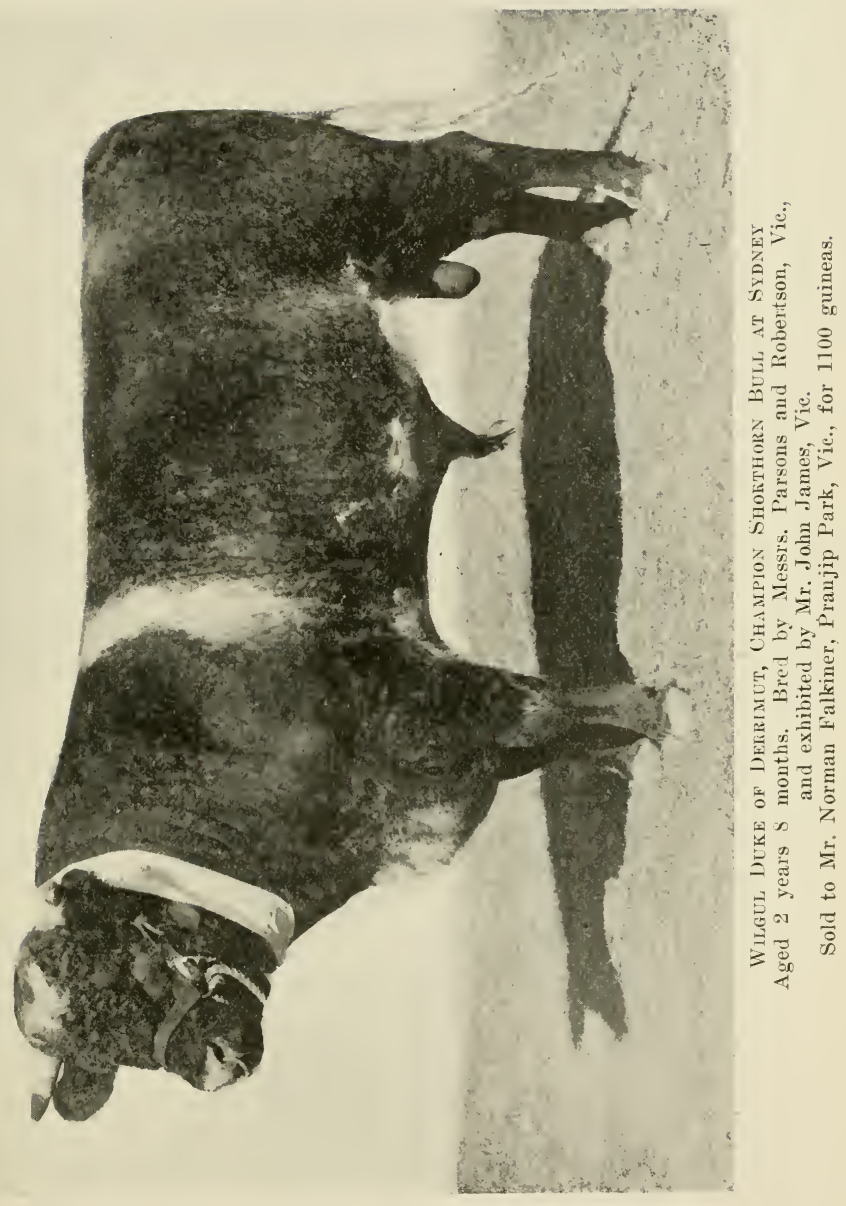


A political truce and fair treatment to stockowners. Link up railway systems and improve same. Abolish breaks of gauge and make railways responsible for damage to stock. Educate small settler's to keep sheep and cattle. Encourage studbreeder's. Remove embargoes and abolish restrictive legislation, which prevents stock passing from State to State. Cultivate grasses and fockder crops for stock and carry reserve supplies against dry seasons. Offer every inducement to secure occupation of outside comtry. Systematic campaign against rabbits and wild dogs. Security of tenure. Increased water supplies.

3. Is it possible to increase the live stock beyond the highest point yet reached in Anstralia, and if so, how?

Not muless outside country and central and north Australia can be opened up by railways and stocked. By farmers earrying small flocks and a few head of cattle. One correspondent advocates a "campaign of education" amongst small settlers.

(Several authorities doubt if the highest water mark will be reached for very many years owing to the dispersal of big flocks and herds; others state that irrigated lands along the Murray and higher prices for meat will encourage breeding up.)

4. In what direction do you look for an expansion of the pastoral industry?

Several correspondents take the view that there is little prospect of expansion in face of growing taxation, industrial unrest, rising wages, and inefficient labour. Other's state that any growth will depend upon successful oceupation of central and northern Australia, growth of confidence, and removal of restrictions. If meat and wool prices remain relatively high they may restore vitality to a languishing industry. One correspondent says: "The industry requires large reserves of capital, and men who can command capital are being driven out of the business." Increased liberal land laws are advocated.

5. Can the sheep and cattle of Australia be improved on the meat side, and if so, how?

Introduction of better bulls from England, especially on "early maturing side," is strongly advocated. Most correspondents contrast the prices paid for stud stock in England by breeders in the Argentine Republic with the lack of enterprise on the part of Australians in keeping $u p$ a standard. 


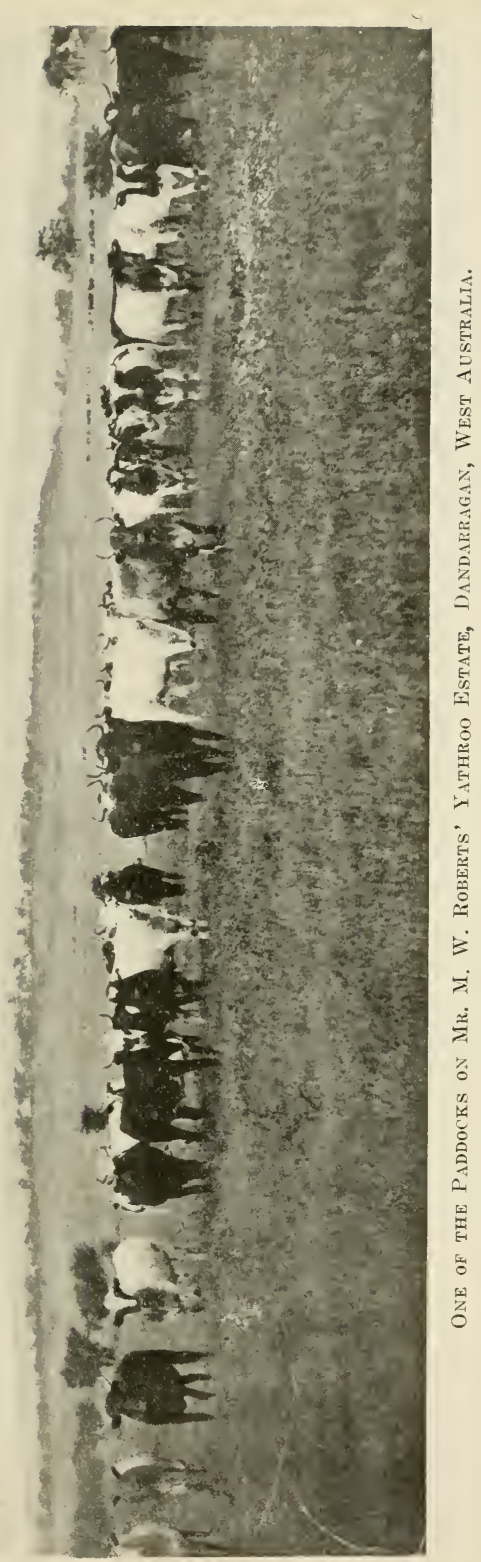


(There is a consensus of opinion that both eattle and sheep can be improved on the meat side with all-round advantage. For export meat trade crossbreeding of sheep is recommended.)

6. What improvements do you recommend in the carriage of live stock on the railways?

Railway management in almost all the States is strongly condemned. One well-informed correspondent, with exceptional experience, says: "The whole system of carriage of stock on railways requires remodelling. State railways should be made 'Common Carriers,' and be responsible. An expert should be imported on behalf of all the States-preferably from Argentina-to revise the whole system. Stock should be watered on long distance runs, and stock trains shoud run to schedule time." Other suggestions are:-Quicker transit, better trucks and loading, more eare by engine drivers, resting depots on long journeys for water and feed, stock trains fitted with air brakes.

7. Can the pastoral industry be encouraged by better land laws; if so, in what direction?

Security of tenure and full compensation for improvements. Liberal land laws and reduction of taxation for purely stock country, and exemption from Federal land tax of outside leases.

8. Do you look for increase in sheep and cattle from Murray River reclaimed lands and from eloser settlement areas?

Only to limited extent unless prices warrant intense culture and hand feeding.

9. Do the cattle and sheep of Australia compare favourably on the meat side with the live stock of other meat-exporting countries?

One correspondent who has visited Argentina writes:- "The cattle do not eompare favourably. The average dead weight beast from Queensland is much less than the Argentine average." A gentleman of many years' practical expericnce in the meat trade of Sonth America says:- "Argentine breeders are always importing stud stock to keej up the standard. There is room for improvement in Australian eattle and better methods of droving -less stockwhip and rough handling - and better methods of dressing are essential in respect to mutton and beef intended for export. Australian sheep are splendid, especially Merinos, on the wool side, but bigger carcases are needed for export." 


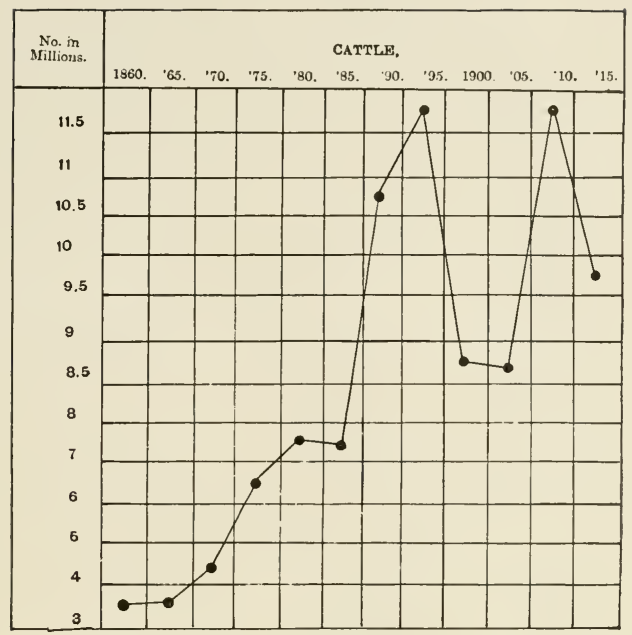

Note the rapid recovery from the 1902 drought and the decline following the good seasons which ended in 1913.14.

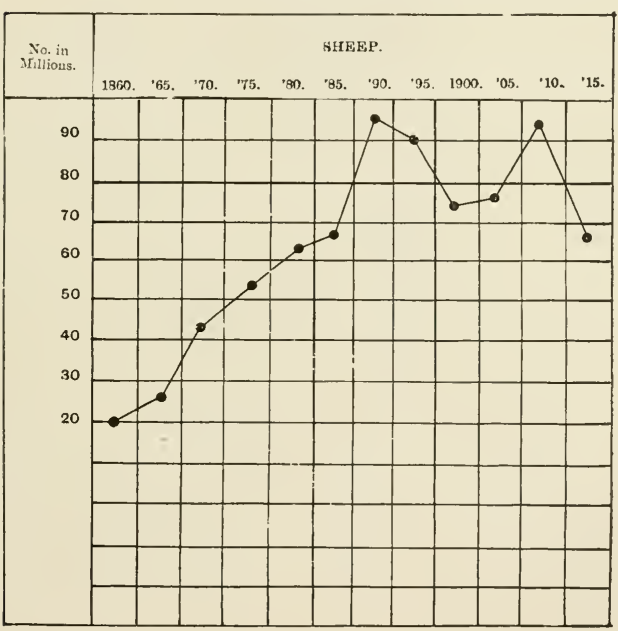



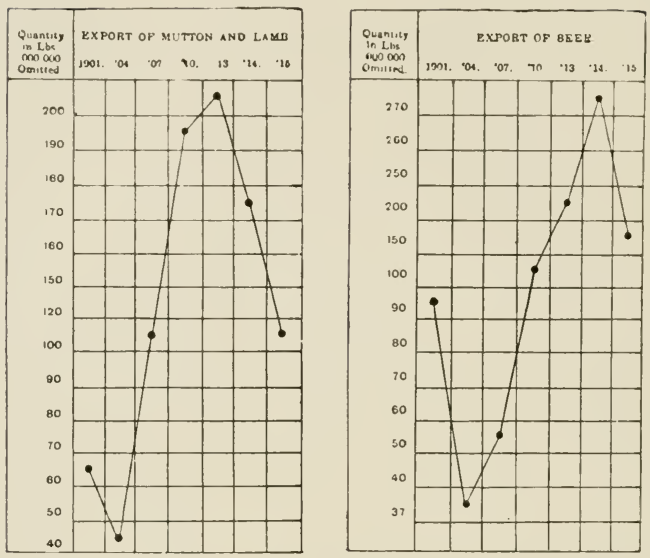

Graphs illustrating Australian Meat Exports from 1901-1915

A leading breeder with experience of the "inside" and "ontside" country, who is specially eompetent to take a broad view of the general situation, writes:-"After looking into your questions I think it all comes back to the lack of confidence that has been firmly established in the minds of those who hold land of any description, that the trend of legislation is to 'kill' rather' than foster the development of the pastoral industry. We are prepared to face droughts, dingoes, and rabbits, as we know something about them and how best to fight them, and we have confidence in ourselves, but they are as nothing compared with the uncertainty of land legislation. The man with eapital who would be prepared to face all the risks and develop and improve his holding stands down and gives way to the speculator, who only holds to get out at the first favorable opportunity. This class of pastoralist is no good for developing country or improving stock. The State could do better without him. The practical man who has the means looks to the future, and providing he conld feel confident of being undisturbed by his landlord, would be ready to tackle all the other odds against him. Rabbits, of course, have killed much or nearly all the drought-resisting stock fodders or plants, and a great portion of southern pas- 
toral Australia will never again be capable of carrying the same quantity of stock. There is much of Australia that ean be settled and developed, but legislation must restore confidence, which has been so sadly shaken that I question whether we will ever again see private enterprise as enthusiastic as in the past. Certainly not till railways are extended, with branch feeder's, will the out-back country be taken up and settled. The studbreeder in the inside country and the pastoralist out-back can successfully fight and withstand droughts and keep vermin within bounds, but the legislator can kill the freeholder and the Crown lessee by a stroke of the legislative pen. And he is doing it, and that spells national disaster."

\section{Chimatic Control of Production.}

Mr. Griffith Taylor, B.Sc., B.E. (Physiographer to the Commonwealth Meteorological Bureau), recently issued a pamphlet under the title "The Climatic Control of Australian Production." He has made "an attempt to gange the potential wealth of the Commonwealth," and certainly that is one of the first steps to take to promote rural expansion. (Here Mr. Gordon gives some summarised extracts from Mrr. Taylor's deductions, and goes on to say ) :-

It would appear from Mr. Taylor's scientific deductions that something more than natural climatic conditions is required to enable the Commonwealth to carry with safety an increasing number of eattle and sheep. The locking of the rivers, the extension of irrigation, a greater use of artesian water supplies, the cultivation of grasses and fodder crops will in time increase the carrying capacity of the country. In this comnection it is worthy of note that during the period that New Zealand was developing its meat export trade, and the population was growing, live stock steadily increased in numbers. Up to the present time Australian live stock owners have given little attention to the growing of feed supplies, while stall feeding in shelter sheds, though shown by experiments to be profitable, is not practised to any appreciable extent. It was Charles Dickens who once remarked at an agricultural clinner that "the field which paid the farmer best to eultivate was the one within the ring fence of his own skull." That statement contains a more important truth to-day than it did in the time of the great novelist. Science is conspicuously aiding the tiller of the soil who places himself in a position to be assisted. Improved ocean transit has hrought 
the produeer in Australia and the consumer in the eentres of population in Europe eloser together, and the refrigerating chamber is opening 11 p almost nnlimited opportunities for the expansion of trade. The remarkable sueeess which attended experiments made in New Zealand in the eighties in the shipment to England of frozen meat eompelled Anstralian breeder's to look askanee at the "boiling down" works whieh were employed for the purpose of dealing with surplus stoek in times of plenty, and relieving the pressure when droughts eame. With a threatened seareity of feed and water before them, pastoralists were sometimes forced to sacrifice their stoek in a flooded market. Sheep used to be killed for the sake of the skins, and the earcases either left to rot on the ground or sold for a few pence per head to the owner of the nearest boiling down works and turned into tallow. The advent of the freezing process and the refrigerating ehamber in steamers altered all this, and the day of the "boiling down" works passed away never to return.

\section{Reconstrection ind Expinsion.}

A eritical period has been reached in the business of raising live stock and in the export of meat, and the vital question is: How can the drift be eheeked and the industry plaeed mpon a firm foundation? The foregoing review and opinions expressed by praetieal men show clearly enough that while climatic eonditions impose distinct limitations, there are other explanations for the stagnation in the industry and the want of confidenee whieh is eausing owners to eurtail operations, and preventing others from taking up country and stoeking it. The pastoral occupation of the ontside conntry is of fundamental importanee to Anstralia. It is the only way to develop natural resources, prople an empty eontinent, keep the factories of the Commonwealth open, and provide employment and eheek the fatal preponderanee of the metropolitan population. In no other way can waste places be made productive. Br increased production alone will it be poswible to meet growing national and private obligations. Australian manufaeturers depend wholly on home markets, and are not likely to beeome exporters. They must look to the stoekowner, graingrower, and dairyman for orders, and similarly the earning nower of State-owned railways and Statecontrolled harbours and ports will fluctuate with the varying fortunes of the primary produeers.

Is it tno mueh. then, to ask that the Parliaments of the Commonwealth and States shall eall a halt to their more or less 


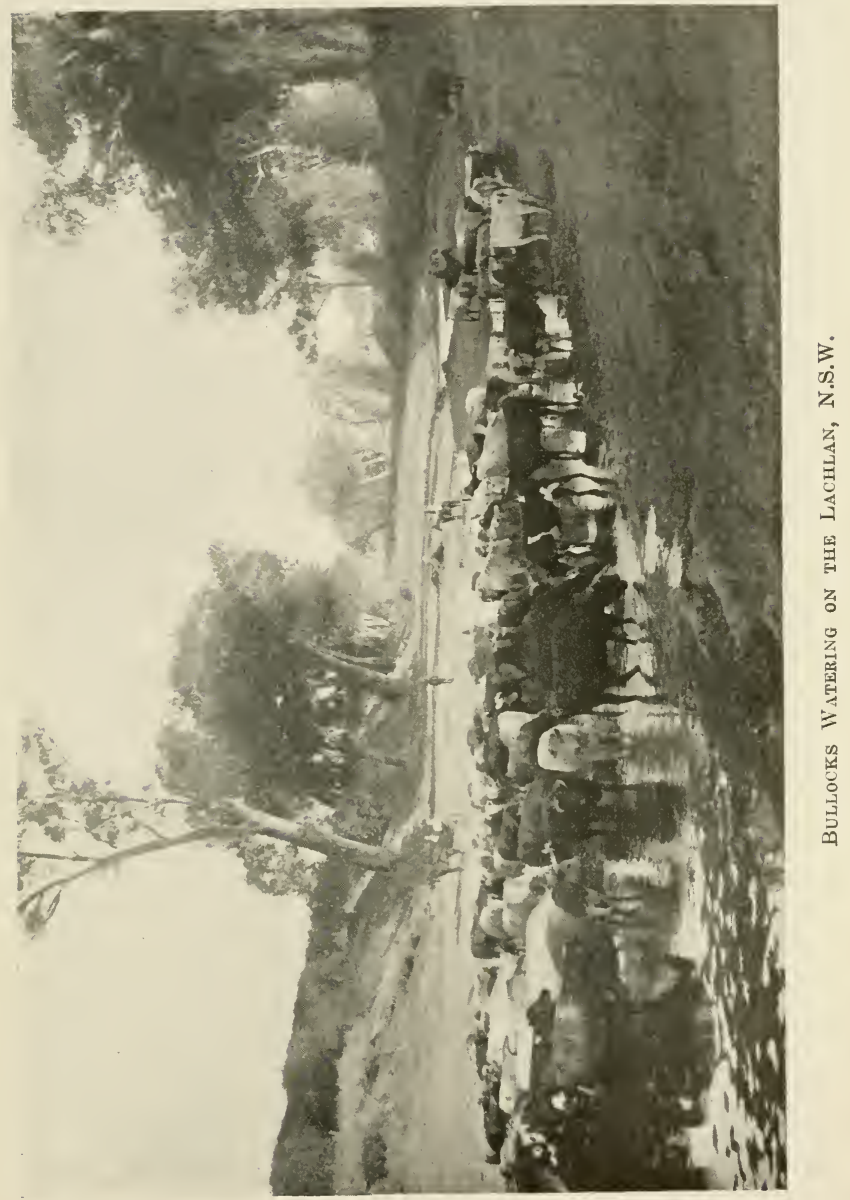


relentless pursuit of the man on the land, and that wiser commsels shall prevail to the end that methods may be employed to restore vitality to languishing rural industries? Anstralia should be able to provide a eheap meat supply for its own people, and build up a larger and more prosperous oversea trade in wool, meat, skins, and hides, but before this can be aceomplished the growing burden of taxation must be lightened or better distributed, ant the paramount importance of the live stock business generally recognised.

A serious menace to which special attention deserves to be drawn is the dispersal of high-class stud flocks and herds, upon which foundation stock-raising has been built and must be maintaine: Without that foundation there ean be no substantial growth. On the contrary, flocks and herds will deteriorate. Sume States are noted for a special type of sheep, and it is from the pure studs that drafts are continually drawn to maintain the great wool trade and the growing meat export business. These "types" can only be produced and kept to standard on good inside country, but the imperative demands of two departments of taxation-Federal and State-make the bisiness of studbreeding a doubtful proposition. Instead of stud flocks and herds increasing they are decreasing, and that factor in relation to Anstralia 's hitherto leading industry ean neither be disputed nor discounted. It represents a danger signal.

In some countries private railway companies offer redneed rates for the carriage of stud animals as an encouragement to breeding which will bring business to the railways. The Stateowned railwars of Australia charge more for stud stocksometimes as much as ten times more than ordinary rates!

In this and other respects there is much that railway managers could do to encourage live stock raising. Owners and agents are unanimous that stock trains should be fitted with air brakes, rum to schedule time, and that provision should be made for watering animals on long distance runs. State Governments might well combine to send a first-class man (not a Government official) on a world tour to inquire into varions systems of earrying live stock, or import an expert to revise our inadequate system. The pastoralist is the best customer the railway departments have, and it will pay to respond to his require. ments and help him to extend his activities and send more produce over the railways.

The extension of railways into central and northern Australia, the gradual elimination of varying ganges, conservation of 
surface waters, and the multiplication of artesian bores are Governmental activities calling for prompt attention as being among the means of giving much-needed vitality to the live stock industry. There is also a distinet eall for an educational carmpaign, more particularly among small settlers, concerning the advantages of keeping stock, the best breeds for given localities, and the profits to be derived from feeding and sheltering stock. The various agricultural departments are singularly weak on the stock side, and little or nothing is being done in an educational way to conduct experiments or carry conviction to the stockowner.

Restore confidence among the men engaged in the industry, and those who would willingly enter the business, and there will be no hesitation in even rivalling the purchases of breeders in the Argentine of high-class stud cattle in England, and the introduction of strains that will improve sheep on the meat side. It was the studbreeder who added several pounds of wool per fleece and produced a wool of mnequalled quality, and the same skill is available and raiting to be utilised on the meat side. That there is the same pioneer spirit of adventure and power of endurance available to make conquests in remote parts of Anstralia has been proved beyond all doubt by young Australians in the great war. Given the opportunity, they will prove worthy sons of the men who have made Australia. The stuff of which pioneers were made is still with us.

In the matter of taxation it must be admitted that a Federal graduated land and income tax on the top of State and local imposts represents a crushing burden to those engaged in woolgrowing and meat-raising. Specific cases have been given to me where two-thirds of income goes in taxation! It has taken the whole of the wool elip of one pastoralist for two years in succession to meet the demands of the tax collector, and stock had to be sold to meet working expenses. One correspondent writes:-_Leaseholder's are now taxed as well as the freeholders, and the extraordinary assessments put on leaseholds is reducing their values enormously. One leasehold of 248 miles, 120 miles from a railway, was assessed at the commencement of a 42 years' lease at $\$ 10,000$ unimproved value. It should not have been worth $£ 1000$; vet with 29 years to run, it has been assessed at $£ 7790$. Four years ago, $£ 12,000$ was given for it, with 8000 sheep and nearly $£ 5000$ of improvements ; $£ 3000$ worth more of improvements were put on before the assessment. Such assessments will make men hesitate to take up leaseholds. Men will 
take big risks for fair dividends, but when they are to be taxed heavily on returns made in good ycars, and get no allowance in bad years, they are not likely to put their money into industries which are so viciously attacked by our Legislatures."

There is not only the problem of reconstruction to be faced, but the greater problem of the expansion of the live stock industry. The practical question is how best to meet this national obligation. It is not a political question-certainly not a party one, since every section of the community will be vitally atfected by the fluctuating fortunes of rural producers. It is an economic problem of first-class importance-a national enterprise which transcends all political and other considerations.

There are at least eight essentials before the live stock industry of Australia can be reconstructed and vigorous growth made possible:-(1) A better appreciation on the part of legislators of the requirements of the industry and the difficulties of successfully occupying the interior of the continent, (2) special encouragement of stud breeding. (3) increasing transportation facilities, (4) revision of taxation and charges borne by the industry in order to prevent an undue pressure causing a decrease in production, (5) campaign of education to encourage small flocks and herds, (6) experiments in closer settled areas in feeding, (7) removal of shipping restrictions and harassing regulations, and ( 8 ) vigorous methods to deal with pests and vermin.

An attempt has been made in the aceompanying diagram to illustrate the scope of investigation and reform necessary to place the industry on a practical and profitable basis.

All this means national organisation, and national organisation is only a convenient term for expressing the highest form of State co-operation with individual initiative and intelligence withont the domination of either. We want, more than anything else in Australia, on the economic side of life, a new cra of primary production, a new spirit of conamest, renewed enthusiasm, the creation of more wealth, so that the Commonwealth may carry a larger population, and that there may be national progress based unon better eonditions and a standard of comfort greater than that of anv other country. All this is easy to accomplish, and in no direction can it all be made possible in less time than by the systematic conquest of natural resources-the promotion of rural industries, of which the greatest and most profitable for the nation is that of woolgrowing and meat-raising for home requirements and unrestricted sale oversea. 


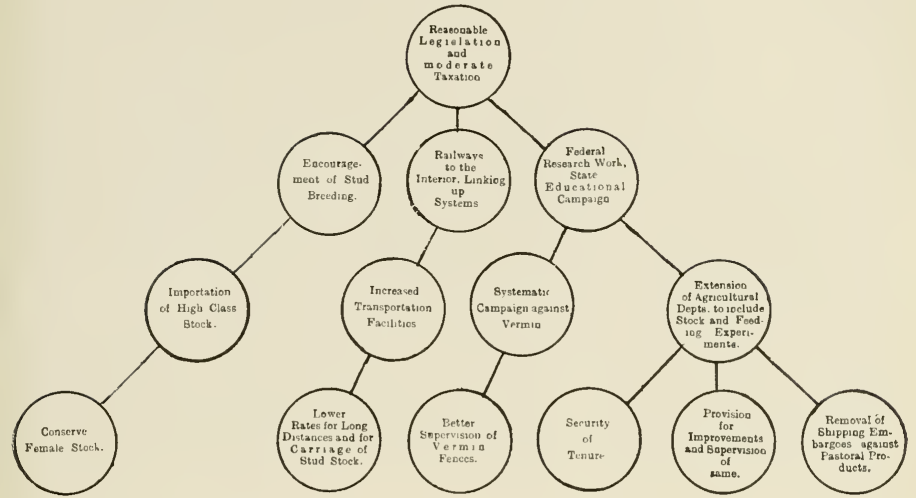

It is by organisation-national and individual-Governmental activity in investigating, experimenting, and educating, so that the citizen shall be well equipped when eoming into daily grips with problems in field and factory and world-wide competitionthat the urgent call for efficiency, economy, and human uplift can find adequate response. Economy in production, saner methods of distribution, and only such legislative eontrol as will give a fair field to the mutual interests of industrially employed capital and labour represent the corner-stone of a true democracy. Before they ean hope to people their vast continent with a virile white race, Australians must understand the fundamental economic factor of national safety and progress, that it is production, and production only, that ereates wealth, pays wages, regulates prices, and fixes the standard of living. The neglect of a country's natural resources is economic waste, and economic waste means public and private loss and eventually national decay.

\section{THE INDIAN ZEBU FOR AUSTRALIA.}

If it is possible to obtain the consent of the Federal Government to their introduction, it is very probable that a large consignment of Zebu bulls will be imported from India into the Northern Territory. 
The breed is tick-resistant, and will practically fatten where our own stock would starve. In parts of the Northern Territory and the north-west, where our cattle suffer large losses from disease and numerous insect pests, these Zebus would thrive and prove a source of profit on thousands of acres of country at present unoceupied. The illustration herewith shows the fine type of cattle that results from the mating of the \%ebu and the shorthorn, and the following extract from a letter from $\mathrm{NI}_{\mathrm{r}}$. William IIcDowall, Christmas Creek, Charters Towers, Queensland, to the Royal Zoological and Acclimatisation Society of Victoria regarding a Zebu bull sent him by the Society, is worth quoting:-

"The white bull I got from you is a very big beast now, and very quiet; his calves are a year bigger than ordinary cattle, eat dry grass in the heat of the day, and get and keep fat where ordinary cattle die; they seem to be immune to all diseases; we never wash or spray them for ticks, and we never even see a fly or insect on the bull himself."

The best of these bulls are largely purchased for America, where they are used with success, for grazing purposes, and Americans would not use them, with the experience they have had, if they did not pay them.

The Zebu-Shorthorn cross is immune to tick fever and tickconveyed diseases, and some interesting information on the subject was recently contributed by Mr. A. Despeissis to the Department of Agriculture in Western Australia. He said:-

"I was collecting information regarding the purchase and shipment to this State of heavy Milking Maltese goats, and whilediscussing the matter of 'Maltese fever,' which these animals are likely to earry, some interesting experiments, consisting of crossing Zebu cattle (Bos indicus), popularly known as 'Brahmans,' with ordinary cattle, was brought to my notice. The object of these experiments was to ascertain whether Zebus themselves or their crosses are immune against 'tick fever,' or 'piroplasmosis,' which is very severe in portions of Algeria.

"The fact which suggested the experiments was that Madagasear, a French colony heavily stocked with humped-back cattle (a strain of Zebu), was free from tick fever, although the tick insects themselves abound there; moreover, in the South African colonies where the humped-back eattle are not bred, European cattle are severely affected by 'red water.' 


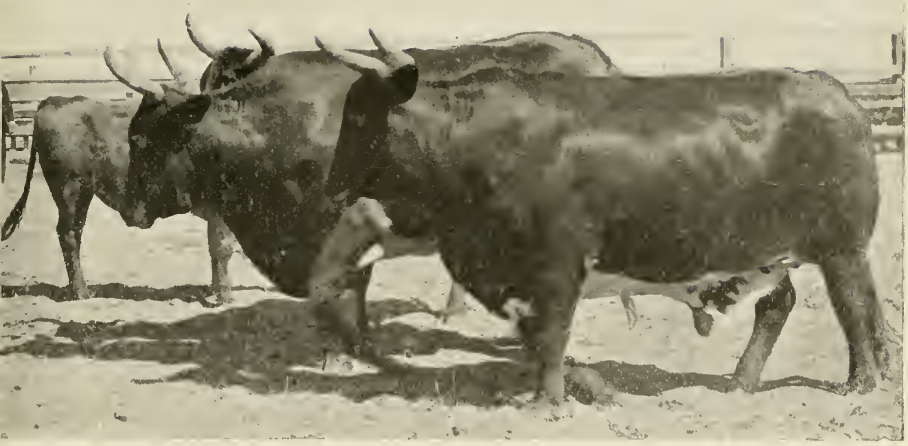

The Zebu-SHorthorN Cross.

"One pelmanent remedy, however, now seems to be suggested as the result of the experiments referred to, i.e., the infusion of Zebu blood into ordinary cattle subject to infection. The attention of a landed proprietor near Bone having some years ago been drawn to the fact that a comple of Zebus he possessed and their crosses were always in good condition, whilst the cattle around suffered greatly or died from the attacks of cattle ticks, led to a careful investigation being made, with the result that it was found that Zebus and their crosses are not so susceptible to the attacks of cattle ticks, and although the micro-parasites of the blood may occasionally be seen on microscopical examination, no ill-effects follow.

"The secretion from the sebaceous glands of their skin has a peculiar odour, which seems repugnant to insect life. 'The hide, though it may be as thin as in European breeds of cattle, appears to be nuch tougher; the hair is quite short, and does not provide favourable shelter for the development of ticks.

" "Young bulls," says Lieut.-Col. Gunn, "sell from 80 to 150 rupees (about $£ 6$ to $£ 12$. Possibly they would cost a little more now). Several fine animals have been exported to South America. During 1906, buyers came from Brazil, and about 200 young cattle were taken awav to that distant country, where the breed has become very popular.' 
"This cross seems to be to the ox what the mule is to the horse; it partakes of the qualities of both parents, but, however, remains fertile. To the ox it owes its streculent flesh and humpless back: to the Zebu the smaller bone and quiek growth, greater activity, hardiness, and resistance to tropical diseases. The Zebu is a tropical ox, and resists there where it has been proved other eattle are carried away by disease. It is not affeeted either by the damp heat or by prolonged drought. which favour such diseases as piroplasmosis, but it eamnot stand too much cold. It will prove a useful animal for our tropies, while in milder elimates it is not required.

"A description of one of the three Zebu-Shorthorn eross raised by Mr. W. McKenzie Grant, near Dongarra, W.A., is interesting. The cattle were sired by a Derrimut Shorthorn bull, the dam being a Brahman cow, a little hump-backed animal weighing $350 \mathrm{lbs}$. or so dressed, and standing eight or nine hands, and which had for many years oceupied an exhibit pen at the Zoological Gardens, South Perth. The respective live weights of the trio were as follows:- 2240 lbs. (six years old), $1840 \mathrm{lbs}$. (five years old), and $1750 \mathrm{lbs}$. (four years old). They were very quict. The dressed weight of the two smallest was 1036 and 1026 lbs. respeetively, that of the heaviest $1270 \mathrm{lbs}$; the hides about $90 \mathrm{lbs}$. green. The beef the butchers pronounced A1; 2 to 3 in. of fat all over the earcase; not very much kidney and caul fat.

"I have purposely dilated on this important discovery, which affects the 600,000 head of eattle we have in the north and northwest, and particularly the half a million head known to be already in the Kimberleys. Indeed, this matter is one which affects the whole of the Anstralian tropies, where the cattle tick decimates the herds.

"If this method of combating the plagne is found suceessful (and it appears to have been in countries such as Brazil and Uruguay), its value to Australia would be enormous."

\section{FIXING PRICES.}

In these days of fixing prices, it is natural that one should turn to history to see if similar experiments have been tried in the past, and how they succeeded. 
In the year 1815, the British Grovermment, with a view to encouraging agriculture, passed a law and fixed the price of wheat at 80 /- a quarter. The law was operative only for a short time, when, in spite of the penalty imposed, wheat was bought and sold at 38/- a quarter, and the statute became a dead letter. A little further back, in the years of the French Revolution, price fixing was the order of the day, and very heavy penalties were imposed on those who failed to bring their produce to market and offer it publicly at the price fixed. The price of wheat was fixed, the price of oats, and the prices of many other things. Instead of having the effect desired, it had the opposite. The low prices fixed caused production to fall off in all directions, and products, especially wheat, became scarcer and scarcer, until bread was almost unprocurable. Every night, long before daylight, crowds gathered at the baker's' shops, and when daylight came fought for the few loaves offering. Children were starving on the highways, and it was a common sight to see women with children in their arms fighting for a crust. The peasants said they would sooner eat their oats themselves than sell them at the price fixed by the Government. The law fixing prices was ealled the law of the maximum. Professor Sybel, in his famous history of the Revolution, says.- "There was great distress all through France owing to the Government putting a fixed price on corn" (wheat). "Owing to the law of the maximum, all goods began to avoid the inarket." "The law of the maximum first frightened the goods from the market and then paralysed production." "The law of the maximum had the effect of impeding trade, and preventing the regular supply of goods to the people." Then the professor goes on to say :- "The case was not so bad in most of the departments with regard to meat, as with bread, because the law of the maximum had forgot to fix a tariff for live eattle, and the peasants had, therefore, slaughtered as few beasts as possible in Robespierre's time, and now brought to market and sold as much meat as was wanted at good prices." "There was plenty of meat obtainable, because the law of the maximum did not apply to cattle." Less than five years of this interference with trade on the part of the Government brought the people to such a state of destitution and misery that at last they awoke to the folly of trying to override natural economic laws; and the National Assembly swept the whole of this legislation from the statute book. Then business began immediately to revive. The celebrated economist, Henry Dunning Macleod, in dealing with this 
question, says:- "Does not everyone know that a high price of corn is the way to attract corn where it is deficient, and a low price the way to repel it from where it is already too abundant?", Then he goes on to say :- "There is a period during which sales are diflicult or impracticable; when the prices are at the maximum the buyer refuses to submit to them: and when they are at a minimum the seller refuses to submit to them." Macleod declares that supply and demand are the cause of value. This, of course, is where there is free competition.

The Federal Government will do well to pause before attempting to fix arbitrary prices for beef and mutton. There are few farmers who do not combine grazing to some extent with agrienlture, and who in bacl seasons for wheat do not rely on their live stock to pull them through. This question deeply affects the two great primary inclustries of the country. The graziers and farmers of Anstralia will have to bear the greater part of taxation resultant from the war. In addition, they have their periodical losses through dronghts, and are having it badly in the Eastern Division at the present time. The higher prices they are getting for their fat stock now will not be all loss to the consumer. The owners of live stock will pay a correspondingly greater amount of taxation, which will relieve other sections of the community to that extent. The fact that fat stock have reached such high prices must, and is, acting as a powerful stimulant to stockowners to make every possible efiort to increase their flocks and lerels. When sheep and cattle were cheaper, stockowners sent large numbers of their female stock to market; not so now. Everyone is hanging on to his female stock with a view to increasing the numbers as fast as possible. This is assuredly one of the canses for the high prices obtaining; but it is only temporary. It is a fixed and immutable economic law that the dearer any product is the greater will be the effort to produce it. For instance, let the price of wheat be $6 /$ - per bushel, and the industry will homnd ahead; hut let the price be : $/$ - per bushel, and the industry will (in the words of Lord Macaulay) droop and wither like a plant in an uneongenial air. The most powerful stimnlant to production is gain.

\section{TRADE AND EMPIRE.}

There has been issued recently by Messrs. W. Weddel and Co. a very valuable "Memorandum on the Imported Meat Tratle (frozen and refrigerated) of the United Kingtom, with Sug- 
gestions for Fostering Production within the Empire." This commmication fixes very pointedly mpon the extent and dangers of foreign penetration. It goes so far as to state that the powerful group of American operators in the British import trade have secured a stronger position, while their British competitors have become relatively less strong, largely owing to the action of the British Govermment. The following have been the main factor's in producing that result, viz. :-

(a) Placing a large proportion of the orders for army requirements in the hands of these American operators;

(b) Commandeering and controlling Australian and New Zealand supplies, which formed the backbone of the British traders' business;

(c) Permitting South American houses, chiefly American, to import considerable quantities of frozen meat for eivil use, while preventing New Zealand and Australian houses from doing the same thing; and

(d) (thereby) destroying the productive and distributing organisations of British firms, while building up those of their American competitors.

In 1913 the world's output of frozen and refrigerated meat was 40 per cent. British and 60 per cent. foreign. In 1916 it was 31 per cent. British and 69 per cent. foreign.

Constructive policy is, of course, necessary for the future, and the memorandum devotes some space to recommendations for avoiding the dangers of foreign penetration in this trade, and making the Empire self-supporting. It asks a question:-"Can Australasia, Canada, and Sonth Africa make up the deficiency from their large but not fully developed stocks?" That is the erucial question. The reply must be: "Not at present, but we believe that in a few years' time, with proper encouragement from the Home and Overseas Governments eoncerned, they could."

As to remedies, we read:- "First of all, it is necessary to interest the Home Govermment sufficiently to elicit from them some definite guarantee against the most favoured treatment, active or passive, being accorded to foreign producers, also a definite declaration in favour of encouraging Empire prodnction.

"Meat required for feeding our troops, both now and in time of peace, shonld be drawn, firstly, from Empire sources so far as these will permit; secondly, from British supplier's of foreigngrown meat; and only lastly from foreign suppliers. Even if relatively full prices were paid for such Empire supplies as 
might be available for this purpose, no commercial treaties would appear to be violated, while the production would be fostered in the Dominions. The remainder of the meat prodnced there would come forward, as hitherto, for sale in the open market on shippers' account.

"If the Government were in this way to guarantee these army orclers at fair prices fixed up year by year for five or seven years (or so long as the grain guarantees continue) fresh supplies of meat to compensate for the prospective Home shortage wonld doubtless be assured by the end of that period.

"The Empire-grown meat taken over by the Government would be limited to the army 's requirements, so that in normal times the total army supply would be produced within the Empire, and the lines laid down for a speedy expansion of these supplies in any sudden emergency.

"The proposal might involve the making of special eontract arrangements between the British Government and the Governments of the overseas Dominions, each colonial Govermment taking steps to distribute its orders amongst the various establishments within its territory, and to regulate and encourage the production of meat suitable for these contracts. The preservation of freedom of action in respect of all meat not included in such army contract would be an essential part of the scheme, if it is to appeal to British independence of character."

Complementary measures include:-

(a) Systematised improvement in the quality of stock in accordance with the needs of the British and other European markets;

(b) Combination between producers and shippers, enabling long contracts to be entered into;

(c) Standardised grading:

(d) Regularity of sailings;

(e) Concentration in selling:

(f) Pooling of shipping, finaneing, and insuring facilities.

The memorandum concludes that the presence of the American Trust in Australia and New Zealand is a source of weakness in any effort to establish the trade on Empire lines by private enterprise.

"The problems raised thereby can only be dealt with hy each overseas State separately, but no satisfactory start can be made in that direction until the principle is definitely adopted by Great Britain, that foreign trading in the food of her people must be eliminated in favour of British trading." 


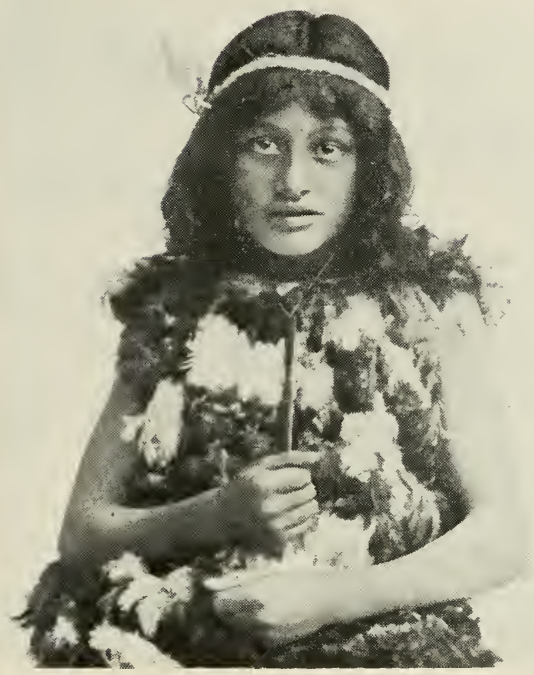

A W.IR WORKER.

The little Maori Princess who shepherds Mr. C. H. Ensor's Corriedale sheep at White Rock, Rangiora, N.Z.

This stockowner's paradise stands alone among all other countries that I am describing as being an ideal stockraising country, with the healthiest of elimates, an absence of serious stock diseases, with the richest of pasture, and the industry of its farmers. New Zealand farmers need never fear that labour troubles are going to block their progress, because they are in the happy position of being able to do all their own work at any pinch which may oecur. Unionists have tried in the past to block the shipment of the farmers' produce, but have been badly beaten every time, until now they reeognise that it is to their interest to work satisfactorily. Another reason why New Zealand is a good and progressive country, is because the bulk of the people own property, mostly of moderate dimensions; therefore, it is hard indeed for socialists or anarehists to get relected to Parliament. 
New Zealand's sheep, at last census, amounted to $26,538,302$, and eattle 2,500,000. Her exports of mutton and lambs in a prewar year amounted to 2,500,000 sheep. 3,500,000 lambs and 55,000 careases of beef, the mutton and lamb shipments alone amounting to $25 \mathrm{per}$ cent. of her flocks.

In the North Island the sheep are almost entirely fattened on grass; but in the south Island, partieularly in Canterbury and Northern Otago, on root crops. The bulk of the beef exports are shipped from the North Island. As will be seen by the list of the meat-works at the end of this volume, New Zealand is well provided with them in every part of the country. Most of these, at the present time, are full of frozen meat of all kinds, and a vast reserve is amaiting Great Britain directly shipping resumes its pristine activities.

It was thought, some years ago, that New Zealand could not much increase its flocks and herds; but serub country, and Native lands in the North Island, still offer great prospeets for stock raising of all kinds, and land which has been ignored in past years, for its poor quality, is now being formd to be good healthy stock country.

A country such as this is only needs men who are not afraid of work, to continue to be regular large supplier of food-stuffs for the Empire. Cattle and sheep are of the highest quality, and every care is taken to ship the meat in the best condition.

\section{NEW ZEALAND FROZEN IIEAT TRADE.}

Mr. A. S. Paterson (N.Z.), writes me "The very interesting eompilation which you published lately in The Pastoral Revieu, is the most complete list of New Zealand freezing honses that has yet appearerl, and is thoroughly up to date."

"I have based upon it another compilation, bringing together. the information it contained, and some other figures bearing on the trade, which, taken together, furnish a somewhat complete statistical view of it from this end, as regards its rolnme and the equipment for earrying it on. The eompilation is appended. The export figures are taken from the valuable half-yearly card issued hy the Shaw, Savill and Albion Company.

"The outstanding features shown are, first, the large numbers of freezing houses scattered over the Dominion, being forty-one in all, when the eight under eonstruction are finished-twentyfive being in the North Island, and sixteen in the South Island. 


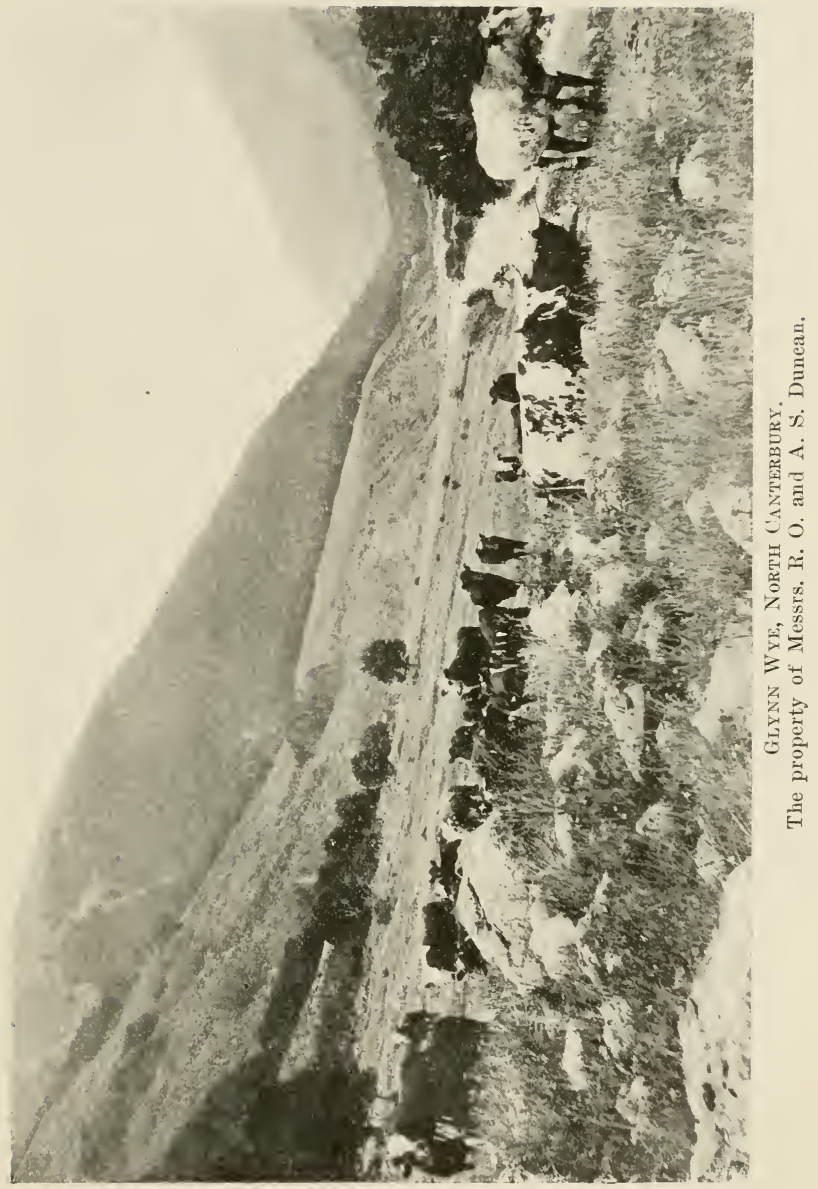


"The number and distribution of these works is such that searcely any farmer in the Dominion can have a fat beast ready any day, or a thousand of them, without a freezing house fairly close by to take them off his hands immediately, and a steamer to carry them to London within a week or two. It comes wonderfully near to that ideal condition for the grazier"not a blade of grass wasted." It is very remarkable that so very far away from the centres of consumption, and for a perishable article, such a favourable position should have been attained by the New Zealand grazier, through means of the refrigerating process. Since the inception of that process, this favourable position has always been present in New Zealand, first latent as it were, and for the last thirty years gradually materialising with the advance of the country and the general progress of the frozen meat trade. It is based primarily upon one thing - the suitability of the country in soil and elimate to grow English pasture grasses.

"The writer was once in the company of several men high up in English public life. The subject of New Zealand came up, and one of them asked abruptly : "What is the chief among the resources of your country? Is it gold or timber, or what?" The writer replied promptly: "It is English grass." The looks that focussed upon him indicated both surprise and doubt of his mental condition. But he had a first-class opportunity to explain the singular adaptability of the eountry to grow these pasture grasses, and produce just the class of meat wanted in England, and the excellent returns which the eultivation of these pastures yielded to the sheep farmer, as well as the leading share they had borne in the advancement of New Zealand.

"Well, these forty-one works have a 'killing eapacity' of 130,300 sheep and 3590 eattle jer day! How full a provision this is for the country's requirements will be understood when it is noted that were the full "killing capacity" put in operation for anything distantly approaching to full time, say, 250 days in the year, it would suffice to put through the killing rooms $32,575,000$ sheep and lambs, and 897,500 eattle, or about nne-third more of the former than there were sheep alive in the Dominion $(24,830,328)$ in 1916 , along with three-fourths of the number of eattle alive at the present time, outside the dairy herds of three-quarters of a million cows. Again, the storage spaee provided at the works is enual to $4.647,000$ sheep of $60 \mathrm{lhs}$. each, or equal to about two-thirds of the rear's export of sheep and 
lambs. These are fanciful ways of putting the matter, no doubt, but they give a striking. idea of the vast equipment that has been provided for carrying on the trade.

"The position, then, is that the country is splendidly equipped with killing and freezing power and with storage capacity. Nothing but a lucrative trade could have prompted all this rapid development. There may indeed be some suggestion on the face of the figures of the equipment being overdone. But it has to be remembered that a freezing house plant must be equal to the maximum daily demand upon it in the best of good seasons, or else it does not adequately serve the requirements of its district or its clientele. But such maximum call upon it only ohtains for a more or less limited season when the grass is at its

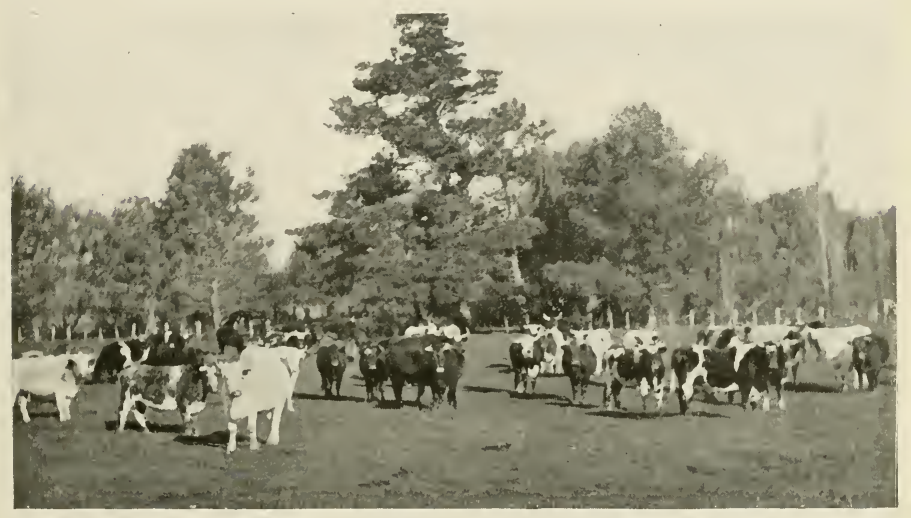

Group of Fat Bullocks, New Zealand.

best, then the supply of stock gradually falls back to a fraction only of what the plant can deal with, but if a given freezing house is not equal to handling the stock naturally falling to it during the heaviest fattening season, the stock will find its way to some competing works. Put it another way, the supply of fat stock must be variable and uncertain, hence this surplus equipment for dealing with a maximum, and not only an average supply. Several times in the history of this business 
it has been doubted if the equipment had not grown too quickly and outstripped the requirements of the trade. But these doubts never lasted long. The wonderful ease with which the apparently surplus plant has quickly been overtaken again and again by the production has been surprising.

"One of the features of the trade almost from its inception has been the co-existence of two classes of freezing works, ri\%, farmer's' works and proprietary works; the latter making a business of buying stock from the farmers, freezing the meat and manipulating the other products for the company's own aceount; while the basis in the former case has been that of freezing for farmer's' account or for account of any buyer from the farmer, and the treating the by-products in a similar way. such companies were projected and owned by farmers and their agents in the first instance. Time has modified their working, and many of these companies now also deal largely in stock for freezing, etc., on their own account. The proprietary companies also ineeze for farmers' account when required, but it is a secondary feature of their business. As near as one can say, seventeen of the forty-one works may be reckoned as proprietary works, leaving twenty-four as farmer's' works. The working of the double system gives most of the farmers the choice of having their stock frozen for shipment on their own account to London, or selling the live stock or the frozen carcases to one of the many buyers for English account. It is a healthy feature that all the ways of doing the business seem profitable. No one ean say that farmer's who have shipped to London on their own account have done better than those who have sold to proprietary works or to local buyers. But the trade goes on healthily and profitably to the satisfaction of all, while both the elasses of eompanies have paid good dividends, and built up the fine plants largely out of profits.

"One can hardly refer to this subject without mentioning the splendid spirit of enterprise shown by the shipping companies engaged in the trade, in keeping up the refrigerated tomnage so well that scarcely ever before the war was a freezing house stopped working because there was not freight to carry the carcases. But since the war broke ont there have been some delays in shipment, arising out of the commandeering of the refrigerated ships by the Imperial authorities for other purposes. The freight dislocation has, however, been less than in many other trades. 


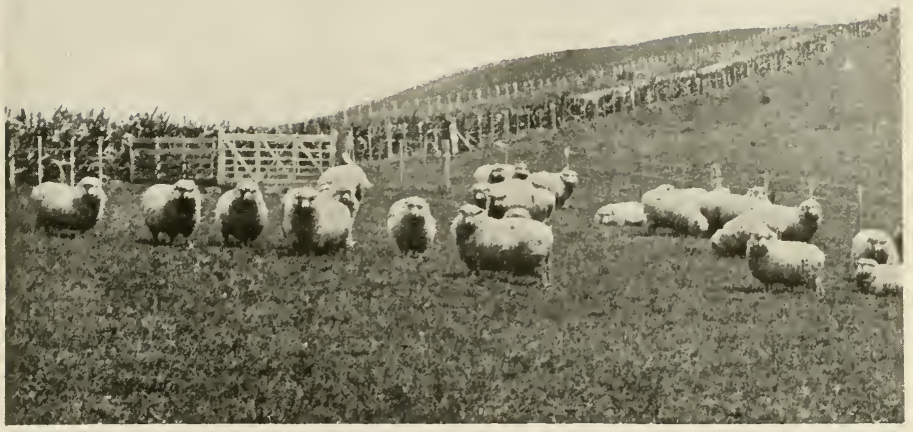

Stud Romneys on Motutara, West Colst, Auckland Province, Norte ISLAND, N.Z.

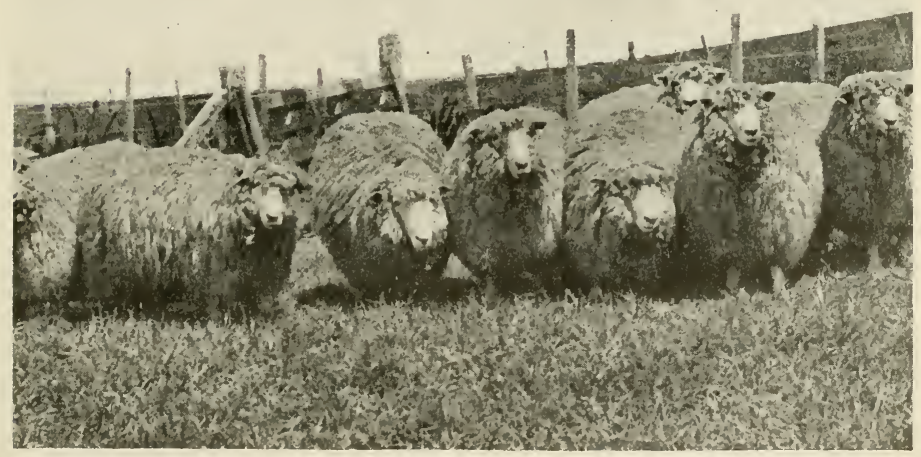

Stud Roaneys on Motutara, West Coast, Auckland Province, North ISILAND, N.Z. 
"The prospects after the war are of the brightest. The good profits reaped by farmers from the war prices may be expected to stimulate settlement and increased cultivation of land. Just what the measure of this may be no one can tell, but no better stimulus to these operations could exist. It is generally recognised that the bringing into eultivation of more land must in the North lsland be very extensive for years to come, and that the South Island is also far from its limit of production in meat. Other markets than London will be competing for our meat. It is believed that America will want the quality of mutton and lamb which we can give them and which they can never get at home. And so the trade which has re-made New Zealand during the last thirty years, may be expected to continue its great contribution to the country's prospects.

"It may be said that New Zealand differs from Australia in not having yet found other markets for meat than the Tnited Kingdom. There were great hopes of a trade with Canada a few years ago, but it only reached a volume equal to 80,000 sheep in its highest year-1913."

Sir Thomas Mackenzie, K.C.M.G., at a recent meeting of the British Cold Storage Association, said:-

"Refrigeraticn was the means of the development of the Overseas Dominions. What were the conditions prevailing before this industry was initiated? Cattle and sheep were almost unsaleable. A leg of mutton could be bought for a shilling. Why, even a sheep was sold in his country (New Zealand) at from $6 \mathrm{~d}$. to $1 /$ - Boiling-down works were established for the mere purpose of extracting fat from the sheep, the rest of the carcase being wasted, and that at a time when meat was so urgently required in the great centres of population in this country. In Australia cattle-splendid bullocks-were sold at $£ 2$ per head. His friend, the late MIr. Christison, who had established the first works at Poole Island, Queensland. had told him that such was the ease in that Colony. In the "History of the Frozen Meat Trade," of which their Secretary (MIr. Raymond) was part author, there was a statement to the effect that eight hundred thousand sheep and seventy-three thousand cattle were boiled down for tallow, producing 110,000 tons, which were sold for $£ 300,000$. That worked out at 2/6 for each sheep, and less than $£ 3$ for each bullock. They could never too greatly honour the enterprising men who began the work in the Overseas, such as Brydone, Roberts, Cooke, Reid, Grigg, 


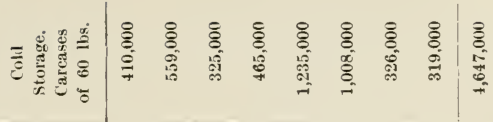

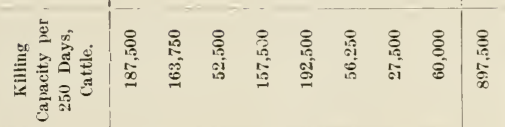

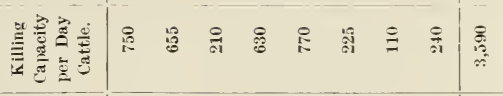

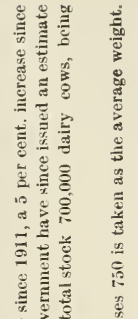

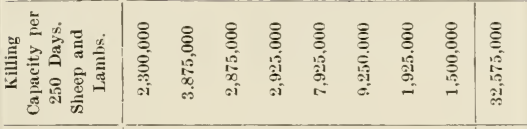

o

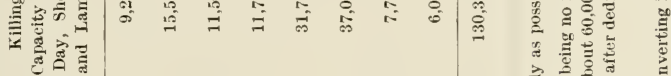

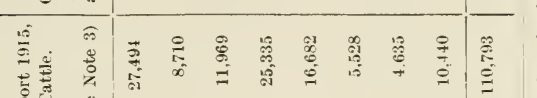

$>\overbrace{}^{2}$

का

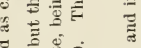

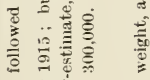

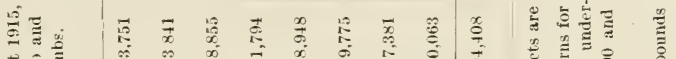
范产产 离

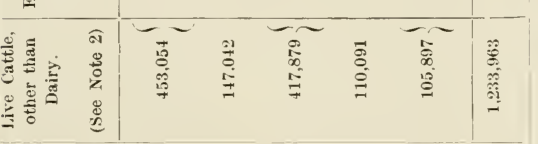

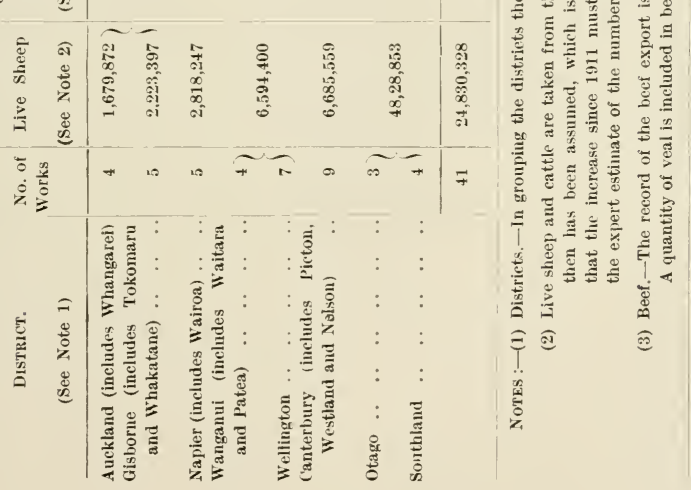


Davidson, and others. The first eargo of frozen meat from New Zealand was sent Home in the ship Duncdin, and the prices realised in Lonclon and Glasgow were $6 \frac{1}{2} \mathrm{~d}$. per $1 \mathrm{~b}$. for mutton and $7 \frac{1}{2} \mathrm{l}$. per lb. for lamb. Only one sheep in the whole cargo was condemned. At that time their flocks were, in round figures, 12,000,000, and it was thonght by those who had studied the question that they could not bear a greater drain for exportation purposes than 300.000 per annum. Later on, $\mathrm{Mr}$. Brydone foretold that it might be possible to export $4,000,000$ eareases. What was the history of the development and its effects on our community?

"New Zealand had exported nearly half the total number of sheep and lambs that had been bronght into the British market since the initiation of refrigeration. The total number of carcases exported to this country was $224,000,000$. New Zealand had sent $107,000,000$ of this number, Australia and the Argentine being responsible for the balance of $117,000,000$. And what of the prosperity that had followed this? In 1880 the population of New Zealand was less than half a million; it was now 1,180,000. In 1880 lands in ocenpation amounted to 24,000 holdings; there were now 80,000 holdings, comprising 42,000,0n0 acres in cultivation, and the capital value of the land was $£ 389,000,000$, as against $£ 100,000,000$ in 1880 .

"It must not be concluded that all this work had been easily done. Its accomplishment required great enterprise, energv, knowledge and eapital. Might he strike a personal note? He was a shareholder in one of the earliest freezing companies, and in later years beeame the Minister of the Department (Agriculture) which had under its charge the supervision of all abattoirs in New Zealand, and the Inspectors who examined every animal before it was exported, seeing to its absolute healthiness, and attaching to every carcase a certificate that it was absolutely free from all disease." 


\section{ARGENTINA.}

Lat. 22 to 56 south; area, 1,139,979 square miles; population, 8,500,000. Bounded by Chile, Bolivia, Paraguay, Brazil, Uruguay and the Atlantic Ocean. This magnificent country is at the present time the main exporter of frozen and ehilled beef in the world and it is not likely, during the next quarter of a century, that any other country will rival it. The most likely one to do it will be Brazil, which will have the advantage of a four days shorter trip to the Home market; but the Brazilians have a very long way to go to eatch up their southern neighbour in the quality of their live stock. The rise of the frozen meat export trade of Argentina reads like a romance, and it is given in detail in that excellent work by the late Mr. J. T. Critchell, and Joseph Raymond, London representatives of The Pastoral Review, "The History of the Frozen Meat Trade." As late as the eighties in the last century, Argentine cattle, of which there were vast herds, were poor and miserable, simply killed for their hides and dried beef. But directly refrigeration was perfected, the wealthy estancieros went to Britain and purchased the very best sires procurable: money was no object, so long as they got the best, and this has gone on ever since. Althongh other comntries get some excellent sires, the very best still go to Argentina, and still they pay the highest prices for what they take a fancy to. Shorthorns, Herefords, Angus, Devons and Lincoln Reds-representatives of all these types still go over, even during these risky times of the submarine warfare. There is still abundant land both for breeding and fattening more cattle. As more land is laid down in Alfalfa, so more eattle can be annually turned off young and of big weights for the freezing works. It is stated by one authority that not one-fifth of Argentina has yet been called into productivity, either for agriculture or cattle raising. Tast areas between Bahia Blanca-the big sea-port south of the river Plate-and the Straits of Magellan, are still available for cattle and sheep, and as their wonderful railway systems spread, these lands become stocked and of more valne to the country. This is where private railways are so much more beneficial to a young country than hiderbound State-owned systems which keep a country comparatively stagnant. Again, there is ample room in the far west, in the northern territories, and even beyond their boundaries on the sub-pasture land of the Paraguayan Chaco, and in the great eattle country of Southern Brazil, to breed far more stock than at present exist. 
Wrest of Bahia Blanca, considerably beyond the termini of the railroads, in the foothills of the Andes, where there is plenty of water and good grazing all the year round-although the winters are quite severe at times-land may be rented from the Government at a very moderate rate incleed.

Cattle ean also be purchased in that territory, in almost any desirable number, at a few pounds per head. It is the eustom there to graze the eattle all the winter, and then in the spring to drive them, by easy stages, to the railroad centres, either east or north, although at times ranchers have taken them across the Andes for marketing at Valparaiso, Chile; but, as a rule, the cattle are pastured on alfalfa lands in the province of Buenos Aires before being marketed.

Althongh, practically speaking, eattle raising ean be earried on in any part of the Argentine Republic, there are regions which, for climatic and topographical reasons, are more specially favourable to the industry than others. Chief amongst such regions is the Pampa district, the climate of which is sufficiently mild to allow of breeding all the year round. Under the denomination of "Pampa" may be included the whole of the province of Buenos Aires, the greater part of those of Cordoba and Santa $\mathrm{Fe}$, and parts of the adjacent provinces and territories, which constitute one immense natural plain, without any greater obstacle to the transit of stock than gradual slopes, small ridges, or, in some districts, woods of greater or lesser extent. The central portion of this region has been known for some years as the alfalfa zone. Alfalfa cultivation, however, has expanded to such an extent on every side of this zone, that to-day the designation records more aceurately the district of its origin than the limits of its actual eultivation. The north of the province of Buenos Aires, owing to its situation on the banks of the Parana and the river Plate, and due to its having been settled longer than any other, is one of the most fertile regions imaginable. After having been for long deroted to sheep raising, it is to-day the principal centre of maize growing. The north-eastern portion of this province consists, generally speaking, of low-lying lands, subject to frequent inundations. The Provineial Government, however, has undertaken drainage works, the completion of which should have beneficial effeet upon the value of these lands. The western district of the province of Bueros Aires, the south of Cordoba, and the province of Santa Fe, the eastern portion of San Luis and the Pampa Central, 


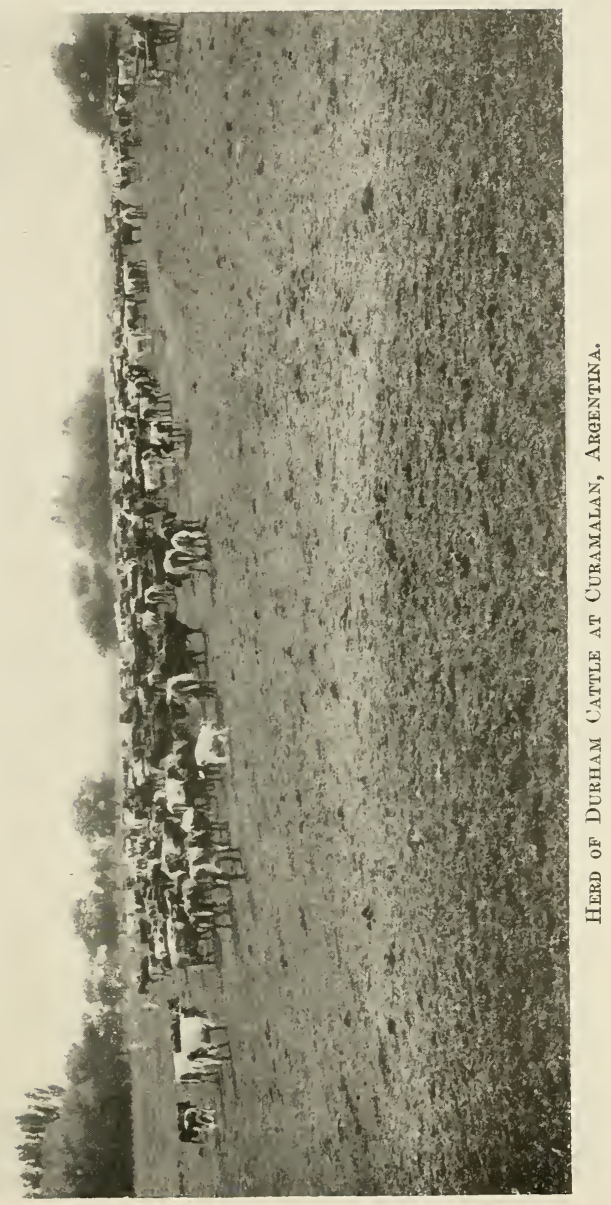


present very slight differences as regards elimate and soil. The Argentine Mesopotamian provinces of Entre Rios and Corrientes, likewise constitute an admirable cattle-raising region, due to favourable climate, abundant pasture, and ample water supply. Lastly, Patagonia, cold and windy, is gradually attaining a position as one of the healthiest sheep-rearing districts of the world.

Argentina is divided into 14 provinees and 10 territories. It is. largely composed of immensely rich plains with great depth of river deposit soil, and is almost bare of trees, except round the numerous estancias, where the owner invariably plants largely. In the Chaco will be found dense forest country. Cattle and sheep are to be found all over the Pampa, from the extreme north to the extreme sonth, where are the territories of Rio. Negra, Chubut and Santa ('ruz. However, the bulk of the good cattle are to be found in the east, or Atlantic, side, and sheep. on the west and south. Patagonia is almost entirely deroted to shecp, nearly all of which are of the various British breeds, or crossbreds.

It is recorded that the first appearance of cattle on the River Plate was early in the sixteenth century, when seven cows and a bull were brought from Brazil, through Paraguay, by two Portuguese, the brothers Cipriano and Vicente Goes; but soon after, large numbers were imported by Juan de Galazary Fspinoza, treasurer to the Govermment. The first sheep were introduced in 1550, and large number's of horses, cattle, and sheep, in a semi wild state, strayed down south to Argentina's rich pastures, from Peru and Brazil.

Roughly, Argentina may be divided into three divisions, and in each separate portion almost all the catile of one class in the Republic are included. The principal herds of Durhams are held within the province of Buenos Aires, the sonthern half of the province of Cordoba, the southern portion of Santa Fe, the sonth-east corner of San Luis, and a small portion of the territory of Pampa Central.

Entre Rios and a part of the south of Torrientes holds the main breeding place for Herefords.

The ontskirts of the country are chiefly devoted to Criolla and grade Criollas, these being eattle bred from the original Spanish importation of hundreds of years back, and afterwards allowed to become wild. Down sonth there are very few cattle, the country being chiefty devoted to sheep. 
The Shorthor'ns are run on the alfalfa and on all the best of the comntry, as owing to their early maturity they give the best results on the high-priced land, and they are very niee eattle indeed. The first impression one reeeives after being struck by the quality of the eattle, is the number run on the area and the quiet nature of the stock.

Pasture.-The indigenons grasses of the Pampa region known as eoarse grass, have gradually been replaeed in a radius of about 150 miles round Bnenos Aires, by the so-ealled soft grass, the seed of which was bronght over by the Spanish invaders amongst

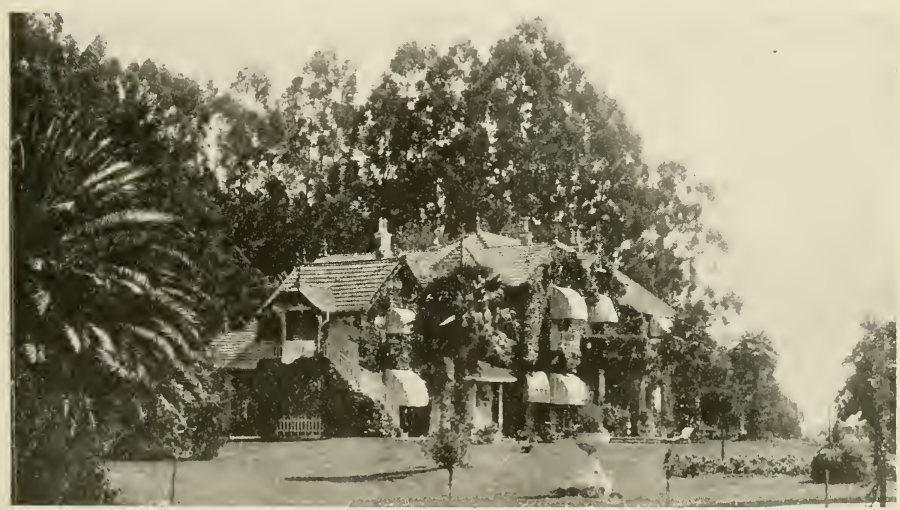

A Wealthy Argentine's Estancil

Mr. Hector Cobo's homestead at "La Armonia," Southern part of Buenos Aires Province.

the forage for their horses. This grass, although actually of little agricultural value, was nevertheless superior to the Pampean grasses. Before the spread of alfalfa the "(queen of the Pampa"), land was elassified as of coarse grass and soft grass.

Estancias.-The year 1878 marked the begiming of a new era of extraordinary development in the Argentine estaneias. In that year, the Indians were finally subdued, and the settlement of an enormous traet of fertile territory beeame possible. High rents and heavy taxation induced many breeders to migrate from 
the inside eamps to the cheaper and less erowded lands thus opened up. In order to defray the eost of the campaign against the Indians, four thousand leagues of land had been sold by the Government, at the price of 400 gold dollars per square league. From 1878 to about 1890 was a period of transition, migration and settlement, no great progress being made in refining stock or in eultivation, or in increased value of land. The increasing areas placed under cultivation in the inside lands compelled all breeders, who did not own their land, to seek new pastures, with the result that from 1890 to the present day an amazing development has taken place. The native type of both sheep and eattle has almost entirely disappeared. The sires imported from Europe have completely transformed the herds and Hocks of a few years ago, so that to-day the average Argentine estancia ean eompare favourably with any other similar establishment in the world. The immense industry opened up with the advent of the freezing companies, and the high standard exacted by the requirements of their European customers, have done much to improve Argentine live-stock. The praiseworthy, and eminently snceessful efforts of the Argentine Rural Society towards raising the standard of Argentine live-stock by means of eattle shows, prizes, publications, and propaganda, entitle them to the grateful recognition of the whole country.

During the past four years, althongh Argentina has increased her beef exports, she has not been ealled upon for her limit either in the export of beef or mutton, and the main stock supply is getting a much required spell. At the conclusion of the war, there should be available a very large supply of a!l kinds of meat products from Argentina.

Recently a friend, who was once a manager of a big Australian station, wrote me from Argentina regarding their methods of working Argentine cattle, and his views were as follows:-

The paddocks are all small, about 1500 acres being a large paddock; usually they eontain between 400 and 500 acres. All classes of stock are kept separate, each age and class rumning in adjacent paddocks; furthermore, all steers are graded, the most advanced being drafted from the others, the one object being to get them fit for market as early as possible. A buyer from a frigorifico would leave in disgust, without offering. if shown bullocks boxed up as is done in Queensland, and was expected to offer for a percentage ont of the herd. The steers being nicely graded, the buyer ean examine each lot, and make his estimate to within a very narrow margin of their killing 
weight. Steers are rarely held until four years old, the majority being disposed of between $2 \frac{1}{2}$ and $3 \frac{1}{2}$ years, and no effort is spared to arrive at early maturity. In many instances, the cows as they calve are drafted from the dry eows to give the calves a better chance, and again the cows with steer calves are drafted from those with heifer ealves, and the former are given the best paddocks to help them along.

The steer calves are dehorned and castrated on most wellmanaged places within the first two months from birth. On some properties they are yarded to do this, but it is mostly done

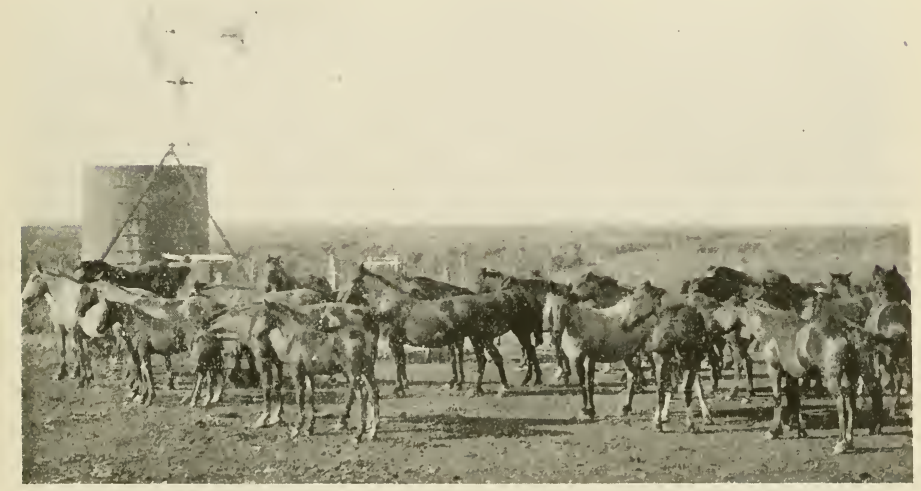

Group of Breeding Mares at “El Sol orro," Province of Buenos Aires,

in the paddocks, the calves being caught with the lasso. Owing to the fact that almost all the properties have no other means of watering but troughs filled from wells, dehorning is of great benefit to the steers, as they do not knock each other about nor take up much space at the trough while watering; furthermore, as almost always stock are trucked when passing from one property to another if any considerable distance apart, or to market, the knocking about in the trucks is minimised. The frigorificos find that there is a very mueh larger percentage of bruised meat from a train-load of horned steers compared with those that have been dehorned. 
Dehorning, though a critel business if left until the eattle have attained a considerable growth of horn, is quite a light operation if done while the calf is young. The most popular method seems to be to eut out the button with a half or threequarter inch gonge and rub on a little stick eaustic. When the beast has a large horn, several varieties of dehorning implements are in vogue, including a saw, all more or less barbarous in use and effect.

The Herefords of Entre Rios are run on poorer quality land, or land which is more suitable for them, owing to their hardy nature and resistance to disease. The paddocks on these properties for the most part are larger than on the better country, otherwise the Herefords are treated much the same as Shorthorns, with the exception that dehorning is not so generally practiset. Entre Rios, as its name implies, has many streams, consecyuently dehorning is not necessary to prevent knoeking about while watering, as on alfalfa camps.

Branding is generally done in the yard in much the same way that it is done in Australia, but rather rougher and much slower.

Cattle drafting in the yard is done through a race, similar to an Australian sheep race on a large scale, the men working the cattle on horseback in the yard, the only footmen being the drafter at the gate and a man or two on the platform outside the race keeping the eattle rumning.

No stock-whips are used with the cattle, but each man has a short-handled riding whip with a lash of raw greenhide about a foot long and $1 \frac{1}{3}$ in. wide, with which he gives the rattle a flip when opportmity occurs. Apart from this, the cattle are handled very noisily and ronghly. The cattle are knocked about a lot by being driven too fast, droving as is known in Australia being imknown in this eountry. One notion that exists is that if cattle are given a gallop occasionally once or twice a week, that is, chased round until they are red-hot, they put on condition more anickly. Nany Englishmen managing there have adopted that notion also. Its effect on a lot of soft steers feeding on green juicy alfalfa ean be imagined, but the eattle do nut suffer from it as much as one would expect, nartly because they are accustomed to being driven very fast, and it does not make them restless. When he has eattle to drive, the average estancia neon, as the stockman is ealled. is in a great hurry apparently, but that is the only time, as he is a leisurely customer as a general rule. 
Inoculating or vaccinating for the numerous diseases gives a considerable amount of work. Vaccination against mancha (black leg) in calves is done almost everywhere at branding time, and there are numerous other diseases to guard against; consequently, the appliances for this class of work are very complete on every up-to-date place, including dips for dipping seabby eattle and from tick-infested districts.

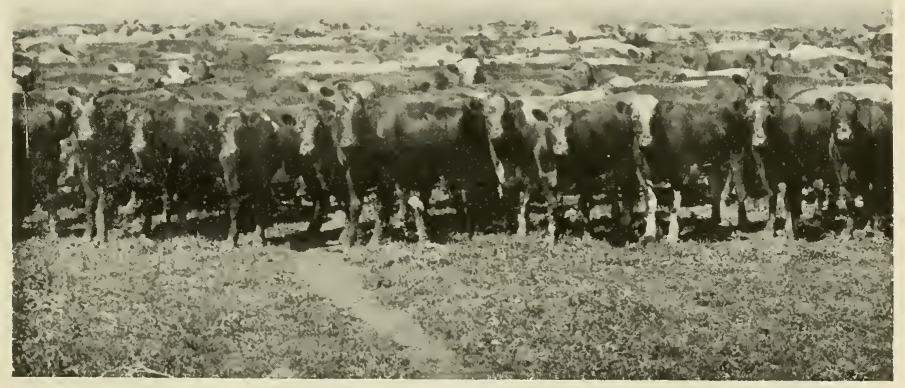

A Point of "Freezer" Stores ready for Transport, Argentina.

The preparation of stock for shows has also attained great perfection. All steers are stall-fed and haltered, and as none of them are more than four years old at the most, they are forced very extensively. The prizes are usually for classes, according to age, from twelve months upwards. In the preparation of the younger stock, calves are forced from two months old, steers of ten and eleven months sometimes getting the milk from three or four cows, in addition to all kinds of artificial foods.

The criollo eattle run on the poor eamps to the west and north. Perhaps they may be said to be hardy, as they can certainly live in lower condition for a long time than any other breed of cattle, but they are very difficult to put condition on, no matter how good the feed, nor do they ever carry a great quantity of flesh, though they are nice meat when fat, not hard and tough 
like the native eattle of South Africa. They are great walkers, and ean walk as fast as an ordinary horse; it is no uncommon feat for a mob of these cattle to be driven 150 miles in three days. As is to be expected, they are ill-shapen animals, and never attain much weight, of all colonrs, and with a great growth of horn. Latterly, they have been in great demand for eanning purposes, as the Hesh has rery little fat. These eattle are chiefly run on unimproved eamps, and are very roughly treated in every way.

Beef-making in Argentina is almost exelusively a grazing business, but it is no longer on the open range basis ! says Mr. ('. F. ('urtis in The Brceders' G'azette, ('hieago). "It is more of a farm pasture business, but the pastures are very large. Few of the cattle seen at the packing plants have ever tasted grain. The greater part of the eattle as they come to market are of uniform quality, showing good breeding. and carrying plenty of flesh for good export beef. They show better breeding than either the farm eattle or the range stock of any other country that is producing beef on a large seale. Most of the eattle from the large estancias are bought direct by the packers or frigorifiens, as they are called. A representative of the packing-house visits the estancias, inspects the saleable stock, and reports to his firm on the number of animals, condition, and feed, and sends an estimate of the average number of pounds of dresser beef per bullock. The eattle are bought on the basis of this estimate. The frigorifico managers deal frankly with the estancia owner, and tel! him just how much beef his eattle macle. The same buyer sticks to the one estancia for a life-time."

\section{SHORTHORNS.}

Shorthorns have been found ideal for most conditions existing in Argentina. The proportion of eattle that have been improved by grading are 75 per cent. Shorthorns, 15 per cent. Herefords, and still fewer Angus. Of registered Shorthorns, between 75,000 and 80,000 pedigrees have been inseribed in their herdbook. Many breeders are not registering their inferior pedigree animals, placing such in their grade herds and using them onlyfor commercial purposes, so that many collections of Shorthorns are to be seen that are pure-bred or showing a predominance of characteristies of the breed where the quality is of high order. The leading live-stock exhibition is held anmully in 
August at Palermo, a beautiful park in Buenos Aires. The stabling is the most elaborate to be seen at any show in the world. The judging is done during two days prior to the inauguration programme. The Shorthorn cattle classes are the prineipal features of the show, and there is no other breed that compares with the Shorthorn in number of entries and the average high quality.

The auction is really the main feature of the Palermo exhibition, as the greater portion of the entries of all breeds of live stock are disposed of at that time. The sales usually consume a fortnight. It is a splendid sight to see classes of Shorthorn bulls, well filled from first to last, and numbering up to 160 in a class. One bull, New Year's Gift, champion at Palemo recently, brought at anction $£ 5.520$, and the result was nicely symbolised in the comments of the Scoteh judge, Mr. Law, who remarked: "A guid bull, but a grand price. I would no mind taking a dozen like him back to Scotland."

\section{Tierra del Fiego ind Solthern Pitugonil.}

\section{(By a ('orrespondent to The Pastoral Review).}

"In comparing the Argentine to other countries, one fact is often overlooked, viz., the number of miles that lie between the 23rd and 55th degrees of latitude, or, in plain words, the extraordinary range of climate, equalled, I believe, by no single country in the world between its northern and southern boundaries. From the mountains of Bolivia to the glaciers of the Beagle Channel, the land falls in a sweep of over 2000 miles with an average width of only 500 miles. Thus, by nature of its formation, the country is insured against a total loss of its products in any one year. It would be more than a coincidence if the sugar and hardwoods of the north, the linseed, wheat, and alfalfa lands that support the immense herds at the centre, the mineral and wine industry of the cordillera, and the pastoral wealth of the south should simultaneously fall on bad times. This explains the conflicting accounts brought back by different settlers, and also in a measure reveals the secret of Argentina's steady advance.

"The Argentine constitution provides for certain provinces, which are distinct from the so-called territories. The former are supposed to be self-governing. They have the full right of internal management and a legislative body of their own. The territories are under the direct control of the central National 
Government, which appoints to them their military Governors and eivil judges. For this additional reason it is difficult to generalise concerning Argentina.

"The first settlers of modern times came to Patagonia from the Falkland Islands. These outlying specks of a former continent luckily for the Republic, form part of the British Empire, else to-day the plains of Patagonia might have remained as in the time of Darwin, peopled but by vast herds of guanaco and the seattered tents of some roving Indians. The islands are preeminently adapted for the breeding of sheep, and it is calculated that at the present time over $2,000,000$ head graze, on the short, wind-swept pastures. Eighteen years ago, the British Government stopped the sale of fiscal lands. This, eombined with the large profits that the well-stocked farms had been yielding, induced certain pioneers to try their luck on the reputed barren mainland of Magellan. The shipment of the first flocks over the 300 odd miles that separate the island from the treacherous coast, was attended with great risk and loss, but the result amply justified the bold venture. In 1882, the lands now occupied by the Patagonian Sheep-farming Company were grazed by only 18,000 sheep. These same lands now support within the boundary-fences close on 300,000 head. This total has been arrived at with no further purchase of stock than those necessary to bring in fresh blood, and in spite of severe winter losses.

"The first stations were planted close to the entrance of the Straits, and land was rapidly taken up along the first and second Narrows. These necks of the sea are but 2 to 4 miles broad, so it is not surprising, after the five years necessary to get the new stations into working order had passed, to find sheep being shipped over to the fertile shores of the "Tierra Del," as it is dubbed with true Anglo-Saxon brevity. The pastures here are superior to those of the Patagonian coast, on account of the unfailing streams of erystal water that traverse the land in every direction. The climate, moreover, presents fewer extremes, and protection is afforded from the bitter south-west winds by the high ranges of mountains at the back of the open ground. It was doubtless the aspect of these same ranges, viewed by the sea captains cruising along their southern shores that pictured Tierra del Fuego as a mass of ice-clad peaks, inhabited only by the bloodthirsty savages that sat perched upon them, anxiously scanning the beach for shipwrecked crews.

"The commercial eapital of all these southern territories is Sandy Point, a town which boasts some 7000 inhabitants, and is 
situated about 50 miles west of the second Narrows. Of Tierra del Fuego Argentina owns but a small area, the ground lying east of a line dropped due south from Cape Virgens to the Beagle Channel. Ushuaia, the Argentine capital here, as well as the town of Gallegos, on the Patagonian sonthern coast, are entirely dependent on Sandy Point for their trade.

"The better camps in Tierra del Fuego will support about 5000 sheep to the square league (9 square miles), and have been sold at public auction as high as $£ 1000$ per league. There are possibly some 1000 miles in the island fit for grazing, of which much is yet fiscal land. This will doubtless be taken up as the country opens ont and a definite settlement is made with regard to the Indian question.

"Half-way up the Patagonian coast is a deep indent bearing the name of the Gulf of San George. The 46th parallel of latitude, piercing its centre, rums across a high barren tableland, to where Lake Buenos Aires, one of the largest of the newly-discovered Andean chain, shows its 70 miles of sparkling blue among the foothills of the Cordillera. This line marks a distinct zone, the land to the south being exposed to colder winds and having a heavier rainfall than that to the north. From Cape Virgens another line, drawn in somewhat irregnlar fashion to where the Pacific has pierced the Andes at Last Hope Inlet (site of the famous Mylodon Cave), gives the Chilian boundary to the south. Between these two boundaries is the territory known as Santa Cruz, the most extensive of all the national territories, as it is also the least settled, with an area of 10,159 square miles and a total population of about 2000 persons.

"Between Rio Gallegos, the first river flowing into the Atlantic north of the Straits, and Sandy Point, lie what are reputed some of the best sheep camps at Patagonia. In a country so little known and of such great extent as that comprised under this title, it is as well to receive such a statement with caution, though it may well be that owing to longer settlement their possibilities have been more thoroughly exploited than those of remoter districts.

"The lands on the coast are generally accounted the most valuable, as the climate is tempered by the sea breeze, while economy in freighting has also to be considered.

"The alluvial soil on the surface reaches a scant 6 in., and overlies a foot of stiff boulder clay. Below this come the 
endless beds of marl, sand, and gravel, which have caused the well-known tablelands to be the subject of so much puzzled controversy in learned circles.

"The first sheep brought to the mainland by the Falklanders were hardy shropshires, with a strong infusion of Merino, a type that was speedily modified, before the settlers stretehed the scemingly limitless plains. The problem given them was to convert their grasses in the shortest possible time into mutton and wool. To this end, larger breeds were introduced, mincipally Linenln and Romney Marsh, and it is from this last-named strain that the majority of Patagonian wools are clipped to-day.

"On these higher pampas of the tablelands the soil is worn perilously thin, small patehes of grass alternating with a surfaee of pure gravel and useless scrub, and Nature's warm provision of wool grew eoarse and luxuriant in the teeth of the blustering winds that swept across them. The newer breeds of sheep imported by the settlers strode joyfully from patch to patch, picking out the softer grasses, and from one long-legged generation to another they waxed fat and kicked.

"The farmer's of Souther'n Patagonia and Tierra del Fuego are mostly hardy Scotch, practical Englishmen, or New Zealanders, as, by the way, are most of their shepherds and hands. The Argentine and Chilian peon has given but poor results in the south, and a traveller may ride from Santa Cruz to Sandy Point and hear no word but English, with, perliaps, a slight smattering of German. As a consegnence, business is conducted on the uncompromising basis of pounds, shillings, and pence, the national paper money being solely a mexlium of exchange. The keynote of life in Argentina's farthest sonth is independence, not to say isolation. It is a rawly new country, even its very formation is geologically unfinished, and it is too big for any man to interfere with his neighbour, to fight him or to help hin. The settler is launched upon the dreary leagues with his flock of sheep. his horse, and his faithful dogs. Whether he be man enough to win out will depend here, more perhaps than in any other civilised land, upon himself alone.

"If the question were suddenly put to them, "What sort of a country is Argentina?' nimety-nine out of a hundred men would reply that it was a level, treeless plain, adding as an afterthonght that it extends half-way up the ridge of the Andes, separating it from ('hili. But in reality four-fifths of the lig Republic is covered by (1) high momitains and their broken foothills; (2) abrupt tablelands; (3) serub and forest. The remaining 20 per cent. is the true pampa. 
"The mistake is, after all, but a natural one, for up to thirty years ago the pampas of the Plate coast comprised all that the settler of that day knew, or cared to know, concerning the country. He had pitched his eamp as near to Buenos Aires as possible, having an eye to cheap freights and a good rainfall, while at the same time he kept in tonch with the political and trading eapital. We must not lose sight of the fact that forty years ago the Indian camps were pitehed within fifty miles of the town. Whilst these gentry were being driven back, the hard grass on his farm gave way to soft meadows, and, as their stecking eapacity increased, so did his yearly balance-sheet show a better return. The land behind him to the west was dry and sandy, and to have refined its coarse grasses by the simple process of grazing wonld have ocenpied many a weary and wasted year. So our pioneer stuck to the eoast, and when they spoke to him of the "outside camps," he shook his head, and said he was all right where he was.

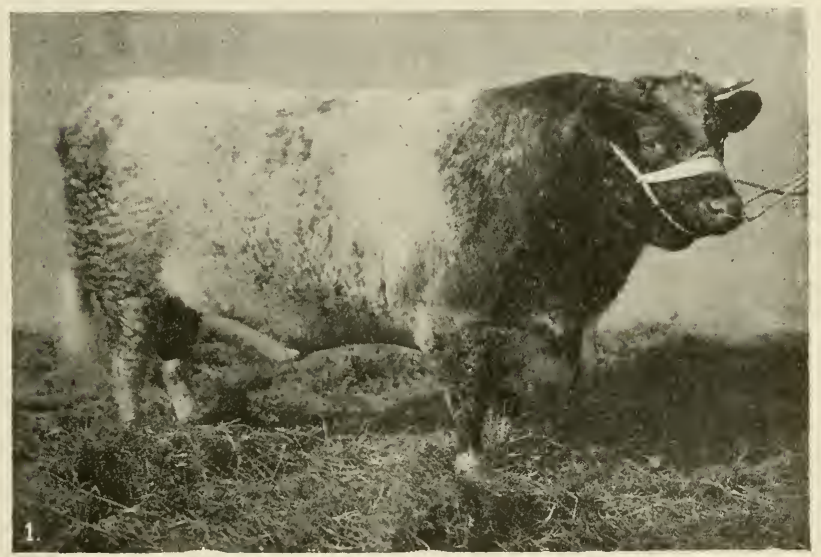

1. Champion Shorthorn Bull, Quilmes Collynie 5 th, 3 years old. Owned by Sr. Leonardo Pereyra, San Juan. Won Shorthorn Society's Cup, MacLennan (up, and Amos Cruickshank Cup (Group of 5). Sold for $£ 2187$. 
"What is the pampa was in former ages covered by a body of water, now commonly known as the Pampean sea. The flood stretehed up to and round the Cordova range standing in the middle of the Republic; in the south it reached to the tablelands of Patagonia; worth to where the slopes of the Cordillera incline to the watershed of the Parana. The formation of the plain marks the different currents that directed the receding waters. We find sand collected by erosion of the mountain chains; vegetable silt carried down by torrential rivers from a tropic interior, mixed with the fossil deposits of a former ocean bed. The general upheaval caused the waters to retire gradually from the neighbourhood of the Andes, the outlet of those subterranean forces which are still continuing their gigantic work, albeit in a more deliberate and less marked degree.

"If we examine the surface of the land, we shall find that, although in certain tracts lying between the Cordova and the Andes the sandy formation resembles that of the central pampas, yet it conceals rounded foothills of barren stone, which make stream and reservoir irrigation the only solution of the water question. Wherever we go north to higher ground we find a forest which, from its stunted outposts on the sandy plains, eloses and thickens to the impenetrable groves of the Argentine Chaco. Again, skirting down the coast from the broad delta to the Parana, we find that the porous sand has been mixed with, and overlaid by, an increasing thickness of alluvial, packed by the rains to a grazing ground of almost unparalleled richness. So, none of these are the lands for which we seek.

"Take now a rough line 200 miles long between the cities of Cordova and Rosario. Drop further a 400-mile perpendicular from Rosario dne sonth towards Bahia Blanca, leaving ontside it all the rounded coastline of the Queen province. Complete the figure by a sonthern boundary that roughly parallels the Rio Colorado, and on the west skirts the detached spurs of the ancient Cordova range. We have now 80,000 square miles, or, loughly, 10,000 square leagues of the true central pampas, the "outside camps" of the coast belt. Our parallelogram is not a very exact one. We must bulge it here, and cut off a corner there; for in Argentina they are not used to be bounded by straight rules, geometrical or otherwise. But if the surface shades from a 6-in. alluvial to a faintly tinged sand: if the subsoil to 100 yards depth is a sandy marl mixed with lumps of freelime that soaks up the uncertain streams venturing from the hills before they ean catch sight of the low-lying coast; if 
the rainfall is between 20 and 25 in.; if as close as $6 \mathrm{ft}$., and not more than $40 \mathrm{ft}$., below the roots of the wiry pampa grass the water comes in strata, brackish, and in some parts undrinkably bitter by reason of the lime-impregnated soil through which it has filtered; if, finally, there is no rock, nor pebble, nor any vestige of the stone age larger than a grain of sand-by all these tokens we may know that we are in the true alfalfa land.

"Twenty-five years ago alfalfa was only grown on the more progressive estancias, and even then in paddocks rarely exceeding 10 to 20 acres. The erop was set aside for imported stock, and for the benefit of such home-grown animals as were deemed good enough to send up to the annual sales at the capital. It was stated that grazing killed out the plant, and, in view of the high cost of establishing it, estancieros wasted year after year in eropping a worn-out and unprofitable pateh. The necessity of finding a drought-resisting forage in the warmer, sandier backblocks, where the summer rainfall was too seanty to keep up tender grasses, induced a more enlightened farmer to give the plant a trial. From the result of that successful experiment we may date the opening up of the central pampas.

"These plains in the natural state will support on their sunburnt tufts of grass a maximum of 500 head of eattle or 2000 sheep per square league (6400 aeres). The same ground laid down in four or five paddocks of alfalfa will maintain all the year round, and turn off in good shape 2000 head of eattle, in addition to 5000 sheep. That is to say, the introduction of this unequalled forage plant has raised the possible production of these pampas from $5,000,000$ eattle, or $20,000,000$ sheep, to $20,000,000$ eattle and $100,000,000$ sheep-an increase of 800 per cent.

"The yield of an acre of alfalfa if eropped may be safely placed at two tons of hay, or 20 tons of ensilage, per annum. The process of making ensilage is as yet very little practised in Argentina in spite of the excellent results it yields. Large fields eut for hay, which might be utilised in this manner, are left to rot owing to an unexpected shower. If the two operations were carried on side by side, it is safe to say that the summer vield of two tons would be angmented by at least five tons ensilage per acre. The total yield for one league (which does not by any means renresent the maximum yield in a good season) then becomes 12,000 tons hay and 30,000 tons ensilage per square league. There is left a sufficiency of short feed to sunport two sheep to the acre during the six remaining winter months. 
"The foregoing figures will give an iclea of the growth of green stuff that a hountiful Nature puts at the disposal of the farmer in this region in an average year. Of the most approvend methods of converting this food supply into mutton, wool, and beef, I have no space to treat. Loeal conditions and a consideration of individual ways and means must always be set before any "counsel of perfection." I only give it here to show what are the eapabilities of the alfalfa region if competition should ever drive the easy-going estanciero of to-day to the more intensive farming practised in less favomed parts of the globe.

"I give a rough summary of the ehief points to be regarded in the establishment of an alfalfa estancia :-

"1. The plant should, if possible, be laid down in a district which will ensure the owner a return on his money while the gromnd is being broken up, i.e., he should not settle too far outside. ()n the camps, whthin a day s carting of a station, his only indispensable outlay will be that of fencing and alfalfa seed, which is at once returned to him in the increased ralue of his property.

"2. If grazed with judgment, the plant will last indefinitely. I have seen paddocks that were over fifty years old. Disking will often renew an apparently worn-out paddock.

"3. As the habit of the plant is to renew its sprouts directly through the crown, it will die out if eontinually grazed dnring its growing season by elose-feeding stock, snch as sheep. In this ease the land will still have been greatly benefited. At a distance of $5 \mathrm{ft}$. below the surface of a five-year-old alfalfa patch there are in the space of one square foot from ten to thirty roots reaching directly to the surface, and averaging one-eighth of an inch in diameter. In addition to this thorough subsoiling, large quantities of ash and free nitrogen, which the plant has the property of storing near the surface, go far to ensure a successful after-crop of cereals. It is probable that in many cases a five or seven years' ley of this kind would be more profitable to the farmer than the policy of nursing his paddocks.

"4. After the land is laid down to alfalfa, the surface strata of water will drop from $4 \mathrm{ft}$. to $10 \mathrm{ft}$. below its original height in the wells, owing to the demands made on it by the penetrating roots. This fact will go far to reclaim low-lying and mosquitoinfested gromuls. The water will tend to improve as more alfalfa is laid down, for the dense growth of the plant ehecks the evaporation of the rainfall. 
“5. The seed should be as clean as possible, and grown in the neighbourhood, in order that it may be well acclimatised. It is more important, and much more economical, to work the gromed thoroughly at the time of sorring the seed than to sow a heavier quantity of seed in badly prepared ground. During its first season the alfalfa should be lightly stocked, and, if possible, mown.

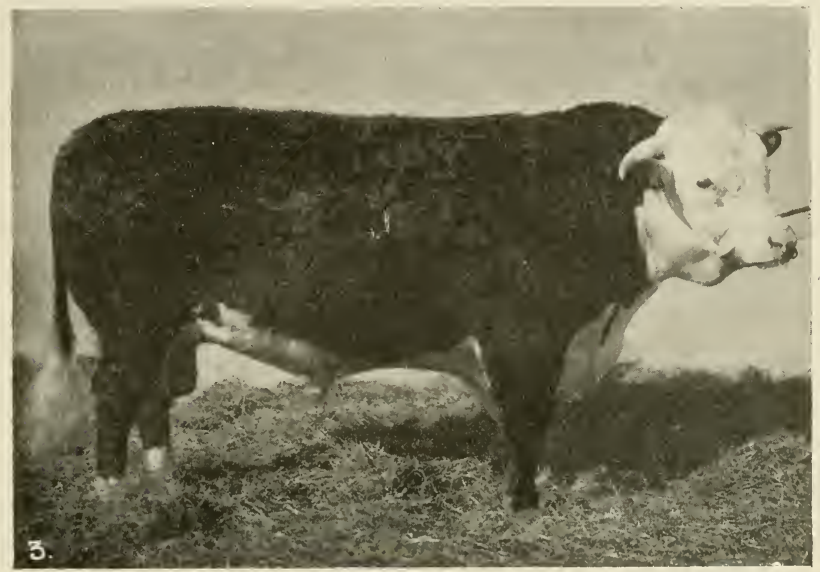

3. C'hampion Hereford Bull, Cameronian 27тh, 3 years old.--Owned by Sr. Celedonio Peredo, Villa Maria. Won the Hereford Breeders' ('ud, Conjunto Prize (with two others), Leonardo Pererra Cup, Cipriano J. Quesada Cup, Hereford Herd Book S'ociety's Cup, and Nicanor Olivera Cup.

"I have met with more prosperity, and found the country opening up faster, in the alfalfa district than in any other throughont Argentina. Yet it must not be supposed that estancia business here is devoid of drawbacks. (Chief of these in many parts, and especially throughout the southern parts of Cordova, is the question of water supply, which, though abundant, is often so undrinkably bitter that it will not. be approached even by the cattle. Where this is the case, it is the custom to make wide, shallow wells, which to some extent eatch the surface drainage. Again, the wind that blows incessantly 
all and every day, save for a short breathing space in early winter, brings with it an invariable accompaniment of dust, flies, and discomfort, which constitutes a very serions factor in home life on a small ranch. The planting of trees and turf will afford a partial relief, but these nuisances will continue, in a more or less degree, as long as the pampa remains pampa.

"Animals are liable to loss from bloat if fed carelessly on the rank growth during springtime, and their meat is pronounced by butehers to be less attractive than that of stock fattened on natural grass pastures. Furthermore, unless money has been freely invested in storing the summer growth, an estanciero may find himself in a very serious quandary at the first touch of winter. Standing feed that would have supported 1000 head of cattle will barely suffice for 200 after a few nights' hard frost. The stoek must be smartly handled during the summer season in order to take advantage of the paddoeks at their point of maximum nutrition, i.e., just before the flowering stage of the plant, and when it is eaten bare the stock should be taken off at once in order to allow the plant to sprout again in the shortest pessible time. A natural eorollary to this rule is that it is impossible to have too many paddocks on an alfalfa farm, and fencing means a heavy outlay on an item which is constantly deterio. rating in value. If the home stock is not sufficient to eat down the summer growth, it should be eut at onee, or fresh stock purchased, for in a fortnight more the standing crop will have lost 40 per eent. of its feeding value, and in another month it will have altogether vanished, leaving no profit, and retarding the growth of its successor. The estanciero must, therefore, reserve at least 30 per cent. of the capital at his disposal for emergeneies, which are eertain to arise at the shortest notice, and whieh will only admit of a ready-money solution. It is this reserve fund which will probably make the difference between handsome profits and none at all.

"Previous remarks will have made it elear that in the region of which we have been treating agriculture is dependent for its ultimate sueeess on the planting and cultivation of alfalfa. Cereal crops, however, form a large proportion of the annual produet and wealth of the district, and their cultivation, given in the order of their importance, is as follows:-

\section{The Argentine Mesopotamia.}

"The watershed of the River Plate basin is eollected from three sources, to wit:- 
"(1) The Cordillera of the Andes, which from latitude 25 deg. in N.W. Argentina rapidly widens to its maximum at the Bolivian "massif" in latitude 15 deg., where it almost tonches; (2) the central highlands of Brazil, dividing the Amazon and the River Plate systems; and, finally, (3) the coast range of Brazil, which starts between the towns of Bahia and Rio de Janeiro, also in the latitude 15 deg., and terminates in the rounded foothills of Uruguay.

"The Brazilian highlands, as they lie sprawling over the centre of the Sonth American map, may be likened to an ill-formed kite. The head, pointing to the Amazon, is fringed by the affluents of that inland sea. The lower sides are stiffened by mountain ranges, that acquire the oceasional dignity of $5000 \mathrm{ft}$. As the tail of the kite, some 600 miles long, passes sonthward through Paraguay, this height drops steadily to $1000 \mathrm{ft}$. At this altitude the range halts finally on the northern boundary of Argentina, overlooking the network of swamps and lazy streams that gives its name to the province of Corrientes.

"In the wide valley between the Andes and the wester"n slopes of this range flows the River Paraguay. Between the east of the same and the hills of the Atlantic coast lies the course of the Parana. Not the plain Parana of the south, but known here in its upper channels as the Paranahyba, or, more generally and simply, the "Alto Parana."

"It would have greatly simplified the geography of all this watershed if the Parana had been able to keep to the eastern side on which it originally started. It would then have entered the Plate estnary by the present bed of the Uruguay, which would in its turn have fignred simply as one of the tributaries entering the great river from the Brazilian coast range. Bnt just north of the spot where their junction would have taken place, a spur of hills juts out, forming a right angle, and almost joining up with the Paragnayan highlands - the tail of the kite. Now, in its hurried upper course, the Parana has earved for itself a deep bed in the soft, red sandstone. But here, in the sonth, its banks have broadened, and it has lost much of its old impetuosity. It cannot, as in the far-off falls of Gnayra, burst its way through the obstacle to pour in a straight flood ever sonthwards. So at the sonth-east corner of Paraguay it is forced to swerve sharply to the west, making a 200-mile boundary for the north of Corrientes. Some 100 miles past the bend the river erosses the last vestige of the hills in a short rapid at Itati (the "many rocks"), which prohibit navigation on the Alto Parana for all vessels drawing more than $3 \frac{1}{2} \mathrm{ft}$. of water. 
"The Paraguay basin has a character entirely distinet from that of its rival. It rums for the greater part in a path reeonquered from the ocean rather than a bed earved out by running stream. At its headyuarter's the lonely lagoon-morass of Xarayes, over 2000 miles from the bustling Argentine eapital, its height is ealenlated at only $700 \mathrm{ft}$. above sea-level. In time of flood both the main stream and its tributaries overflow their low-lying banks to the extent of many hundreds of square miles. Of all these tributaries the greatest now advanees on it. Just above Corrientes the Alto Parana merges in, and swallows up the Paraguay in spite of its reinforeement by the Bermejo, whose month is elearly visible from the town. Then, assuming the right-of-way, it turns onee more to the sonth, and enters the Plate as the Parana proper ("the Mother of the Ocean"). So it has eome about that the Paragmay has lost its pride of plaee as one of the world's greatest waterways, whilst the Iruguay rises into sudden importanee as it takes up the abandoned eastern ronte. When we read that the Plate is formed by the junetion of the Parana and the Urngmay, the statement is true in faet, but not in proportion. The latter river ean boast in all of but a thousand miles of length, whilst the totals of the Paraguay and the Parana together sum over 4000 miles. A better idea would be given if we read: "The River Plate is represented in Sonth Ameriea by Parana and Co."

"It has been neeessary to dwell thus far on the vagaries of the Parana system, inasmueh as they set a straight boundary round the Mesopotamia, elearly defining the lines upon whieh its futmre development must be laid. Its eastem boundary, the River Lruguay, has an average width of one mile. Three hundred miles from its month we find it broken in a series of long, lagoonlike stretehes, whose waters ponr down in alternating rapids, and render serious navigation impraetieable. Briefly, above the town of Concordia, where the first serious barrage oceurs, the Uruguay is a glorified tront stream. On the northern and western limit we overlook the Parana, not, as in its higher reaches, a deep, swift river, but a degenerate Parana-a stream whose width may be three or thirty miles, aeeording to the caprices of its sutden floods, beyond the seope of modern engineering to bridge, and puzzling, with its shallow ehannels ant shifting islands, the most experienced of river pilots. To the south lies the Plate estuary, leading to the oeean. 
"The Mesopotamia, which is bounded by these rivers, is really a peninsula, whose neck in the N.E. corner is the territory of Misiones, the ancient stronghold of the Jesuit power in the Southern Americas. On this side the red sandstone hills fringing on Corrientes have as yet resisted the encroachment of the tropic forest, which commences a few miles further north. Here is the road by which the cattle from the uplands of Brazil find their way to the south-a highway whose importance will be increasingly felt as trade relations between the two countries are drawn eloser.

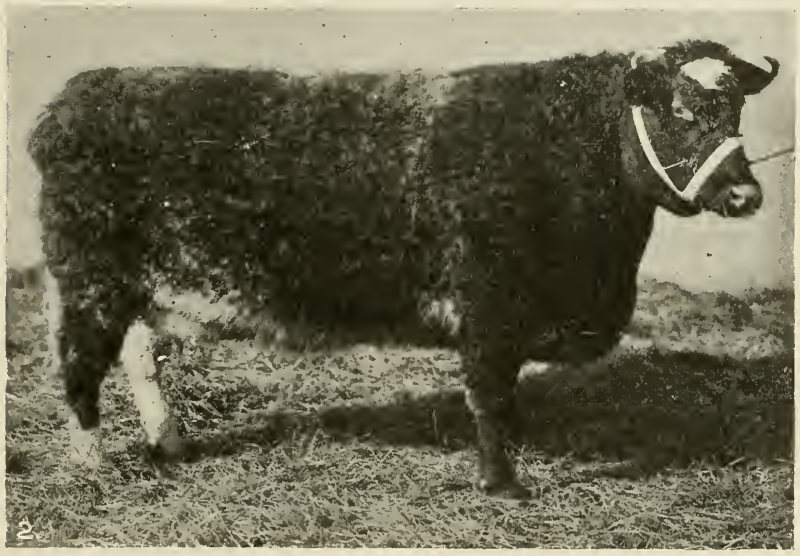

2. Champlox shonthorn C'ow, Ascott Talentine, 4 years old.-Owned by sir. Pedro T. Pages, La Josephina. Won the A. de Bary and Co. Cup, and Family Group Prize (with two calves).

"There is little doubt that at a former period the ocean extended far further into the interior, when the continental waters discharged at what is now the junction of the Alto Parana, the Paraguay, and the Bermejo. From this spot southwards the land rises. Corrientes is gently undulating, and traversed by numerous streams that wander confusedly through marshy bottoms. Entre Rios, set upon the bar of that ancient watershed, rises in riclges of an argillaceous formation, rumning nearly due north and south. Both provinces are covered with a rich 
cap of modern alluvium, save for a strip along the banks of the Uruguay, where the red foothills come down as far as the bar of Concordia, before mentioned.

"Although it is only the north of Corrientes that crosses the line of the tropies, life in this province frankly crosses the semi-tropical stage. This is due to its low general altitude, combined with the near presence of large bodies of fresh water, which convert it during the summer months into a gigantic forcing house. The climate at this season is one of enervating humidity. Maize, sweet potatoes, bananas, and mandioca solve the easy problem of existence for a shiftless lower class. Those who have higher ambitions may undertake the cultivation of a tobaceo patch, selling a poor quality product at equivalent prices. Orange groves are numerous: the difficulty lies in procuring suitable labour to harvest and convey the golden fruit to market. Peanuts will produce abundantly, and the crop is readily bought up by the various oil mills established on the banks of the Parana.

"The real Corrientes industry (the word is somewhat misleading) is stock-raising, and that of a most primitive kind. Sheep are relegated to a second place. The dependence of the estanciero is on his cattle-the red-coloured, long-horned kine, that have become as famous as their brothers of early Texas, and meet with as little favour in the eyes of the city butcher. They have won their place on the principle of the survival of the fittest, for they live and flourish in places where orthodox breeds die of redwater, Texas fever, and similar weaknesses. They may be taken on forced marehes through drought-stricken regions, and their skeletons will still survive. They can wander belly-deep into the great leechy morasses, and browse contentedly on the floating water-grass. Herdsmen freely admit that their bloated appearance after such a diet is not the sign of a firm fatness, but hitherto that has been deemed of but little moment. For at the long last the merit of the Correntino cattle lies in their numbers; they are found on the savannahs of Paraguay, on the uplands of Brazil and Rio Grande. From all points they converge to where, on the lower reaches of the big rivers, the factories (over a dozen in number) lie in wait for them. In Southern Entre Rios, across the river in the "Banda Oriental" - to give to the Republic of Uruguay its old Portuguese title-wherever the earcases are there the saladeros are gathered together. In them the steers are chopped into jerked meat for Brazil and Cuha, discriminated into Paysandu tongues, or boiled 
down to reappear later as Bovril and Liebig's extract on the dining tables of effete Europeans. The export freezing trade of the Plate does not touch this class of stock; it is the roughage of the Republic, and prices rule accordingly. From 10 dollars to 15 dollars gold is the common quotation for fat steers or cows. The number of animals treated by the Entre Rios factories is very large, while the total that vanishes by way of the Mesopotamia every year into the choppers' yards and the melting pots is over half a million.

"From the extreme N.E. corner stretching towards the centre of the Entreriano Peninsula lies one of the unknown and whollyunexplored portions of the Argentine Republic. The great lagoon of "shining waters," the "Ubera," lays under tribute directly or indirectly some 2000 square miles of land. Although the source of the rivers Corrientes and Merinay, its level seldom alters, nor is it sensibly affected by prolonged droughts. Its neighbourhood is heralded by an endless succession of "tacurus" (red ant heaps), which stand from 3 to $6 \mathrm{ft}$. above the ground, or water, as the ease may be. When dry, the whole landscape much resembles a gigantic Chinese graveyard, while the holes under these heaps are the refuge of innumerable snakes. On the edge of the permanent water grows a high, almost impenetrable fringe of rushes. In the inner lake the fecundity of aquatic growth under a tropical sum has led to the formation of islands, that change their shape and station as the capricious winds and floods direct. These floating "terra firma" harbour, amongst other inmates, the gigantic anaconda, a water snake. that attains over $20 \mathrm{ft}$. in length, and in girth the thickness of a man's body. Here it lies, as the natives firmly believe, waiting to devour the hapless gaucho, horse, and all, who shall wander lost in the marshy labyrinths. On these islands, too, superstition places the last refuge of the Jesuit fathers, driven from their pleasant missions to these dark swamps by the greed of the ferocious Mamelukes. Here they still direct their devoted followers of a race fairer and taller than those known to-day, and here at eventide the watcher may hear the faint tolling of the vesper bell, and watch the lanterns move that shed their flickering light over the faithful congregation.

"It is easy from our seat in the railway car (but a few years ago on its first journey through the province) to wave aside such idle tales with the smoke of an after-dinner cigar, but the half-Indian peasant of Corrientes is but a step removed from the serf of the Spanish occupation. Modern sophistry will 
leave him unconvinced until morlern engineering drains the fertile basin, and his superstitions vanish with the miasma of the rush-grown swamps.

"Of the two provinces, that more favoured, both by its own resources and by reason of its unique position on the plate, is undoubtedly Entre Rios. Its rolling lands are compesed of a stitf, black alluvium, overlaying a subsoil well adapted to the planting of trees. There is little trace here of the sand which makes it so easy for the farmer to break up the flat Pampas of Buenos Aires. The limestone deposits near the town of Parana, previous to the discovery of the quarries of Cortova, set up kilns which supplied the whole Republic. Abont one-third of the country is covered with open belts of hardwood, in which the nandubuy predominates.

This tree grows in the likeness of those straight-stalked, bunch-headed parodies that are palmed off on confiding childhood in Noah's arks - a design which Providenee has manifestly created for the purpose of fence-posts. As the land has no companion hills from whieh to tap its water supply, surface springs are rare, but between the rolling downs rum frequent watercourses. Banking these gullies to catch the surface drainage is the eommonest and easiest srstem of providing water to the stock, but it is a broken reed in time of drought, and much of the mortality during recent rears ean be traced to this cause. Well-water may be found at depths varying from 10 to 50 yards, aecording to locality.

"The near outlet of the province to the sea-board, its dower" of fair pastures, and its equable climate, have marked it from the earliest days of Spanish occupation as a desirable possession; yet this very fact has retarded its advance. Happy is the country without a history. Throughout the turbulent growth of the young Republic Entre Rios has been a hot-bed of political unrest-the chosen stumping ground of revolutionists. It was by way of the Mesopotamia that troops were led to fight Brazil in the early twenties, and Paraguay in the seventies of last century; it was across this province that the irrepressible patriots marched who struck for the independence of Uruguay, and it is here that diseontented refugees from that small adjoining State, have ever found sympathy and a safe refuge. Here it was finally that General Urquiza upheld throughont a whole decade the standard of revolt that led to the overthrow of the dictator Rosas, after the latter had ruled the land with blood and iron for over twenty years. And these have been but the main episodes in the drama. 
"In Entre Rios wheat-sowing is not, as in the Pampa region, a mere preliminary to laying down alfalfa. That plant has here a life of three to six years, but it does not attain the phenomenal growth of the west, nor, in the absence of near surface strata of water, is it so capable of withstanding a prolonged drought. Agriculture here stands purely on its own general merils. The lesson to be learned by the colonists is that farming for cereals alone is next-of-kin to pitch-and-toss, and that stock give the most sure and profitable returns when combined with intelligent agriculture. This fact has been sufficiently demonstrated by long years of bitter experience in our own colonies and by the farmers of the United States.

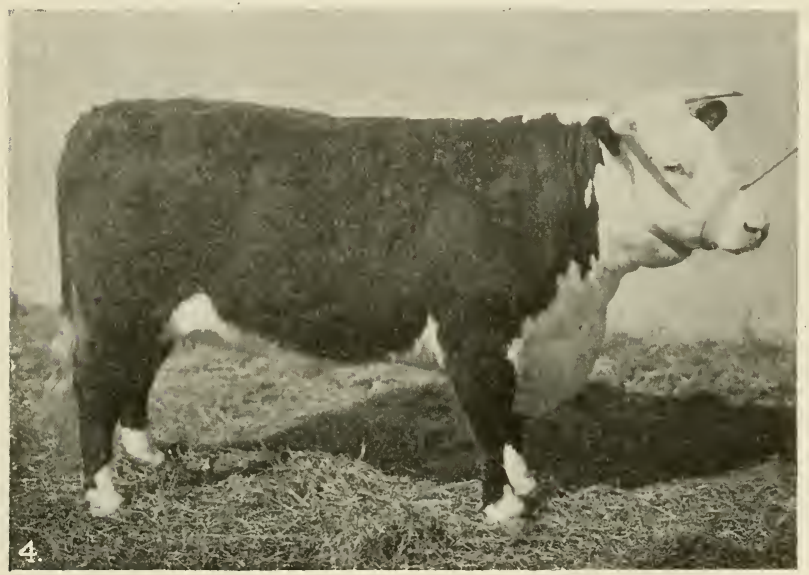

4. Hereford Cow, Plum 25tit, 2 yeais old.-Owned by Messrs. C. E. and B. Duggan, Santa Sabina. Won the P. and G Hughes' Cup.

"The provinee to-day earries 3,000,000 head of cattle, and although most of them, as in Corrientes, are native bred, they contain a growing leaven of finer breeds, notably Shorthorn, which are rapidly improving the mass. The diseases to which these are subject are the same as in the other northern and western provinces, on which $\mathrm{I}$ have already tonched. Carbuncle is less prevalent than in Cordova, and apparently does not get 
such a permanent hold on the ground. On the other hand, Texas fever is even worse than in Santa Fe, on account of the herds of cattle which are constantly marching southwards through the tick-infested marshes of Corrientes. The remedies for the first consist, as elsewhere, in inoculation by Pasteur's lymph; for the second, timely and frequent dippings, to which should be added the burning of all dry, rush-grown bottoms at their periods of maximum infestation by the tick.

"The quality of the native-bred horses of Entre Rios is famous throughout the Plate. In proof thereof, they have furnished in former year's most of the famous 'criollo' polo ponies and to-day give one of the best foundations for crossing with a faster strain.

"Tracts of ground held by the large landowners are being broken up for agriculture in two ways. By the first the colonist works the ground on shares with the owner (who usually has to advance the money for preliminary expenses), leaving the ground when exhansted, and moving on to fresh. This system, with its tendency to high expenditure and slovenly work, has little to recommend it, yet it is largely practised. By the second method the land is thrown open to purchase in instalments covering a period of four or more years, in order that the buyer may, if possible, purchase his ground from the profits made out of it after taking possession. The longer the term granted, the higher the price. It follows that both the owner and the purchaser therefore look with a very lenient eye on the linseed gamble. Yet their ignorance of the best principles of mixed farming ean scarcely be blamed on the hard-working Italians, who form the bulk of the agricultural class. Themselves but a step removed from the working peon, they are naturally disinelined to venture out of a tried, though worn-ont, routine. In no part of Argentina is the want more keenly felt of agricultural stations under systematic Government control.

"It says much for a faith in the future of Entre Rios that the Jewish Colonisation Society have sunk here one-third of the millions of the late Baron IFirsch in colonies on which to establish their countrymen. The character of the Russian or Polish Jew is not often a favourable one on which to build up a thriving pastoral centre, but the colonists are rapidly adapting themselves to their new surroundings. Co-operative dairy-farming has been started with marked suceess. This growing industry has the cordial assistance of the railway local management, which by liberal concessions has made every effort to encomrage these and other settlers in their plucky up-hill fight for prosperity. 
"Let us recapitulate. In the north of Corrientes we find cheap breeding camps, which improve rapidly on being grazed by horned stock, but are unsuitable for sheep. The border-line of the provinces is a halting place, where stock may be interchanged and acclimatised. Finally, on the rich lands near the delta, sheep-breeding, general agriculture, and the fattening of northern eattle may be successfully combined. Here are all the advantages of a near cash market and elieap freights for produce, an ocean port for wool and grain, saladeros for rough stock, and the great freezing factories at hand to absorb unlinited quantities of finer-bred steers and wethers.

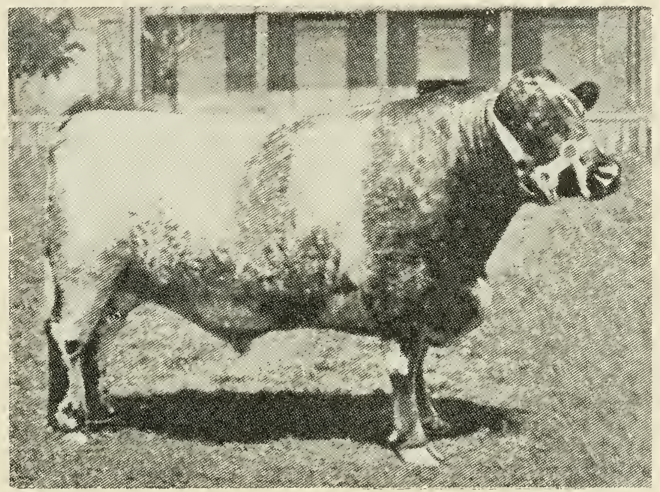

First Prize Fat Shorthorn Bullock, Argentina.

Live Weight, 2112 lbs. Dead Weight, 1919 lbs. Sold for $£ 393$ to Freezing Co.

"There is much hope for the future of Entre Rios and her sister lands. A.rgentine Governor's are generally large landholders, and sometimes practical estancieros as well. In these provinces they are rapidly beginning to understand that their welfare is bound up with a steady development of the eountry's resources rather than in the arena of polities. In the near future, also, the contending railroads must, perforce, cease from troubling, eonsolidating, and extending their systems to that mutual benefit of colonist and shareholder for which they were originally ereated. Then, from the Alto Parana, from the rich 
basin of which Asuncion in Paraguay has long been the centre, most of the rich tropical products and all the quiek traffic will abandon the lazy rivers, with their hazardous bars and twisting chammels, and eome swiftly across the rich peninsula. The long-horned eattle will whirl towards the south on through trueks with inches of extra fat upon their ribs, and the lolling peasant who views the inspiring sight will east away his lomemade eigarette, and get a firm hold on the foreign hoe.

"We are treating of Spanish, and, indeed, to some extent, of Indian-Spanish America; yet the propheey is not far of fulfilment. For the land, which for over a century was a bone of contention between the keen-nosed Spanish and Portugnese explorers, whose fertility received the hall-mark of Jesuit settlement, whieh is hounded by mighty rivers, rich forests, and fertile uplands, and while facing the ocean, holds also the key to the main gateway of the South Ameriean continent, can never fail of a generous share in the tide of mogress, which is steadily carrying forward the best interests of the Argentine Republic.

\section{Tile B.ck CoIntry.}

"It is highly advisable for the intending colonist in Argentina to have a eertain acquaintance with those territories which lie outside of the strictly pastoral zone. They furnish even now a home market for his produce, and as the comntry opens up there can be no doult that certain of these distriets will beeome of mueh greater commercial importance than is at present imagined.

"First in the list we will place the 'Gran ('haeo,' a term whieh meaning literally a thicket, is applied generally to all the tract of forest land south of the Pileomayo River lying between the Andean foothills and the Parana. Its area is close on 9000 square miles (23,000,000 heetares, to he exaet), of which a bare tenth has passed into private hands, and of this, again, but a fractional part exploited. Its formation is distinct from that found in any other forest of tropie South America. A few inches of smrface alluvial overlie a stiff boulder elay, from 10 to $20 \mathrm{ft}$. thick, which in its turn rests upon a substratum of pure sand. All well water must be obtained from this sand, the depth at which it occurs varying in inverse proportion to the distance of the bore from the banks of the great parent river. 
"The timber in the Chaco is not continuous. It oceurs in long, narrow strips, which take a north and south direction, and are interspersed with open ground in the proportion of, perhaps, 40 per cent. forest to 60 per cent. of prairie. These glades are, as a rule, covered with a rough pampa grass, but where the clay lies directly on the surface there is only swamp, worthless eactus, and thomy undergrowth. The whole formation irresistibly suggests a previons inm dation, in which the parts now oceupied by the forest have stood out above the subsiding waters. So strong is the resemblance that the belts of timber are known locally as "isletas," or islands.

"The value of these islands lies in the fact that their woods are composed for the greater part of "quebracho," a red hardwood, which also contains a valuable tanning extract. On this account it resists indefinitely the action of water or dry rot, and is much nsed for fence posts and general construction work. It makes the finest railway sleeper in the world, weighing nearly as much as lignum vitae, with a specifie gravity of 1.27 , compared to 1.33 of the latter. It thus adds greatly to the solidity of a road-bed, especially during the trials of construction.

"A league of good Chaco ground will yield 10,000 tons of quebracho logs. Thus its value depends almost entirely on the cost of timber transport to the nearest station. The limit of profitable cartage does not extent beyond 20 miles from the railway, beyond which the country is practically unknown.

"It will he seen that there is good business in the Chaco, for" the valne of the timber covers both the initial cost of the land and the expense of settling and stocking it with eattle. On the other hand, settlers earn their profits nnder conditions which are the reverse of tempting. The hard, mncompromising nature of the quebracho itself gives the keynote to the whole region. Over more than half the country the Indians, numbered roughly at 20,000 , are still sufficiently hostile to make it necessary for exploiting parties to omit no precautions.

"Nevertheless, the (haco is being steadily invaded. As the hardwoods are ent down the underbrush is fired, and its place is taken by coarse rushes and grass. This in its turn is replaced by softer herbage, which follows on the hoofs of the pioneer eattle herds. Six or eight years suffice to convert dense forest land into moderate nasture. At no verv distant date the Chaco will be shorn of its dreaded forests, and the cattle-raising industry, which is now but a means of feeding the lumber-workers, 
will grow till the district becomes a reserve from which the alfalfa camps of North Santa Fe will draw their supply of horned stock for fatting. The present beginnings of this trade are responsible for the scourge of ticks and tick fever which infests the Santa Fe farms. The Chaco shares with Corrientes the bad eminence of being the natural home of this pest, and neglect of this and similar dangers to the pastoral wealth of the Republic constitute one of the gravest charges against its rulers.

"Let us turn our eyes elsewhere-to the foothills of the Andes that lie west of the pampas of Buenos Aires. The moisturebearing winds, which bring verdure by a thousand rushing streams to the valleys of the Patagonian and pre-Cordillera, are here diverted by the increasing height and solidity of the great divide. North of Lake Nahuel Huapi, the eastern slopes present for over 600 miles a barren and almost rainless tract. It is true that the soil is fertile under irrigation, but the patches which have so far been reclaimed, with the help of the hill-streams, stand out as small oases in a barren wilderness of sand, scrub, and roek.

"This is the wine district of Argentina, and in the year 1900 it produced $125,076,954$ litres. The industry is chiefly centred in the town of Mendoza, lying opposite Valparaiso, in Chili, with the Uspallata pass holding open the gate between them.

"In the broken country that lies direetly north of Mendoza are located the best paying mines as yet discovered in the Republic. Gold is in most cases too thinly scattered in the hard rock to admit of profitable working, but there is plenty of copper, silver, and lead. Mining ventures in Argentina have so far met with poor fortune owing to the difficulties of transport and the situation of the lodes in places where there is neither water nor fuel within reach. Moreover, there is a general impression in Buenos Aires that a league of alfalfa and a herd of good dairy cows is better than any gold mine. They are right. For mining magnates there are few or none; but estancieros prosper in the land, and multiply exceedingly.

"All along where these foothills merge into the great central pampas an increased rainfall permits the growth of coarse grass. Well water here is too far below the surface for even an alfalfa root to reach it, and the scanty herbage only affords grazing for a limited number of poor native stock. Fencing is a heavy item on the seattered barren ranges, nor is there much inducement for the farmer to settle on them, when the fertile lowlands lie so 
close to hand. Goats abound, however, and this region accounts for the majority of the "poor man's cows," of which there are 8,000,000 scattered throughout the length and breadth of Argentina. The rider hurrying through the higher serub of North Cordova is often surprised by a bleat from overhead. A second glance will discover a point of these accommodating animals browsing contentedly amongst the tree-tops, whence they gaze down serenely upon the parched earth.

" On the road beween Mendoza and Valparaiso lies the famous natural 'Bridge of the Inca.' This is the highway of the cattle transport to Chili, which is, however, sensibly diminishing. Owing to the rough shale-strewn roads, which it is impossible to avoid when erossing the pass, all cattle are shod before the ascent begins. This difficult task is earried through with the ease of much practice. The animals are lassoed, and thrown on their broad backs. Their hoofs are secured to four separate stakes, and almost before they are aware of it the novel footgear is firmly fixed for the week's journey. Every peon who works in the cattle trade in this district is a rough farrier, and carries in his roll the tools of the trade.

"When we reach latitnde 26 deg., abreast of the province of Tucuman, the Andean chain grows yet bolder. On the Pacific slope it preserves a fair parallel to the ocean, but it encroaches steadily on the Argentine side, throwing out fresh spurs constantly, till it reaches its maximum in the Bolivian "massif," which rounds off the N.W. boundary of the Republic.

"Earthquakes are felt more on the Chilian than on the Argentine side. The tops of these mountain ranges have from the date of their volcanic birth been abandoned to the merey of fierce air eurrents and torrential rains. Denudation nndes these conditions has gathered at their base, and in the cloven valleys there are pockets of soil of great fertility, covered for the most part with dense forest, and suitable for the growth of sub. tropical and tropical produce. The province of Tneuman called the "Garden of the Republic," is such a pocket, situated at the foot of the Aconquija spur.

"It would be unfair to conclude our review of the Republic withont a glance at Misiones, the smallest of the national territories, which lies huddled between the upper reaches of the Urugnay and Parana, at the point where their waters most nearly approach each other. Comnecting the Mesopotamia with the Brazilian highlands, there is no portion of the Republic which 
has been more written about, and less visited. Three hundred years ago, the Jesuits recognised the value of this unique position at the navigable limit of the two great rivers. In 1732, previons to the clecree that broke their power, the piomeer monks hati brought under their control upwarels of 200,000 Indians; collected in the thirty settlements from which Misiones takes its name to-day. The ridge, which rums through the eentre of the territory to the eoast platean of Brazil is covered with extensive pine forests (Aranearia Brazilensis), and amongst them are seattered elumps of "yerha mate," the miversal brew that takes the place of tea to the working man in the Plate. The lower part of the land, whieh border's the river's, is covered with vahuble hardwoods. But the stoek-growing instinct of the latter-day Argentine colonist is opposed to tropical pioneer. ing, so in spite of the glowing description of seientific enthusiasts: the greater part of Misiones is not only uninhabited, but even unexplored.

"The falls on the Iguazu River, dividing the north of Misiones from Brazil, are of greater height and extent than those of Niagara, though their volume is not so great or so eonstant. The following are the measured dimensions:-Height of Niagara, 150 to $164 \mathrm{ft}$; wilth, $2260 \mathrm{ft}$; height of Iguazu, 200 to $210 \mathrm{ft}$.; width, $9000 \mathrm{ft}$. (nearly).

"The factor whieh must influence the colonist in his choiee of a site more than any other in Argentina is that of transport, and transport here nueans the railroad. The only navigable rivers tap a tropical zone, which is less suited for white colonists than the healthy south. From the Plate to the Straits of Magellan, Bahia Blanca is the only port worthy of the name. On the railroads, therefore, lies the burden of the comntry's business, and their sucessful management is vital to its prosperity.

"Settlers are often tempted by the low priee of rich lands into purchasing farms far beyond the railway zone. This is a good investment for the capitalist, but not for the working farmer. Against the eheapmess of the land must be placed the cost of transport, which remains as a constant charge on the property, while the want of toueh with markets means the loss of many a gond bargain.

"If, however, he has eleeted to try his fortune there, the farmer should rent land rather than buy it, ent his expenses down to the lowest possible limit, and put all his money into his stock. To 
attempt agriculture is unwise, except to supply local needs, it is to give hostages to fortmne, for a sack of wheat cannot walk itself to market, nor can it get out of the way of floods or drought, as the farmers in Chubut and N. Santa Fe know to their eost. For these reasons, eattle are to be preferred when possible to sheep, for while they give less profit, there is also less risk of total loss, and there is no point in Argentina from which their own legs will not carry them unaided to a good market.

"To live, and let live; to know how to combine healthy pleasure and sound business; to eschew polities and law-suits; to deal courteously and justly with all men-these are the lines that have been followed by those of our countrymen who have won for themselves to-day name and fortune in Argentina. There is no real obstacle to deter those who would follow their example. In the bustling marts, or on the wind-swept pampa, in the virgin forest, or beneath the shadow of the great Cordillera, there is room and to spare for all. And nowhere will Englishmen, be he home-bred or colonial, meet with a heartier welcome than from those of his countrymen whose footsteps have pointed a path to the fertile shores of the River Plate.

\section{The Plate Coast Belt.}

"The sheep runs of Patagonia, the alfalfa paddocks of the central Pampas, the rich loams of the Mesopotamia-each zone of Argentina has its advocates. Yet, whatever success may have attended them in their own partienlar distriet, none will deny, when pressed to a statement, that a league of camp near Buenos Aires is worth two anywhere else.

"Apart from its importanee politically, the provinee of Buenos Aires is, without doubt, the richest pastoral district of its extent in the world. The soil eonsists of from 2 to $3 \mathrm{ft}$. of black alluvial top-dressing, rendered friable by an admixture of sand and lime, while below it comes a marl, fairly free from elay, but forming under certain conditions into a hard pan, locally known as "tosca." Rumning through this formation, and separated by these beds of hard pan, are different strata of water, the first of which is found at depths varying from 20 to $70 \mathrm{ft}$., the others following at depths of perhaps only a few yards. As a rule. well-water found near the Plate estuary is of good quality, witness the numerous and flourishing breweries. As we travel west into the Pampas, the influence of its vast volume gradually lessens, till on the plains that stand midway between the Cor- 
dilleras and the coastline the water becomes brackish, and at times undrinkably bitter. This quality is, without doubt, due to the great quantity of free ealcareous matter which the soil, formerly an ocean bed, contains, and throngh which the hill streams percolate on their way to the ocean. The average rainfall of the coast belt is some $35 \mathrm{in}$, and with the usual interlude of a short dry spell in early summer, is throughout the remainder of the year a fairly constant quantity.

"Happy is the country without a history. Happy, we may add, is the farm that has no scenery. The traveller who has no farming interests soon wearies of the monotonous fertility of the panorama that unfolds itself to his gaze from the windows of the excellent trains that serve the rich littoral. He turns with a yawn to the distractions of his magazine, and his verdict, delivered later to inquiring friends, is that Argentina is the flattest country that he has ever seen. It may not be strict grammar-once a country is flat it stays so-but it is strict truth. Sheep at mid-day loom up as big as oxen in the refraction that quivers up from the hot, unvarying surface. Distances are deceiving to newcomers. The fence we start to walk out to appears to be further off than we expected. That dark clump, however, which we take to be the eucalyptus grove shadowing some estancia house is within easy riding distance, for our horizon is limited to a very few miles. As we draw nearer the tree-trunks rise up before us in the very manner of a vessel's masts at sea, and when we finally dismount in their sharle we see on the new horizon around us other clumps, hull down. A colonist could plant his plongh-share in the rich, brown-black earth above Rosario, and, save for an occasional watercourse and the eternal wire fence, draw a level furrow for 700 miles straight south, to where the hills of Curumalan, rising ineonsequently out of the flat prairies, mark the neighbourhood of the port of Bahia Blanca.

"Two hundred miles above Buenos Aires the main current of the Parana has scoured a deep channel at the foot of the tall bluffs that here bound its western bank. This has been a good and sufficient reason for the growth of Rosario, the enmmercial centre of Santa Fe province and second in importance in the Republic.

"Between Buenos Aires and Rosario is found a bed of exceptionally rich alluvial stretching some forty miles inland. This is the pick of the maize country. As the cars whirl along the long 
green rows come down to meet them in seemingly endless parallels, yielding to 80 bushels per acre, even under the rule-ofthumb methods to which the Italian farmer (and they are all Italians here) is wedded.

"A short 30 miles south of Buenos Aires is situated the city of La Plata, a stuceo sepulchre of mis-spent capital, whose sole claim to importance lies in its title to be called the provincial capital. The mania for establishing artificial towns outside a radius of commercial activity furnishes a curious comment on the Argentine character.

"Following the coast for yet another 50 miles, we come to Cape Las Piedras, which marks the entrance of the Plate estuary on the Argentine side, and is also the upper cape of San Borombon Bay. It is an insignificant, poor-spirited bay-a quarter bite from the side of a big apple-but its name has a large significance to the most important sheep-breeding district in the country. The river Salado, rising at a point 200 miles directly inland from Buenos Aires, and resembling a long series of lagoons rather than a river. halts through a series of imperceptible depressions till it reaches the inner lip of San Borombon. Here it meets with a succession of low sand-dunes thrown up along the coast by the action of the tides. After heavy rains, the water is sufficiently served by the narrow outlet of the river, whose bar has, moreover, a constant tendeney to silt up.

"As the coastline falls round into the port of Bahia Blanca, it is roughly paralleled by the seattered outerop of the Ventana hills rumning to meet those of Curumalan, of whose svstem they form a part. The height nowhere exceeds 4000 feet, and on nearing them their rugged outline is found to he fissured by numerous fertile valleys. These collect sufficient moisture to send down half a dozen streams to the coast. the longest of which does not exceed 100 miles, while their volume varies in exact proportion to the local rainfall.

"The progress of the coast belt-as indeed that of the whole Republic-is inseparably bound up with its railway development. The sandy shores do not favour a sheltered anchorage. Between Buenos Aires and Bahia Blanca there is none worthy the name, and Buenos Aires port itself is largely artificial. Within the queen province every ton of freight and every hucket of water must be brought to its destination hv artificial maans. Without railways and wells, the Pampa would he as impossible 
for modern settlers as it was for the Indians who formerly lived on the fringe of the great grass clesert, erossing it only in times of stress, and then in forced marches.

"The first impulse to colonisation was given in the year 1856, when General Mitre-Argentina's grand old man-granted to the Central Railway the most liberal concession ever aceorded in this comntry. It inclucted the free gift of a league of the nation's land on each side of the line along the total length of its construction. The railway, which was the first to connect the towns of Buenos Aires and Rosario, formed a separate department to deal with its real estate, which it sold, and is still selling in small lots and on easy payment terms to boma fide settlers. Thus, the districts through which the line passed were soon colonised. As an unlooked-for consequence, agriculture for over twenty years was practically confined to the north.

"It seems nowadays almost ineredible that landowners should for so long have remained ignorant of the possibilities of the great alfalfa zone in the centre, or that the finest wheat farms in the Republie (those within the radius of Bahia Blanca) should have remained untouched till a few years ago. Perhaps the real reason lay in the absence of any experimental farins. Landowners in the Argentine are a conservative elass, and ineline to a tried and well-worn routine rather than to experiment.

"Intensive farming is practically unknown in the Plate. The reason is that the safest investment for a farmer's spare cash has hitherto been the lands around him, which within twenty years have doubled, trebled, and even quadrupled in value. While fine stock may die and buildings deteriorate, land has none of these drawbacks, and "is bound to go sp." So many new districts have been opened mp, and their purchase and repurchase has absorbed so much of the estanciero's money, that the margin left for improvements has been comparatively small. The land tax, or "contribution directa," favours such speculation. Its percentage on the value of property is comparatively low, and is based on actual rather than potential production.

"Although the province of Buenos Aires now leads in the area laid down to agrienlture as well as in the average rield per acre, there is no doubt that for many years her main interests will still continue to be pastoral. One reason has already been given for this-in the absence of agricultural stations. Another is. that although commereially the importance of a new breed of 
wheat may equal that of blood stock, stock-breeders on the Plate coast enjoy many advantages, or, rather, a combination of advantages, which are denied their competitors elsewhere. Few artificial foods are needed, and these, consisting chiefly of maize and alfalfa, are grown at a minimum cost. The grass which springs up after the introduction of stock to a new pasture is extremely rich, while its growth is practically unchecked thronghout the year. In winter, the degree of cold seldom produces more than a slight hoar frost, but loss is common among thin herds in the driving south-west storms that in early spring sweep unchecked over the Pampas, lasting, sometimes, from three to five days.

"The natural fertility of their pastures has led many, I might truthfully say the majority of farmers, to risk fully stocking their paddocks. This, greatly profitable in a good year, is nevertheless equivalent to overstocking, for a bad season must at times be reckoned for. With no reserves to fall back upon, the result to the farmer is then disastrous."

The freezing companies are helping to improve Argentine live-stock; take shipments of pure-bred pigs, for instance; these are distributed throngh the country to the estancieros and farmers, at cost price, so as to help to improve the present breed of pigs. Export of frozen pork is shortly to be very large from the country. Another way the companies help is in the prices they pay for champion steer's at the fat stock show. This is done to encourage the breeders to go in for high quality. At a recent show, the champion steer fetched $£ 2190$, and three other steers $£ 2270$ each. The Swift Company bought 116 steers for $£ 21,800$, and 333 wethers for $£ 2164$. This company has recently purchased 900,000 square metres of land in Saladillo, province of Buenos Aires, and work on a huge frigorifico is in hand. In fact, new freezing works are being erected in various parts of the country and well up the River Plate. The Government assists companies of all kinds to erect mannfactories, by exemption from all import duties and my making other concessions.

The Sociedad Rural Argentina proposes that a National Congress should be held in which would be represented all the eattle breeders of the whole country. The following points are suggested as being suitable for consideration at such a Congress: Interchange of live-stock with adjoining countries; study regarding the sale of live-stock produce; subsidiary industries; inter- 
national exhibitions; nationalisation of marks and brands; roads, watering stations, and pasturage for the trooping of animals; woolwashing and textile mannfactures; the elefence of the livestock industry; forage, sanitary; exportation of live-stock; freights; the dairy industry ; practical live-stock farming sehools. It is hoped that sueh a congress would be attended by delegations of the National Government and of the mural societies throughout the Repullice. Neighbouring countries would also be asked to be represented, in order to discuss at special sessions of the Congress the four points first mentioned in the above programme.

Summing up the possibilities of this wonderful country of Argentina, they are very large, and Europe ean look to that country for enormous supplies, and probably increased supplies for many years to come. Naturally, as the population increases, more meat will be required locally : but there is ample room in the Republic to increase the live stock at a larger rate than that of the population.

REFriger.tTOR Motor Trecks.

A representative of a large cattle estancia in Argentina recently placed orders in New York for 100 refrigerator motor trueks for use on several estancias. The motors are of high power, with a carrying eapaeity of at least five tons. Each car is equipped with a complete refrigerating plant, so that as the car travels it will keep meats at a low temperature for export shipment. The Argentine eattle-growers plan to kill the eattle on the properties, dress the beef, store it in refrigerator ears in a frozen state, and so send it to the seaports and ship it to North America and Europe. The estancia first referred to, which is to use the refrigerator motor trucks, is 260 miles from a railroad station. Cattle have heretofore been driven afoot from the property to the nearest railroad station or city, and there slaughtered and transformed into export beef. The new plan will eut out the slow movement of eattle on foot, and save much. time and money. It will also open up new meat sourees. 


\section{CATTLE WEIGHTS: LIVE AND DEAD.}

It is always of interest to cattlemen to know how the deadweight of a beast compares with the live-weight; therefore, a few particulars relating to the meat yields of prize animals recently sold at the fat stock show at Buenos Aires will be of interest:-

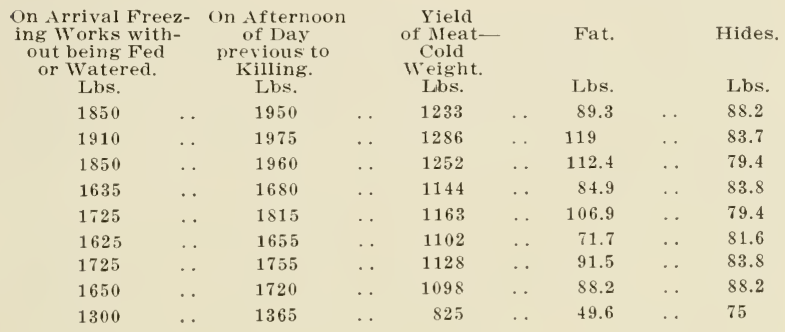




\section{BRAZIL.}

Brazil extends from latitude 9 south to 30 south. It is bounded on the north by British, French and Dutch Guiana, and Venezuela; on the west by Colombia, Ecuador, Peru, Bolivia and Paraguay; on the south by Uruguay and Argentina; and on the east by the Atlantic Ocean. It is a mountainous country, with vast stretches of undulating country with wide valleys containing rich pasture. It covers an area of $3,292,693$ square miles, with a population of over 23 millions.

According to statisties published by the Ministry of Agriculture, there exist $30,000,000$ eattle, $7,000,000$ horses, $3,207,000$ asses and mules, 10,000,000 goats, $7,500,000$ sheep, and nearly $18,500,000$ pigs.

The richest pastoral states are Rio Grande do Sul, Minas Geraes, Sao Paulo, Matto Grosso, Coyas, Piauhy.

The urgent world demand for beef has given the live stock industry of Brazil a tremendous impetus, and the development of live stock raising and the packing house industry will probably make great strides within the next few years.

Until recent years, no serions attempts had been made by raneh-owners to improve their cattle breeds or the general conditions of the grazing lands. Entire lack of transportation facilities and consequent low selling prices gave no stimulus to the industry. The completion of many new lines of railroads, and the recent great increase in the price of live cattle all over the world, have given the greatest impetus to the cattle industry, with the added fact that more attention is being paid to the conditions of production and converting into meat products. Until recently, the losses among cattle anmually were enormous, due to diseases and the lack of proper attention on the ranches. Salt is searce, as the State has no natural deposits, and this aggravates the sitnation in the case of epidemics. Floorls in the low-land section have also bcen an important factor in anmual losses.

With the development of the railroads of the State and the consequent opening of easier foreign markets through Buenos Aires and Monte Video, and national markets through the ports of Rio de Janeiro, Santos, Rio Grande do Sul, Pelotas and Port Alegre, the cattle industry has become more stable and the improvement in the type of cattle has been marked in recent years. 
Several meat companies have erected works, and others are in course of erection. Capitalists from the United States and Great Britain have at last realised what an enormous and handy source of meat supply is available in Brazil, and are now fast developing it.

The export trade has expanded in a remarkable manner, and the country bids fair soon to become one of the most important sources of meat supply. In 1915-the first year of foreign trading - the exports were 8000 tons; in the following year they increased to 33,130 tons ; while last year 66,450 tons of beef were shipped, chiefly to the Continent, for the Italian and French armies. The beef is small and very suitable for those countries.

The Government has offered considerable advantages to breeders of eattle, to encourage the importation of live stock. It intends also to facilitate in every way-both financially and otherwise-the importation of large numbers of first-class cattle; the import of as many as 120,000 bulls is contemplated within the next few years. Already, many head of cattle have been brought down from the United States. Many have been imported from the Argentine, and 60 Zebus were recently imported from India, fetching very high prices. A syndicate is shortly to be formed to import cattle from the United Kingdom, which is to be backed up by the Government. At present, it is only a question of bulls; but it is probable that the idea will also expand to include the importation of cows, sheep and pigs.

The Government is willing to expend also a large sum of money to help the local breeders, and allow free transport by rail. How much more brainy are the politicians in this country to those in Anstralia, where the stock-owner bear's the brunt of all the additional taxation and freight.

Brazil offers a great and remunerative field in the raising of eattle for beef and its many by-products. It has unlimited tracts of land served by railroads, with plenty of rumning water.

It can raise cattle from the valley of the Amazon in the north downward to the most southern State-Rio Grande do Sul-but the centre of this great industry, not only for the fertility of its soil and climate, will always be the State of Sao Panlo, becanse of its geographical conditions and railroad facilities. Most of the beef produced in that progressive part and its neighbouring States will have to be treated and shipped to Santos, the great coffee seaport. Thanks to the activity and vision of the people of Sao Paulo, the export of beef and its by-products is free. 
A great many people in Brazil look upon beef as a product bound to supersede the principal staple-coffee-never realising that this produet is bound to work together with cattle. The fertilisers brought ont by the new industry will be a splendid contribution for the keeping of the coffee trees in better health and for longer years.

At the initiation of the National Agricultural Society (Socieflade Nacionale de Agricultura), the first conference on Brazilian eattle was recently held in Rio de Janeiro. Among the many questions taken up were:-

Probable origin of the different Brazilian breeds, causes of their degeneration, and means of improving them. Mesological influences on the various domestie animals in Brazil. Produetive capacity of Brazilian eattle with reference to all modern industries derived from it. World statistics, producing and consuming countries. Study of the conditions of the consuming world as to quality and quantity. Production and overproduction, supply and demand. Tastes of the consumer, and the causes, whether permanent or temporary. Direct and indirect, Federal, State and municipal assistance in the development of the eattle industry and the improvement of its products.

Thorough and eminently practical courses on all subjects relating to cattle and subordinate industries. Formation of a corps of reterinaries, bacteriological inspectors, and necessary experts, to be attached to all establishments exploiting the numerous secondary industries.

Commercial transactions in eattle and products: large and small companies; co-operation. Necessity to create standards according to the requirements of the consumer. Elements that must be taken into consideration in the location of establishments for the manufacture of and commerce in eattle products: application of natural forces in the operation of plants; shipping ports, docks and railroad stations.

Selection of different systems for the complete utilisation of all by-products. Means of safeguarding the products for consumption: their preservation in the plants, during transportation and at the distributing centres. Preservation of the rarions products by artificial cold. preserving substances, heat, evaporation, ete. Special study of all methods of refrigeration.

Organisation of transportation service with a view to speed, comfort of animals, preservation of products, sanitary require- 
ments, and low freight rates. Direct Government supervision over transportation, from both industrial and sanitary points of view.

Study of all cattle diseases-local and imported-their prevention and cure. How to avoid propagation and to bring about the extinction of animals, parasites, and plants, injurious to cattle. Improvements of pastures, extension of alfalfa cultmre, value of agricultural sub-products as food for cattle.

Also the best methods of raising full-bred saddle, army and truck horses, mules, donkeys, sheep, goats, pigs, and fowls; how to improve the breeds, and a detailed study of all the industries derived from these animals.

Establishment of zootechnic stations and model farms. Practical and eeonomical means of collecting statistics of all the animals of Brazil. Necessity of studying a progressive taxation system to assist the production, consistent with the Government's interests. Legislation. I'niform sanitary inspection of animals in all the States. Prizes to raisers who introdnce new processes to improve breeding.

This shows that the Brazilians are alive to the importance of their pastoral industry.

Brazilian cattle derived from the primitive herds are small, weighing on an average about $400 \mathrm{lbs}$. dressed. IIowever, the importation of sires is rapidly taking place, and the improvement already is most noticeable.

In a paper I read in Chicago before the Congress of Refrigerators in 1913, I forecasted exactly what has happened. In that, I said that Brazil and South Africa would be large suppliers of frozen beef in the near future, and they are both rapidly increasing their herds and their ontput. The following establishments are in full work in Brazil, and more are in conrse of construction :- The ('ompania Britamnica de Carnes, 3000 tons per week: the Frigorifico Armour de Brazil, 1500 cattle, 2000 sheep and 1000 pigs per day ; the Compania Frigorifico e Pastoral de Sao Paulo at Barretos, 300 miles N.W. of Sao Paulo, 350 cattle per day: The Continental Prorluets Company at Ozaseo, 12 miles from Sao Paulo, 800 eattle per day, besides pigs; The Union Cold Storage Company at Mendes, near Rio de Janeiro, with a capacity of 700 cattle per day. The Frigorifico Armour de Brazil is constructing big works at Sao Paulo, and the Compania Swift de Brazil big works at Rio Grande do Sul. 
Transport facilities are being rapidly developed, and new refrigerated steamship services between Brazilian ports and New York have been inaugurated. It is not only in the south, however, that this development in meat shipments is taking place. The Compania Pastoril Agricola-Industrial Piauhyense, with a large capital, has been inaugurated to go into the business of raising and slanghtering cattle and packing meat in the State of Pianhy, in the north; it is in the tropies, but that is no drawback. Most of Australian cattle are also well within the tropical belt. Large areas in the State of Piauhy are excellent eattle country.

Brazilian meat is of excellent quality, a recent shipment of frozen and chilled hinds and quarters registered high-water mark for condition and quality in London. It was nice ripe meat of Hereford strain, small in the bone, with little waste. It made $5 / 6$ for hinds, and $4 / 6$ for fores, only $2 d$. a stone below the best of the chilled meat.

Mr. Duncan Black, a Queenslander who has been residing for several years in South America, recently re-visited Australia, and during his stay here, he favoured me with some first-hand information in regard to primary production in South America. Mr. Black has been closely associated with the cattle trade, and has had unique opportunities for studying its possibilities. With Brazil, he is particularly impressed, as he states that this great territory is on the brink of what must prove to be marvellous development.

The soil and climate of Brazil, according to Mr. Black, are excellent, and the country is permanently watered with rivers and creeks. Water can also be obtained by shallow sinking. Until recently, the cattle industry had not been seriously considered, production having been confined chiefly to coffee and rubber. Now, however, the suitability of Brazil for eattle raising is being recognised, and the country is going ahead by leaps and bounds. The Government is aiding this progressive movement in a most practical manner. A bonus of from $£ 27$ to $£ 34$ is given for every stud cow or bull imported into the country. All implements, fencing material, and other things required by settlers are admitted duty free, and in each of the twenty-one States of Brazil there is a Government stud farm where stud bulls and stallions are kept for the free use of farmers.

Every facility is given to encourage occupation of the land. The freehold title is made as easy as possible to obtain. Anyone wishing to secure land makes application for Crown lands avail- 
able, and the matter is put through with as little delay as possible. Land values range from $1 / 6$ per acre on the high country to $£ 3$ per acre on the deltas of the Alto Paraguay, which is excellent land free of disease.

Mr. Black states that the natural grasses of Brazil are not very good on account of the periodical burning-off they have been subjected to, but it is an easy matter to improve the pasture. The climate and soil, on the whole, are not suitable for alfalfa (lucerne), but a good substitute is found in the native grass jaragua. This grass, apparently, is a great drought resister, and is wonderfully prolific, easily carrying a beast to the acre. To establish this grass, it is only necessary to burn off the rank grass during the rainy season, and then scatter the seed, which is very light and easily obtained. The seed germinates immediately after rain, and the young plants are very fast growing. The first growth of jaragua is left until it seeds, which it does very prolificly. When the seed has been shed, the grass is heavily stocked with eattle, and is well tramped down. The stock are then taken off and the grass is burned off. The young grass comes away again very quickly, and when about 9 inches high, is again stocked heavily, and from then on is never allowed to grow higher than eight or nine inches. After about two years of stocking, this jaragua grass undergoes a change, stooling out instead of growing straight up. It also becomes finer, and can be eut for hay, yielding heavy crops. It is the main stand-by, but another useful grass is angola, a very hardy grass, drought resisting, but not quite so heavy earrying as jaragua. Mr. Black considers that both these grasses would do splendidly in Australia.

The Rio Grande do Sul is the only province of Brazil which has so far gone ahead in the eattle-raising business, chiefly on account of its proximity to Uruguay and Argentina, where good bulls can be obtained at a reasonable price. The rest of Brazil, according to $\mathrm{Mr}$. Black, is on the brink of rapid development. The basis of cattle breeding is the native herds, which are descendants of Spanish cattle run wild. The importations being made are ehiefly Shorthorns, which nick well with the native cattle. Texas fever is the only disease that troubles cattle in Brazil, but it only affects imported cattle, native herds being naturally immune. It is now, however, only a question of the Government arranging to have the imported stock inoculated to remove all risk. 
There are no restrictive eonditions in regard to taking up lanel in Brazil. There are no labour troubles, wages on eattle stations ranging from $\mathrm{f} 3$ to $\mathrm{f}$ ) per month. The native is a good worker, but he has to be taught to handle stock kindly and patiently. Railway construction is proceeding at a great rate, for which purpose English and Freneh capital is pouring into the eountry. ('ommunieation, exeept in a few remote corners, is rery easy, either by river steaners or trains. This was before the war, since when, naturally the influx of capital has stopped from Europe, but a good deal has been going in from the United States.

As an instance of the progress taking place in Brazil, Mr. Black mentioned that the Farmuhar symlieate reently bonght up a very large area of land in different parts of Brazil and Paraguay, which they are proceeding to develop. The syndieate brought a competent staff from Texas to work the properties. They are stocking up as fast as possible, and recently imported 1000 bulls from Texas. Of late years, English people have purehased large properties, and many large landholders in Argentina have sold out and gone to Brazil. The Government gives agriculturists farms ready made.

In conclusion, Mr. Black said:- "After experience in Australia and Argentina, and having been all through Truguay, Bolivia, and Paragnay, I consider there are no better opportunities for brains and eapital than in Brazil.'

\section{BR.lZIL IS A P.ASTOR.IL Country.}

"Of the twenty-one Brazilian States, 'Rio Grande do sul' is by far the most advanced in pastoral matters, chiefly owing to the fact that this state is in elose tonch with Irugnay and the Argentine, with both of which countries she forms the sonthern brazilian limit" (says a special eorrespondent reeently in the I'ustoral Reviru). "Althomgh the class of "attle bred are not to be compared to the stock of the other two comntries mentioned, breeders are now making every effort to improve their herds, and with satisfactory results, as they are now disposing of a good number of stock for freezing purposes. Until recently, all the eattle bred there were slanghtered for the purpose of making "Xarpue" for export to the other states, but with the improvement which has come in the ynality of the bullocks, breeders find that it is more profitable to dispose of their stock to the works buyers, and consenuently are importing good bulls 
in large numbers. Several breeders, thinking that the Zebu would be better than the English breeds, acting on adviee of breeders in the States of Minas and Sao Paulo, where the Zebu has a great reputation, imported them on quite a large scale. No doubt there was a certain amount of reason for importing \%ebus years ago, for the simple reason that they are very hardy, and inmmune against tick fever, which holds sway over all parts of Brazil. The first cross with the native cows gave a rakish, big bullock, and although the meat is very coarse, yet when fat, it made good Xarque, and that was the "end in view."

"The State next in order to Rio Grande is Minas Geraes, which lies north and west of the State of Rio. Ilere we find the Noah's Ark as regards eattle, every breed under the sun being represented, that is if we except the English breeds. Minas is the home of the Zebu, and some very nice specimens are to be seen during one's travels, which is not to be wondered at, considering the money spent.

"Some few year's ago, the Government of this State made a contract with an English firm in Rio to deliver a thousand bulls, meant for distribution amongst the breeders at cost price- $£ 100$ sterling each.

"Of the total, 900 were Zebus imported from lndia, and the balance was made up of Swiss, Dutch, and a few English eattle. It is not an uncommon thing for some Zebu fanatic in Minas to pay as much as $£ 1500$ sterling for a bull he fancies.

"Unlike Rio Grande, which State has excellent native grasses, Minas does not possess native, or, rather, natural camp of any great value. The country has had to be improved in order to carry cattle profitably, and this has been done in a way which one is forced to admire against one's will. Most of the land under Jaragua or Gordura, which are the best grasses, were at one time useless half scrub and half open forest country, and were improved in the following manner: Narrow tracks abont ten feet wide were cleared at different distances, according to the density of the scrub, and the brush piled in rows, which, after having been allowed to become thoronghly dry, were set fire to during a very hot day, generally in the month of November, and when there was a fairly good breeze blowing. Naturally, the dry leaves and grass were completely burnt off, together with the many smaller shrubs, after which the seeds of the grasses mentioned were scattered about, generally by men on horseback, with the result that after the first rain, the grass came away quickly and smothered any new growth of shrubs, the 
ashes left after burning being an excellent grip for the seed, which is very light. November and December being both good rain months, the grass made quick progress, and the land was left unstocked until June of the following year, when the grasses seeded very profusely, and then the land was stocked heavily. After some time, all the seed would be well tramped into the soil, leaving, of comse, quite a lot of decayed regetation, which was burnt off on the first favourable day, after a sliower of rain, and when the old grass was dry. As soon as the fresh spront came away, the land was again stocked, and the grass never allowed to become rank. This may seem to be a very haphazard way of doing things, but as time was no object, and land was cheap, the results were satisfactory. Some beantiful fattening lands may be seen which have been formed in the manner described, and as grazing lands are hard to beat, carrying during the summer months as many as two head of cattle to the acre, and averaging one beast to the acre all the year round. During the winter months, the grass goes off to a certain extent, but makes quick headway with the arrival of spring. These lands are all naturally watered, it being a rare thing to see a well or dam constructed in any part of the country, and being close to the federal capital, have increased in value very quickly. For the newcomer, the prices are a little high; but many opportunities occur when land ean be bought at a reasonable rate.

"Next in importance to Minas, from a pastoral point of view, come the States of Govaz, Matto-Grosso and Parana, and in any one of them the neweomer ean find excellent opportunities for investment.

"Being further inland, land is much cheaper, and looking at matters from a practical point of view, these are the best States to invest in. Large tracts of open rolling downs, well watered by rumning streams, can be purchased at next to nothing; but although the soil is of excellent quality, the grasses are, generally speaking, very poor, owing to the fact that the land has been burned for centuries, and the more tender grasses exterminated. Land can be bought at from $2 /-$ to $5 /-$ per acre, according to the distance from the railways, and, economically worked, ean be improved at about 4/- per acre. As in the State of Minas, burning the grass off when thickly covered, and then sowing the grass seed, has been nntil now the most popular way, but this is not to be recommended. The best way is to run the plough lightly over the land, say to a depth of four inches, 


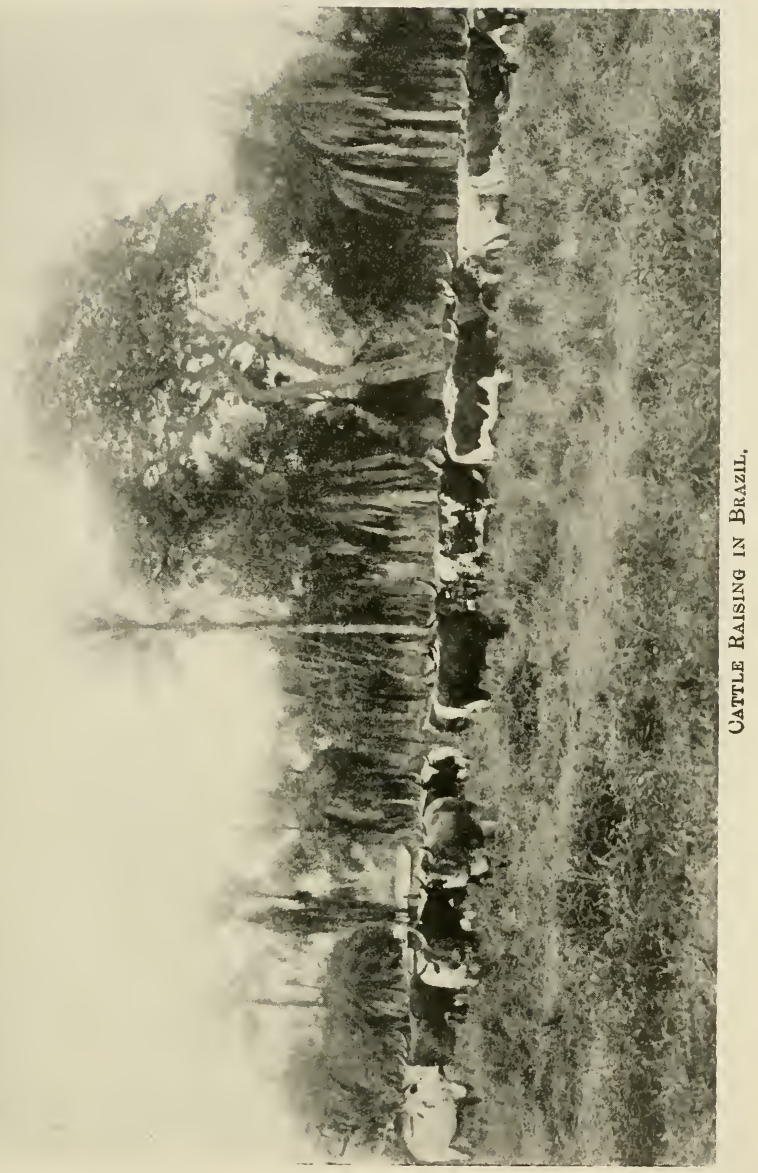


harrow it, and sow immediately, during the months of September, October, November, and Deeember, which are the rainy months, and nature does the rest. The native grasses have very superficial roots, and when turned over by the dise, which is the best for the purpose, become extinct, as after the first shower of rain either Jaragua or Gordura eome away quickly and ehoke ont any few remaining plants. The grass sown in September, that is, provided that the seasons are normal, ean be grazed by 1)ecember, and the stock kept on until April, when it is advisable to retire the stock, allowing the grass to seed, whieh it does about the middle of June. After collecting the seed required for future operations, it is re-stocked heavily, and when well beaten down, if the time is favourable, it may be burnt to clean away and dry rubbish.

"Natto-Grosso and Parana are the two States where the famous Farquhar Syudicate, under the denomination of the Brazil Land, Cattle and Packing Company is working on rather extensive lines. The total extension purchased by this company approximately 6,500,000 acres, the greater part being in MattoGrosso, and includes a lot of excellent natural camp in what is called "Pantanaes," or, in other words, land situated on the banks of the Upper Paraguay river and its afflnences. These lands are subject to floods, but are excellent for cattle raising, the only drawback being that the horses suffer severely at times from "Cadeira," as it is ealled, a disease similar to the horse disease of Sonth Africa. With care, however, the losses are not great, but unless the horses are inspected each morning, and steps taken against the disease spreading, all the horses on the property may be lost, the disease being very contagions.

For the small eapitalist, with, say, from five to ten thonsand pounds to invest, provided that he is a practical man, and not afraid to work, the south of Matto-Grosso is a good place. For those with larger eapital, it is still better, as by importing good bulls in number sufficient to put with all the cows straight away, instead of having to wait, and improve by using half-bred sires, speedy results can be attained, to say nothing of the fact that the larger eapitalist eonld also improve his land much quicker than the man with smaller means. The Government gives free transport for all sires over all their lines, and by subventioned lines of river steamers, and the private companies have followed snit. Seed is earried free, and all agricultural implements at next to nothing; this refers to all lines. 
"With the shortage of cattle in many comntries affected by the war, there is no doubt that Brazil is one of the best countries to invest in, taking into consideration the ruality and price of the land.

An Australian, now resident in Brazil, writes me:- "Brazil, with her vast extent of excellent cattle-raising lands, abundantly watered and easily improved, offers opportunities not to be met with in any other part of the world. No other country is so lavish in Government assistance to pastoralists or farmers; but still progress has been slow in both these pursuits, mainly on account of the lack of initiative of private individuals. The average Brazilian likes polities better than work, so there is plenty of room for the man who wants to work intelligently. To the Australian who has a little capital, I can truthfully state that, comparing the two countries, I prefer Brazil-that is, there is no domineering Government, whose one idea seems to invent new taxes for those who keep the country going, no labour unions whose one idea seems to be the ruining of the honest working men by not allowing them to do enough work to keep them physically fit. I will not elaim that the Brazilian Government is a model one: it makes no pretence to be perfect, but to its eredit may be said that it helps those who are engaged in either of the industries referred to, realising that the future of the country depends on them.

"As to the railway communications, they are much better than in Australia. One can travel comfortably, and at a reasonable rate, anywhere, if the Central Railway-a Government-owned and controlled concern-is dropped out. It is a remarkable thing that Government-controlled railways in any part of the world are usually failures (especially is this so in the Commonwealth of Australia, where you have one of the worst of services, and yet many Australians have asked me if we have decent railways in South America). The "Central" (Government-owned) Railway eosts the country the small trifle of about a million pounds sterling yearly in dead loss, yet lately, an English company offered the bagatelle of $£ 12,000,000$ sterling for the "concern" as it stood. Naturally, the offer was refused, becanse there are a lot of "political friends" to be protected; and so it goes on losing money for the country, instead of being a "paying concern," as it would be were it in the hands of a private company. 
"I do not wish to paint everything the colour of roses as regards Brazil, and I am sure that any Brazilian who may read this report will cordially agree with me as far as railways are concerned.

"If we take any of the other railways of the country into consideration there is no complaint to be made against them, that is, as far as the private companies are concerned. The Paulista, one of the great tracks of the country, may be compared with the best in the world, to say nothing of the Leopoldina, which compares quite favourably with the former. The latter company has done quite a lot for the progress of the country by installing a "model farm," where lads may go for instruction in the art of preparing all kinds of dairy produce, and lately it has started a "travelling agricultural waggon," which travels all over the line owned by the company, showing all kinds of implements, and the expert in charge gives all the information required.

"The former company, the Paulista, have also done pioneer service, insomuch that it is chiefly owing to the efforts of the general inspector, Dr. F. Monlevade, that the export of meat commenced."

There are some splendid flocks of British breeds of sheep owned by a few of the best farmers. In the Rio Grande the Southdown is preferred, and the wool produced is abundant and fine; the Romney Mlarsh is suitable for most parts of Brazil. The plateaux of Parana and Santa Catharina and Rio Grande with an average of $2000 \mathrm{ft}$. elevation are well suited to sheep. Also Central Brazil, 3300 to $4000 \mathrm{ft}$. altitude, with its glorious climate, is specially suited, and in the Rio Grande do Sul there are already over $2,000,000$ sheep.

A London Syndicate, with a eapital of $£ 1,000,000$ for the purpose of stock raising in Brazil south, is in existence.

There are vast expanses of pasturage available for cattle raising. The Brazilian Railway Company have purchased 7,000,000 acres of grazing land, and they say it is just as good as the best North American prairies and there is sufficient supply of native stock to ensure the rapid development of a prosperous industry on a very extensive scale. The Company have already over 150,000 head of eattle, and the number is fast being increased by local purchases, also large numbers of stud cattle are being imported. 
Summing up, Brazil with its $30,000,000$ head of eattle, with the importation of good bulls, American and British brains and push, and with its far seeing politicians, together with its proximity to the big markets of the world, is bound to be within the next ten years a very large supplier of beef, possibly as large as that of its southern neighbour, Argentina. It is a great field for eapital, and one where Labour Inions have not and are not likely to have the opportunity of throttling individual and natural progress.

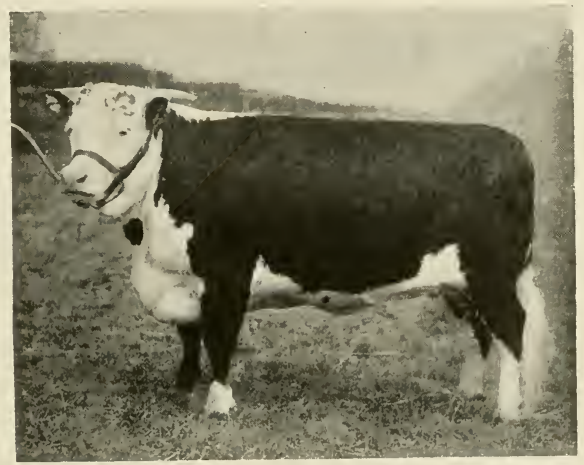

Champion Hereford Heifer, Clive Iris 3rd, English Royal Show. Exhibited By Mr. F. Bibby. 


\section{URUGUAY.}

Latitude from 30 deg. to 40 deg. South

Eruguay is bomeled on the north by Brazil, on the south by Argentina, the west by Paraguay and Argentina, and on the east by the Atlantic Ocean. The area of the comntry is 72,210 square miles, and the population about $1,750,000$. It is the smallest of the South American States. It has a wide almost unbroken sweep of park-like plains with no big monntains. It has a network of rivers, so is splendidly watered; 700 miles of the rivers are navigable. The camp, or grazing comtry, is of a gently rolling nature, and it is difficult to find any large part of it unprovided with a bountiful water supply. The soil is deep and arable, and supplies good pasture for the herds of eattle and sheep grazing on it. The climate is mild, with no extremes of heat or cold, ant the live stock industry is the chief source of the country's commerce, $37,500,000$ acres of the total area of the Republie being given over to pasturage.

For a long time the preparation of jerked beef (tasajo) was a leading intustry in Lruguay, and during one year over 700,000 cattle were slanghtered for this product alone, making over 113.000.000 pounds of meat, with a value of about $£ 1,300,000$.

The number of eattle are about $8,000,000$ and sheep abont 24,000,000. My last visit to Truguay, in 1913, showed me that very great improvement has taken place in reeent rears in the flocks and herds throngh the introduction of stud cattle and sheep from Great Britain. Merino sheep predominate, and the wool industry is a large one. Refrigeration has stepped in, and the exports of meat are jumping ahead. As most of the cattle are beef eattle, there is no reason, excent shortage of freezing works, why the export of beef should not amount to $1,500,000$ quarters per anmm even at the present time.

There is another process by which cattle meat is utilised. Few people are aware that much of the beef extract on the markets comes from the special establishments in I'rugnay erected for that purpose. The word Liebig is now actually strnonymous with beef extract; and the eompany 's factory is at Fray Bentos, on the Cruguay River, about 100 miles above Buenos Aires, but where there is a depth of water sufficient to allow the entrance of ressels of a draft of $20 \mathrm{ft}$. Fray Bentos has been called the greatest kitchen in the world, and on some days 2:500 head of cattle are slaughtered and treated. 
There is room for greater development, because, with all that has been aceomplished, the limit of economic productivity is a long way from being reached. With the steatily inereasing demand for meat and meat products in all the consuming markets of the world, with the well-known adaptability of the people of Uruguay for agrieultural and pastoral life, with the encouraging tendeney to aid immigration to the country, and the facility with which new settlers are absorbed into the population, Uruguay takes a favoured place among the eattle countries of America.

An Uruguayan law of 8th January, 1916, extends for five years the period during which building material and machinery for the construction of meat-packing establishments are to be admitted free of duty into Uruguay. The exemption from duty by such articles was previously authorised for a period of five years by a law of 13th July, 1911.

The first freezing plant in Uruguay was the Frigorifico Uruguaya, established at Montevideo. It has a present daily eapacity of 1200 steers and 4000 sheep. In 1911 Swift bought three jerked beef plants located near Montevideo, and commenced the erection of a freezing plant with a capital of $4,000,000$ pesos. The company soon became a leading factor in the Uruguayan eattle market, and has a present eapacity of 2000 steers and 3000 sheep per day. A Morris plant, known as the Frigorifico Artigas, las a eapacity of from 1000 to 2000 steers, 2000 sheep and 500 hogs per day. 


\section{PARAGUAY.}

The Republic of Paraguay is situated in the centre of the South American continent, between latitude 17.15 deg. and 27.31 deg. S., and longitude 54.5 deg. E. and 62.30 deg. W. The country has no seaboard, being bounded on the north by Bolivia and Brazil, east by Brazil, south and west by the Argentine. Paraguay proper, the area of which is estimated at 65,000 square miles, lies between the rivers Paraguay and Alto Parana, and is bounded on the north by the Brazilian provinee of Matto Grosso. To the west, between the rivers Paragnay and Pilcomayo, lies the little known region of the Chaco, the area of which is estimated at 107,000 square miles, or about that of Italy. All Paraguay belongs to the formation of the low-lying region which is comprised between the Brazilian coast range on the east and the Andes on the west, and through which the two great waterways, the Paragnay and the Alto Parana, flow towards the south and pass into the vast estuary of the River Plate. Paraguay proper consists for the most part of a level or gently undulating plain, from which in some places low hills rise abruptly. These hills nowhere reach a height of more than $2000 \mathrm{ft}$. above sea-level, while the average height of the plain is about $550 \mathrm{ft}$. The level country consists of grass land alternating with woods and forests, the latter oceupying the greater area, while the higher ground almost everywhere is clothed with dense forests. It is well watered by the numerous tributaries of the great rivers, while a large part of the level ground on the west side of the Cordilleras is swampy and liable to inundation. The Chaeo differs from Paraguay proper in that it consists exclusively of level, searcely undulating ground unbroken by hills of any kind. The greater portion of the territory, which seems formerly to have formed the bed of an inland sea, may be regarded as the delta of the River Pilcomayo. At the last census, 1915, there were 5,250,000 eattle and 600,000 sheep in the country.

The livestock industry in Paraguay is one of the most prosperous, and one of the most productive. There is a sure market in the country or in the Argentine. The demand is always greater than the supply and to-day more than ever. The eommercial world has discovered in Paraguay an appreciable reserve in livestock, and the demand will eontinue to inerease.

Paragnay lands have always been noted for their healthy condition, and Paraguay stock for their prolificness. Animals are born and develop with very little personal attention. The 
abundance of pastures, water, and the scarcely sensible climatic changes offer exceptional conditions suitable for livestock production. If the almost wonderful resources of vegetable food be added to the natural conditions of the country the results would be doubled. The inter-breeding during centuries among the native animals, and the negligence in preserving the camps, abandoned for centuries, have produced in the Paraguayan livestock a considerable depreciation in quality.

Good management will correct these defects. The crossing of the native with pure breeds should be the first improvement to be undertaken. The cattle rancher's object should be the improvement of the breed; that is what is really needed. The system employed until lately by ranch owners has been to hold large tracts of land, unattended, with a heavy number of animals, without occupying themselves with breeding good animals; this system must he abolished. What ean be done will be seen by the excellent lessons given by the neighbouring Republics who have obtained the renewal of the greater part of their stock, with enormous benefits to the industry.

Meat is naturally very cheap, perhaps cheaper than in any other country in the world, since a bullock $3 \frac{1}{2}$ to 4 years old is worth only 15 dollars to 20 dollars gold. The hide, tallow and grease being worth alone one-half that amount, there remains, say, 10 dollars, as the value of 300 to $350 \mathrm{lbs}$. of meat, being less than 4 cents per lb. for meat of the best quality without bones.

There being such an abundance of cheap meat, and desirous of encouraging the meat preserving industry, the Government of Paraguay has just lately passed a law providing for the introduction free of duty of all things necessary for equipping such a factory, and has provided for the very small export duty of 15 cents gold on the finished product of each bullock or cow.

Paraguay, with about $1,000,000$ inhabitants, is a country so thinly populated that it must take a century or more before it becomes short of pastures for breeding cattle, horses, mules and sheep.

Pretty well throughout the country you can rum a beast to four acres. In fact, that number of acres for a beast is a Goverument minimum. This law is in several States of South America, viz., that the number of beasts is limited on a set amount of land. A wise provision to stop over stocking. Large steamers can go up the River Plate and the Parana as far as Asuncion (capital), 650 miles from Buenos Ayres. 
An extract and camning factory at San Salvador, Northern Paraguay, has been constructed. This is muler American management, amt has a capacity for treating 150 head of eattle daily for extract and 350 for corned beef making. Stockraising is the basic industry of Northern Paragnay, and the North Americans have invested large sums of money in the country lately. A company incorporated at Delaware has spent 1,000,000 dollars in the Paragnayan ('haco, which is practically unknown, and which, when opened up, shonld affort excellent pastmes.

The Frigorifico Paraguay-Carne Conservarla has been organised in Asmeion for the purpose of erecting meat freezing, and canning works. The company intends to erect a plant eapable of dealing with 300 head of eattle per day.

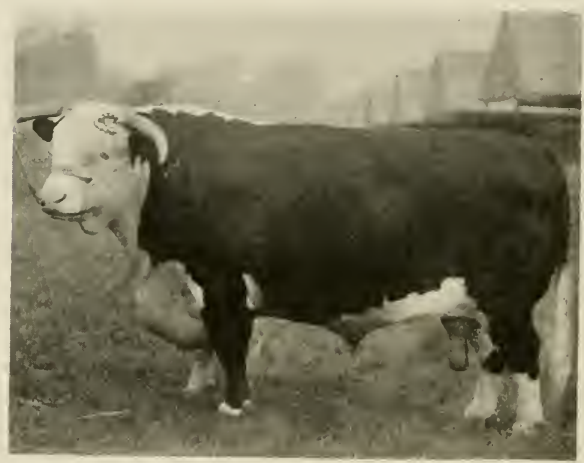

('Hampion Hereford Bull, Gajsborough, Exglish Rotal SHow, 1915. ExhImTED Br Mr. \&. RoBinson. 
The Republic of Chile lies between the Andes and the South Pacific, between latitude 17 deg. $15 \mathrm{~min}$. and 55 deg. $59 \mathrm{~min}$. S., and longitude 66 deg. $30 \mathrm{~min}$. and $75 \mathrm{deg} .40 \mathrm{~min}$. W. Its extreme length is about 2800 miles, the coast line is about 2625 miles, and the average width 90 miles. The Andes form the eastern frontier, with an elevation of 5000 to $10,000 \mathrm{ft}$. above sea-level, and the highest point, 22,422 ft., is Aconcagua, an extinct voleano. The total area is about 291,500 square miles, with a population of $3,500,000$.

There are at present about 2,000,000 eattle and 5,000,000 sheep in the country. In the far south, with Punta Arenas as a centre, there are large flocks of British breeds of sheep and

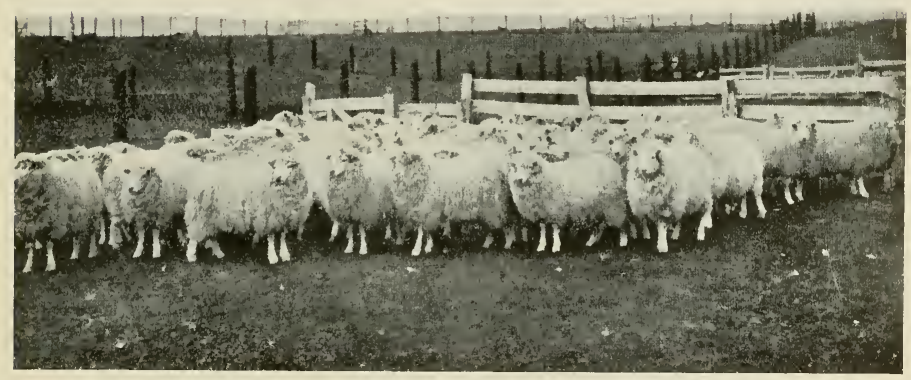

Sheep in Patagonia.

several meat works operating. A very high class of mutton is exported, while the stockowners are British born, and several New Zealanders have settled here.

The northern part of the country is comparatively bare of pastures, but rich in minerals. The central has fertile plains and a temperate climate; here cattle raising is carried on largely. 
In describing the plains of Patagonia recently one writer says: "Shut your eyes and think of yourself with a good nag between your legs going at an easy canter over the soft and grassy Pampa. Above you a turquoise sky and a brilliant sun, below you blue lakes, soft turf and sparkling streams, on the lakes and rivers black headed swans and pinky winged flamingoes, geese, and ducks galore, and now and then a jacksnipe. Small foxes play about you like kittens, and ostriches leg it away a hundred yards ahead of you, their long necks stretched ont, and their wings highly lifted to help them out of the danger zone. The life and place so enchanted me that a year later I became the owner of much camp, 16 leagues, and many sheep. In the middle of my property is a lake five miles by two miles across." The farm is now earning 50 per cent. dividends; and this is a true picture of Patagonia. There is one British company there owning six million acres of land upon which there are 1,500,000 sheep and which regularly imports studs from Australia and New Zealand, or they did until shipping facilities failed them. In Tierra del Fuego the empany owns also $2,250,000$ acres of good sheep country. The manager of this is also a New Zealander like so many men in Patagonia. Chile can be depencled upon for frozen mutton in increasing quantities, but beef eannot be looked for in any but limited amounts.

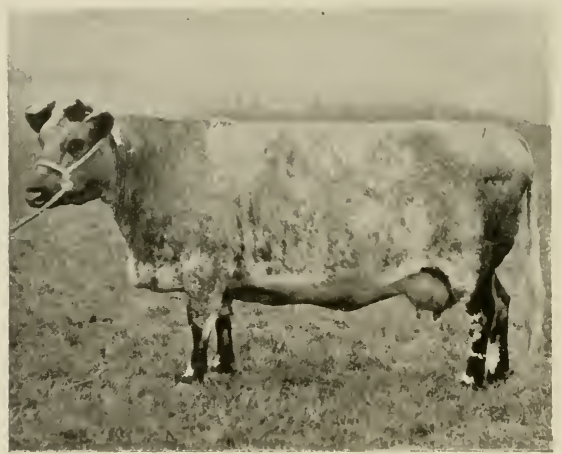

First Prize Shorthorx Cow, CaIracosh JiLt, Exglish Royal Sinow, 1915. Exhibited BY Mr. W. M. Cizalet. 
UNITED STATES OF AMERICA.

The United States as regards live stock is not by any means dead as it was generally supposed to be. It is nearly five years ago that the world was informed that the local demand had overtaken the supply, and that the United States would have to look to Argentina for beef and Australia for mutton with which to feed her own people. What do we see now? The number of eattle marketed during last year was $12,278,000$ in the nine principal markets-it was the largest in the history of the country, but, in spite of this, there were more cattle on the farms at the end of the year than at the commencement. The exports of fresh beef from the United States increased from 6,400,000 lbs. in 1914 to $231,000,000 \mathrm{lbs}$. in 1916. The exports of bacon in the same period increased from $194,000,000$ lbs. to $667,000,000$ lbs. The total weight of all beef products exported from the United States in 1917 was $\$ 11,000,000 \mathrm{lbs}$. The weight of pork products was 1500 million pounds. The average amount per head received for beef earcases and by-products was $£ 19 / 7 / 6$. Of this sum, $£ 17 / 11 / 7$ was paid to the grower, $10 / 8$ for killing, dressing, etc., $9 / 7$ for freight, $10 / 3$ for selling expenses, and $5 / 5$ represented profit. Frozen meat in storage on July 1st, 1918, increased 49.3 per cent., and frozen pork increased 71.37 , as com-

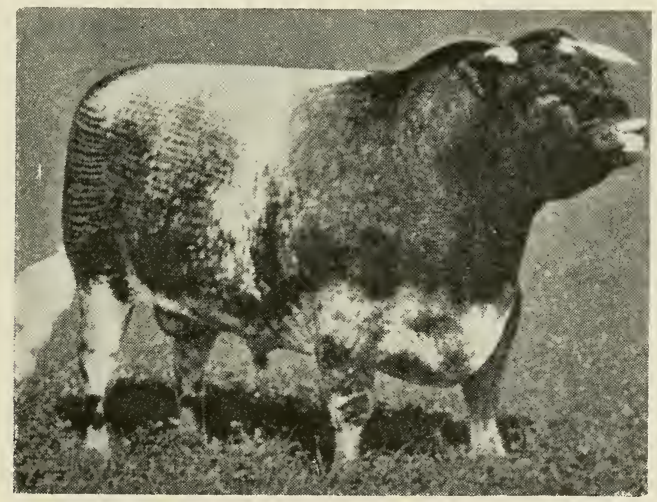

A United States Shorthorn Bull. Champion at thirty-six shows. 
pared with 1917. These renarkable figures show what American stockmen can and will do when called npon in some emergency. The stockbreeder in the Cnited States is not likely to be handieappeel by the Government fixing a maximum price for meat. In fixing a price for fat eattle, should such a thing have to occur, a minimum price should be guaranteed, and the cost of rearing and fattening, of conse, taken into account at the time.

Tho the ordinary mind "price control" earries with it the idea of keeping prices down, while, as a matter of fact, it is produretion and not price that is important at a time like the present. Price control should mean stabilizing and fixing prices on a basis which will insure the greatest production, and thus antomatically prices will come down.

The latest returns published by the Lnited States Burean of Statisties in Jamuary, 1918, estimate the number of cattle at present in that eountry at $66, \times 330,000$ lead, an increase of $3,100,000$ (or t.9 per cent.) over the previous year's total of $63,700,000$ head; and 18.2 per cent. more than the low-water mark in 1913, when only $56,527,000$ heat were recorded. Shesp were retumed at $45,900,000$ heak, as eompared with $45,500,000$ at the end of 1916. The figmres in respect of eattle indicate that stearly progress is being made in replenishing the herds of the Enited States, which had suffered a steady and serions decline for several years prior to the war.

A well-known writer denies that cattle have fallen off in number since 1907 . He gives an increase of $2,000,000$, making total $67.000,000$ head en .Jannary 21st, $191 \mathrm{~s}$.

"In other works, the number of eattle on farms is greater today than ever hefore, and this in spite of the fact that the number sent to market for slanghter in 1917 was the greatest in the history of the combry. It is not generally realised by the publie that the record marketings of both 1916 and 1917 have been aceompanied by a decided increase each year in the mumber of eattle left on farms.'

In a recent letter to members the Ameriean National Tivestork Association says:---

During the year 1917 the number of eattle sent to market for slanghter was the largest in history, and the faet that our supply on Jannary 1st, 1918, showed a substantial inerease. despite the larger slanghter, is convincing avidence that at present there is no shortage of beef eattle. With the exerption of 1916 , the shipment of hogs to market during 1917 was the largest ever reeorded, and the present supply exceeds all previons yearly estimates. 


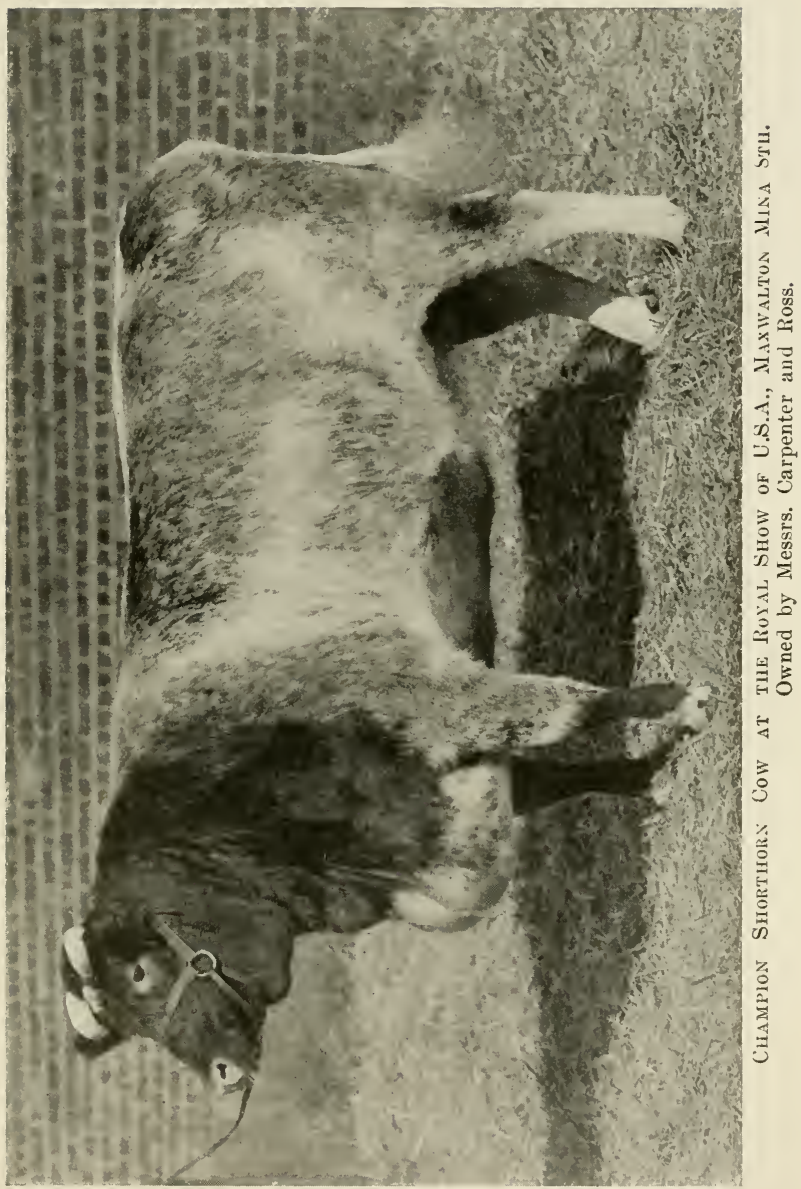


The live stoek industry of the United States responded to the appeal of President Wilson, the Food Administration, and the Department of Agriculture for increased production. At present there are ample supplies of meat food animals in the United States to take eare of all probable demands from om allies, to supply our army and navy generously, and for a normal domestic consumption. This supply has been produced under exceedingly adverse conditions as to labour, cost of animal feeds, \&e. The result is a great credit to all those engaged in the live stock business.

More and more, as the war progresses, do the greater production of live stock and the conservation of meat become pressing necessities. While there has been a numerical increase in livestock in the United States in 1917, the tendency of farmers to ship their eattle and hogs before they are properly finished, due to advanced cost of feed and eagerness to get high market prices, has brought about a decreased noundage per animal.

The records, borne out by those of the industry in general, show a loss of weight of approximately 10 per cent. in 1917 as compared with 1916. This offsets the increase in numbers.

During 1917 Armour \& Company paid to livestock producers in the United States alone the sum of 341.743.275 dollars $(£ 68,348,655)$ for cattle, hogs and sheep, or $109,167,133$ dollars $(£ 20,000,000)$ more than a similar poundage would have cost at the 1915 seale of prices. This additional sum necessarily had to be eollected from eonsumers to be turned over to moducers.

Obvionsly, we must look first to the producer. For him the Govermment has largely taken the speculation ont of production, and inasmuch as his gains are assured for years to come, he can combine patriotism with profit by increasing and improving his herds.

He must breed for quality that will produce maximum weight in the shortest time. Every mused nook and corner of his farm should grow feed for his animals. Surph dairy calves should be fed no longer than is neeessary to bring them to the veal stage, thus conserving feerl, while beef calves should he saved and brought to earlist maturity.

An excellent article by Mr. W. R. Goodwin was published recently in the Shorthorn. World on the "Improving Power of the Shorthorm." This applies to all native stock everywhere.

Sars Mr. Goodwin: The student of beef cattle breeding will conclude that the Shorthorn is not only the ensmopolitan breed, but also the universal improver of heef stocks. This fact carries 


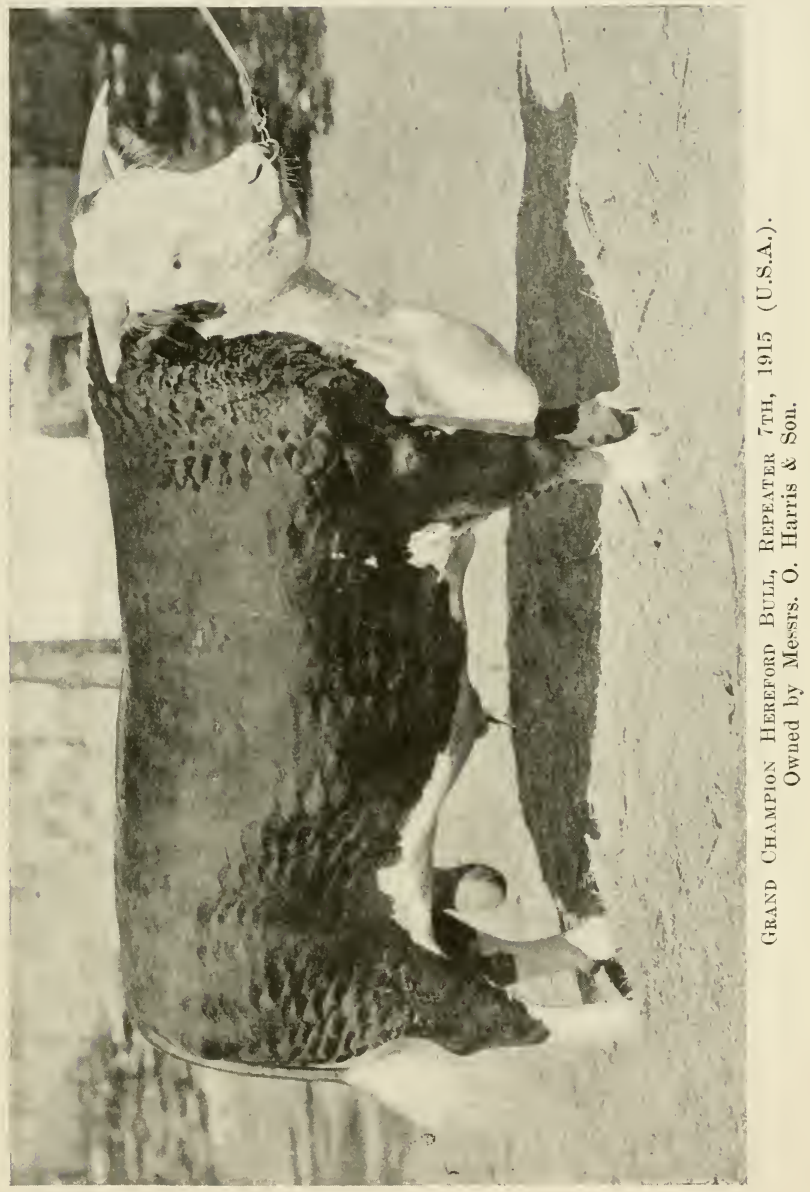


a tribute and imposes an obligation. (In some countries the Hereford, Angus, and Devon will be found more suitable; it greatly depends on rainfall and condition of conntry and pasture.) Native stoeks lack beef form-that form which in the feed lots of the world has been proved to grow rapidly, thrive easily and produce the desirable euts of beef in the greatest proportion to wastes. Scale, thrift, and wide and level form are the requisites of a profitable beef-producer. The grower must have weight at the finish, the packer must have flesh that will ent profitably. The fomders of the Shorthorn breed lived close to the pasture, the feed-lot and the butcher, evolving in their ideals a type that met the dual requirements of the producer and the purveyor of prime beef. Wherever the blond touches native stocks it instantly register's its leavening influence, and the mimproved, the scrub, becomes a visibly homogeneous part of the great tribe of thrifty beef-makers that wears the colours of red, white and roan. The appeal can be made world-wide and ever is it answered in unison. The eosmopolitan elaraeter of the breed is proved in its distribution that ranges more widely than that of any other improved race of eattle, and its power of nuiversal betterment is registered on all stocks of whatever origin or type it tonches.

The first cross tells the tale. The Shorthorn bull brands indelibly his offspring in size, levelness, ferding quality. The history of cattle improvement, on whatever eontinent it is studied, proves the vital influenec of Shorthorn hlood in its foundation-laying first eross. On that foundation other breeds have built, to the great satisfaetion of breeder's who have skilfully crossed and carefully grazed and fed, and these breeders, wide-visioned, broad-ganged, fair-minded men, right cheerfully accord credit to the shorthorn breed for its fomdation work.

No breed has so essentially earned the title of the miversal improver of natire stoeks as the Shorthorn. The blood of this breed is "first aid to the injured," blending kindly and effectively for the elimination of the molesirable eharacteristies of the primitive types, and adding size, framework, levelness of flesh and aptitude to fatten. Long years has the Shorthorn breed held this honomed position, from whieh it will not be displaced by any other breed while native stocks of any country or clime require the union of blood which will lay the fomdation for profitable feeding. It is a place of pride and a position of responsibility. 


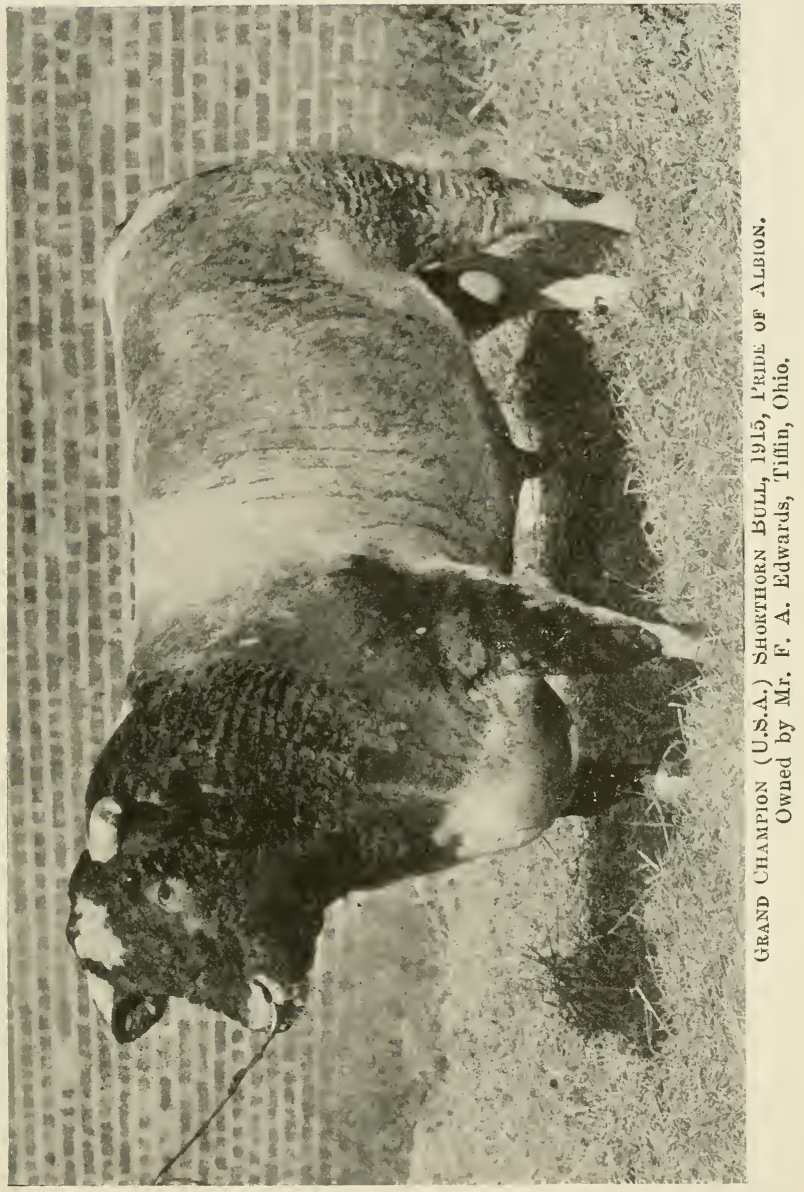


The obligation laid on the breed is no less conspicnous, indeed it is all the more inexorable because of the unchallenged success of the breed in the work of improvement. The wide-rolling, richly-grassed ranges of America is western regions have produced and fattened the beef of the past quarter of a century. some of it has been finished in the rich central valleys; mueh of it has been grown on the grasses of the plains. In the development of this land vital changes are of ahnost constant record. With the transformation of open range to fenced pastures and thence to farms, all in tonch with the industry are familiar. The country suddenly awakened and found itself short of beef.

Time was when the farm cow of America supplied the beef and the milk, and that cow was of shorthorn blood. The advance in food values and the competition of the range herds, which laid down calves off free grass at central markets at prices with which farm-raised calves could not compete, drove the cows that bred feed-lot calves largely from the farms of the central west. A cow could not be kept for the value of her feedyard progeny. Farmers drifted with the tide, which has now receded and left many of them aground.

Conditions have changed back again. Angmented population, coupled with decreased beef supplies from the ranges, opens the door to profitable farm breeding of beef ealves. This may be done on the cheaper, rough and broken lands with a purely beef eow, but it is readily accomplished on the richer lands of higher value with the real farmer's cow, the cow that more than pays her way at the pail while producing a prime feed-lot prospect. That cow has been, still is, and will continue to be the Shorthorn dual-purpose cow, unless the obligation which lies at the door of the Shorthorn Association and Shorthorn breeder's is deliberately shirked. It may have been overlooked in times past. Men of great faith kept the fires burning on the original altars, however, conscions and eonfident that over vast stretches of our farming country the dual-purpose cow hat her place despite the competition from the open ranges, and convinced that the day would come when a great light would shine on the understanding of American farmers, and they would turn eagerly to the big, level-framed, placid-eyed red, white or roan cow, possessed of the dual capacity for milk and meat production, according to her development and education, and standing as a foundation-stone of profitable American agriculture. The obligation to restore that cow to her place of prime importance 
in profitable small farm production rests on adherents of the Shorthorn breed. It never more insistently demanded recognition than in this time of world-throes, and in the coming period when the back of mankind will be bent under the burden of a torn world's restoration. 


\section{CANADA.}

Canadian farmers are making strenuous efforts to augment their meat supplies, the number of eattle in 1917 being abont $8,000,000$, against $6,600,000$ in 1916-an inerease of 20 per cent. sheep also inereased from $2,022,941$ in 1916 to $2,369,358$ in 1917 . The Government is assisting the farmers in every way to increase their live stock.

The Hon. Martin Burrell (Minister of Agriculture), in a statement issued recently, outlines a eo-operative plan reaehed between the department and the Canadian railways. The aim of the scheme is to prevent depletion of Canadian breeding and feeding stock, insure the feeding of live stock in Canada, and to secure the return of feeding and breeding stock to the farms. It comprises-

A re-distribution policy, whieh will provide for the movement of stoek from areas where feed is light to areas where feed is plentiful.

Free freight poliey in commeetion with the transportation of breeding eattle and breeding sheep.

Fifty per eent. rebate of the freight rate on ear-load shipments of feeding eattle from Winnipeg to eountry points in the eastern provinees.

Free shipments of ear-loads of breeding sheep and lambs from Toronto and Montreal to the West.

Just imagine a proposal sneh as this on the State-owned railways of Anstralia, where stud stock are more heavily freighted than fat stock when being conveyed. The "democratic" population of the big eities would raise a ery that the farmers were being favoured at onee, instead of having brains to understand that the more the produeer is assisted, the better it must be for the consumer.

The Goverument of New Brunswiek (Canada), through its department of agrienlture, is giving publicity to a proposal formulated under reent legislation by which it is hoped the pastoralists of the Provinee will be encouraged to devote more attention to sheep than has been dome in the past. Briefly, the Govermment's proposal is this: 'Throngh an arrangement made with the ehartered banks, assistanee will be given where it is needed to all farmers to buy sheep. The department of agrienlture will not only arrange to buy sheep for the farmers, but will also buy from the farmers any good breeding stoek that 


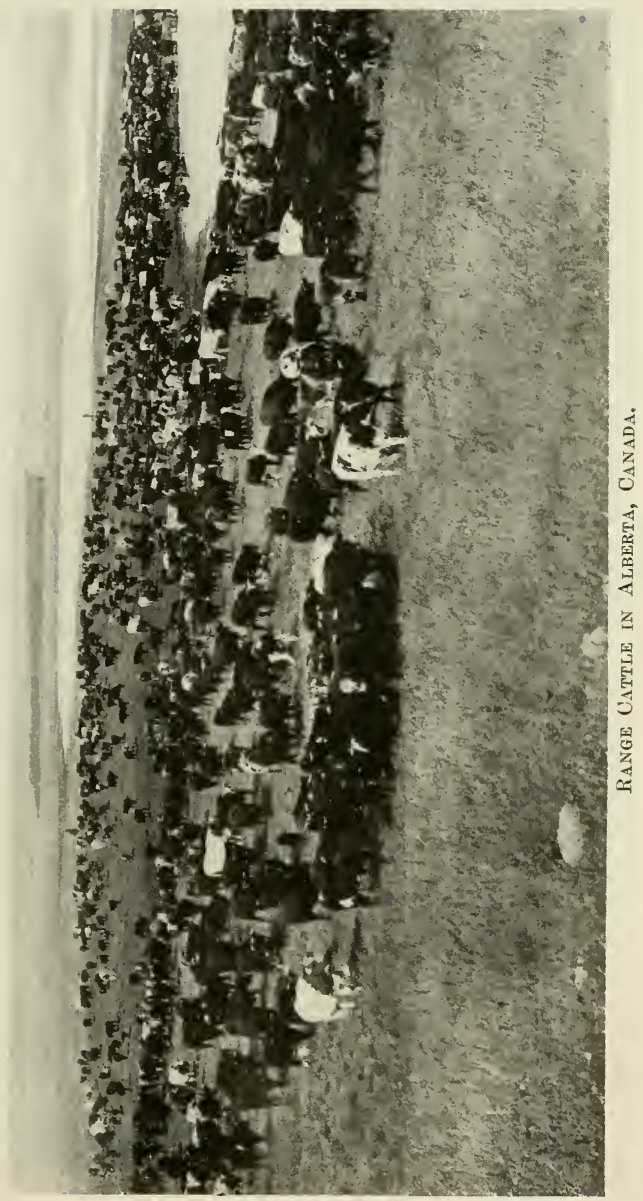


may be available. If a farmer needs credit, he may consult a local banker, and from him obtain the necessary forms. If sheep are not to be had in any given locality, a farmer there resident will be given an opportunity to purchase through the banks and the agrienltural department in another part of the Province.

The Canadian Minister of Agriculture, in a pamphlet dealing with beef-raising, says: "Canada recognises that to succeed in the production of beef the requirements of the purchaser must be complied with. The standard of the beef market has changed greatly in recent years. Not many years ago, the best market demanded large, heavy, thick bullocks weighing 1800 to $2000 \mathrm{lb}$., but the demand has changed, and cattle of that description are no longer in demand. The bullock that commands the highest price is a compact, well-finished animal weighing not more than $1500 \mathrm{lb}$. on foot, and if he weighs only $1200 \mathrm{lb}$., he will command the highest market price, provided he has the form, quality and finish. Even the thousand-pound 'baby beef' is looked for by the man with the money on this side of the Atlantic, but such eattle are not shipped abroad. This change is greatly to the advantage of the producer, as, other things being equal, the younger the animal goes to market, the less is the cost of food and the greater the profit to the producer. 
"The British market demands eattle of moderate weights, good quality, and carrying sufficient fat in connection with the lean meat to secure a high degree of excellence without waste. To secure delicate flavour and tenderness, a certain proportion of fat is necessary, and this should be incorporated with the flesh or lean meat rather than appear only as a covering to the muscles. The great serret in prodneing a carcase of beef is to treat an animal in such a way that the fat grows with it during the entire period of its lifetime. It is unfortunately the too common

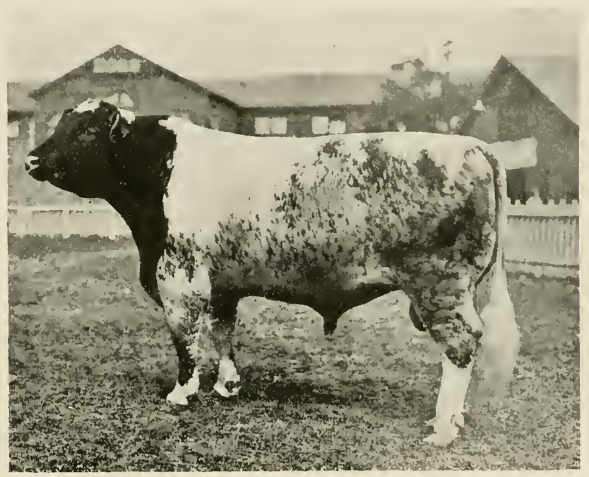

IMPORTED SHORTHORN BULL, GaNFord MARquis.

practice of Canadian beef raisers to produce all the fat that an animal earries in the course of a few months. Much of the fat put on it this way is deposited on the outside of the carcase; it is largely wasted as it is useful for little else than tallow. The carcase that dresses out showing specks and streaks of fat throughout the lean tissue commands the highest price. Such beef is regarded as much of a delicacy as the finest turkey or lamb. The only way to be sure of prime quality is to maintain the animal in good condition by a system of liberal feeding from 
birth to maturity. Then the finishing period is comparatively short, and the carcase produces the highly desirable marbled beef.

"It will be gathered that the requirements of both the feeder and the butcher must be considered in the selection or breeding

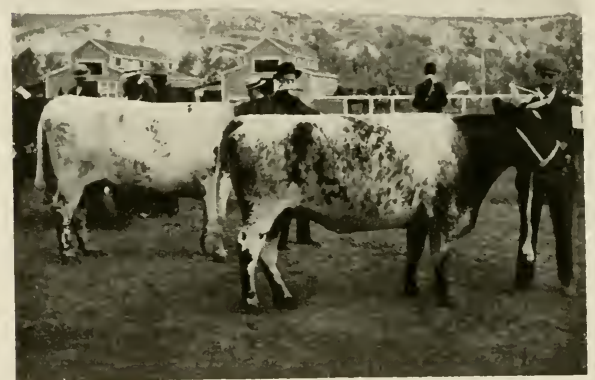

Shorthorn Cows at Eddonton Exhibition.

of the most profitable steer. The feeder must have in his animal good bone, roomy paunch and a leep broad chest, while to the butcher's steer these parts have no particular value, becanse it is in these that much waste occurs. Giving the requirements of both feeder and butcher due consideration, a standard of perfection has been built up, in which each part of the animal is afforded a numerical value according to its importance. The following score-card agreed upon by many of the foremost demonstrators and instructors in animal husbandry, will be of value to students who desire to become proficient in the judging of beef cattle:- 
Score-CARd for Beef Steer.

General appearance, 40.

Weight, according to age

Form, straight topline and underline; deep, broad, low set, stylish

Quality, firm handling, hair fine, pliable skin, dense bone, evenly fleshed

Condition, deep even covering of firm flesh, especially in the regions of valuable cuts ..............

Head and neck, 7.

Muzzle broad, mouth large, jaw wide, nostrils large 1 Eyes large, clear, placid ............... 1

Face short, expression quiet .............. 1

Forehead broad, full .................... 1

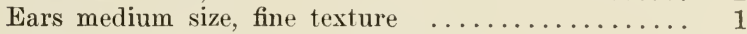

Horns, fine texture, oval, medium size .......... 1

Neck thick, short, throat clean...$\ldots \ldots \ldots \ldots \ldots .1$

Forequarters, 8.

Shoulder vein, full ................... 2

Shoulders, covered with flesh, compact on top, smooth 2

Brisket advanced, breast wide $\ldots \ldots \ldots \ldots \ldots \ldots .1$

Dewlap, skin not loose and drooping .......... 1

Legs, straight, short; arm full, shank fine, smooth.. 2

Body, 32 .

Chest, full, deep, wide, girth large, crops full ...... 4

Ribs, long, arched, thickly fleshed ........... 8

Back, broad, straight, smooth, even $\ldots \ldots \ldots \ldots \ldots .10$

Loin, thick, broad $\ldots \ldots \ldots \ldots \ldots \ldots \ldots \ldots \ldots$

Flank, full, even with underline $\ldots \ldots \ldots \ldots \ldots \ldots .2$

Hindquarters, 13.

Hips, smoothly covered, distance apart in proportion with other parts

Rump, long, wide, even: tail head smooth, not patehy 2

Pin bones, not prominent, far apart .......... 1

Thighs, full, deep, wide $\ldots \ldots \ldots \ldots \ldots \ldots \ldots \ldots 2$

Twist, deep, plumb $\ldots \ldots \ldots \ldots \ldots \ldots \ldots \ldots{ }_{2}$

Purse, full, indicating fleshiness $\ldots \ldots \ldots \ldots \ldots \ldots 2$

Legs, straight, short; shank fine, smooth ........ 2 


\section{Mlaking Baby Beef in Alberta.}

Although considerable numbers of three and even four year old grass-fed steers still tome from the ranges of Alberta, the rapidly-inereasing production of grain and eultivated lodders is tending to bring about the marketing of eattle at a mueh earlier age than was usual under the old conditions. For some years past, sales of two-year-old fat steers, and, unfortunately, also heifers, have been increasing in frequency, but baby beef has until now been unknown on the Alberta market. The following brief statement of an experiment in the fattening of last year's calves on the Canadian Pacific Railway supply farm at Strathmore should, therefore, be of interest.

Recently, forty-four steer calves, mostly of Hereford anil Shorthorn breeding, which had been running with their dams from birth, were weaned and placed in feeding pens holding from eight to fifteen head, in the big barn at Strathmore. A few were March ealves, but the great majority were from six to eight months old. Some were of excellent beef type and quality, but, as heyond taking the best of those which happened to be on hand, they were not specially selected, a number more or less lacking from the feeder's standpoint. Calves quite as good, or even better, are readily procurable in Alberta every fall. They averaged in weight on 23rd November slightly over 486 lbs., being searcely as good in flesh as they would have been had the weather in October and November been more favourable than it was last year. Circumstances also prevented the carrying out of a very valuable feature in the production of baby beef, namely, the teaching of the calves to eat choj) when still with their dams, thus holding the milk flesh and forestalling the check at weaning, unavoidable otherwise. Throughout the feeding period, the calves had all the fodder they would eat up clean. At the beginning, a little restriction was put on the quantity of grain given, 2 lbs. per head per day being the amount started with. By the end of the first month, this quantity had been more than doubled, between 6 and 7 lbs. per head per day being the grain ration from the beginning of full feed until the calves were sold. The grain mixture used at the start was two parts of oats, one part of barley, and one part of bran. About the 1st of February the barley was increased to half the ration, and the same proportion of bran continued. A small quantity of frosted flax, costing a halfpenny a pound, was used after the 1st of January, a total of 60 bushels being fed from then until the end of April. All the grain required 
was valued at the market prices prevailing from the same at the end of Oetober-oats at $1 / 11$, barley $2 / 10 \frac{1}{2}$ per bushel, and bran $£ 4 / 14 / 8$ per ton. With the grinding, the grain figured to approximately ${ }_{4}^{3} \mathrm{~d}$. per $\mathrm{lb}$. Green oat sheaves furnished the bulk of the fodder, about $2 \mathrm{lbs}$. of oat sheaves to $1 \mathrm{lb}$. of hay being the proportion. The oat sheaves were valued at $£ 1 / 8 / 10$ per ton in the fall, and the hay $£ 2 / 13 / 6$ per ton for alfalfa and $£ 1 / 8 / 10$ per ton for the prairie nay. The quantities used of each made the eost of the hay approximately $£ 2 / 1 / 2$ per ton. The barn was well lighted and ventilated, and water and salt were available at all times.

The price realised was $4 \mathrm{~d}$. per $1 \mathrm{~b}$., with a eut of $\frac{1}{2} \mathrm{~d}$. per $\mathrm{lb}$. on the fifteen light ealves, and 5 per cent. shrinkage on the whole, as they were weighed out of the barn. This figured out as follows :-

Cost.

44 calves, total weight 21,404 lbs. $£ 264 \quad 411$ $5+, 068 \mathrm{lbs}$. oat sheaves $\ldots \ldots \ldots$... $38 \quad 18 \quad 9$ 43,680 lbs. hay $\ldots \ldots \ldots \ldots \ldots .44 \quad 18 \quad 9$ 33,859 lbs. ehop . ......... $104 \quad 10 \quad 0$ 6903 lbs. bran ............ $16 \quad 6 \quad 8$

$\pm 468 \quad 19 \quad 1$

RETURNS.

29 ealves, $24,285 \mathrm{lbs}$. at $4 \mathrm{~d}$. . ... $£ 424 \quad 14 \quad 9$

15 calves, 10,595 lbs. at $3 \frac{3}{4}$ d. . . . $163 \quad 10 \quad 0$

$\begin{array}{llll}£ 588 & 4 & 9\end{array}$

Less 5 per eent. shrinkage on 34,880 lbs. $\ldots \ldots \ldots \ldots \ldots .29 \quad 8 \quad 3$

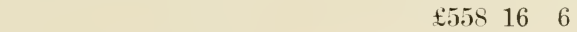

Deduct eost as above ........ $468 \quad 19 \quad 1$

Net profit $\ldots \ldots \ldots \ldots \ldots \ldots . \overline{£ 89 \quad 17 \quad 5}$

Cost per lb. of gain, $3 \frac{3}{4} d$. 
The ealves were purchased, and were weighed out on the 6 th of May, having been $16 t$ days on feed. Forty-four head weighed a total of $34,880 \mathrm{lbs}$, an average of over $702 \mathrm{lbs}$. The gain made by each calf averaged about $305 \mathrm{lbs}$. for the period. A lot of eight Herefords made the largest gains during the feeding. On 6th May this lot, averaging just under twelve months of age, weighed $950 \mathrm{lbs}$. each. Another lot of fifteen, averaging in age under eleven months, weighed $798 \mathrm{lbs}$. each; a third lot of six head of the same age, 786 lbs.; and a pen of fifteen of the youngest ealves $706 \mathrm{lbs}$.

This out-turn shows a net profit of nearly $£ 2 / 1 / 2$ per head. Considering feed prices this year, this may be considered a very fair return. Under ordinary conditions, with grain worth about $3 / 1$ per ewt. instead of $6 / 2$, with hay at least $8 / 23$ per ton cheaper, and with the price of the finished product as high as that realised-for these calves sold at a moderate price, considering their quality and finish-there would have been a net profit of $£ 3 / 9 / 11$ per head. Careful observation of these calves during the winter confirmed the following practical conclusions, about which there is perhaps nothing very new :That feeding ealves for baby beef pays even under prevailing high prices for feeds and moderate prices for beef. That the best gains are made by calves about eight months old at the beginning of the feeding period. That it pays to select the calves carefully, taking only those that carry a fair amount of natural fleshing and that have never had a set-back. That beef type and natural fleshing are the controlling factors in determining the length of time and quantity of feed required to fit a calf for the block; calves of dairy type and calves of beef type lacking somewhat in fleshing at the start will not make gain comparable with that made by deep-fleshed, low-set, thick, blocky calves that have never had their growth checked-calves of the thin-fleshed order incline to belly-fat, and do not cover deeply with flesh on the back and loin. The last conclusion is that quietness in the food lot, gentleness in handling the calves, and careful attention to feeding regularly have nearly as much to do with the final results as has the feed. 


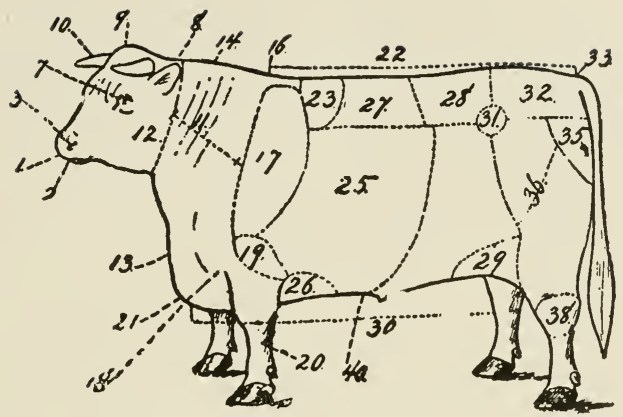

Points of Beef Cattle. Side View.

1. Muzzle.

2. Mouth.

3. Nostril.

7. Eye.

8. Ear

9. Poll.

10. Horn.

11. Neck.

12. Throat. 14. Top of
17. Shoulder.

19. Point of shoulder.

19. Arm.

20. Shank.

21. Brisket.

22. Topline.

23. Crops.

25. Ribs or barrel.

26. Foreflank.

r 27. Back or chine.

28. Loin.
30. Underline, or bottom line.

31. Hip, point of hip, hook bone.

32. Rump.

33. Tailhead.

35. Buttocks.

36. Thigh.

38. Hock.

40. Navel.

16. Top of shoulder. 29. Hind flank.
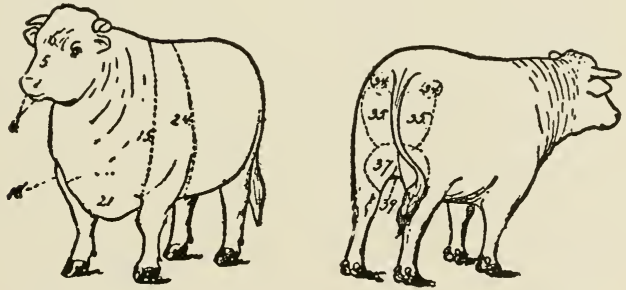

Points of Beef Cattle. Front and Rear Views.

4. Lips.

6. Face.

6. Forehead

15. Neck vein, der vein.
18. Point of shoulder. 37. Twist.

21. Brisket.

24. Girth.

34. Pin bones.

35. Buttocks. 


\section{MEXICO.}

The Republic of Mexico has an area of 772,652 square miles, and is roughly 800 miles from east to west at its widest point, and 2000 miles from north to south, thus being equal to New South Wales, Victoria, and South Australia, or, say, a quarter of federated Australia.

Nexico has about 6,000,000 cattle and 4,000,000 sheep, and with its great advantages in railway communications with its great northern neighbour, the Lnited States, and its excellent shipping facilities on the Atlantic side, should, with an improvement in its quality of stock, soon become an important factor in the export of frozen meat.

There seems to be a considerable confusion in the minds of many between Mexico and New Mexico. Mexico (or, as it is generally called, Old Mexico), after the termination of the war with the United States of America in February, 1848, ceded to that Republic as war indemnity all lands north and west of the Rio Grande River ; included in this was the territory called New Mexico.

Mexico as a country has been endowed by Nature with an over-abundant supply of natural resources, rich in minerals, silver in almost every mountain, copper and lead are plentiful, gold also being found in fairly large proportions. The northern States are phenomenally rich in immense coal beds, and in the States of Durango and Nuevo Leon are found almost solid mountains of iron. Turning to the other sources of its wealth, we find large tracts of splendid agricultural and grazing lands. The formation of the country is peculiar. It rises in three distinct tablelands from the coast; first are the hot lands (tierra caliente) near the coast, where all tropical growth is ahundant in fruits and forests; then as the land rises from 2000 to $5000 \mathrm{ft}$. above sea-level, comes what is called the temperate zone (tierra templada). Here it is eternal spring. Then as the land gets higher up to the Sierra Madre comes the cold belt (tierra fria), cold only in comparison with the other warmer parts, as snow is seldom seen except on the high mountain peaks, but where frosts in winter prevent the growth of the more tropical fruits and vegetables. The two latter zones are the great stock-raising portions of the Republic, healthy alike for man and beast.

The system of rumning stock in Mexico is very much after the old style that was in rogue in Australia fifty years ago. Sheep and goats are shepherded in flocks of from 1200 to 2000 , 
the shepherd (pastor) has no dog to help him, but breaks in his flock to turn at certain cries; at night he brings his flock to the camping ground (majada), and so well trained are they that wherever they see the shepherd's fire they coil down and remain till morning, unless disturbed in the night by wild animals, when it is the duty of the shepherd to get round them and bring them back to their eamping ground, the coyote (wild dog) being most troublesome. The shepherd has no tent or hut, merely a piece of oilcloth to sleep on or to keep his provisions dry : hence the shifting of camp is an easy matter, and a flock never remains on one camp more than a few nights - a decided advantage. Over every four shepherds there is a "vasiero" (overseer), whose duty it is to count sheep, carry water and rations to the shepherds, and look for any stray sheep. Over every four "vasieros" there is a "mayordomo" (head man), who has the general supervision over all, and issues rations, ete.

Lambing is quite a laborious undertaking. First, all ewes in lamb are earefully drafted out and run in small flocks not $6 \mathrm{x}$ ceeding 1000 ; each day's lot of lambs are kept apart in small "atajos" (flocks) until the lambs are well mothered, when several of these "atajos" are joined; the lambed flocks ave never larger than 300 until the lambs are marked.

All this necessitates a number of extra hands, but as labour is very cheap, from $18 /$ - to $20 /$ - a month, it pays to do it, and usually good percentages are raised.

Shearing is done in temporary sheds of boughs, with mother earth as a floor, swept more or less carefully (generally less) for the occasion. One of the shearers being appointed captain, the rest bow implicitly to all his commands, and it is to him the owner of the sheep brings all complaints, such as improper shearing, etc. The shearer's' tallies are kept by each man receiving a check as he releases his shorn sheep. The owner pays a lump sum on the grand total as counted out by him to the captain, who arranges with the men their individual amount. The usual price for shearing is $10 /-$ a hundred, and the shearers find themselves. On very large ranches it is less, even as low as $8 /$. $\quad$ Wool is packed into large sacks by the simple process of tramping it in, fleece, pieces and bellies all in one mass, these sacks averaging about $300 \mathrm{lbs}$. Shearing twice a year is universal, and it is claimed by this method fully $1 \frac{1}{2}$ lbs. per sheep more is obtained. Buyers usually come round at shearing and purchase delivered at nearest railway station. Scab, the sheepman's greatest curse, is still prevalent in Mexico; wherever the 
owners of shcep are Inexicans, they either do not realise that it can be cured, or are too indolent to stamp it out by united effort; where sheep are owned by Australians, English, or Americans, the Hocks are usually elear from this parasite.

Goats are largely raised, as they are most prolific, and a ready sale for their eareases is always to be had at from $4 /-$ to $5 /-$ each, whilst their hides are shipped in immense quantities to America for shoemaking, and realise locally about $2 / 6$ each.

By far the pleasantest branch of the stock business is in breeding eattle, and this, after goats, is the most lucrative. Formerì they were rum in a haphazard style on free range, and all owners together, but now as land is being bought up and fenced, the small men with no land are being squeezed out, and gradually the cattle industry is getting into the hands of the wealthier classes. The system of working the eattle is a happy combination of the best methods of all countries; properties are bought, fenced by barbed wire, and subdivided; stock-yards, tanks, and wells put down, and the more improved strains of Hereford, Durham, and Polled Angus are being introduced. The markets for fat stock are the principal cities of Mexico, Yncatan, Cuba, and the United States of America. It is a very healthy place for cattle. I have never seen or heard of a case of pleuro or foot and mouth disease, and the calvings are usually of a high percentage, averaging over 70 per cent. Horses do very well, but there is little sale for them apart from those required for the Mexican eavalry. Mule-breeding is, however, a most lucrative business, and splendid animals are obtained by using American jacks (donkeys) of from 15 to 16 hands put to rative mares. The demand is very keen for mules, unbroken, three years old.

As to the price of land, it is very varied, there being, as in all countries, good, bad, and indifferent. Land that will carry a bullock to 10 acres ean be bought, fenced and improved, at from $6 /-$ to $7 /-$ an acre, according to its location to railways or large cities. Unimproved land of about the same carrying capabilities, but further back, ean be bought at from $2 /$ - and upwards, while some parts sell as low as $6 \mathrm{~d}$. an acre in large tracts of poorer (ruality. Irrigable lands are much higher, ruming from $\mathfrak{£ 6}$ to $£ 10$ an acre.

The star of Mexico, as a meat exporter, is waxing, and it promises to shine still more brightly, as among the countries of the world few possess such a combination of advantages 
for successful stockraising and cheap-meat production. About three-fourths of the whole area is considered suitable only for grazing and agriculture, and the bulk of it is chiefly valuable for grazing. American rancher's, who have been erowded out of their own country by the encroachment of settlers and the handicap of the now almost prohibitive land values in the United States, have realised the great field awaiting them in Mexico, the richness, the vast extent, and the low cost of the splendid pastures, and so it has come to pass that enterprising men, with money and experience, have been migrating from their own country to where they can obtain land at a fifth of the price per acre similar land would command in Texas.

Although the quality of Mexican livestock is at present inferior to that produced by the United States and Canada, rapid progress is being made, and there is an increasing percentage of cattle suitable for export as refrigerated meat, while for the tinned-meat trade there is an ample supply. When it is borne in mind that Mexico is equal in area to the United Kingdom, France, Germany, Spain, and Portugal, and that the greater part of it ean be most profitably utilised by the production of livestock, it can easily be seen that there are marked possibilities of a big trade. The rainfall over a greater part of the territory is sufficient to ensure the growth of nutritious grasses, and the quality of fat produced by these grasses compares favourably with the production on the prairies of Canada, the United States, and Argentina.

The Mexican National Packing Company, Limited, is about the most favoured meat company in the world. Mexico was noted as the possessor of the most faulty and out-of-date system of dealing with meat that existed in any country of equal importance, and in order to place it on a more sanitary footing, and to enable the people to be provided with wholesome meat, the Mexican Govermment granted the packing company very extensive and valuable concessions. The people of Mexico now can purchase clean refrigerated meat, and they can purchase it at a lower price than they formerly paid for a poorer quality of meat handled in an insanitary manner.

Taking everything into consideration, the improving quality of the cattle, the favourable climatic conditions, and the short average rail haul to the packing houses, it is tolerably certain that before long Mexico will be counted as one of the world's big meat suppliers. It only awaits a more settled government, which 
no doubt will come after the war, when the German influence is removed, to make this one of the most important and the closest big beef supply to the British Empire and the United States.

I shall never forget the trip I made some years ago from Vera ('ruz to the City of Mexico. The railway most of the way rises five fect in every hundred, and the scenery everywhere is magnificent. As Esperanza, near the top of the range, we, as usual, broke our journey for the night, when we were banqueted by the native population. We passed en route the magnificent mountain of Orizaba, and from then on travelled over a vast grassy platean to the capital. We were eonveying big consiguments of Mexican dollars to the coast for shipment, per Royal Mail Steamers, to China. They were eventful and exciting journeys indeed. 
This Republic is bounded on the south by Brazil, on the north by the Carribean Sea, east by the Atlantic, British Guiana, and Brazil, and west by Colombia; it is 700 miles north and south, and 650 miles west and east. It has a population of $2,600,000$.

The area of Venezuela is variously given between 394,000 and 600,000 square miles, but the larger figure includes territory whose possession is not definitely settled, or which has only been approximately surveyed.

The great Llanos or plains are a marked physical feature of Venezuela. At one time they were the home of great herds of cattle and horses. They are covered with rich natural grass, with some wooded areas, and the general elevation above sealevel is about $400 \mathrm{ft}$. Dne to the flat and uniform surface, the Llanos are inundated in the rainy season from the waters of the Orinoco, to the exent of thousands of square miles, or connected with a network of connecting channels.

It is a magnificent cattle rearing country, and at the present time possesses abont 2,000,000 head, mostly small and wiry. It is a country that should easily run $20,000,000$. It has already exported frozen beef, and promises to increase its shipments.

The plains are thickly studded with low trees, and the Orinoco, the great water highway of Venezuela, is fringed in its lower course with magnificent evergreen forests. Tenezuela is the home of the cow-tree, which vields large quantities of nutritions, thick milky juice. Countless herds of cattle once were supported on the grassy Llanos, bnt there has been a great decrease in the numbers through the murrain and other canses. The Llanos or pampas occupy a fourth of the country lying between the Orinoco and the northern mountains, with undulating plains of long grass broken by numerous clumps or belts of low-sized trees. It is almost unnecessary to say that the lower lying portion of Venezuela consists of unhealthy swamps with luxuriant vegetation, accompanied by tropical fevers. 'The Llanos have the rainy season in the summer months.

In the province of Apure the pastures are abundant all the year, a great number of horses, mules, and asses feeding on the plains. The most elevated part, in the province of Trujillo, has declivities with fine, well-wooded valleys, and between them several plains descending in gentle slopes, covered with fine 
pasture. Sheep are only numerous in the mountains and hilly tracts, eattle, horses, mules, and asses being r'un on the plains or llanos, hence their name of eattle-plains. The greatest heat is experienced on the eattle-plains; on that undulating country the thermometer ranges between 83 deg. and 95 deg., and the mean annual heat, 83 deg., is greater than that of the Equator at the sea-level. At the lower end of the Rio Apure the heat is intolerable during the dry season, as the north-easterly wind passes over the strongly-heated surface of the tableland before it arrives at the low plains of the Apure, and thus the air feels as if it eame from an oven, the same as on a "brickfielder" day in Australia. The heated sand, which is suspended in the air and carried forward by whirlwinds, renders it still more disagreeable. The heat of this part is between $86 \mathrm{deg}$. and 98 deg., the mean annual heat being 91 deg. The heat is much less in those parts which are eovered with forests; there the mean temperature is only about 77 deg., and the thermometer ranges between $73 \mathrm{deg}$. and $82 \mathrm{deg}$. In the dry season the heat is greatest from January to Mareh, but in the wet, from July to December, the heat is frequently accompanied by heary thunderstorms, partially clearing the air. At this time of the year, rains are generally abundant and continual. By an estimate it has been found that, on an average, it rains three hours every day, generally towards evening; about midsummer it sometimes does not rain for a whole month. This season is ealled the Little Summer of St. John. In the extensive forests of the southern district the annual amount of rain is between 90 and 100 inches. The rain which descends in this tract in one day frequently exceeds what falls in a whole week in the southern countries of Europe during the most rainy period of the year. On the lower grassy plains the annual rainfall varies between 70 and 80 inches. On the higher region of the Andes it rains all the year round, espeeially after sunrise. On the paramos or mountains (more than $10,000 \mathrm{ft}$. above the sea-level) it snows and hails continuously, and the air is always charged with a thick fog, which disappears at midnight, but returns at sunrise.

Between the Rio Apure and the Rio Meta, both affluents of the Orinoco, are the llanos of Apure, containing the lowest portion of the eattle-plains. The lowest tract is only $224 \mathrm{ft}$. above the level of the sea, though more than 500 miles distant from that part of the ocean to which the waters descend. This plain is so level that the eurrent of the Apure and Meta is imperceptible, and the least rise in the Orinoco causes their waters to. 
How back. No rock, no stones, not even a pebble is seen on these plains. The soil consists of a mixture of sand and chalk. It is covered with very nourishing grass, and large numbers of cattle, horses, and mules always find pasture. The only inequalities of the surface are some sandhills, which rise a few yards above the common level, and some slightly elevated grounds called banks. These banks are hardly pereeptible, but are of great value, as they are not subject to inundation, and eonsequently afford pasturage for the eattle when the lower parts of the plain are covered with water. In the dry season this plain is one immense pasture-ground, until it is again flooded from the Apure and Meta, when the tract on both sides of the lower Apure resembles the Delta of Egypt. The whole plain becomes an immense lake, in which the banks appear like islands. There are tracts then more than 100 miles in length, 20 miles wide, in which the water is from 10 to $12 \mathrm{ft}$. deep, capable of floating large barges.

The most uneven portion of the cattle-plains lies west of the River Orinoco. This country is eovered with low hills, resembling the waves of the ocean when agitated by a gale, being overgrown with coarse grass. The level grassy plains are few, and not of great extent. On the sonthern edge of this uneven part of the plain are several isolated hills, which are surrounded by extensive plains eovered with fine grass; these plains may he considered as the commencement of the immense savannahs which extend southward.

The plains of Venezuela extend over about 26,000 leagues, or 312,000 square miles. This tract, though one immense plain, presents a great variety in elevation, elimatic, and productive powers. Some tracts are hardly elevated above the sea, whilst others rise to nearly $1300 \mathrm{ft}$. Some are arid deserts, while the vegetation of others is extremely vigorous nearly all through the year. The trees on these plains stand singly or form groves of small extent.

The Venezuelans are great meat eaters, literally devouring their own flocks of sheep and herds of cattle. The consumption of meat is immense in the country, being on a level with Australia in that respect. The town of Caracas, with a population of one-tenth of that of Paris, consumes more than onehalf the quantity of beef annually used in the capital of France. The iguana is eaten and considered a great dainty. Twenty-five years ago Venezuela had 9,000,000 eattle, 6,000,000 sheep and 
goats, and nearly 2.000,000 swine. That peculiar animal, the sloth, comes from Venezmela, and so does the ant-eater.

There is at present one refrigerating plant in Venezuela, viz., the Venezuela Meat and Product Syndicate, Ltd., of London. It is situated at Puerto Cabello. The plant has a daily capacity of 2000 head.

l have not been to Venezuela since 1884, so have had to rely on books of reference for part of the above.

\section{BRITISH GUIANA.}

British Guiana oceupies an area, equal in extent to Great Britain, in the north-east of South America. It is bounded on the north by the Atlantic Ocean, on the south and south-west by Brazil, on the east by Dutch Guiana, and on the north-west by Venezuela. It has a seaboard of about 270 miles trending in a south-easterly direction, and a maximum depth of about 500 miles. The colony may be divided broadly into three belts. The northern one consists of a low-lying Hat and swampy belt of marine allurinm, known as the coastal region. This rises gradually from the seaboard, and extends inland for a distance varying from 10 to 40 miles. It is succeeded by a broader and slightly elevated tract of country composed of sandy and clayey, practically sedentary, soils. This belt is chiefly undulating land, and is traversed in places by tracts of sand-dunes rising from 50 to $180 \mathrm{ft}$. above sea-level. The more elevated portion lies to the sonthward of the above mentioned regions. It rises gradually to the south-west, between the river valleys, which are in many parts swampy, and contains three principal mountain ranges, several irregularly distributed smaller ranges, and in the southern and eastern parts many isolated hills and mountains. The eastern portion is almost entirely forest clad, but on the central sonth and south-western side there is an extensive area of flat grass-clad savannah land elevated from $300 \mathrm{ft}$. upwards above sea-level.

The Parliament of British Guiana recently passed a vote of about $£ 12,000$ to be nsed in making a cattle track from the savannahs, in the hinterland, or interior of the colony, to the coast line. The distance is something like 120 miles, and much of it through dense bush.

A Mr. Ogilvie, who is a rancher in the hinterland, is enthusiastic as to the possibilities of cattle raising on the savannahs 
there, and reckons that, given facilities for transporting eattle to the coast, the colony, ere long, could rely on shipping very many head. He states that the savannahs there are capable of supporting very large herds of eattle. There are other warm supporters of the opening up of the hinterland, prominent stockowners who have strong views as to the great possibilities in this direction. At present the only way of disposing of stock is by driving the cattle down to Manaos, and taking what one can get in the market there.

Georgetown, the eapital, when I last visited it, was an ideal tropical town. It is situated on the Demarara River, a stream with a very rapid current.

\section{BOLIVIA.}

Bolivia is the third largest Republic in South America; it has no seaboard, and its goods are shipped to Pacific ports in Chile and Peru. It has an area of 708,295 square miles, and a population of two and a half million. It is bounded on the west by the Andes, and on the east by Brazil. It is mountainous country, but generally becomes flatter towards Brazil. The hills and particularly the valleys grow very rich grasses on the east side, but on the west the soil suffers from low rainfall; however, whenever irrigation is introduced, it grows excellent feed. In the future Bolivia should be a big cattle raising country; diseases are said to be almost extinct, and the climate is an excellent one.

The Republics of Guatamala and Nicaragua have also excellent pastures for eattle raising.

\section{COLOMBIA.}

The Republic of Colombia, 440,000 square miles in extent and with a population of $5,000,000$, oceupies an advantageous geographical and commercial position; its coast is divided by the Isthmus of Panama, facing both upon the Atlantic (Caribbean) and Pacific Oceans, with about 1000 miles of coastline to each ocean. It is generally predicted that, as the Caribbean becomes more of a highway, due to the opening of the Panama Canal, the commercial importance of Colombia will inerease.

Two-fifths of the area of the country are taken up by very broken mountainous territory, the Andes and its outliers, where means of transport are difficult.

The pastoral industries are of great importance in Colombia, and might be very much extended. 
The cattle industry is probably Colombia's most important agrienltural pursuit to-day, and the Republic offers a promising source of supply for the future, as its cheap lands and cheap labour are prominent factors which are vound to stimulate the industry. Until very recently the country exported annually large numbers of eattle to Cuba and Panama, and this foreign trade, together with an increasing local consumption, so reduced the existing stock that all exports of eattle were stopped, and large numbers were imported from Venezuela in order that the country's own needs might be met.

All the northern coastal region is eminently suited for eattle raising, more so than any other part of the country; the low lands are covered with grass all the year round, and the higher lands are also green for most of the year, with the exception of January, February, and March, which are the driest months of the season. The pastures are of Para or Guinea grasses, and the lands used for grazing are said to last for many years with an occasional cleaning, and a burning and a rest during the rainy season.

As to the methods practised in the industry at the present time, it can be stated that practically no care is given to the animals, one man taking care of a very large herd; cows drop their calves in the open; salt is given to the animals infrequently, not more than once a month, and diseases prevail among them to some extent.

The cattle now produced are not large, averaging only 700 or 800 lbs. live weight, but the breed could be much improved by imported blood. It takes five or six years for an animal to reach maturity, the percentage of calves that live is high, and if the dry season is not too long eontinued there is plenty of water to maintain them properly. Good grazing lands ean be obtained from $4 /$ - to $£ .5$ per acre, the price depending on the size of the tract bought, and its nearness to the coast and a navigable river.

The Republic is developing its export trade. Contracts have been made for the supply of at least 40,000 head from that country during the current year. Agents from the United States are much in evidence at the present time. One paeking house at least is said to be considering the feasibility of erecting 
a canning plant, possibly at Barranquilla, which forms a convenient port for such a purpose, and the Government has offered a subsidy of $£ 10,000$ to the first packing house esablished either on the Pacific or Atlantic side, the packing house to have a eapacity of 50,000 head of cattle per year. There are about $2,400,000$ cattle in the country. According to the latest estimate, Colombia should be able to export at least 80,000 head of eattle during the year.

The few small consignments of beef that have come to the English market from the Central American Republic of Colombia have, of course, been a stray supply attracted by the unfailing magnet of high prices. It would seem, however, that there are other calls on this supply than the distant European market, as for some time the supply department of the Panama Canal has been bringing eattle from Colombia to aid in meeting the demand for fresh beef in the commissary stores in the Canal Zone. More than 1000 eattle a month have been slaughtered at Cristobal, Canal Zone, and this will extend, as the meat is said to be cheaper than that brought in cold storage from New York, from which port the supply department is receiving about 100,000 lbs. a month. Freight shortage has made this supply difficult. Meanwhile land has been cleared in the Canal Zone for pasturing imported cattle not in fit condition to be slaughtered for beef; it comprises some 10,000 acres near the Atlantic end of the isthmus, 1500 acres at Empire, 3000 acres at Culebra, and 2300 acres at Corozal, where a Government farm is maintained.

\section{HONDURAS.}

Honduras has an area of 46,250 square miles, and is situated north of the Isthmus of Panama. On the north of it is the Carribean Sea, on the south Nicaragua, and on the west Guatemala and San Salvador. The fifteenth degree of north latitude runs through it. There are about half a million head of eattle in the country.

The Government is endeavouring to encourage stock raising by disseminating information regarding improved methods. Stockmen from the United States are carefully inquiring abont and investigating the cattle resources of the country. Shipments of live cattle are commencing from the port of Ceiba on the North Coast, and a refrigerating plant is about to be installed near Prerto Cortes. Improved stock are being introduced, and an export of 50,000 head annually is looked for in 
the near finture. Most of the cattle at the present time are found in the departments of Choluteca and Olancho, on the southern and south-easiern side of the country. The entire comntry is comprised of mountains and valleys. Honduras, being within the area of the north-east trade winds, has an cquable and agreeable climate, particularly in the higher lands of the interior. The temperature ranges from a minimum of 42 leg. on the highlands to 97 deg. on the coast. Streams of clear pure water abound almost everywhere during the rainy

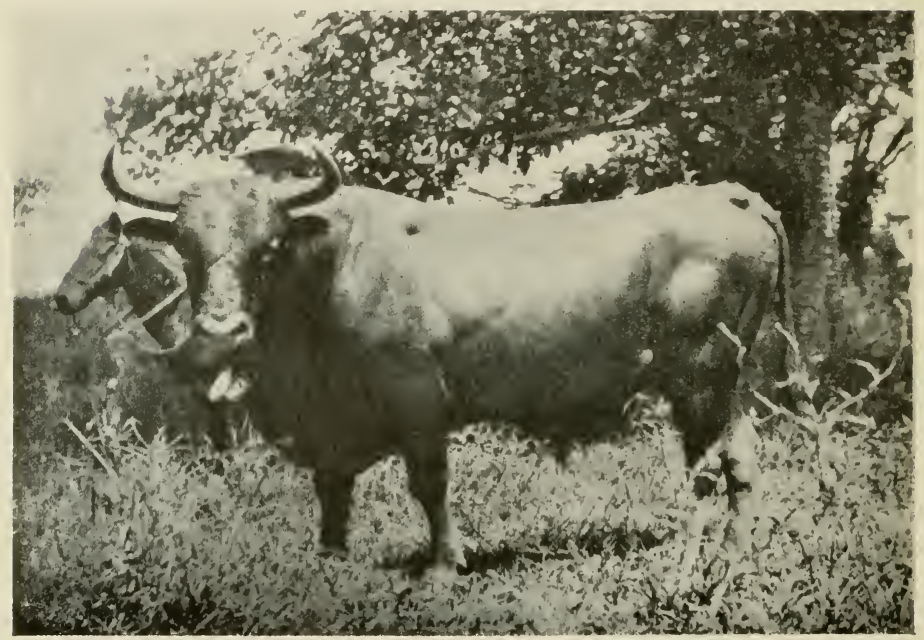

Half-Blood Honduras Shorthorn Buld, Showing Marked Improvemeñ Over Native Trye.

season. During the dry season, the open ranges being much overstocked, the eattle get in a very poor condition, but with good management this can be easily remedied.

In nearly every part of Honduras there is land suited to the raising of live stock in a limited way. There are two departments, however-Olancho and Choluteca-where three-fourths of the cattle of the country are raised. 
Ticks are prevalent, and the introduction of dips and dipping is badly needed. On the coast lands and in the interior well watered valleys, or where irrigation is practicable, permanent fenced pastures are the rule. These are planted with Para. a Guinea grass, which make plentiful and succulent forage.

The average rainfall of the whole country annually is abo:1 48 inches.

The cattle of the country are descended from importations from Spain soon after the conquest. These naturally have much degenerated, the native stock being small; though fleshed and slow to reach maturity, they generally kill at about $400 \mathrm{lbs}$. weight.

So far little has been done to improve them, but the advent of men from the United States, as I said before, is making itself felt. Cuba used to get a lot of cattle from Honduras, but that country is now fully stocked up. The worst disease is the tick: tuberculosis and foot and mouth is unknown. Dips and dipping are badly required, but they must come as modern management is brought in. Honduras has, in addition to an outlet to the Atlantic, an outlet to the Pacific. The best way to improve the stock would be to import good sires, immune to tick fever, from the southern portion of the United States, and to construct dips everywhere. This country as a meat producer should have a future.

\section{ECUADOR.}

The area of the country is 116,000 square miles. Estimated population, $1 \frac{1}{2}$ millions.

Concerted attempts are being made by influential landowners to raise the stock breeding and cattle raising industry to a position of importance, and to enter into the meat export trade. To this end Agricultural Expositions are now held ammally at Quito under the auspices of a number of large plantation owners, with the object of fostering the agricultural industries generally. Some of the high valleys and tablelands of Ecuador are particularly adapted to the raising of stock, and a fine quality of hides and beef is rearly being produced in the Republic in increasing quantities. 


\section{PERT.}

The Republic occupies a long streteh of territory upon the surf beaten Pacific ('oast of Sonth America, extending from near the Equator to latitude nearly 20 deg. south, and thence across the vast mountain range of the Andes to the Amazon Valley. The sea frontage is 1400 miles in length, and the area of the country is variously estimated between 440,000 and 680,000 square miles, portions being in dispute with its neighbors Chile, Ecuador, and Colombia. There have also been boundary questions with Bolivia and Brazil upon its eastern side. It has a population of $4,500,000$.

Cattle and sheep are plentiful, but a lot will have to be done in the way of improving their quality before this country can be taken into account. There is not much prospect for cattle rearing at present, it is more of a mining country, but there are vast areas of rich grazing lands upon which the famous Alpaca flocks are run, and the land is easily irrigated.

Apart from the more spectacular mining industry, it is interesting to note that the plateau and the limestone flanks of the high inland Andes of Peru are grazed by thousands of llamas as well as by seattered flocks of native sheep, for which the short turf that grows from $11,000 \mathrm{ft}$. up to the snow line is admirably adapted. An interesting and suceessful experiment has been carried out by Messrs. Duncan, Fox \& Co., who ten years ago imported 6000 well-bred sheep from the Straits of Magellan to form the nueleus of an Andean sheepbreeding industry on modern lines. The flocks have now increased to over 40,000 under the care of Seoteh shepherds bronght from the Orkneys, the whole undertaking reflecting great eredit on Anglo-Saxon American pastoral enterprise. We have the analogy of Patagonia to prove that wherever the guanaco runs-to which the llama and vicuna are first cousins-it is a sign of good "sheep country," and the logical inference is that 2000 miles of the Andean Cordillera, in Eeuador, Peru, and Bolivia, offer for sheepbreeding a region greater in area even if somewhat inferior in grazing qualities, than that of all Patagonia. 


\section{RHODESIA.}

This vast territory, larger than France, Germany and Holland, is 450,000 square miles in extent, mostly at an altitude of from 3000 to $5000 \mathrm{ft}$. It contains $90,000,000$ acres of good cattle land with excellent natural pasturage, and stock thrive to an exceptional degree in almost every part. No country in the world has better grasses for ensilage-making than Rhodesia. Acres and acres of native grasses can be seen in February and Mareh (towards end of the rainy season) 4 or $5 \mathrm{ft}$. high, which would give four tons of hay per acre if left till April (commencement of dry season), and would make the best of ensilage ere it got too rank. No cost or care of laying the field down in grass or topdressing and locking same np, no fencing or re-grassing at any time. Though the general herds of eattle keep up their condition wonderfully through the dry season (the winter months), though they seldom see anything green, just dry grass with plenty of water, yet the aged cows, the cows with young ealves, and all weakly stock, would benefit by the ensilage, to say nothing of topping off forward store oxen in the time of year when there is keenest demand. With plenty of ensilage on hand, the trek oxen could be worked much longer hours. Cattle are largely on the increase, and diseases of all kinds, which are naturally prevalent where there are big numbers of wild animals, are getting rapidly under control. A great point in favour of Rhodesia is that at present it is not cursed with that bane of many countries, the professional politician, and the longer it can be thus free, the more rapid should be its progress.

A report recently issued by the Directors of Agriculture says that livestock show large increases, in spite of some mortality from quarter-evil and African Coast fever.

Cattle show an increase of 12.83 per cent., the total, $1,083,545$, being owned in almost equal shares by Europeans and the natives. Europeanowned sheep have increased 4.4 per cent.

During the year 1917, 13,221 head of slaughter eattle were sent to the Union of South Africa, and arrangements were made for the extension of this trade to the entire territory in place of a portion of Matabeleland only. The announcement of the intention of the Imperial military authorities to buy cattle in Rhodesia has also given a welcome ontlet. Two thousand head of eattle have been shipped monthly for some time for use of the troops at Dar-es-Salaam in what was German East Africa. Progress has also been made in the preliminaries for the pro- 
posed canning factory, which it is hoped will afford a market for a class of stock not suitable for the fresh meat trade. For the first time in history, a consignment of frozen beef from Rhodesia has been sent to England, and elieited most encouraging reports from Smithfield.

The need of purebred stock to improve the native and grade cattle continues to be one of the most pressing wants, and requirements are still very far from being met in this direction.

The number of dipping tanks is now close upon 1000, and there is every probability of many more being erected in the immediate future. The Compulsory Dipping Ordinance, although its amendment has been freely discussd and is projected, has been widely adopted, till at the close of 1917 it was actually applied to 78 per cent. of the farms in the country, and was in course of adoption over a further 20 per cent.

As an instance of how the introduction of good sires to the native herds of a country improves their condition, a few years ago in Sonthern Rhodesia it was almost impossible to find a native bullock weighing over 550 lbs. dressed weight at five or six years old. Now, however, it is quite common to find three-yearold steers by a good bull, out of native cows, killing at $700 \mathrm{lbs}$. Halfbreds have enormously increased in number, and bulls continue to arrive by every steamer from the home land. Probably there is no country in the world which at present offers such good prospects for the increase and improvement of cattle. It would be a good plan to at once cross the native stock with carefully selected Africander bulls, and get size and hardness into the herds, then cross the improved stock with the progeny of imported pmrebred stock, and be eareful in choosing these sires. A friend who is ranching there now says: "I consider there is no conntry in the world to-day that offers such good prospects for the ranching companies who are prepared to develop the land as Rhodesia. For the small man who can take up 3000 to 10,000 acres, his capital shonld be invested in stock and windmills. Feneing ean always be erected later.

Do not put useless native boys on herding stock; employ the best boy you have on the farm. Teach him his duties, and do not let him keep the cattle in a bunch, as one so often sees. Do not kraal at night if you ean possibly help it. I am afraid that on a great many farms cattle are driven miles to water and good grazing, only to be brought back over the same long tramp at night to be shut up until the following morning. Remember, eattle do not stray naturally, but only in search of food. Tuet 
your calves run with their mothers. Take care that your stock are not roughly handled; remember that beef cattle never want to lose an ounce of flesh from the day they are born.

"Water is a very important question all over Africa, where stock suffer a great deal through want of it. If you have not a rumning stream all the vear round on your farm, erect windmills wherever possible. They will soon repay the outlay.

"If you water your stock from dams or pools, fence them off, and erect a pump and troughs, so that your stock always have clean water to drink. Remember that stock should never have far to go for water; it is wonderful how stock will pull through a bad winter if they have a plentiful supply of water.

"In a country like Rhodesia, subject to a long, dry winter, the use of succulent winter feed for stock is very necessary to keep the animals in condition and maintain growth, especially so in the case of beef steers. Maize silage is one of the cheapest and most valuable forms of stock food. Every farmer and rancher should always have a good supply in hand in ease of a drought or a bad season. Also remember that once the beef trade is established, the most profitable method of disposing of your grain will be to send it to the market on four legs."

Before rinderpest decimated the cattle in 1896 and 1897 innumerable herds browsed on the well-grassed lands of Rhodesia, which also swarmed with game. These eattle were chiefly owned by the natives, who largely estimated their wealth and social status by the head of stock they possessed. Then eame the appalling catastrophe of the rinderpest invasion, followed by East Coast fever, and the land was left desolate. The restocking of the country was largely from the north, and cattle were brought from as far as German East Africa. Angoni cattle, which are a humped breed, were largely introduced. Common native bulls were, of course, used at first; but as the white man began to pay some attention to cattle breeding, Africander, Polled Angus, Shorthorn, Friesland, Devon, Sussex, and Hereford bulls were introdnced with more or less snceess.

Encouraging success has attended the efforts of those interested in sheep raising in Rhodesia. Where the soil and pasture is suitable, the Merino breed is being bred and reared most snccessfully. Exhaustive trials have been conducted, and it can now be confidently asserted that so long as high-class sheep are used, the future of the sheep-raising industry is safe. Sheep are proving more profitable than other classes of stock, largely on account of the excellent prices which can be made for the wool. 
The Liebig Ranch is on the Mazunga, the home station being between thirty and forty miles from the Messina drift on the Limpopo, and some 180 miles from Bulawayo.

There are 28,000 head on the Liebig ranch, and the selected mobs of cows have the service of a fine number of pure-bred bulls, Polled Angus and Sussex, these bulls being kept at their home stations to save them from walking the veld with the herds. The increase is given at 70 per cent., which is regarded as most satisfactory ; and, as the grazing eapacity is placed at twenty acres per beast, the carrying capacity of the ranch is 50,000 . As this number would soon be reached, it is obvions that a large percentage must move off each year

The Mazunga Raneh pins its faith to Polled Angus and Sussex, and makes quicker use of the pure breeds, and more use of Colonial cows to speed up the grade. The eustom is to put an imported bull, when acclimatised, to sixty cows, while an Afrikander will serve thirty; but the imported bull will be fed at the stables, and the food will consist of greenstuff, bran and oil-cake from the Salisbury monkey-nut oil factory, together with one of the "Oxo" by-products.

A system of paddocking is in vogue at Mazunga, which fences off paddocks of 4000 acres to aceommodate 600 head; but the cost of wire has arrested the construction. As one fenced-in paddock is eaten down, the eattle would be moved on to the next, giving the first time to recover.

The pure-bred stock are sprayed and not dipped, and every evening are examined for ticks and rubbed with tick grease if there are signs of the pest.

Nearly, if not all disease, is insect borme, and it is now realised that to preserve the cattle from inroads of disease, dips must be constructed and used frequently. Undoubtedly, the crossbred, or pure, eattle will be more subject to local maladies than are the native female parent stock. But in Argentina, Queensland, and the Southern States of the Union, this difficulty has been largely overeome by careful dipping. Most of the cattle-breeding districts of Southern Rhodesia are at an elevation of from $3000 \mathrm{ft}$. to $4000 \mathrm{ft}$., which gives them an advantage over similar lands in other comntries situated in the same latitude.

Cattle eamuot yet be run in large mobs. Tisually, mobs of 200 to 300 are found to be as large as the herdsman can manage, especially as the herding is done on foot. Horse 
sickness is very prevalent in Rhodesia, and although a prophylactic serum has been discovered for the inoculation of mules, and is successful, the perfected sermm for horses has yet to be produced.

The experienced cattle breeder from Argentina, Australia, or the United States must preserve a very open mind if he is to be successful in Rhodesia. All local methods of cattle breeding are not necessarily wrong in principle, because they appear patriarchal and antique, according to our notions, and the new environment will modify many preconceived ideas. The experience of other lands and ways of working is of inestimable value, and slowly many modifications and changes of present methods ean be introduced. Any too abrupt change is not likely to work for good. The Kaffirs, who have to be employed, as cattle men, understand their own ways of working, and their habits do not lend themselves to sudden changes. The pioneer breeder of improved stock will probably confine himself at first to such elementary changes in native methods as the separation of heifers and young steers from the parent stock, weaning them as late as possible; the age marking of each crop of ealves by ear mark, changing this annually; the separation and final culling and fattening for sale of the aborting cow or heifer ; the early castration of male calves; dipping for the destruction of parasites; letting the eattle run at night where possible, or in the event of this being impossible owing to the shortage of eattle herds, or owing to the presence of too numerous predatory animals, making the night eorrals large, and ehanging them frequently. The conservation of fodder in hay or ensilage must be taken in hand. The curtailing of the periods of bull service must be done with very great judgment, as these native cows are accustomed to run with the bull, and are not accustomed to taking service at prearranged restricted periods. Any abrupt retiring of the bulls for more than a month would, for many years, result in a much diminished erop of calyes at branding time. At first breeders must be content to avoid only the dropping of calves at the commencement of the rainy season. For many years any cow, no matter what her class, which breeds a calf will be retained in the herd until the country be stocked up.

Probably the most interesting and most important development of eattle breeding in Sonthem Rhodesia has been the acquisition of large tracts of land there by the Lemeo and Oxo Company, commonly known as the Liebig's Extract of Meat Company. As a firm of scientific cattle breeders, owning enormous tracts of landed property in Argentina, Uruguay, 
Paraguay, and South-west Africa, with countless herds of cattle, the company has rast stores of successful experience to draw upon, and its presence in Rhodesia is a valuable asset to the country.

"The question is frequently asked," says a recent writer, " "Which is the best country in which a young man with a small capital ean make a start at cattle breeding?" With seme experience of other lands, I think I can safely give a verelict in favour of Southern Rhodesia. Cheap land ean still be obtained to the south of the Zambezi, and if young men will only keep clear of the towns, where the cost of living is ruinously expensive, good use can be made of a small capital. Previous experience in other countries is desirable, but not essential. No man, however, should invest his eapital in land or stock without at least two year's' experience in the country. The native langmagesNatabele and Mashona-should be learned. Under the intelligent direction of the Director of Land Settlement, Government farms have been established to which the aspiring "Estanciero" can go to learn his work. I met some young men who had enlisted in the Rhodesian Police, and there gained much knowledge of the country. Particulars of these appointments and of the farms can be obtained from the British South Africa Company in London. In my judgment, the smallest amount of capital with which a successful start ean be made is $\$ 1500$, and the expenditure of this should be spread over several years. Tery good judgment will have to be exercised if only this small amount of eanital is available. In Rhodesia, as elsewhere, success depends much more on the man himself than on any eash disbursement.'

An "old North Queenslander" writes me:- "It may interest you to hear of Rhodesia from the pastoral point of view. Cattle raising is quite in its infancy here yet. The possibilities are undoubtedly great; so possibly, in the near future, Australians will be attracted to Rhodesia if they wish to extend their operations to other comntries. The Company I represent is the Rhodesian Cattle and Land Company Limited (registered in England). We have acquired in Northern Rhodesia 100,000 acres of freehold land in one block on the south bank of the Kafue River, about 100 miles up from the railway bridge. This railway is the main line from Cape to Cairo. This Northern Rhodesia ranch (Lochinvar) is only lightly stocked yet, the first mob arriving here in April, 1911. We have 4000 head now, but the ranch is capable of carrying 20,000 head. This year's 
ealves number 400 , and we expect to brand well over 1000 next year. We are breeding from Hereford bulls imported from England and native cows, mostly Barotse.

"The first grade is a better result than I expected, and I hope that in a very few years the herd will be one to be proud of. The country is partieularly good. This you may judge from my estimate of the earrying eapacity of the ranch, 20,000 head of eattle on 100,000 acres. There is a large area of this ranch which is inundated each year by the overflow from the Kafue River, and it remains flooded for two or three months. After the flood waters have gone, the grazing on this area is wonderfully good, the grass remaining very green until the following rainy season. The grass that grows on these flats is partienlarly sweet, almost as sweet as sugar-eane, and eattle, pigs, horses, and mules all relish it thoroughly and keep fat all the time they are grazing on it. During the wet season, when this part is unavailable, we have all the stock on the high sand ridges, where Guinea grass grows Iuxuriantly and the stock do splendidly We have a fair amount of both elasses of eountry abont equally divided in this one block of land.

"Owing to the presence of large herds of game, it is impossible to fence in large areas, the game being so destructive. Lions chase the game about at night, and a herd of several hundreds of zebra or large buck will charge into the fences. No fence can stop them. Under the cireumstances, we are compelled to herd the cattle by day; at night, ther are yarded into barbed-wire yards. This necessitates a rather bigger staff than that on an Australian station. The herdsmen are natives, three or four to each mob of 500 or 600 head of eattle. It would amuse an Anstralian pastoralist to see a mob of 600 cattle handled by three men on foot. From this you will see that the eattle are particularly quiet.

"The market for Northern Rhodesia is the Congo, where it is fully expected very big developments will take place in the near future. There are enormous copper deposits in that territory. At present, Congo buyers pay 35/- to $40 /$ - ner $100 \mathrm{lbs}$. dead weight for slaughter stock, the buyer paying railage. The cattle are taken away by rail alive, and the dead weight is estimated before they leave Rhodesia. This price is likely to be maintained (if not improved upon) for some years to come. The presence of tsetse fly in the Congo prevents stock from being bred there in a big way. 
"Liebig's Company has lately secured a large area of land in South Rhodesia, and I hear on very good authority that that company purpose erecting a big factory there within two or three years. I understand that this company is particularly pleased with the land it has secured and with the appearance of the stock.

" My company has also a ranch of 150,000 acres of freehold land in South Rhodesia. This has only lately been purchased, and not much has yet been done there in the way of stocking it.

"I am very disappointed that up to the present I have not been permitted to import Hereford bulls from Australia. The Rhodesian Government have not yet decided to permit this, the matter being still under consideration. My contention is that, as the climate of Rhodesia is almost identically the same as Queensland, stock from Queensland (or any part of Australia) would require less acclimatising than stock from England. I also contend that equally as good blood conld be introduced from Australia, and at a lesser cost. Stock in Australia are not so 'forced,' and are, therefore, more hardy and more suitable for the veldt in this country.

"From an agricultural point of view, the possibilities here are also good. I have known from fifteen to twenty bags of mealies to be the return per acre from various farms on the Kafue: ten bags, however, is more general-200 lbs. to the bag. Many parts of the Kafue should grow excellent sugar-cane, the soil being particularly rich. Thousands of acres could be irrigated by lifting water from Kafue River $15 \mathrm{ft}$, and fed from one main furrow. Thousands of acres could be ploughed without any expense in the way of clearing. Not a stump, or a tree, or a stone to be moved. Many parts closely resemble the hest lands on the lower Burdekin country in North Queensland, where sugar-cane grows so wonderfully well."

Mr. Richard Walsh, the British South Africa Company's expert in ranching, gave some interesting information when interviewed in London recently. Mr. Walsh selected the big areas, between 3 and 4 million acres, in Rhodesia, which the company is now devoting to eattle ranching. The million-acre ranch known as Rhodesdale, is now in a fairly advanced condition, is partly in Mashonaland and partly in Matabeleland, and the railway runs throngh it. A bigger scheme, but one much less advanced, is represented in the Nuenetsi territory of three million acres, lying to the south of Victoria. There is also a ranch of 100.000 arres about 60 miles south of Victoria. 
Mr. Walsh said:-

"During the past two years, we have got together 35,000 cattle, of which 22,000 are on the Rhodesdale ranch, and the balance on the other two. So far, we are simply building up the herds, and we are only disposing of the old cattle. Beyond that, we expect to put practically nothing on the market for three years. At present, we are going on the theory of twenty acres per animal. That is the proportion we are thinking of before starting to export.

\section{Building up the Herds.}

"The foundation of the herds is native cattle, with the exception of 2500 better bred colonial cows from the Cape. At present we are using a number of Afrikander bulls, in addition to some Shorthorns, Herefords, Polled Angus, and North Devons. These I consider as the breeds that will probably do best in Rhodesia. I have every confidence in the country as a great cattle country. It is notorious that the herds of Lobengula's days were a good deal better than the present-day cattle in Rhodesia, more particularly in size. They had been bred with some care, and it is evident that Lobengula and his head-men had the instinct of stock breeders. They also had, from long experience, an expert knowledge of the best grazing localities.

"Mainly the rinderpest and other diseases threw the eattle back; but we need not fear that sort of thing now, as we have a very efficient veterinary department, and cattle are rendered immune by inoculation. From my experience in other countries, I consider Rhodesia a very healthy cattle country. It certainly has no more disease than any other country, and with our veterinary department and the practice of general dipping, all these will be eradieated.

"The grasses in Rhodesia have better fattening properties than in any other ranching country I know. Very little extra feeding is necessary in the dry months-just enough to help one to take care of the weak cattle. I know of no other country in which eattle carry their condition as they do in Rhodesia through what may be regarded as the 'bad months' from the stockfarmers' standpoint.

\section{Coming Beef Exports.}

"Our aim for the next few years is to produce a better type of beef animal in much larger numbers before establishing our export trade. While we are building up our herds in this way, 
there will be a growing surplus of eattle not required for the purpose. The great present want of Rhodesia is a camning factory, and I am glad to say there is every prospect of one being established at once. That will enable us to deal with meat other than the big export which we are arranging for later-when the meat will be sent to Europe either chilled or frozen. Apart from what the chartered company is doing, several big ranching companies have been started, or are being started, in Rhodesia. As their aim also is the exjortation of meat, the country should take a big place in the meat market at an opportune time."

There are 3,961,600 acres in the Hartley District of valuable grazing land. In that 6000 odd square miles, the variety of soils is such as to ensure every possible requirement for eattle raising or for ranching. Heavy black humus-filled land or rich red loams alternate frequently with stretches of sand veld. If there be those disposed to despise the granite soil, let it he known that among the biggest ranchers there are men who will have. no. sort of a farm that does not include a proportion of this sand veld in its grazing.

There are eight large rivers and their tributaries meandering through this territory, and when it is mentioned that lime is prevalent along these streams, it can be well understood that Hartley cattle have most of the conditions favourable for heavy frame forming.

Before the rinderpest swept across Africa and well-nigh exterminated the game, Hartley was one of the most heavily stocked grazing grounds of the country. Rhodesia then was like a game reserve in the extent of the herds of bovines it fostered. The remnants of the big buck of these herds had begun to re-establish their depleted numbers at the time the suspicion began to fall upon the larger game as earriers of the tsetse fly. Consequently, since a known "fly" area eame to be defined, and was thrown open for promisenous shooting of even Royal game, the kudu, sable, eland, waterbuck and others of the antelopes, with the elephant, rhino and hippopotamus have been harried almost to extinction once more, and the parallel shrinking of that tsetse belt is well recognised. It is probable that that area is responsible-though it is a fraction of the total extent of the district-for a widespread belief that Hartley is unhealthy for stock. There is one large ranch in the midst of the "fly" belt; and one farmer at least, who claimed an abatement of the purchase price of his farm because he learned that 
his land was within the confines of the suspicious ground, has now discarded his donkeys and has taken pretty extensively to cattle. The B.S.A. Co. have seleeted a ranch of approximately a million acres which lies largely in Hartley, and it is being rapidly stocked with valuable eattle; and, furthermore, Hartley 's livestock figures stand first for Mashonaland in numbers, and only Gweto in Matabeleland surpasses it for the whole of the Rhodesia districts.

The last stock census showed 33,002 cattle in the district. This is at the rate of 120 acres per head, so it will be seen that there is vast room for extension. Though at present there are more farms returning statisties than in any other distriet, there is much land still for sale. Though some of the best of the pedigree bulls that have been imported have come from Hartley farms, the great bulk of herds, so far, like those of all Rhodesia. are not far removed from the native stock, having very largely, originally, been purchased or traded from the kaffir res'rvos around. That source of origin accounts for the hardiness in herds that earned the district its true reputation for cattle health.

Hartley, with much of Africa, has been suffering keenly during the past few years from uncertain rainfail, and a depression of a like period in eattle prices has struck it hard as well.

During these lean years, the stoek has been multiplying in a steady increase, though their cash value as individuals sank at times far below their purchase price. Under that steady fall, there has been little inducement even to disperse a herd that gave little promise of interest on its capital value, for "a pound a leg" has been a very common bid at auctions. A holding-on policy has, therefore, been the rule, and now the reward seems in sight, and the larger profits will now be the more easily secured beeause of the hard experience gained in earrying on through the seasons of narrow margins. The almost vanishing prices being paid for grain, as ngainst the steadfast price of butcher-meat has done much to press home the desirability of selling crops on the hoof. Outbreaks of East Coast fever occurring urged the compulsory dipping that is now in vogue, and that compulsory elause enforced the building of the requisite tanks. Seeing the night herding, especially of working oxen, that other districts have to resort to, impressed the excellence of the 
Hartley pasturing, that renders that expedient unnecessary, but the benefits of the free night grazing are so well recognised that wherever possible fenced paddocks have ousted the primitive kraaling methods. The number of miles of fencing will immediately be immensely extended so soon as wire is again reasonably procurable.

Sonthern Rhodesia offers the farmer three varieties of climate and country, says a recent writer:-

"(a) The high grazing veld of Matabeleland, with an altitude of 4000 feet; $(b)$ the higher altitude of northern and middle Mashonaland, with a greater rainfall and favoured conditions for the culture of mealies, tobaceo and oranges; and $(c)$ the low-lying country skirting the Limpopo, which is also suited to cattle. There are ranches in Mashonaland on the granite lands which are too poor for mealies, but the cattle are found chiefly on the Matabele side where the grass is shorter, and, it is said, sweeter. The Zulus, like most natives, were good judges of cattle country, and when Moselikatze went north, he picked his site on land where now are most of the white cattlemen, and his herds grazed west to where the big Rhodesdale Ranch is situated, and south to where the other big ranch, owned by Liebig's, is located between the Limpopo and the Matoppos.

\section{LARge Requireants.}

"Formerly, business men in Bulawayo talked 'gold'; now they talk 'beef'; and in the clubs most heated arguments rage between the Hereford men and the Polled Angus followers, while Shorthorn, North Devon and Sussex admirers have a say. As a matter of fact, no breed has yet been proved, and the ranchmen are at present finding out not what breed is best for the whole country, but what breed or breeds do best under the varying conditions in various districts. The B.S.A. ranchmen have. for example, satisfied themselves that Shorthorns do better on the southern ranch below Victoria than they do at Rhodesdale, while Liebig's are inclined to think that the Polled Angus and Sussex are the best choice. They are trying out the breeds, and as they swap experiences, they will in time select their fancies and stick to them; but it seems clear that the recognised beef strain will differ in one district from the other, which means that most breeders of pure-bred bulls may expect a market in Rhodesia. Last year, over a thousand head of heifers and bulls were imported, chiefly from the Union, and each year the big ranches are on the lookout for bulls. In September last, Mr. Fleming (Manager of the Rhodesdale Ranch) was in Bulawayo district 
looking for 150 young bulls, and he purchased fifty from one breeder. As he told me, he was pleased to find that the small breeder had become alive to the necessities of the big ranches, and had been concentrating on the breeding of pure-bred beef strain with excellent results.

"In time, the big ranches will create their own buil-breeding herds, but this will not be for another five years or so, and even then the smaller ranchmen will be in the market for sires. They rum, on the average, one bull to thirty cows, and as a small ranch would carry 7000 cows, each such ranch would require 230 bulls.

"The Chartered Company's two ranches at Rhodesdale and Victoria cover together about 70,000 head; Liebig's carries 28,000 head; and the ranches run by De Beers, the Anglo-French, and the Central Estates, are coming on. In addition to these, there are numerous small ranches, which earry from 300 head up to 7000 , and are rapidly growing. All these ranches are breeding beef, and to breed beef they must have pure-bred bulls of the beef strain, together with heifers, and this demand creates, as I have said, a market worth studying. It may be noted that they have nothing to do with Friesland, Jersey, Ayrshire, and other dairy breeds; and it may also be mentioned, to avoid trouble, that many of the cattlemen in Rhodesia know more abont the beef breeds than most breeders in South Africa, and that they will not take inferior animals."

\section{Experts From America.}

Naturally, a big ranch costs money in the creation. The Chartered Company last year spent some $£ 20,000$ on native cattle, representing a fraction of the outlay, and Liebig's have probably spent well over $£ 100,000$ in live-stock. Expert knowledge is required to protect such large interests, and the B.S.A. Company secured the services of two experienced cattlemen from the United States, in the persons of Mr. R. Walsh and Mr. H. Fleming. Be it understood these are not cowboys, but gentlemen of education, who have made it their business in life to study eattle and their management, beef production, and the marketing thereof. Mr. Walsh directed a big ranch in America, and Mr. Fleming had twenty-one years' experience learning the business, as he puts it, "all sides up." It has been asked in Rhodesia, why Sonth Africans were not engaged, and the answer is that 
ranching was not known in that comntry, and that the huge undertaking necessary would have seemed beyond the range of men aceustomed to handle cattle in small numbers. The United States is the biggest cattle country in the world, and its ranchmen have "thought in thousands," and handled the conditions which threaten to overwhelm the manager who is not nsed to eattle by tens of thousands. There is a boldness in the design of a large ranch that must rather dismay the eautious man, and Mr. Fleming relates that when he went on the market once to buy 150 bulls at one swoop the eyes of an old-timer nearly popped ont as he eried: "One hundred and fifty! My word, I thonght I was going strong when I bought three at a go!", South African breeders know eattle fore and aft, top and bottom, but they did not have the experience of ranchmen, and aceordingly the Chartered Company sent to the Tnited States for two eattlemen of proved knowledge, capacity and taet. The two stepped into their places mietly, earved ont one million acres from the unocenpied land, divided this enormons area into seven blocks, and set abont building up a beef strain, on the bedrock of the small but hardy native strck: and they have gone their way unobtrusively, working out their ideas withont foreing their opinions on others. Liebig's Ranch followed the same large lines of development, but not the same policy of breeding.

It will be seen by the foregoing that the possibilities of Rhodesia as a beef producing country are enormous, and fair supplies of excellent beef can be looked for in the immediate future. To the west there is another very excellent fertile country in Bechuanaland, containing 225,000 square miles of ideal cattle comntry. However, the eattle at present are of the native type, and very little has been done in improvements so far; but now the war is over, there is little doubt that in time that country will be exploited and its herds improved.

The Rhodesia Meat Packing Company Limited has heen formed, with a capital of $\$ 100,000$, to acquire a piece of land sitnated at Odzi Station, Mashonaland, with water rights on the Odzi River, for the purpose of erecting meat-canning and freezing works. The eapacity of the factory is to be approximately 75 beasts per day. It is the intention of the eompany, as soon as the canning works are in operation, to proceed with arrangements with a view to the freczing and export of meat for shipment overseas. 


\section{The Cattle Indestry.}

Essentially, Rhodesia is a stock country. The conditions point strongly to meat as the principal ultimate product to be elaborated off the veld. Dairying, too, undoubtedly has a bright future, yet primarily beef is to be looked to as Rhodesia's staple export to the world's markets; milk, butter, and cheese will chiefly meet the local demand.

Cattle-raising requires more capital and a longer time before profits accrue, but ultimately yields a higher return. Cropgrowing yields a more regular and an earlier return-a more vital consideration to the newcomer and the man of limited means. Ranching, or at least cattle farming on extensive lines, is a growing feature of the times in Rhodesia, so far with a very promising measure of snceess, the one general want as yet being numbers. The indigenons native cattle supply the foundation stock, improvement being gradually effected by the introduction of bulls of European breeds. The Government is endeavouring to encourage the systematic improvement of cattle in the country, and steps for the establishment of a stud farm have been taken, whilst no inconsiderable time is devoted to tendering information and advice on the subject.

There is no doubt that Rhodesian methods in eattle farming are advancing, the most noticeable signs being increased attention to such matters as hay-making for winter use, production of forage and of root crops for stall feeding, the construction of dairies and dipping tanks, better housing, more attention to the care of ealves, and, perhaps above all, fencing. Changes in the direction indieated are conspicuous on some of the large ranches in Lomagundi and the farming districts of Goromonzi, Umtali, and elsewhere, where eattle now run day and night in camps, undisturbed and free, with very obvious advantages, as against the primitive eustom of herding all day and kraaling at night. The mortality of cattle from casual ailments and accidents is singularly low throughout the country, but particularly so where fencing enables the nightly concentration in kraals to be avoided -an effective protection against the appearance and spread of contagious disease-and where the conditions of life are otherwise rendered wholesome, natural, and easy. 


\section{SOLTH AFRICA.}

The Union of South Africa, comprising Natal, Transvaal, Orange State, and Cape Colony, continues rapidly to grow in importance as a source of Empire meat supply. The pastoral condition of the comntry is eminently suitable for beef production on a large scale, and the existing herds of eattle, which in many parts are being rapidly improved, already total $8,000,000$ head. Everywhere one sees efforts to improve the quality of the beef and to make it suitable for the export trade. Freezing works are being erected and enlarged at the various ports, and railways are being extended. There is an ever-increasing demand for stnd eattle of both milk and beef breeds, and African buyers at times almost equal those from the big South American Republic in the prices they offer the British breeders. Even during the war, continual consignments are being received. Under an arrangement entered into some years ago, between the Union Gevernment of South Africa and the Union Castle Mail Steamship Company, it is provided that the shipping company shall carry pedigree cattle freight free for a stipulated number of vears. No charge is made for freight, but a charge is made for fodder and attendance of $£ 4 / 15 /$ - per head, and a very active demand, and an increasing one, is being made for all descriptions of high-class animals. Some years ago, Mr. Armour, of Chicago, stated that, in his opinion, South Africa was the grandest ranching country in the world; it only needed brains, industry and enterprise. Cattle since 1904 have increased from $3,500,000$ to, in $1917,8,000,000$ head.

Without doubt, South Africa is destined to be a beef-exporting country on a large seale before many years are over. At present, the quality, all round, needs standardising. and the butchering and dressing requires improving; but this is undoubtedly being seen to by those who wish to see the industry firmly and profitably established; they are details.

The meat is now a more or less regular feature on Smithfield market, and it is gradually becoming more regular in quality as the producers become better acquainted with the market needs.

A very fine sample of South African beef was to be seen recently in the Smithfield market. This was a consignment of 16 beasts, averaging $880 \mathrm{lbs}$. per body. The quarters made a very fine show; they were prize meat from the Johannesburg Fat Stock Show, having been sent by the South African Meat Export Company after exhibition in Johannesburg. The meat 
was from Aberdeen-Angus cattle, with a strain of Devon. Its condition was perfect, good butchering being another quality, which it was welcome to see. The meat fetched $8 \frac{3}{4} d$. by the side, and attracted a good number of visitors from outside the market, including sir Owen Philipps, K.C.M.G., the well-known Royal Mail Steam Packet chairman, who has done so much to further South A.frican trade.

Farmers in all parts of South Africa are awakening to the potentialities of the meat export industry, and various concerns are being formulated to take up the business. The pioneer concern, known as the Farmers' Co-operative Meat Industries Limited, has increased its eapital considerably to enter upon a larger enterprise, and another large company, comprising some of the best-known names in South Africa, has been formed.

The generous offer of Sir Owen Philipps, to carry pedigree stock from Britain to South Africa frec of charge when he took over the Union Castle line and obtained the renewal of the South African mail contract, is undoubtedly having beneficial effects throughout the Union. Instead of being bred for "trekking" purposes only, as in the past, bullocks are now bred for meat, and there is great improvement not only in the quality, but in the dressing, of the frozen article sent to the English markets.

Sir Thomas Robinson, the Agent-General for Queensland, on behalf of the British Board of Trade, has been purchasing South African meat as well as Australian, New Zealand, Argentine, Brazilian, and Canadian, but the quantities since the beginning of 1917 are not known, neither is the destination of the meat. Over and above the purchases on behalf of the Government for Great Britain and the Allies, there have been some small shipments, sometimes 500 or 600 quarters, direct to London by the Union Castle boats. The meat has fetched an average of $9 \mathrm{~d}$. to 11d. per lb. for hindquarters, fores selling in the usual corresponding ratio. In 1916, the export of frozen meat from South Africa amounted to $17,687,121$ lbs., valued at $£ 354,341$. All this was beef; there is no mutton going forward. Of the above quantity, $4,297,313$ lbs., valued at $£ 75,399$, went to the United Kingdom markets; the remainder was for Government contracts. These figures show a great advance over those of 1915 , when the total export of meat from South Africa amounted to $6,056,435$ lbs. valued at $£ 107,362$. England took 5,095,000 lbs., of the value of $£ 86,000$. Complete figures for 1917 are not available, but the total export of beef up to 30 th June amounted to 91,263 quarters, this quantity including the Government contracts. The 


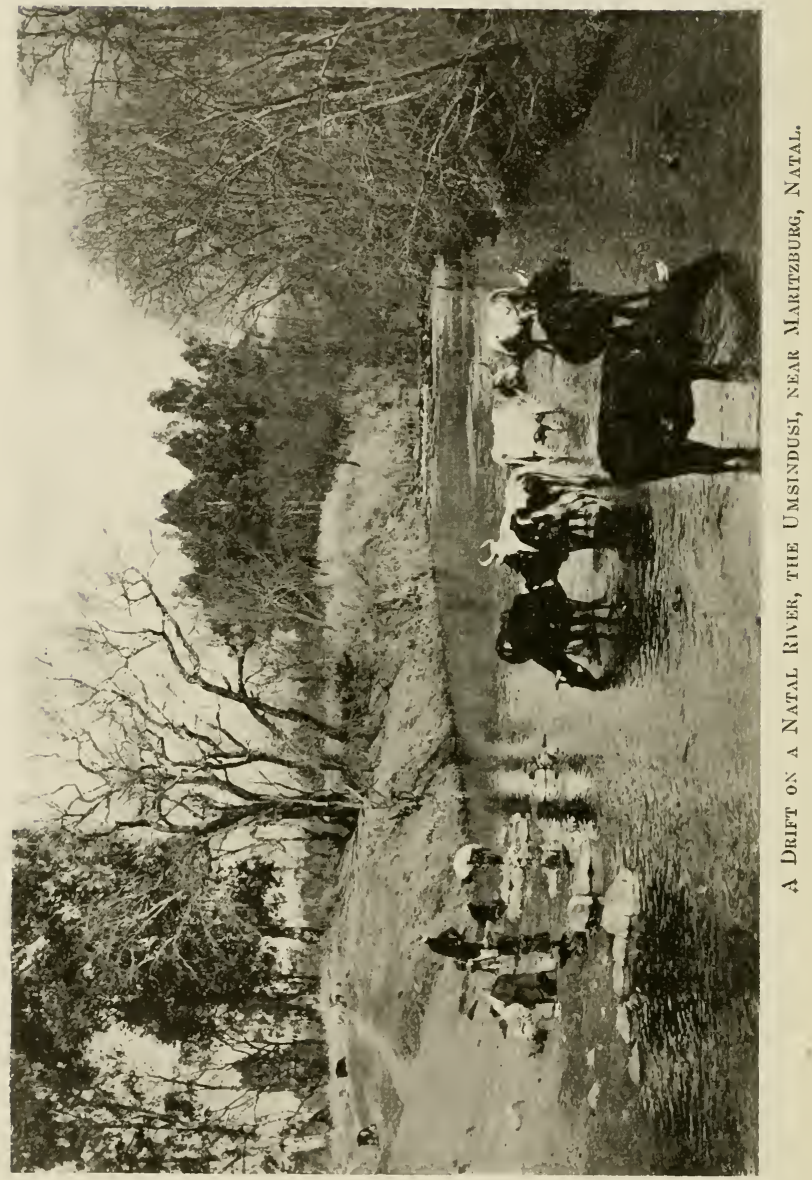


second half of the year is always the busiest shipping season. The South African farmers are making big strides, and are doing all they possibly can to put the industry on a firm basis. Certainly, an industry which is already bringing in over $£ 300,000$ a year is one which is bound to receive encouragement. There is so much refrigerated produce now sent away from Sonth Africa that the cold storage facilities at the ports are quite inadequate. The stores are often full up, owing to the shortage of tonnage.

Everything points to the beef export trade of South Africa being a huge thing within a few years. For the past two or three years, farmers have been repeatedly urged by the Government experts and other anthorities to improve their cattle, and to direct proper attention to the question of feeding. This advice has not fallen on deaf ears, for there is already a very noticeable improvement in both directions. Again, farmers now comprehend the wisdom of the dipping practice, and losses to-day are almost negligible as compared with those of a few years back. The potentialities of the Union in this direction have impressed many, and adequate preparations are being made to deal with the future herds of the farmer. Four hnge cold storage works and abattoirs are being erected at Durban, and the Government is extending the Congella wharf by about two miles. Similar works are being erected at Port Elizabeth, Lorenzo-Marques, and several inland centres. The eapacity of each of the coastal works will be such that will enable the companies to export throughout the year, the idea being to purchase almost entirely during the summer and autumn months.

The following description of a South African cattle property, by the principal of the School of Agriculture, Cedara, will be of interest:-

"This property, comprising some 100,000 acres of dry sand country, is near Mafeking, and the herd is a monument to the adaptability of the Shorthorn, and also of his prepotency and impressiveness as a sire. That other of the improved breeds might have done equally well is not denied; but in this ease, the Shorthorn was the improved type used. It is proposed to give details in regard to this successful herd, and to show what is so apparent, viz., that the continual use of highlybred bulls of sound constitution and excellent stamp has increased the valne per head of the cattle considerably, whilst turning out an annual surplus of animals of the butcher type, 
full grown and fat at three to four years old, which, when killed, give meaty carcases fully calculated to meet the demands of the European market.

"Eleven years ago, a commencement was made by Mr. L. S. Meintjes with a small Shorthorn herd. Three years afterwards, in conjunction with the African Farms Ltd., 500 breeding heifers and cows were obtained, chiefly in the Cape Province, and with the exception of some Friesland-Jersey crosses, a few North Devons, and some nondescript animals from South-West Africa, all the original eattle showed Shorthorn blood.

"In 1907, the company started importing bulls, when two Lincoln Reds were obtained, their breeding showing some Coates Shorthorn blood. Since then only good, well-bred Coates Short-

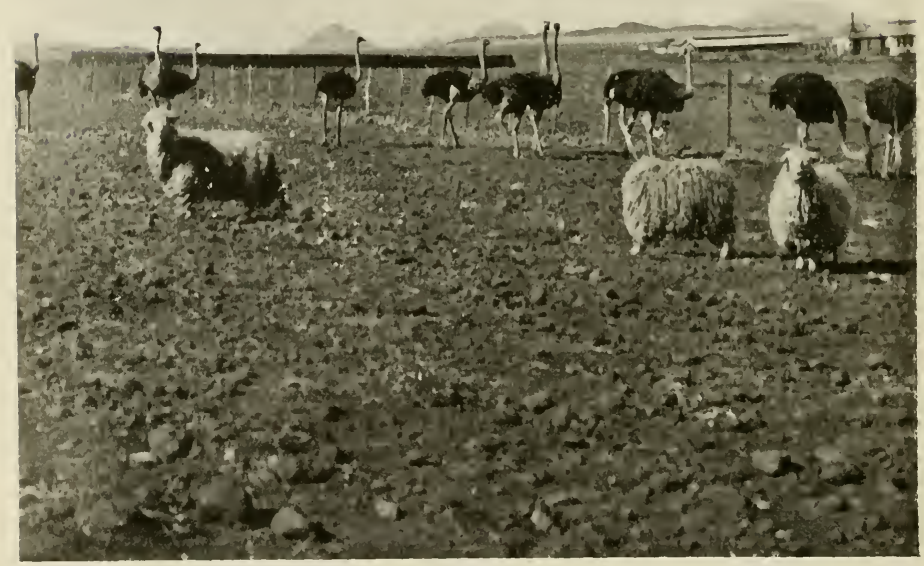

Typical Karroo Scene.-ANgora Goats and Ostriches, Grootfontei:, Cape Colony. 
horns of the "Scoteh" beef type have been used, and all these bulls trace back directly or indirectly to the herd of Mr. W. Duthie, of Collynie, and thence to the Cruickshank herd.

"Females have from time to time been imported. The first batch of Lincoln Red females do not appear to have done well. They did not maintain themselves in good condition. Nineteen pure-bred Coates Shorthorn cows have also been imported for the purpose of breeding bulls for use on the ranch, and for sale. Such home-bred pure-bred bulls find a ready market. The imported cattle, after becoming acclimatised, do just as well on the veld as the grade cattle reared on the estate. Age for age, the females bred on the ranch are equal in size to the imported animals. The bulls are smaller, however, as no attempt is made to force their maturity.

"Taking the original mixed herd, each generation shows some improvement over the original, but now and then a throw-back appears, and they will appear for a number of years. Contrary to expectation, the higher graded animals from the original cows, with strong Shorthorn foundation, of which there are now four generations represented on the ranch, do not show any tendency to lack of vigour and hardiness, being quite as robust, if not more so, than the original eattle. This robnstness of constitution, with the consequent ability to make the utmost use of the veld, has been secured by a fairly strict selection of breeding females and a very strict adherence to substance, strength, and vigour of constitution in the sires used.

"In addition, taking seasons into consideration, the sncceeding generations show progressively greater tendency to early maturity, thus demonstrating that the finer bred eattle can make as good or better use of the veld than their presumably more hardy forbears. The same also holds for the lower grades, from the very mixed Jersey-Friesland and Africander foundations. This finding encourages the owner of the ranch in his idea of persisting with Coates Shorthorn bulls of the right stamp. The paramount idea has been to produce an ox matured at three to four years, and dressing up to $800 \mathrm{lbs}$., from the veld alone.

"At present on the ranch there are some 2500 head of cattle. which numbers are being gradually angmented. Of this number, 1000 head are breeding eows and heifers. For this number of females there are kept eighteen bulls. 


\section{Breeding and Management.}

"The cows are offered service at any time during the year, there being no fixed service period. Thus, calves are dropped every month. The method of service is to take the stabled bulls down to the various watering places and to await the arrival of the eows from the veld. In this way there may be served, say, four or more cows in a morning, and in the afternoon, different bulls are taken down. It has been found inadvisable to allow a bull more than three cows in any one day. Thus, the dry herd, at the height of the season, will require the services of as many as six different bulls in the one day. In the far distant camps there are erected bull sub-stations, so that the bulls may be kept at their stations without the long trek back to headquarters, being fed and cared for near one of the watering installations.

"ITeifers are mated usually about twenty months to two years old, according to size, it having been found that to allow them to go any longer engenders barrenness, owing to their being too fat to settle to the bull. Taking the average, the percentage of calves per annum, or the breeding efficiency of the herd, is in the neighbourhood of 60 to 65 per centum. As stated above, ealves are dropped every month. It has been observed that those calves born in the dry winter months are slower in maturing. It is a matter for consideration whether the additional expense for bulls and the risk incurred in having a definite breeding season would be entirely counterbalanced by the admittedly greater uniformity of the young stock which would ensue. Calves are weaned usnally at ten months, or younger. Bull calves are castrated at from three to ten days old. Weaners are run well towards the ontskirts of the ranch, and after a year those heifers of satisfactory size are returned to one of the breeding herds. Oxen are drafted on to good rearing veld at nine months, well away from the centre of the ranch, where they grow out, and, when about three years of age, drafts of oxen are taken on to the best veld and given some months in which to finish.

"The oxen reared on the ranch are large, of a desirable beef type, though somewhat long in the leg, and, perhaps, rather coarse in the front; they are weighty and otherwise of good conformation, and dress out well at slaughter.

"The following particulars of oxen from the ranch at four vears, exhibited at the agrieultural show at Johamesburg on the 6th to 9th April, 1915, and slaughtered at the municinal 
abattoirs, may be of interest. It may be mentioned that these oxen were retained at the ranch as not being good enough to go forward with the consigmments about four months earlier, and consequently they are a little older than the average:-

\begin{tabular}{|c|c|c|c|c|c|c|c|c|}
\hline \multirow{2}{*}{$\begin{array}{c}\text { Catalogue } \\
\text { Number. } \\
649\end{array}$} & \multicolumn{3}{|c|}{$\begin{array}{l}\text { Live Weight } \\
\text { Shrunk. } \\
\text { lbs. }\end{array}$} & $\begin{array}{l}\text { Carcase } \\
\text { Weight. } \\
\text { lbs. }\end{array}$ & & $\begin{array}{r}\text { Estima } \\
\text { Frozen V } \\
\text { lbs. }\end{array}$ & ght. & $\begin{array}{c}\text { Dressing } \\
\text { Untrim'd. } \\
\%\end{array}$ \\
\hline & $\cdots$ & 1165 & . . & 695 & & 660 & $\cdots$ & 59.0 \\
\hline $6+8$ & . & 1126 & $\ldots$ & 683 & & 649 & * & 60.6 \\
\hline 656 & . & 1208 & . & 727 & $\ldots$ & 690 & • & 60.0 \\
\hline 647 & . & 1176 & ${ }^{\circ}$ & 694 & . & 659 & $\ldots$ & 58.0 \\
\hline 654 & . & 1210 & $\ldots$ & 725 & $\ldots$ & 688 & $\ldots$ & 60.0 \\
\hline
\end{tabular}

"Description of No. 649.-Shorthorn, steer, four years. Condition good to choice, smooth, loin fairly well covered, ribs require to flesh down further.

"Type.-Beef, good width and depth, little paunch, inclined to be leggy, not coarse. Hindquarters excellent. Shape, a little lacking in flesh, quarter good, twist and flank fairly full. Skin handles well.

"Carcase.-Covering smooth, half-inch of fat over loin, slightly hollow in loin, and lacking a little over the shonlder and ribs. Slight marbling, fine quality, lean bright. Fat, light yellow.

"The description of the others would be in many respects similar to the foregoing."

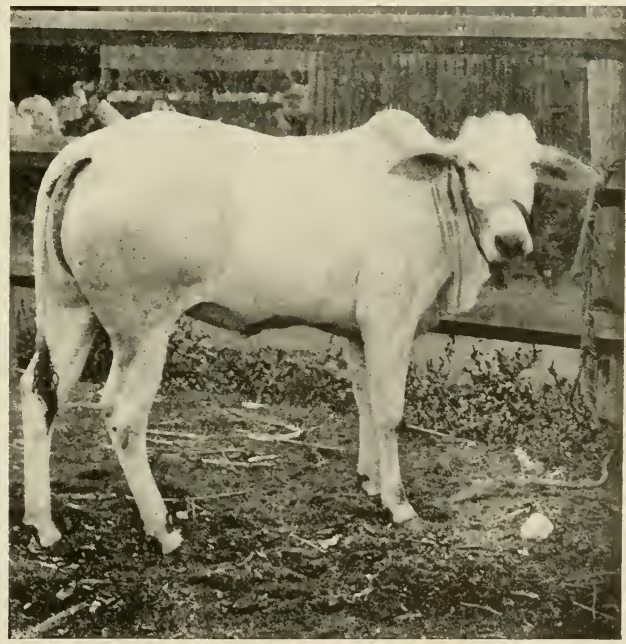

Zf bu Heifer from Soethery Indi. Nellore Variety. 


\section{MADAGASCAR.}

The French Island of Madagasear lies off the coast of East Africa, and runs 1000 miles north and south, with a breadth up to 360 miles. It is 226,000 square miles in extent, and is mostly mountainous country, from 3000 to 5000 feet high, with healthy, well-grassed undulating valleys and low hills. Madagasear has large herds of eattle, and is an ideal country for cattle raising. The herds number fully seven millions at present, and beef is already being exported. In a few years, France could, by the importation of stud bulls, enormously inerease not only the numbers, but the weight of the present stock, and, without trouble, fill the gaps in their own meat supply by beef from this beautiful island of theirs. Any visitors to Madagascar must be impressed with the richness of the grasses, not only in the numerous valleys, but on the hills. Burnt year after year by big fires, it springs up again with a profusion much more than sufficient for the present stock running on it.

In fact, the pasture land of Madagasear is almost unrivalled in any part of the world. A committee which was appointed recently by the French Government to investigate in what manner the native cattle would be able to contribute towards the meat supplies of France, has sent in its report. The following conclusions were arrived at:-

"(1) The introduction of live stock from Madagascar into France can be realised very soon, and all that is needed is transportation facilities; (2) if the cold store works actually existing in Madagascar can increase their eapacity, the exportation of live stock will be followed by that of frozen meat; (3) owing to the difficulty of obtaining from the shipowners or navigation companies the boats needed for the transportation of live stock intended for exportation, the eommittee thinks that as the State is the sole purchaser of this live stock, it ought to have entire charge of its transportation; (4) it would be in the Government's interest to employ competent persons in the shipping and landing centres to inspect the shipping operation and purehasing of the eattle; (5) it would be advisable to leave plenty of room for private enterprise."

The export of canned, frozen, and salted meats is even now an important industry in the island, some thousands of tons being shipped annually.

The large establishments at Majunga (belonging to Messrs. Vestey Bros.). Diego-Suarez, and Tamatave are busy turning out meat for the French Army. 
The bulk of the beef exported from Madagascar was put up in tins until recently, when the Societe Rochefortaise, from its Tamatave plant, began shipping frozen beef by the ships of the Compagnie Havraise Peninsulaire de Navigation a Vapeur.

The three ships already fitted out with cold storage chambers for the exclusive use of the products of the Societe Rochefortaise can accommolate 200 tons of frozen meat each, which space corresponds with the present capacity of the local storage plant. But this plant is soon to be enlarged so as to be able to store 500 tons of frozen meat, and at least three additional ships are to be fitted out with cold storage chambers of equal capacity. The cold storage space in each of the three ships already being used can be increased to 500 tons.

The question of drawing largely on Madagascar and other French colonial possessions for the meat supply of the French Army and civil population has been under consideration for some time in official and commercial circles in France. Several attempts have been made by private concerns to import live beeves from the island into France, but these trials, it seems, were not encouraging because of the long and severe voyage, especially during the passage through the Red Sea.

Large numbers of Zebu cattle, averaging about 800 lbs. live weight, are being shipped to Salonika for the French troops.

Stuart L. Roussel writes me:- "Madagasear, as anyone may see by a glance at the map, is situated right on the "wool belt' of the Southern Hemisphere, although rather to the north of the great pastoral lands of Australia, South Africa, and South America.

"There is a considerable variety of elimates. The east coast has a heavy rainfall, and no really cold season. The extreme south and the western slopes of the main range of mountains are much drier, and in the sonth we have some very cold weather in winter. The difference between the eastern and western sides of this range of mountains, which extends right throngh the island, is very striking when you travel from Fort Dauphin. Ip to a small village ealled Ranopiso, twentytwo miles from Fort Dauphin, vegetation of the ordinary tropical character and rice fields, mango, and banana trees are conspicuous on all sides. Between Ranopiso and Bevilang ('Many Sancepans'), however, a long range of hills is erossed, and the character of vegetation changes completely. At Bevilang, which is only ten miles from Ranopiso, the vegetation 
is of a unique character, and all the trees are powerfully armed for resisting dronght. In many instances leaves have practically disappeared. The stem has swollen, and seems to take the place of leaves. Then these stems and leaves are covered with a thin film of wax, which acts as a further protection against the evaporation of moisture, while the 'latex' or milky sap, which flows in the bark of so many trees and vines of the comtry, and provides some very good rubber, seems to be intended as a further protection against drought.

"Another protection is needed, however, to prevent the extermination of plants valuable as forage, and this is a protection against cattle itself. This is abundantly provided. I suppose there are more thorns to the square yard in the Ondroy bush than there are to the acre of English forest. The fantsi-holicke, a wonderful tree, which has been compared to a forest of upturned elephant trunks, is covered from the gromnd to its highest tip by thorns about an inch in length, disposed of regular spirals about an ineh or two apart. Between these thorns, and just about the same length, grow small, oval, flat leaves, with the consistence of soft leather.

"The pastures are, however, of greater interest than the bush, and these I must now describe. There are in this part of the country two entirely distinct types of pasture. The one which seems to belong to the ealcareous and sandy regions appears to be ideal pasture for sheep. In fact, the natives eall it 'voln'ny ondry,' or sheep's pasture; it is short and sweet. The other is found mostly in granite regions and generally on eruptive soil. It is called 'danga, and is to this country what the spear grass is to Australia. The seed is not more than ahcut half an inch in length, but it bears a long thread-like appendix. Native sheep, having no wool, do not seem to suffer from the danga, while bullocks, owing to their greater height, only collect it while grazing, and that around their horns and eyes. If it gets into the eye it may, of course, be dangerous, yet, broadly speaking, horned cattle do very well on danga.

"The land on which I settled at first was right in the middle of eruptive and granitic hills, and renowned for its good pasture. The sheep-both native and imported Merinos-did well at first, and my shepherd was delighted with the abundant and rich growth of wool. April came round, however, and with it the seeding season of the danga. We soon saw that there was only one safe course, and that was to keep the Merinos in. For 
one of them, however, it was already too late; internal inflammation had set it, and he died after a week's illness. This was my No. 1, a full-folded Rambouillet, bought from the French National 'Bergerie.'

"I had, however, already looked round and found that between the Mountains of Ambia, where I had settled, and the sea there was a region of beantiful pastures, eovered with voln'ny ondry, and my arrangements were complete to transfer the flock there.

"This transfer was no small matter. What with two cart-loads of purebreds, that were too lazy to walk and too valuable to risk on the road, a load or two of lambs which were too young to walk, and some three hundred ewes, most of them in lamb or with roung, the comparatively short trip-only about sixty miles-took the best part of a week. The crossing of the Mananare and of the Mandrare Rivers were the chief events. The Mandrare is a broad but not very deep river, where the native ewes had the opportunity of showing off their swimming abilities, while the purebreds were passed in a native 'lakana,' or pirogne, cut out of the trunk of a single tree.

"This part of the country appears to be all that can be desired for sheep. The grass is good, there is enough of bush to provide shade and shelter-very little or none of the thorny species described above. There is praetically no rumning water, but a fair supply of good water can be secured underground by digging to a depth of from 20 to $40 \mathrm{ft}$. As the natives will indertake to dig such a well for you at the contraet price of three young bullocks, and you can secure those for $30 /$ - to $£ 2$ each, the undertaking is not ruinous. Well water is, however, only used here for domestic purposes, and sheep and eattle-except cart oxen-are never given water. The fact is that the abundant dew which they get on the grass in the morning is quite sufficient for them. An abstemious breed has thus been evolved under the special circumstances obtaining here, and this remark applies to man as well as to animals. Many villagers have to walk three hours or more to the nearest water, and yet they remain on the hill or in the bush when they might, if they cared, move nearer to a well or a river.

"The rainfall here is irregular, and the land being light and sandy, I must provide for periods of drought. This I am doing by sowing some of the various forage seeds whieh during the last drought have proved so helpful in South Africa to the few farmers who had sown them-phalaris bulbosa, paspalum dilatatum, festuea elatior. I am also trying saltbush, teosinte, cowpeas, and velvet beans. 
"The appearance of a plough, or 'oxen spade,' as [ describe it to the natives, las cansed a great sensation. It is, howerer, as new to the oxen as to the men, and it will take a little time until our oxen can plough a straight furrow.

"The real difficulty as regards land is that of securing any large freehold or even leasehold grazing land. All land is open to allcomers, and as the population, though not very large, is pretty well distributed over the whole country-side, it is difficult to secure from the Government the exclusive use of any large area.

"You will no doubt inquire, "What about the native sheep and cattle?' Sheep are fairly large and strong, mostly white, with black or brown spots. In first erosses with IIerinos there seems to be very little black, mostly white and brown. As far as I can judge at present, the brown is short kemp, while the longer wool is white. Thus a lamb which is quite brown at birth, when it seems to be covered with only nativebred kemp, may get quite white in time, when the wool appears.

"As far as 1 can judge, both from the experience of British East Africa and from the products of experiments started a few years ago in this country by a Govermment 'vet.,' the second cross is a great improvement on the first. In fact, I have seen two absolutely distinct types of erosses resulting from the experiments made in this country. One has white wool and short brown kemp on the back, and only brown kemp on the belly ; the line of demarcation between the two regions is quite definite. Those sheep I take to be first crosses, viz., halfbred, or crosses between halfbred.

"The other type has very little or no kemp on the back, and has also the belly covered with wool. Those are, I suppose, second crosses, viz., three-quarter Merinos, and no doubt also sometimes crosses between halfbred, which have taken the Merino eharacteristies both from sire and dam. Unfortunately, the vet. who started these experiments-and who is now dead-was not able to carry them on himself, and distributed his small flock amongst the military and other Govermment ofticials of the various surrounding stations. There they multiplierl, and were appreciated on account of the superior meat they provided the 'mess' with, but systematic breeding was discontinned. and no record kept of the crosses.

"What I have seen of these small flocks goes to show, however, that improvement in the wool can be rapidly secured, but also that with indiscriminate breeding there can be an equally rapid 
reversion to the native type. I have seen in these flocks sheep which I was told were crossbred, but which I certainly would have taken for pure native.

"I tried at first hand-serving, and kept the rams separate from the flock. I found, however, that this was very slow work, and that the ewes were somewhat terrified by their macenstomed mates. I am, therefore, now letting the rams and ewes rum together, and breeding proceeds apace.

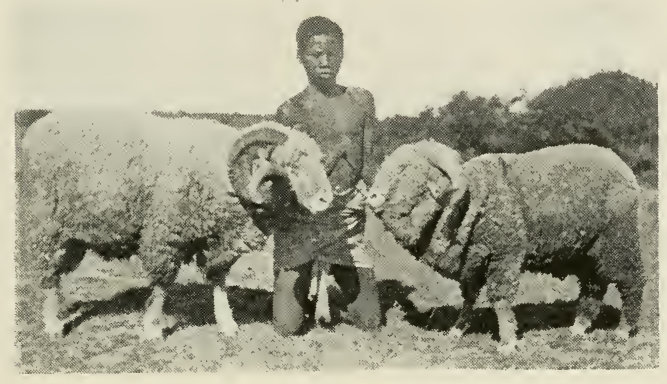

SoIssonnais and Ramboulllet Rams.

Held together by "Tanosy", shepherd.

"Summarising, I think that there are excellent prospects in this country. The land difficulty may make it necessary to adopt another system than in Australia. In fact, I am now considering a scheme for working hand in hand with the native-I providing the rams and they the ewes and the pasture under their own supervision. I would thus limit myself to the breeding of stud rams, for which sufficient land ean be secured. This or some other method must be evolved for getting round the land difficulty, as this comntry appears to have great possibilities for wool-growing, although, as far as I know, it does not so far export one bale or even $1 \mathrm{lb}$. of wool."

Mr. W. Sutherland, Ambohijanahary, Ambatondrazaka, Madagascar, writes me that there are searcely any English eattle breeders in the country. He says: "There is the Cie Generale Frigorifique a Majunga. The manager is an Australian, and there are a number of Englishmen and Anstralians employed there. The eattle are at present nearly all owned by natives, 
excepting a few owned by Frenchmen. Cattle are still eheap here; bullocks fattened on manioc, and giving about $660 \mathrm{lbs}$. of meat nett, are selling at $£ 6$, while those fattened on grass, and giving about $440 \mathrm{lbs}$. of meat, sell at about $\mathfrak{£ 4 . "}$

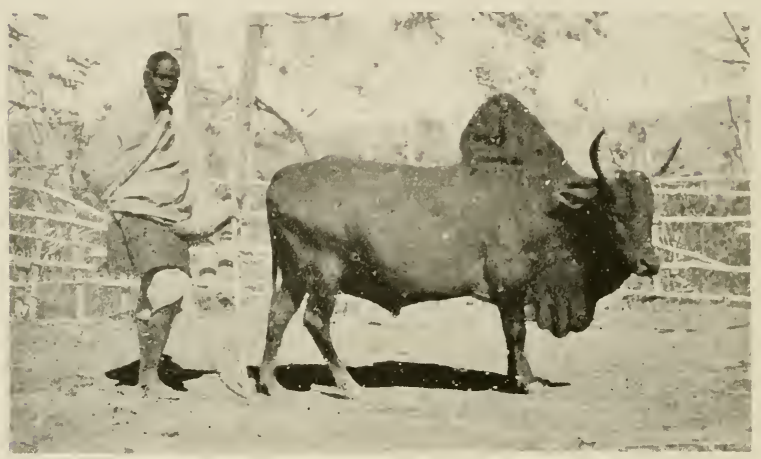

Young Madagascar Bull.

between 3 and 4 years of age and one of the principal herd boys on Mr. Sutherland's property. The hump is a good one for a three-vear-old bull.

Other French colonies from which supplies of eattle can be. procured, and where they are only awaiting good modern methods to increase in numbers and quality, are Algeria, Cartboja, West Africa, and Moroceo. 
The rapid development of British East Afriea is little short of marvellous in view of the many difficulties with which settler's have had to contend. To the Imperial East Africa Company is due the credit of first opening up the country, but after years of struggle its charters were surrendered to the Crown, and some eighteen or nineteen years ago, the only importance the country had in the minds of outsiders was derived from the fierce political strife which took place over the construction of the Uganda railway as a backdoor to Egypt. This undertaking was derided as a useless waste of money which would never bring an adequate return, yet within ten years of its enm. pletion it earned nearly $2 \frac{1}{2}$ per cent. on its extravagant cost of over $£ 5,000,000$, in 1913 it earned $3 \frac{1}{2}$ per cent., and since then has been increasing in prosperity yearly. It is now inadequate to the needs of the comntry. The main line has a length of 584 miles, and links the Indian Ocean with Lake Victoria Nyanza, upon which is a fine fleet of steamers. Feeders or branch lines have come into existence, and further extensions are being carried out.

The climate, although the country is on the Equator, is magnificent. This is aceounted for by the fact that the area suit. able for white settlement consists of vast tablelands rumning up from 4000 to $9000 \mathrm{ft}$. in height, and culminating in the perpetual snows of Mount Kenia at an elevation of over 16,000 ft. These tabelands are of great fertility, blessed with an abundant rainfall, and in little more than fourteen years over 7000 white people have made their homes in a country which for centuries supported nothing but savages and teeming herds of game. Civilisation now exists in the midst of savagery. A scantilyclad native may be seen intelligently using a telephone or seated in his master's motor car. The settler when tired of working may take up his rifle and shoot a gazelle for meat, or seek the excitement of a battle with elephant, lion, or rhinoceros, and then return to his comfortable club or electric-lit home!

Fourteen years ago land could be bought or leased from the Government at a nominal figure, but settlers found it hard to make both ends meet owing to the absence of markets for their produce. Picked farms change hands for a mere song, and many were surrendered to the Government. To-day welldeveloped coffee and sisal hemp plantations are vielding rich returns to their owners. Thousands of aeres are under wattle, maize, wheat, and beans. Sawmills are at work in the forests; 
orehards are yielding their fruit. Probably there is no richer pasture in the world than exists in some parts of British East Africa, and the many stock diseases which used to be rife are rapidly disappearing before seientific investigation and treatment. Inoeulation provides immunity to rinderpest, dipping prevents the dreaded East Coast fever, and to-day it is found possible to graze highly-susceptible imported stock where a few rears ago the hardier native cattle suceumbed. There seems little doubt, therefore, that the highlands of British East Africa are likely to develop a great cattle industry.

Fourteen years ago infrequent steamers dropped casual passengers in Mombasa. Two traius a week ran up to the highlands, and for several years in Nairobi the trains were an event of such importance that elergymen protested against one of the trains arriving on Sunday in that it drew away nearly their entire congregation! Nairobi consisted of the Government and railway oftices and quarters, one or two white tradesmen, the bazaar, and a few other Indian shops. Metalled roads there were none outside the railway quarters. The Governmentroad, though laid out, was a quagmire bordered by a few beginnings of buildings. So little did some people believe in East Africa that a deputation of prospective settlers was informed by the Provincial Commissioner that British East Africa was not a country for white settlement, and that they were not wanted!

Turning to the land side of the question, wonderful advance is shown. In 1904 the majority of the settlers had their holdings in the Kyambu district, and even in that fertile area many found it impossible to make both ends meet. Land was practically valueless, and quite a large number of farms ehanged hands for a mere song, or were surrendered to the Government. It is true a slight boom set in during the year owing to the rapid influx of new settlers, but when the subsequent reaction came things were worse than ever, and the optimists of the country could have easily been counted on one's fingers. Up country the position was almost worse than round Nairobi; quarantine had brought the stock trade to a standstill; depression was everywhere. Land then to be had for the asking has increased in value by leaps and bounds until improved Kyambu coffee farms have changed hands at over $£ 25$ an acre, and unimproved land at $£ 12$ and over an acre. Many of the big grazing areas throughout the country have proved valuable agricultural lands, and have been split up into small blocks selling at up to $£ 2$ and $£ 3$ an acre. Everywhere a steady increase in values has taken place. 
However, it is no place for a man without capital, all manual labour being done by natives or Indian artisans. On the other hand, it offers great attractions to the young man of moderate means, and enterprising enough to grapple with new conditions.

Sheep are of a very poor class, being mostly grades between the native ewe, fat tailed, and the purebred Merino ram. Purebreds imported direct into the country do not do well, and apparently it is not advisable to bring in high-priced rams, for they deteriorate tremendously. A ram carrying a good dense fleece, with good character and plenty of staple, will in twelve months' time develop into a haggard-looking creature, with short, hard, weak and altogether bad wool. If in a show a $£ 100$ ram was awarded 95 points, and a $£ 40$ sheep secured 70 , then under similar conditions, and in a short space of time, they will both be reduced to about 30 points. Again, should the progeny of a high-priced ram be very good, it also seems to go back later on. Therefore, at present, it is too early to pay high prices for sheep. Some farmers have gone in for the purebred Merinos, which were imported from South Africa, but, as compared with the grades, they do not do well. The most favourable results are obtained from crossing the Merino ram with the native ewe, for the mothers are acclimatised, having been in the country many years, which, of course, is a great advantage to the offspring. Then, again, the Merino ram is erossed with the halfbred, and so on until it is exceedingly difficult to distinguish a fourth cross from a half Merino. Stockowners have not gone much further than this, for the sheep industry is still in its infancy, but in those few instances where they have reached the fifth and sixth cross, the owners are not well pleased, for they say that the lambs are mostly very miserable and difficult to raise.

It is not surprising that sheep do not do well, for in the first place good sheepmen are exceedingly few, whilst the conditions under which sheep live are far from being desirable. The rule is for one or two "boys" to herd a mob of about 1000 during the day, and for one "boy" to watch them at night. The sheep are generally put into "bomas" (brush yards) at night, and unless these "bomas" are frequently changed, they get into a filthy state. It is often the ease that they are not renewed as frequently as they should be, with the result that the sheep have to camp on what is practically a manure heap.

Three great things to contend with are disease, stealing, and wild animals. There are many diseases from which sheep suffer, 
including seab, tick, wire worm, nose disease, and blue tongue, but by plenty of attention most of them ean be kept in check. The stealing, which is carried on by the natives, is perhaps worse than anything else, and is, indeed, very difficult to deal with, for it is mostly done during the night, and the trouble is that one's own herders are often "in" with the thieves. The wild animals are becoming fewer as the country gets more settled, but still they aceount for a good many deaths.

Cattle do very well, and there is no doubt that this will some day be a great eattle country. Excellent results are obtained by crossing native cows with purebred bulls, and it is astonishing that the hump that is so prominent in the mother is, in the majority of eases, entirely lost in the progeny. The worst diseases amongst cattle are East Coast fever and rinderpest, also gall sickness is troublesome. By systematic dipping, East Coast fever can be absolutely avoided, and with stringent quarantine laws, and by inoculation, rinderpest can be kept well in hand. In the majority of eases gall sickness ean be enred. Native cows sell at prices ranging from $£ 6$ to $£ 9$, while halfbred cows sell from $£ 15$ to $£ 20$.

Between Nairobi and Sultan Hamid there is very good country for stock in many parts, particularly the Athi plains, but the ticks are very plentiful indeed on these plains, and without regular dipping stock would fare very badly there. The very large herds of game on the Athi plains are an excellent proof of the good qualities of the grasses there. There is a grass on these plains almost identically the same as Rhodes grass, but it does not grow as high as this famous variety of the dub grass.

There is no doubt that the Athi plains will some day carry large herds of eattle. The carrying eapacity of this part is very high, but the grasses are rather inclined to be watery, and the stock fattenet here will not have good kidney fat. The condition generally will be soft without artificial feeding, and stock will quickly lose their condition if travelled far by road or rail.

The rainfall at Athi River Station averages about 25 inches. Around Nairobi the country generally is too valuable as coffee land to think of using it for carrying cattle.

Further west beautiful country is found at Naivasha and Nakuru, and cattle do very well indeed there, but as many parts will become very valuable as coffee lands probably eattle will not be raised there in large numbers. The rainfall at Naivasha averages 25 inches, and at Nakuru 35 inches, so the grasses are generally very green and look beautiful, but they are watery, 
and hard eondition on stock cannot be expected without artificial aid. The earrying eapacity is high here also. Dry countries are always better cattle countries than wet countries. Grasses always eontain more nutriment in the former.

There are many parts of British East Africa spoken of as being good cattle country that lie to the north of the line after passing Nairobi.

The best fattening country in British East Africa is around Mouyuni and Maktua, and to the north of this part. The country there is very dry, but the grasses are full of nutriment. Water is very searce in these parts. As regards "German" East Africa, the good cattle country seems limited to a small area comparatively. The country around Iringa is really good cattle country. There are no tsetse flies there, and it is supposed that horse sickness is nnknown.

Now the war is over there will be a great demand for stud eattle for British East Africa. The first thing that impresses the newcomers is the varied character of the plains and the quality of the herbage growing thereon. As one gazes from the window of the spacious coaches of the Uganda railway, which traverses the whole length of the Protectorate, one sees vast expanses of veldt equal, if not superior, to any in South Africa, teeming with game of all description, giraffe, zebra, and a dozen varieties of antelope, all "fat as butter," and all apparently in excellent health. Here and there, at certain seasons, may also be seen vast mobs of cattle and sheep belonging to the Masai, a very wealthy pastoral community. The best eattle country in the Naivasha district is to be found on the Kinangop Plateau, a tableland lying between the Lake and the Aberdare Mountains, at an elevation ranging from 7000 to $9000 \mathrm{ft}$. above sea-level. The farms on this plateau average 5000 or more acres each, and excellent work has been done during recent years by use of purebred bulls upon the native stock. One end of the Kinangop Platean forms part of the big tract of 500 square miles owned by the East African Syndicate. West of this and extending from within a few miles of Gilgil up to Laikipia, the former home of the Northern Masai, lies a magnificent tract of country eminently suited to eattle.

Much of this country lies at an elevation of $9000 \mathrm{ft}$. above sea-level, so that the cold nights encourage the growth of plenty of hair, whilst disease is almost unheard of, which renders dipping unnecessary.

The farms in this district are large, and subdivision is gradually being effected by some of the owners, 
so that a few years hence much of this land should earry its full share of stock. The herbage is all that eattle can desire, red and white clover being abundant, in addition to a great variety of natural grasses.

Reference must be made to the native stock of British East Africa, for it is upon the native breeds, which are most unpromising looking beasts, undersized, with drooping hindquarter's and of all colours, that the improved Asiatic Zebu or humped breed are first set to improve. These eattle are hardy and good breeders, and soon fatten upon grass alone. They live out of doors in all weathers, and although, as already indicated, their milking qualities have been impaired by generations of mismanagement, the milk is exceedingly rich in butter fat. The lactation period is short, but in spite of its failings the native cow responds to improvement in a truly marvellous manner.

The result of the first cross with a bull of any pure breed is almost invariably a calf which is scarcely recognisable as the offspring of its mother. The hump disappears, the hindquarters become straightened out, the ribs are better sprung, and more often than not the ealf shows the character and colour of its sire, whilst in size it far surpasses any of its low-born relatives. These ealves thrive and grow rapidly, and at two years of age are worth practically double the value of their dam. Of course, the improvement effected by the second and third cross is not so clearly marked as the first, but so much do the offspring partake of the character of the purebred parent that it is frequently almost impossible to distinguish a three-quarter from a purebred heifer.

Mr. Duncan Carson, of Sydney, wrote lately in The Pastoral Review as follows:-

"Paying a visit to British East Africa for the second time, one eannot fail to be struck by two facts-one, the marvellous increase in the values paid for land, the other the want of justification for such an advance, the exception being land suitable for coffee. With this crop, returns from the few plantations which are bearing, it is stated, show profits of over $£ 40$ per acre, so high values for the land are justifiable.

"On the oceasion of my first visit what struck me as curious was the great amount of faith held by practically all the settlers in the future of the country, and the extremely rare cases where they (the settlers) were attempting to justify this faith by bucking in in raising stock or erops to show the returns the land was eapable of producing. 
"Strange as this may appear, this remains one of the curiosities of the position. Many of the settlers, both young and middleaged, appear as if they took up the land with the expectations of making a good rise out of the unearned increment, not with the desire to secure a good income from the prodncts of that land, and show little desire for real hard work.

"As in all new countries, it is the man, young or old, who is capable of turning the land to best aceount, either by hard work with his hands or brains in directing his labour, who is of the greatest value to the country.

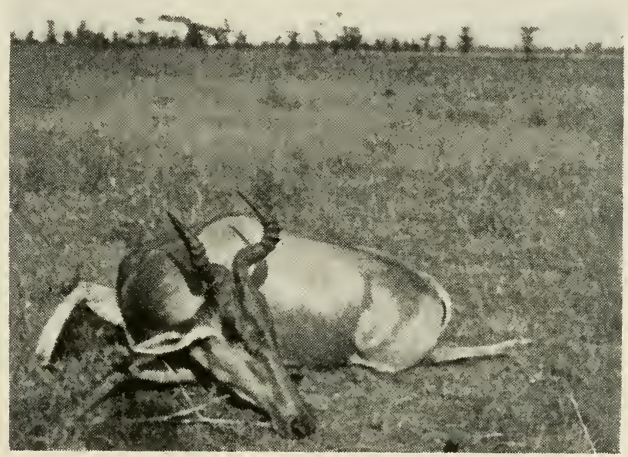

CoNgoni, Shot BY Mr. DUNCAN Carson.

"Unfortunately, many of the settlers appear to think by habiting the land, by running a few head of cattle or sheep, by cultivating a small area, that they are doing all that ean be expected of them. Many even do less than that. For these men it has been fortunate that the land speculators have come along and given them high prices, but it is unfortunate for the next man who desires that block that he has to give the speculator his profit and pay a price when there are few actual returns from the property, in some eases no returns, to show what is the real value of the place. Interest is at a high rate, and money is borrowed from the private lenders at from 10 up to, I believe, 15 per cent., so that only high returns from the farms would justify the prices, from $£ 2$ up to $£ 3$ per acre. which are paid for grazing propositions. 
"Taking a rough and rapid survey of the position, it means that the country even yet has not settled into its stride. Some few, probably thirty in British East Africa, are doing well out of coffee. Some few-probably a dozen-are doing well out of sisal hemp. Others make returns from butter, the sale of surplus cattle and sheep or produce.

"At the time of my former visit the comntry for British East Africa was very dry but the quantity of grass that elothed the pastures at this visit made the country very attractive, but it would require a long sojourn in the comntry before one could say which were the grasses most suitable for stock, as settlers in different districts have widely different ideas as to the feeding virtues of the different grasses, herbs, and shrubs, and also as to the carrying capacity of the land. An Australian used to the carrying capacity in Australia naturally forms his own idea, but that is best kept to oneself; but, taking it on the whole, British East Africa is more a cattle country than at any rate Merino sheep.

"There are some small areas near Naivasha, and to a much larger extent the country in the Southern Guaso Nyiro, now held by the Masai tribe, which an Australian would consider

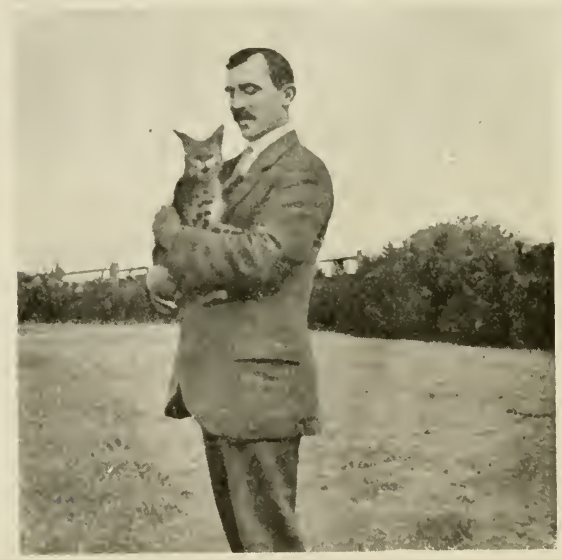

Mr. Megregor, Maxager of The Nawasha Stud Farm, B.E.A., ANd Serval Cat. 
good grade Merino sheep country; but the Masai country is not available, and I did not see the other distriets, where reports say Merinos would thrive-at any rate the area is limited.

"The Merinos require drenching fairly frequntly for wire and tape worm, and are all dipped, but looked very well indeed at the time of my visit.

"The settlers are keen on getting grade bulls for crossing with the native eattle, and give $£ 50$ and over for bulls that few Australian breeders would look at, whilst purebred Shorthorns of quite moderate grade would realise 60 to 90 guineas. Unfortumately, I did not see Lord Delamere's herd, but I understand it is of a high grade, but several of the more enterprising settlers are getting quite nice herds of pure and grade eattle that seem to do well on the natural pasturage.

"What appealed to me in shooting through the large Masai reserve in the Southern Guaso Nyiro, and seeing the very large herds held by that tribe, was that it would be well worth a settler's energies to get a pick of the native Masai cattle, select a good bull, and then start and improve that breed. There is plenty of room for it, and one is encouraged in this, as, were one to select, say, the top s 0 per cent. out of the huge herds held by the Masai, one would have a lot of exeellent animals of that breed, valuable not only as beef oxen, but also as trek oxen. The Masai, whilst sometimes using good bulls, freruently breed from a bull because they fancy his colour, which is generally a freak, sueh as a spotted black and white or one with some brindled markings; whilst many of the dum-eoloured, or reddish brown, or fawn-colonred animals, are quite attractive, and would be the type to maintain and improve.

"Whilst the comntry has not yet got into its stride, and will never be a country for large individual herds, it undoubtedly holds great possibilities of quick advancement for the young man who can keep away from the Nairobi and Nakura bars, and will be content to put in some good solid work in making a home for himself. Formerly the diseases in the eattle were enough to frighten the intended settler, but rinderpest, I was assured by the Government expert, was readily held in cheek by inoculation, whilst the dreaded East Coast iever is quite easily stepped by dipping the eattle every three days for a period of six months. For an Australian this seems a lot of work, but as a settler with 300 to 400 head of eattle is looked upon as having a large herd, the dipping takes the native herdsmen 
(who become quite expert at putting the eattle through) from an hour to two hours. One good adrance has been the erection of these dips at the various farms. Unfortunately for the employer of native labour, the introduction of so mauy of the Indian coolies has caused the adoption of their intensely slow methods of working. If a road is being made the material is carried in small baskets, mostly put into basket by hand, and then carried at a very slow walk (about a two-miles per hour rate) to its destination. To make the most of the available labour this wants altering, though it will take a strong man to do it, but it would make the labour twice as efficient. Labour is much dearer than formerly, but still ranges from 6 to 8 rupees a month with food (posho), costing, say, 3 rupees average, or well nnder a pound a month, including food. The hours worked vary a great deal, and one settler gets on with his labour much better than others, but it can be taken as a fact that labour is getting dearer and more difficult each year. At the same time, the better men are becoming more efficient. After all, the natives do not require much money. The young men want sufficient to buy one or two wives-the elder men more wives, so that they ean retire from work, and get their shambas (cultivated plot) worked by their wives. With most tribes it is the wives who do the heary work. I met two or three influential settlers who considered that the eure for the nagging wife or militant suffragette would be the taking of several wives by the Europeans. The nagging wife would soon be left to cool her ideas, and it is quite possible that many of our marriage difficulties might be solved in that way.

"The country, where the elevation is over $5000 \mathrm{ft}$., is mainly a very healthy one for Europeans, the climate delightful, with very slight variations the whole year round. At the lower levels and in Iganda, of course, fever is prevalent, and the European has to take considerable care to avoid mosquitoes and fly bites, and thus keep as free as possible from malaria. In Uganda, which I did not visit at this time, the prospects are stated to be very great for coffee, rubber, and cocoa, whilst cotton affords a not very high retnrn. To one who is tired of the never-ending socialistic trend of Australian polities, British East Africa offers not only the prospects of a very remunerative field for his energies, but at the same time a very healthy spot in which to spend his days whilst he can indulge in big game shooting to his heart's content." 
In this part of Africa, until recently owned by the Germans, there are excellent grazing lands in the higher country. The Herero tribe are nomadic eattle owners, and possess large herds in Damaraland. It is almost purely a pastoral eountry, agriculture being confined to the territory around Grootfontein, Amboland, and the Okavango Valley. Since the rinderpest in 1897 the comntry has been practically free from serious diseases, and stock-raising ean be successfully and cheaply carried out. Liebig's Company have recently obtained a big area of eattle country, which is a proof of its value. It is quite probable that under good government this country has a great future before it for cattle and sheep raising.

\section{EGYPT AND SOUDAN.}

In Egypt there are very large numbers of cattle, nearly every farmer keeps a few head, and these are fed and fattened on the luxurious fields of the Delta. During the last few years the Egyptian Govermment has taken steps to improve the quality and size of these.

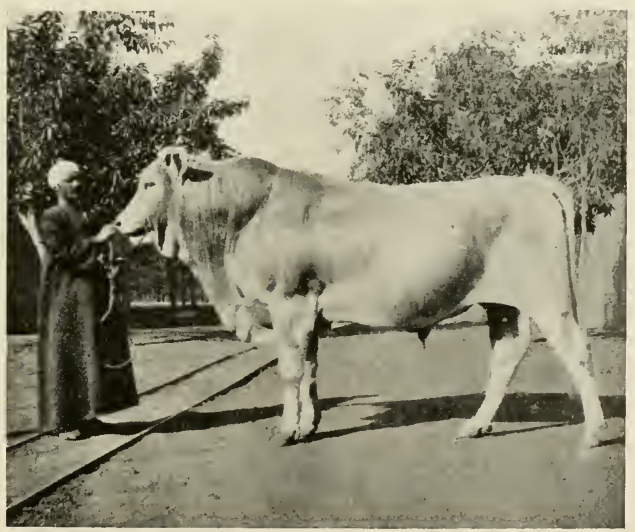

Native Egyptian Bull, Diarb, light dun, 7 years old.

Weight, 2226 lbs. 
Some seren miles out of ('airo, at Shabri, there is in existenee, under the able control of $\mathrm{Mr}$. A. ('. Branch, a large stuel of thoroughbred and Arab horses, eattle, and sheep. This belongs to the Sultanieh Agricultural Society, and was instituted some years ago by I'rince I Iassan.

Accepting a kind invitation by Mr. Branch, I motored out reecntly to inspect it. The drive was interesting, as I passed through some of the richest land in Egypt, rented at $£ 22$ per acre, and worth up to $£ 3.50$ per acre. Every deseription of erop looked in magnitieent eontition. Veritably Egypt is a land of plenty. On arrival I drew up at the donr of a big brick pile of buildings, and was taken to see the stock. Mr. Braneh's profession is that of improving the native stoek, and l saw some most interesting results. Naturally mistakes liave been made, but that ean be taken for grantel. For instance, Norfolk rams were introdued into the native fat-tailed sheep, with the prosult that the tail was bred ont; then it was discovered that no native would buy the sheep without the fat tails, so now they are busy breeding the tail hack again. Egypt has very few animals giving mueh fat, and the sheep's tails, which are almost entirely fat, giving uj, to $\mathrm{s}$ lhs. Weight, are naturally of great value.

The first bull brought out was a real corker, weighing 2200 lhs., a native bull of a light dun colour, ealled Diarb, seven years old. The next, a little darker in colour, and nearly as big, Ibn

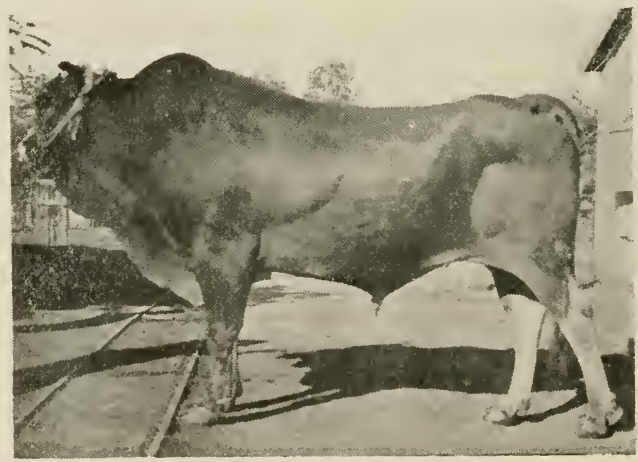

Natile Bull, IBN SHAKei, 6 Years old. 
Shakei, six years old. Then I saw a younger one, three years old, called lbn Khalifa, and next a gigantic buffalo bull.

A group of very pretty three-year-old cows by Ibn shakei quite took my fancy. A buffalo cow of enormous proportions came next; this cow gives four gallons of milk per day, with 8 per cent. butter fat. I finished up the cattle by a view of several beautiful young calves, showing what vast improvement can be made in the native stock by judicious breeding.

The Soudan also promises to be a good country for eattle, and a port now in existence in the Red Sea will give it an ontlet for the exports of live stcek and later on for frozen meat. There are great opportmities for the eattle industry on the Nile.

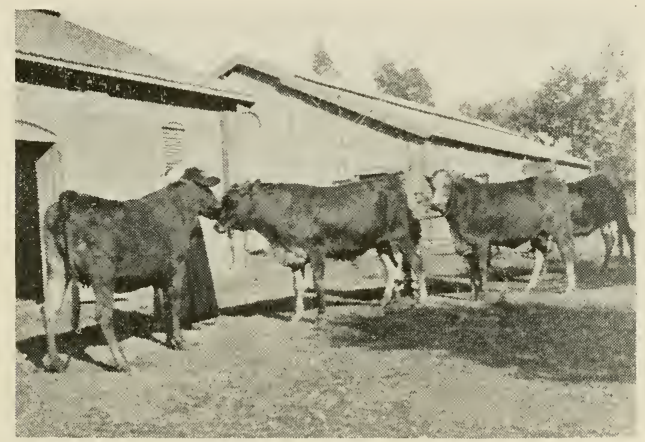

Group of Cows, BY IBN SHAKEI, 3 yeARs oLd,

\section{NIGERIA.}

It is now some three years since the immense cattle reserves existing in Nigeria began to be discovered and appreciated. This appreciation first came to a man who travelled two and a half years in the cattle regious of Nigeria and a short way over the borders into French, and what was previously German, colonies. This was Mr. speed, a man of wide experience, who not only carefully collected data from interviews with residents, district officials, and the more important chiefs, but also put his observations to the test in a practical way. He fonnd that there were not less than five million head of cattle. Besides Sir Frederick Lugard, the Governor-General, Mr. Speed saw Mr. 
Bonar Law and Mr. Steel Maitland on this matter, with a view to seemring adequate reserves of land to allow for eollecting and fattening prior to railing to Lagos. This was the first step necessary for capital to be put up to seeure the erection of refrigerators, ete.

As a result of his energies arrangements were made between the Nigerian Company, Miller Brothers and the African Assoeiation to finanee the enterprise as oecasion arose, and Mr. Speed went to Nigeria again to carry out the initial steps. Unfortunately he died soon after reaching Nigeria. Nothing has been done since the removal by death of this foreeful personality, who from long experience in Australia and Rhodesia, was a great judge of eattle, who had moreover accumulated a vast deal of information regarding conditions in Nigeria, and had actually experimented on a fair scale in fattening cattle before railing them to Lagos. This man could, without doubt, have guided into existenee a vast enterprise, had he lived. An able man whom Mr. Speed sent out, a Canadian, Mr. Claude P. Evans, has spent over a year eovering the ground previously traversed by Mr. Speed, and fully confirms all his findings. Undoubtedly there is in the country a great natural eattle reservoir, and in view of the growing searcity of meat, it is to be hoped that steps will be taken by British enterprise to tap this new and great supply.

\section{ABYSSINIA, SOMALILAND, AND THE CAMEROONS.}

Abyssinia, Somaliland, and the Cameroons are all countries with more or less native stock, which are all open to improvement. On the high and healthy plateaux of these countries there is ample feed for stock, and the elimate is excellent.

\section{CHINA.}

As new eountries come into the frozen meat exporting arena, and China amongst them, Hongkong, which has long been a meat producer, may be expeeted to eome to the fore. Last year, for example, her meat product exports to the United States of America were valued at $£ 28,000$, as against only $£ 15,000$ in the previous year: while she also sent meat to the Philippines valued at $£ 78,084$, as against $£ 96,762$ worth in 1916 . Frozen beef figured among her exports to the l'hilippines, although this 
ceased with the rise in the exchange which later eventuated. With the return of exchange to a normal level, the comparatively low price of meats in the immediate neighbourhood and the comparatively low cost of labour will doubtless make it practically impossible for American packers to compete with local interests save only in fine and special products.

The Hongkong Dairy Farm Company, Limited, for a considerable period has been experimenting with the packing of meats of different sorts for use in outports and aboard ship, including the tinning of beef and various meat products. It is now announced that the business has passed the experimental stage, and that the concern is arranging to can meats upon a large scale. Already the company has secured practically entire control of the trade in hams, bacon, and similar goods along the China coast, and its goods have been successfully shipped to other parts of the world, including Great Britain.

It has been found by repeated experiments that conditions in the meat-packing trade in this field are vastly different in every way from those in Europe and the United States. The work done in Hongkong so far has been under the superintendence of a British meat expert of many years' experience, and practically everything undertaken on the basis of British practice has been a failure there until methods meeting conditions in Hongkong were worked out. Such an undertaking as the one now being developed is likely to have an important bearing upon the sale of tinned American meats in that field.

Refrigerated steamers are shortly to be put on the route between San Francisco and Tientsin to carry beef from the Shantung and Honan provinces of China. The beef from these provinces is of excellent quality, and far and away the best in China. The quality of this Chinese beef compares, according to statements made by the veterinary of the American troops stationed at Tientsin, very favourably with the Australian beef, while the Russian authorities prefer it by far to the latter. The United States troops in the Philippines are being supplied with Chinese beef.

Recently a large steamer flying the French flag landed 3000 tons of frozen beef at Port Said from China, Manchurian beef of very excellent quality. This is known to have been the second shipment from that quarter, and it is said that other cargoes are being sent. 


\section{SIBERIA.}

Siberia was advaneing as an important factor in live stock produetion. P'etropavlovsk, on the trans-Siberian railway, was the centre of an immense eattle-breeding district, and eonsignments of beef have been male from that region. The number of cattle there rose from 360,000 in 1903 to 770,000 in 1909 , and subsequently the advance has eontinued. Mutton will also be largely exported when the new ways of eommunication provith means of tanping the great outlying pasture lands, and as a proof of their importanee the official returns show $2,000,000$ sheep in Kirghiz Steppes, and 1,300,000 sheep in Akmolinsk, both areas being capable of greater development. In respect to sneh progress, however, the trans-Siberian railway, whilst traversing a rich pastoral zone, leaves some hundreds of miles to the sonth, said to be the most fertile lands of Siberia. The eattle-breeding industry there awaits the impulse of railway remmmication and spitled government. Pig-breeding is of speeial impertance, thanks to cheap and abundant fond supplied by dairies in the Kurgan distriet, whenee large quantities of baeon and pork are exported annually; but the inadequacy of railway transit prevents, for the present, an extension of that trade.

An English firm has ereeted meat works at Barawei. Refrigerator's have bern ereeted at Semipalatinsk, and works are contemplated at Omsk. Stock and game are abundant and cheap, and the elimate is favourable for the frozen meat trade, but what effect the last four year's have had remains to be seen; however, new blos may make things progress after the war is over.

The vast region of Asiatie Russia is practically a new comntry in eattle raising, and has possibilities too numerons to be estimated. From 1905 to 1911 the number of eattle inereased from 5,600,000 to $14,700,000$. Russia was proposing to go in very largely for meehanical refrigeration direetly after the war. Numbers of cold storage buildings were to be ereeted in the principal cattle-growing distriets, ant reeeiving stations with cold storage facilities were to be installed.

I had intended risiting this eountry, and had reeeived my passpert from Earl Grey and letter's from the Russian Government when the war broke out, and I had to caneel the trip. 

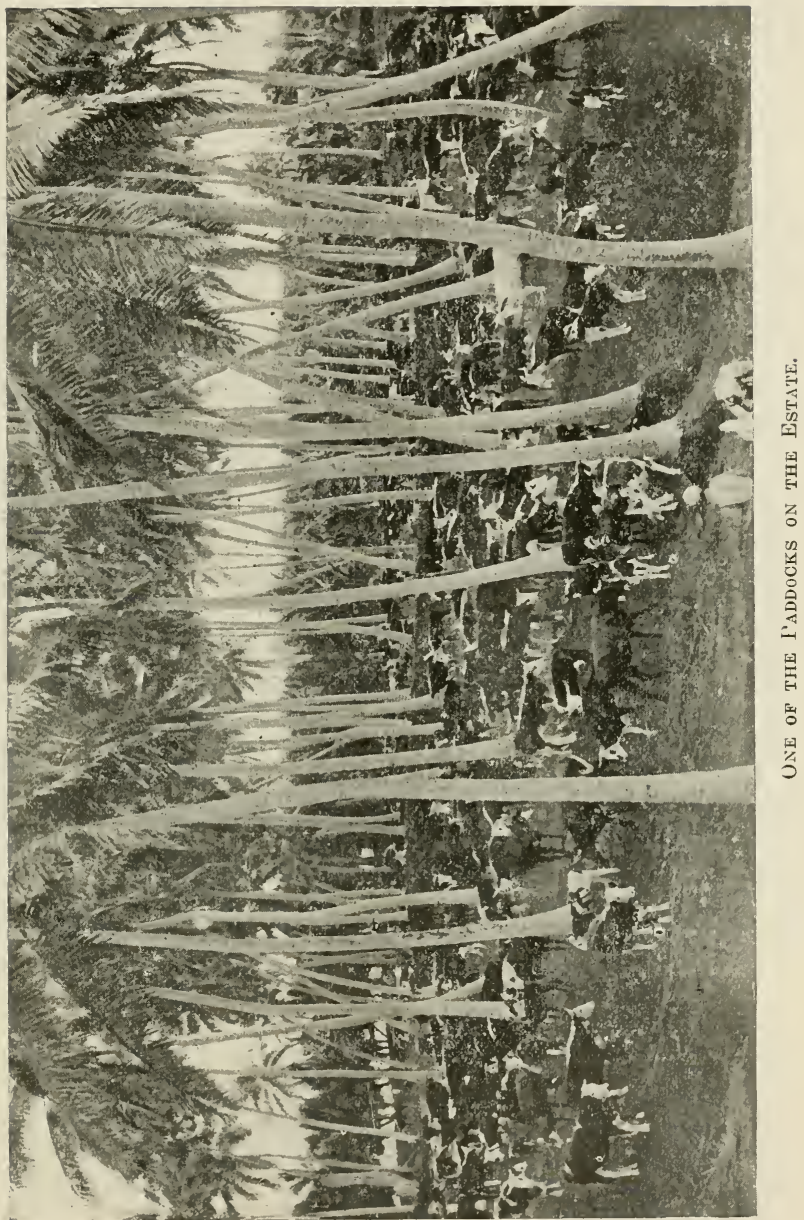
THE P.CIFIC ISLANDS.

There are several large areas in the Pacifie Ocean where eattle raising has been for years a suceessful industry, and at times of seareity in Anstralia some very fine cattle have been marketed from Fiji and New Caledonia. On one island in the Fiji Group there has been for many years a very large herd of

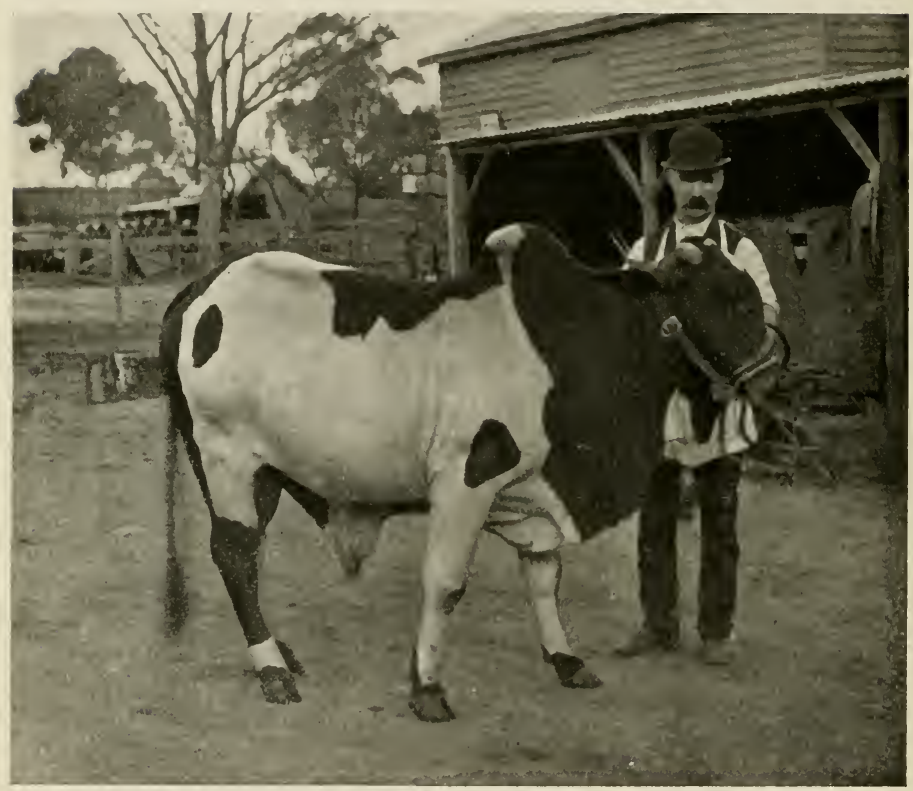

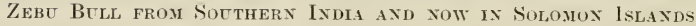
ox the Maligta Plantatios.

Hereford eattle, and every year stud bulls of that breed have been purchased in Australia.

The eattle fatten rapidly on the sensitive plant, and obtain quiek maturity. The drawback has been always the want of markets for the disposal of the bullocks. The peninsula, of about 100,000 aeres, with rich pasture on the French island of Tahiti, 
in the Windward Group, is an ideal spot for cattle-raising, and should be able easily to supply with beef all the ships calling there, and at times have a surplus for export. The same sensitive plant is to be found in luxuriance all over the island. Again, the Sandwich Group, of which Honolulu is the main port, has many cattle owners, and cattle do excellently there.

New Caledonia is a comntry of great possibilities. As a eattle-raising colony, this French possession has a great future. There are already three meat preserving works there, two of them being operated by Australian capital.

\section{JAPAN.}

The Japanese Department of Agriculture and Commerce is spending 30,000 yen (about $£ 3000$ ) annually on the rearing of sheep. This commenced in the financial year 1916-17. About 200 head of sheep have been purchased from England, and others from Australia and New Zealand, and kept on the pastures at Tsukisamushu, Hokkaido.

Should these renewed experiments in sheep-raising in Japan prove remunerative the authorities will take steps for the encouragement of this branch of agriculture among farmers. The Japanese authorities are apparently convinced that sheepraising in Japan will turn out successful, but it should be remembered that much depends on the demand for mutton, which is not an accepted article of food in Japan. 


\section{REVOLETION IN MUTTON STOWAGE.}

33 PER C'ENT' SATING IN SPACE.

The accompanying illustrations show how mutton is dealt with to save space. The carcase is treated as follows:-The mutton when slaughtered is placed on the rail and chilled for 18 to 24

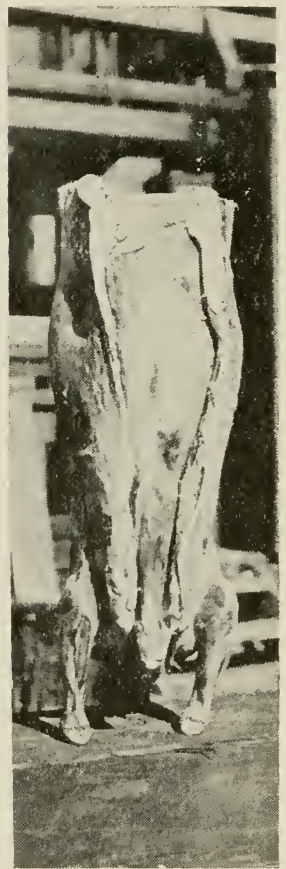

Fig. 1.

Showing where the carcase is eut.

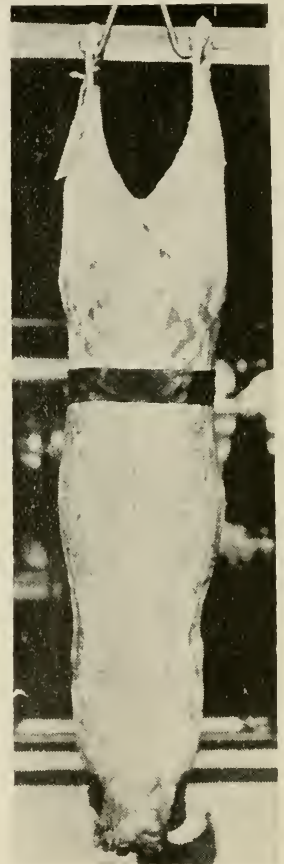

Fig. 2.

The top half inserted sideways in the lower, legs down. 
hours. It is then ent into two pieces across the loin, the trunk falling to the floor and remaining in an upright position. The hind portion is placed sideways legs down into the trunk, and then frozen in the npright position. After freezing it is bagged and stored. Mutton treated in this manner, it is estimated, save from 25 per cent. to 30 per cent. in space, and much more weight can be got in a given space. It really means increasing the capacity of steamers and cold stores to a similar large extent. 


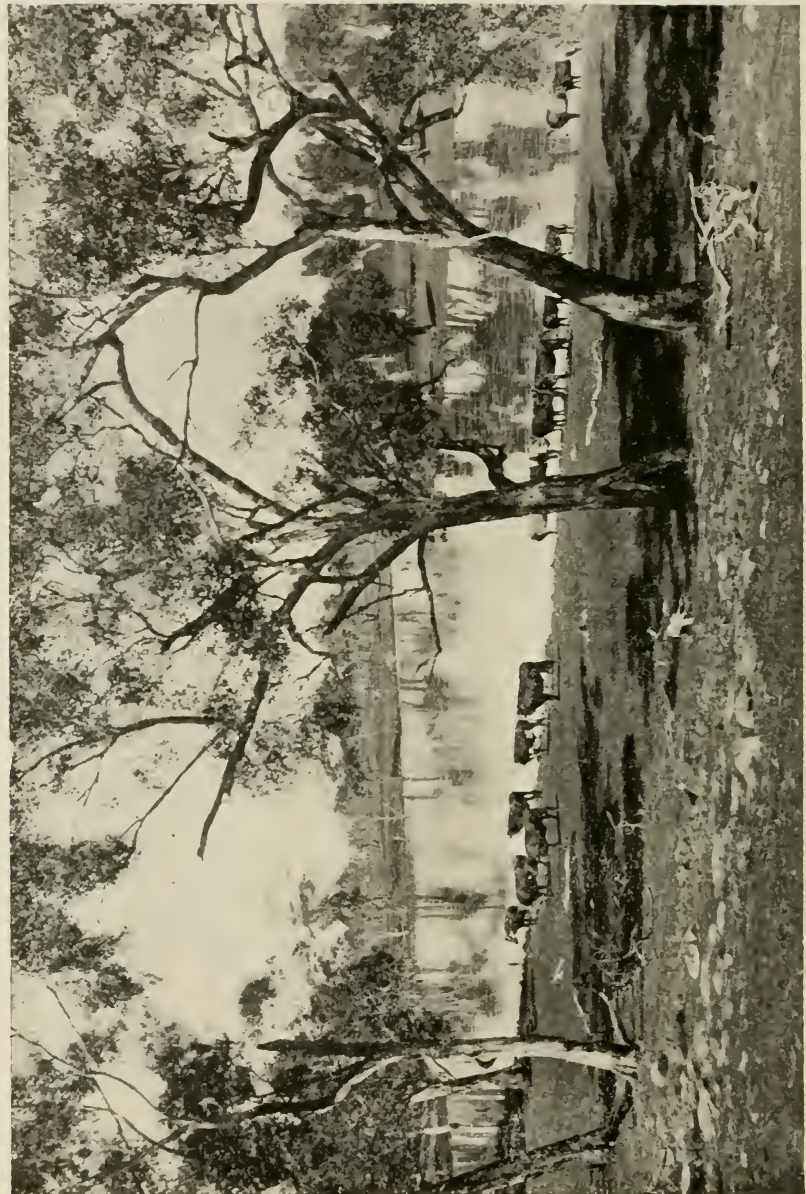




\section{CATTLE PROSPECTS IN WESTERN AUSTRALIA.}

Westem Australia is so big a country, and subject to so many differing conditions, that any general deseription of the eattle industry is impossible; the only way to gain a clear understanding of the position is to take the divisions of the State separately.

When the last statisties were published at the end of 1917, the State possessed 958,484 eattle, as compared with 863,930 at the end of 1916, and 754,377 in 1907. There has then been an apparent steady increase during the last 10 years, but this increase is almost wholly in the Kimberley division, which lies in the extreme north of the State; and, as a matter of fact, the main North-west division, which has been discarding eattle for sheep for many years, has gone back in its numbers.

Kimberley is the eattle end of the country, as will be shown by the following tạble:-

Statistical Division.

East Kimberley

West Kimberley ..

North-west

Gascoyne

Murchison and Goldfield

Agricultural Areas
Cattle at 31 st Dec., 1917.

. 265,604

. . 408,366

. $\quad 61,917$

. 49,890

. $\quad 73.349$ 99,358

959,484

The figures show that East and West Kimberley now possess 673,970 eattle, or more than two-thirds of the herds of the State. The growth in Kimberley has been rapid, as at the end of 1907 the totals were 463,735 for the two Kimberleys, so that the increase in the ten-year period has been roughly fifty per cent.

Kimberley has been one of the most neglected corners of the earth. Blest with magnificent soil and noble rivers, it has been eursed by misgovernment and neglect. When freezing works and camning plants years ago might have given the country a market, eleaned up all the aged cattle, and enconraged the lessees to open out the country, the Kimberley squatter's have only been able to market some 25,000 eattle annually, by shipment to Fremantle, 6 days' steam southwards, or to occasionally get rid of a few thousand store bullocks to Queensland.

The absence of markets has been pronounced, and has for many years indnced a condition of things closely akin to stagnation. Owners have kept down their breeding, as it was no use going 


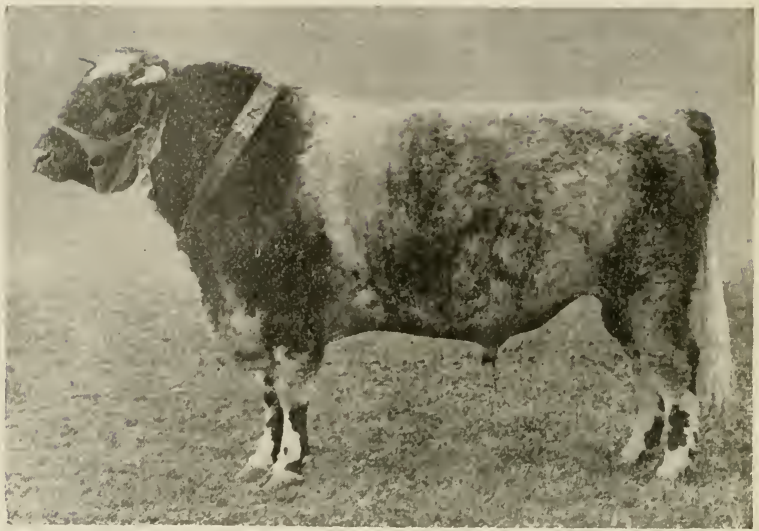

Reserve Champion shorthorn Blll, Brisbane Show, Queensland,

LTNDHehst Royal PeER 11Th

Exhibited by Mr. C. E. MeDougall.

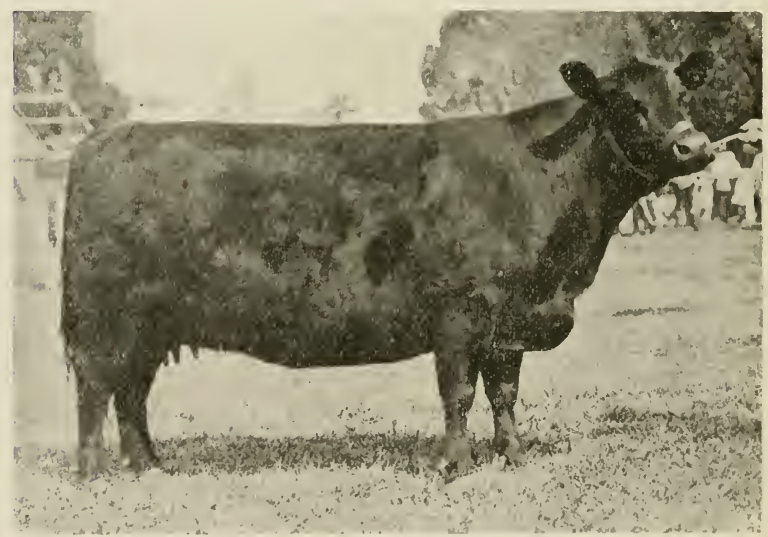

Reserve ChaMpion Aberdeen ANgus Cow, ScotTisil QueEN. BrisbaNe Show, QUEENSLAND.

Exhibited by Mr. G. C. Clark. 
to the expense of improving the back country and carrying more eattle till the rums earned more money than a bare subsistence from the infrequent sales. And consequently the country has never really been used, developed or stocked. All that the lessees have done, up to the present, is to run the frontages of the rivers and leave development till later on. The cattle seldom work back more than seven miles from the rivers, and all the rest of the oceupied rums is really waste. There are still considerable areas which have never been taken up; some of it on account of the blacks, who are troublesome in the back country.

But all accounts agree that there is any amount of room for a big increase in the Kimberley lands when the back eountry is opened ont and provided with water. The West Australian Government has now erected treatment works at Wyndham, and although they are largely a failure in that they have cost a ruinous price to build, and that they can only offer the East Kimberley pastoralist $2 \frac{3}{4} \mathrm{~d}$. $1 \mathrm{~b}$. for his beef instearl of its value on the Queensland eoast, still they will open out some sort of a market for the comntry; and with the dawn of better days the Govermment may perchance write off the $£ 350,000$ to $£ 400,000$ of waste due to Departmentalism and day labour, and hand the concern over to the growers to $\mathrm{rm}$ for themselves. In any ease the Wyndham Works represent the beginning of a new chapter in the history of Kimberley, which will be progressive in exact proportion to the removal of the Government blight upon its marketing facilities, and prosperous as that consummation is effeeted. Some day also freezing works must surely come to Derby, the front of West Kimberley, to terminate the day of cattle shipments southward, and their waste of $100 \mathrm{lbs}$. per bullock, and to ship away the product of the country in cold storage, in tins, tallow, and hides.

Working sonthwards from Kimberley we come to the Northwest and Gascoyne divisions-a huge and partly opened out comntry, rumning some 111,807 cattle, or less than there were 10 years ago, when there were over 122,000 cattle in these provinces. From this country a portion of the beef supply of Perth is drawn, and notwithstanding the importation of 20,000 cattle from Kimberley in 1916, and 10,000 in 1918, the consumptive drain upon the country is more than it can stand. There are not 3,000 bullocks of marketable ages north of Meekatharra and sonth of Wallal to-day : and there is every indication that in a year or two it will be difficult to keep pace with eonsumption. 


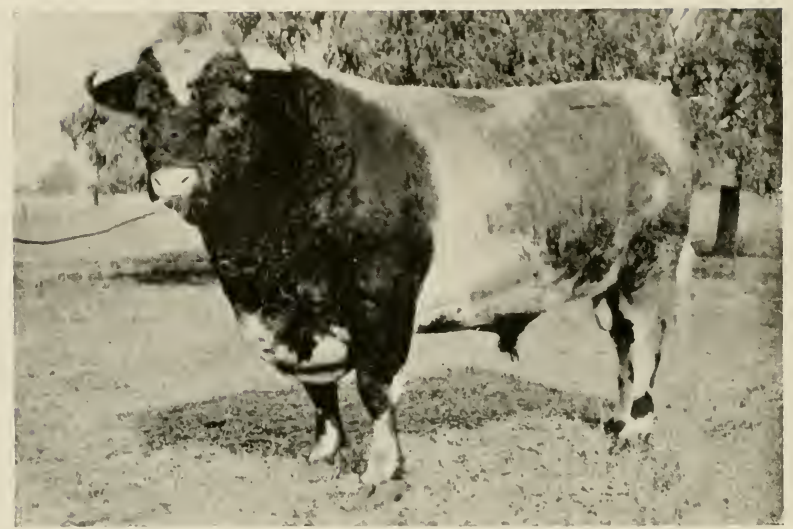

STUd SHORTHORN BULL, BaritoNe, CHAMPION AT SIDNEY Royal Sноw, 1918.

Purchased for 1700 guineas by Mr. John MeMaster, Binnia Downs, New South Wales.

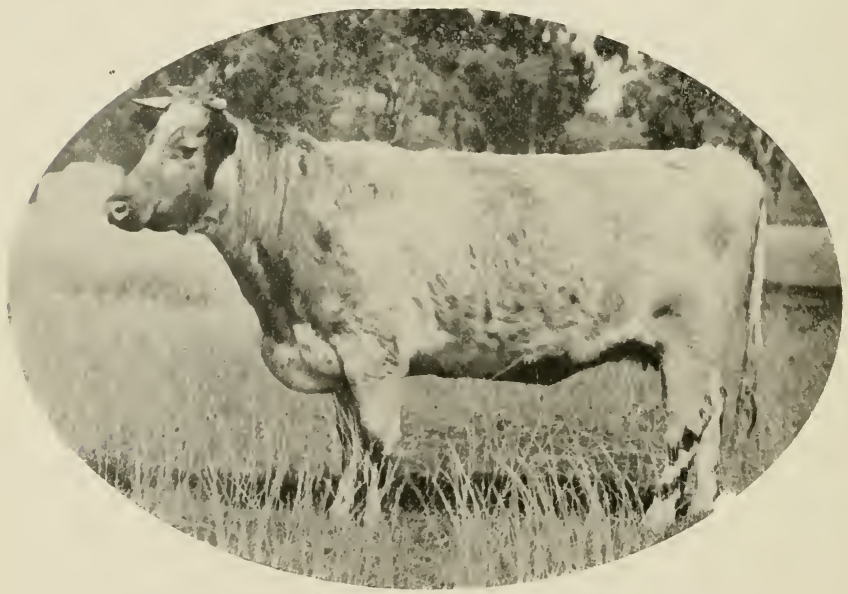

Mr. JOHN MCMASTER's S'TUd SHORTHORN Cow, “(Golden DUChess,', BinNia Dowsis, NEW South WALES. 
There is plenty of eattle country vacant in the North-west, but no one is troubling about breeding. Sheep pay better, and the eattle question is left to look after itself. No doubt, as export develops and the whole country advances, the cattle numbers will increase, and increase considerably.

On the Murchison and the Eastern Goldfields there are some 73,349 cattle, over 20,660 of which are held round Kalgoorlie, which is, for the first time in its brief history, able to eat its own roasts for a considerable portion of the year. There is still much unoceupied country in these divisions, but, served as the country is with railways, it is more likely to increase its sheep numbers than its cattle. The country along the Great Western Railway, too, may probably run some cattle, but the chances are that here as elsewhere sheep will be the objective.

Lastly, we have the agricultural areas of the South-western Division, which ran 120,582 eattle ten years ago, and only counts up 99,358 to-day. The South-west is not a cattle country, and the most that can be hoped for is the development of dairying in the improved country, and a gradual but slow increase, perhaps principally of dairy breeds, and to a lesser degree of beef breeds. But that increase is not likely to be sudden nor considerable.

From this sketch it will be seen that Western Australian increase will be in the tropies and very largely in proportion to the development of cold storage. Southwards, as the population grows, there is little probability of any noticeable increase in the day of this generation. And even if the present figures were doubled they would still be inconsiderable. 


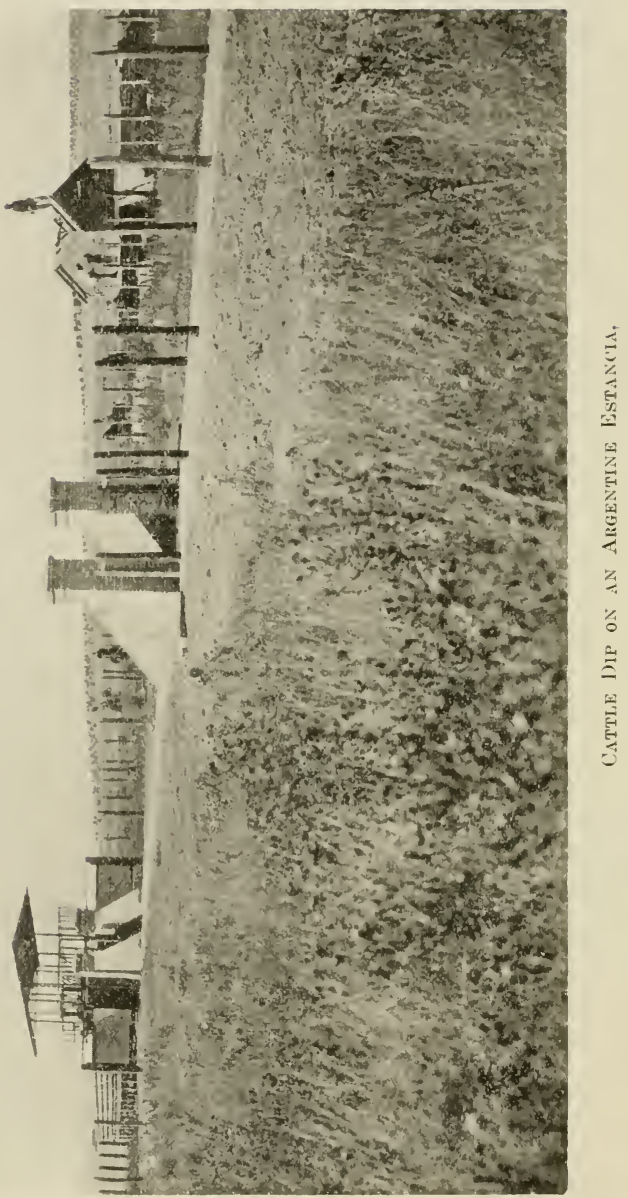


The Director of Rural Economy and Statistics of Argentina recently presented the following report to the Government and a statistical return concerning cattle and the consumption and exportation of meat for the year 1917, with comparative figures for the quinquennial period 1913-1917:-

Total killings during 1917 were as under :-

\begin{tabular}{|c|c|c|c|}
\hline Liniers slaughterhouses . . & $\begin{array}{l}\text { Cattle. } \\
404,231\end{array}$ & $\begin{array}{r}\text { Sheep. } \\
1,030,292\end{array}$ & $\begin{array}{r}\text { Pigৎ. } \\
115,900\end{array}$ \\
\hline $\begin{array}{l}\text { meat freezing works, "saladeros" } \\
\text { and meat factories } \\
\text { the } 2356 \text { municipal and private } \\
\text { slaughterhouses which have sup- }\end{array}$ & $2,496,284$ & $2,233, \AA 96$ & 193353 \\
\hline plied data $\quad \ldots \quad \ldots$ & $1,127,624$ & 521,999 & 77.041 \\
\hline & $4,028,139$ & $3,786,187$ & 396,324 \\
\hline
\end{tabular}

In order to arrive at the total killings for the whole country. it would be necessary to ascertain the number of animals slaughtered on "estancias" and farms for their own meat supplies, and in some small slaughterhouses of which we possess no data. We endeavour, however, to arrive at this total figure by another means, viz.. by taking the number of hides exported and utilised in the country. During 1917 , in round figures, the quantity was $5,873,000$. Compared with the ascertained killings, this figure shows a difference of $1,845,000$, so that our statisties regarding killings comprise over 68.5 per cent. of the total.

\section{C'ou's and steers.}

The proportions of steers and cows slanghtered at "frigorificos" and slaughterhouses, registered during the past seven years, were as under:-

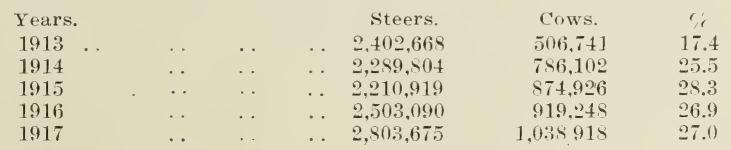

These proportions undergo considerable variation, when we treat of the destination of the animals:-

Liniers

Total Cows and Steers.

Municipal and private slanghterhouses . . $1,070,776$

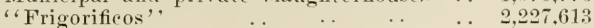

"Saladeros" and preserved meat factories 262.254 of Cows. 


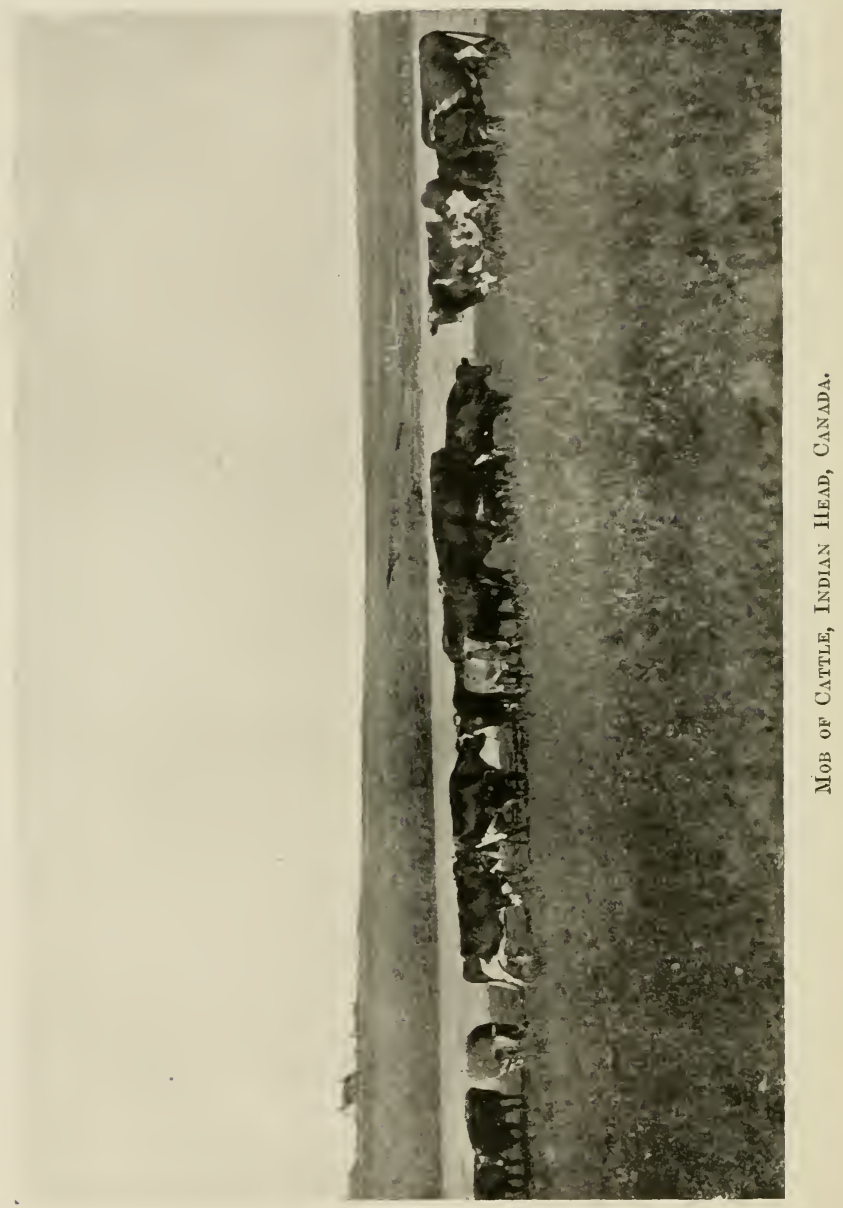


Calves are not included in these comparative returns, but it may be mentioned that they only represented $4 \frac{1}{2}$ per cent. of the total of 4,028,139 indicated above.

\section{Frigorificos and Preserved Meat Factories.}

The figures relative to "frigorifico" killings show a marked increase since 1915, although there have been fluctuations:-

$\begin{array}{lllrrrr}\text { Year. } & & & & \text { Cattle. } & \text { Sheep. } & \text { Pigs. } \\ 1913 & \ldots & \ldots & \ldots & 1,608,983 & 2,489,461 & 4,756 \\ 1914 & \ldots & \ldots & \ldots & 1,588,878 & 2,859,164 & 13,977 \\ 1915 & \ldots & \ldots & \ldots & 1,640,846 & 1,948,099 & 43,172 \\ 1916 & \ldots & \ldots & \ldots & 2,101,550 & 2,646,713 & 75,592 \\ 1917 & \ldots & \ldots & \ldots & 2,496,284 & 2,233,896 & 193,383\end{array}$

By converting the above figures into tons, we arrive at a more just appreciation of their importance from a commercial point of view. The following table shows in tons the quantity of meat which has left the "frigorificos" and meat factories for export and for home consumption :-

\begin{tabular}{|c|c|c|c|c|c|}
\hline Year. & & Beef. & $\begin{array}{c}\text { Mutton } \\
\text { and Lamb. }\end{array}$ & $\begin{array}{c}\text { Pig } \\
\text { Meat. }\end{array}$ & Totals. \\
\hline 1913 & & 519,633 & 65,420 & 357 & 585,410 \\
\hline 1914 & . & 511,296 & 73,811 & 791 & 585,898 \\
\hline 1915 & . & . $\quad 522,557$ & 50.765 & 3.523 & $576,85.5$ \\
\hline 1916 & . & .. $640.14 \mathrm{~s}$ & 67,638 & 4.534 & 712,320 \\
\hline 1917 & . & . . 690,133 & 56,381 & 15,935 & 762,449 \\
\hline
\end{tabular}

Meat supplied by "frigorificos" for home consumption represents approximately 12 per cent. of the total weight produced at such establishments; this is the average percentage over the quinquennial period 1912-1917, but in 1917 there was an increase of $18,163,000$ kilos, and during the first six months of the current year a still further notable increase has taken place.

\section{Exportation.}

The following table shows, in tons, the quantities of dead meat for export produced by "frigorificos" and preserved meat factories :- 


\begin{tabular}{|c|c|c|c|c|c|}
\hline Year. & & Beef. & $\begin{array}{c}\text { Mutton } \\
\text { and Lamb. }\end{array}$ & $\begin{array}{l}\text { Pig } \\
\text { Meat. }\end{array}$ & Totals. \\
\hline 1913 & & 447,674 & 59.291 & - & 506,965 \\
\hline 1914 & . & $4+4,533$ & $6 \times, 5<2$ & 299 & $513,+14$ \\
\hline 191 & $\ldots$ & $450,0.55$ & $45,6 \times 2$ & 24979 & 499,616 \\
\hline 1916 & .. & 544,599 & 62.005 & 2.7203 & $6+9,327$ \\
\hline 1917 & $\ldots$ & 619.698 & $+7,269$ & 14,335 & 681,302 \\
\hline
\end{tabular}

If to these figures we add the live animals exported to adjoining countries during the year 1917 ( 71,355 head of eattle, 69,924 sheep, and 1,239 pigs) we arrive at a total weight of 706,992 tons.

\section{Home Consumption.}

In order to estimate the per capita consumption of meat in the Federal capital, we take as a basis the number of inhabitans: as given in the municipal statisties, and the number and weight of the carcases of meat as reported by the slaughterhouses at Liniers and the "frigorificos." The following is the result, showing the consumption in kilos per inhabitant:-

\begin{tabular}{|c|c|c|c|c|c|c|}
\hline Years. & & Population. & Beef. & $\begin{array}{l}\text { Mutton } \\
\text { \& Lamb. }\end{array}$ & $\begin{array}{c}\text { Pig } \\
\text { Meat. }\end{array}$ & Totals. \\
\hline 1911 & . & $1,360,406$ & 125 & 24 & 7 & 156 \\
\hline 1912 & . & $1.429,042$ & 116 & 17 & 6 & 139 \\
\hline 1913 & $\ldots$ & $1,480,000$ & 106 & 12 & 7 & 125 \\
\hline 1914 & . & $1,594,1 \cap 6$ & 8.5 & 12 & 9 & 106 \\
\hline 1915 & . & . 1.598 .511 & 4.5 & 10 & 10 & 105 \\
\hline 1916 & . & . 1.612 .825 & 74 & 12 & 11 & 97 \\
\hline 1917 & $\ldots$ & . $\quad 1,624,445$ & 76 & 17 & 7 & 100 \\
\hline
\end{tabular}

It will be noted that the consumption of meat has diminished considerably since 1911, but the consumption of 100 kilos per inhabitant may be regarded as very high for a centre of popmlation where there is such a variety of foodstuffs available as in linenes Aires, and during a period when the cost of living has attained a high level hitherto nnknown. It could be deduced from this fact that, in Argentina, meat is, relatively speaking, one of the least expensive articles of food, or that. in spite of everything, the economic level of the "consumer" is, on the whole, a satisfactory one. 


\section{SHEEPBREEDING IN SOUTH AFRICA.}

Despite droughts and the ravages of diseases unknown in Australia, the flocks of Sonth Africa (British) increased from $16,000,000$ in 1904 to $36,000,000$ in 1913 . According to a recent issue of the "Farmers' Weekly" published at Bloemfontein, the estimated clip for the season 1917-18 was 490,000 bales. This estimate is arrived at by taking the average quantity of bales exported from South Africa during the last five years, but owing to the season throughout the Union having been exceptionally good, the clip is likely to exceed 500,000 bales.

The number of bales of last season's wool left in the open market was 478,348 .

The quantity of wool sold on open market and shipped during the period 1st August, 1917, to 31st March, 1918, was as follows :-

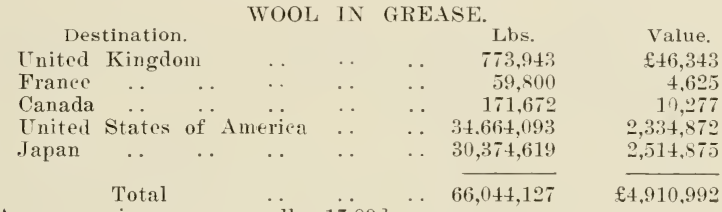

Average price per grease lb., 17.s9t.

\section{Destination.}

United Kingdom

Canada

Unitel States of $A m$ ric

Japan

\section{SCOTRED WOOL}

$$
\text { J }
$$

Total
Average price per seoured lb., $39.93 \mathrm{~d}$.

Total grease and scoured in bales of grease, 265,080 bales.

In wool production, therefore, South Africa has made great strides, and the limit of expansion has not yet been reached. The writer visited the country about seven years ago, and it was comparatively easy to note the scope for development of the wool industry. There was, at that time, a remarkably keen interest in sheep, especially the Merino, and there were many fine stud flocks, and millions of pure wool-bearing sheep. But at the same time one could not look upon the vast extent of $m$ fenced veld without wondering how much fencing wire and subdivision woukl add to the earrying eapacity. 
One could not but notice the numerous flocks of goats, Persian sheep, and bastard sheep without picturing the state of affairs when these nondescript Hocks had been replaced by pure-woolled sheep.

Then the necessity for draining swamps, and providing pure sources of water supply, planting trees for shelter purposes, and grazing flocks within fenced areas, instead of shepherding them all day and kraaling them at night, were being realised by progressive sheepfarmers. Another factor most noticeable was the splendid efforts on the part of the South African Govermment to develop the sheep and wool industry. Experimental farms and colleges were established throughout the Union. The services of capable experts were at the disposal of sheepowners, and behind it all was a magnificent laboratory of research conducted by sir Arnold Theiler, devoted to assisting stockowners in combating the numerous and deadly diseases that affect live stock in South Africa.

All these facts have counted in the development of the sheep and wool industry in South Africa, but another factor might well be mentioned.

After the smoke of the Boer War had cleared away, the African farmer of Boer extraction saw that he was only eighteen or twenty days from the London market. He appreciated the proximity to such a market, and he set out to develop a connection with it. At the time of the Boer War South Africa imported large quantities of meat, chiefly from Australia, and for years after the war these importations continued. The imports of beef and mutton in 1903 (excluding the quantities brought into South Africa by Orange Free State) were valued at $£ 2,885,000$; in 1906 , $£ 757,000^{\circ}$ in 1913 , $£ 105,000$; and in 1915 , $£ 593$, so that the quantities steadily diminished each year, until in 1915 they almost reached vanishing point. On the other hand, exports show a consistent increase from 1914 , when 55 tons, valued at $£ 2,408$, were sent overseas; in $1915,2,274$ tons, value $₫ \$ 6,000$; and in 19165,520 tons, of a total valne of $£ 215,735,2,150$ tons being for eivilian and 3,370 tons for army purposes. The figures of last year are not yet available, but the estimate is 21,000 tons1,000 tons for the Inited Kingdom and 20,000 tons for the Army, all these quantities being exclusive of supplies for ships' stores.

Australia has a particular interest in the development of the sheep and wool industry of South Africa, because South African 
sheepbreeders have for many years been extensive purchasers from Australian stud Merino flocks. As a matter of fact, the leading stud flocks of Australia are just as familiar to South African studbreeders as to breeders here. The merits of rival Australian flocks are just as hotly discussed in South Africa as here, probably more so.

The importations of Australian stud Merinos into South Africa from 1906 until the outbreak of war have been as follows :-

\begin{tabular}{|c|c|c|c|c|c|}
\hline $\begin{array}{l}\text { Year. } \\
1906\end{array}$ & $\ldots$ & & $\ldots$ & $\begin{array}{l}\text { No. of Sheep. } \\
\quad 10,782\end{array}$ & $\begin{array}{c}\text { Value. } \\
£ 29,489\end{array}$ \\
\hline 1907 & $\ldots$ & $\ldots$ & . & 5,380 & 21,495 \\
\hline 1908 & $\ldots$ & $\ldots$ & .. & 6,932 & 15,720 \\
\hline 1909 & . & . . & $\ldots$ & 1,421 & 15,774 \\
\hline 1910 & . & $\cdots$ & . & 2,344 & 20,197 \\
\hline 1911 & . & . & . & 2,440 & 20,470 \\
\hline 1912 & . & . & $\ldots$ & 5,234 & 35,545 \\
\hline 1913 & . & . & .. & 5,349 & 36,165 \\
\hline 1914 & . & $\ldots$ & . & 2,581 & 18,370 \\
\hline
\end{tabular}

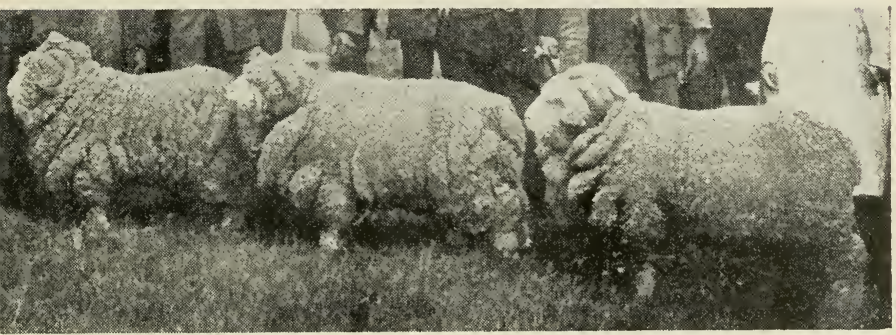

Prizewinners at Witwatersrand Agricultural Show, SOUTH AFRICA.

South African stud breeders have shown great enterprise, and have proved themselves to be equal to their Australian contemporaries, when it comes to backing their fancies with their cash. Many high-priced rams have gone to South Africa. Even this war and the absolute dislocation of shipping between Australia and South Africa has not daunted the spirit of South Africa to progress, for Mr. J. S. Minnaar, of Cape Colony, has just purchased a ram from F. S. Falkiner and Sons, Limited. Wanganella Estate, for 2,000 guineas. This is a plucky purchase in times like these, when shipping is so disorganised.

Anyone who has kept in touch with sheepbreeding in South Africa cannot fail to notice the general improvement in the stud. sheep of that country. 


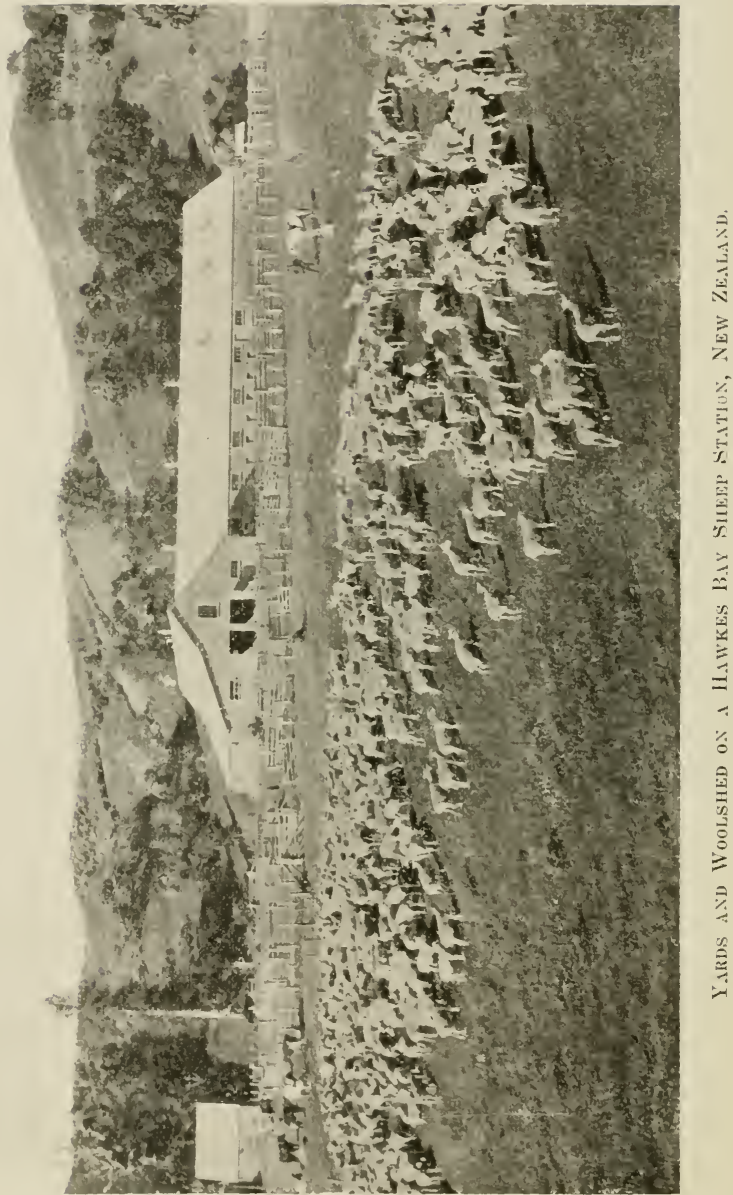




\section{BREEISS OF BEEF CATTLE IN THE UNITED STATES.}

(A series of articles which appeared in The Pastoral Review last year, from their U.S.A. correspondent.)

\section{SHORTHORNS.}

The decrease in the number of beef animals in the United States, with the resulting high prices which have prevailed during recent years, has caused greater interest to be taken in this industry, and many men who have never raised beef eattle in the past are taking $u p$ this line of work.

The breeds of beef eattle in the United states are the shorthorn, Polled Durham, Hereford, Aberdeen-Angus, and Galloway. Each of these breeds has been earefully developed for a long period of year's, with the result that individuals transmit their characters very readily when bred to native or serub eattle.

The shorthorn is the most popular of the beef breeds in tine [nited States, as shown by their numbers and by their general distribution over all parts of the country. They have a great range of adaptability and do well everywhere. The milking qualities, combined with tl e high standard as a beef animal and the gentle disposition, have cansed the Shorthorn cow to be termed "the farmer's cow" in the United States. The merit of the breed has been proved on the ranges of the west, where the bulls have been used for grading up the scrub cattle of the plains. The Shorthorn erosses well with other breeds or with the serub cattle, producing from scrub cows ealves which develop into fairly desirable beef cattle. The grazing ability of the Shorthorn is not so good as that of some of the other breeds, but where grasses are abundant and feeds are plentiful there is no breed which will surpass it for beef production. The large milk flow insure a good calf. Iowever, the cows have been criticised to a certain extent by western ranchmen because the large milk flow causes many of them to lose a teat or a portion of the udder, as the calves camnot always take all of the milk. The sieers sell readily as feeders, and althongh they have not won as readily as the Aberdeen-Angus in the show ring, they produce very highclass beef, with the thick loin and full hindquarter which furnish profitable cuts.

The three important strains of Shorthorn cattle have been the Booth, the liates, and the Scoteh tribes. The Booth and Scotch strains represent the true beef type of Shorthorns, while the 


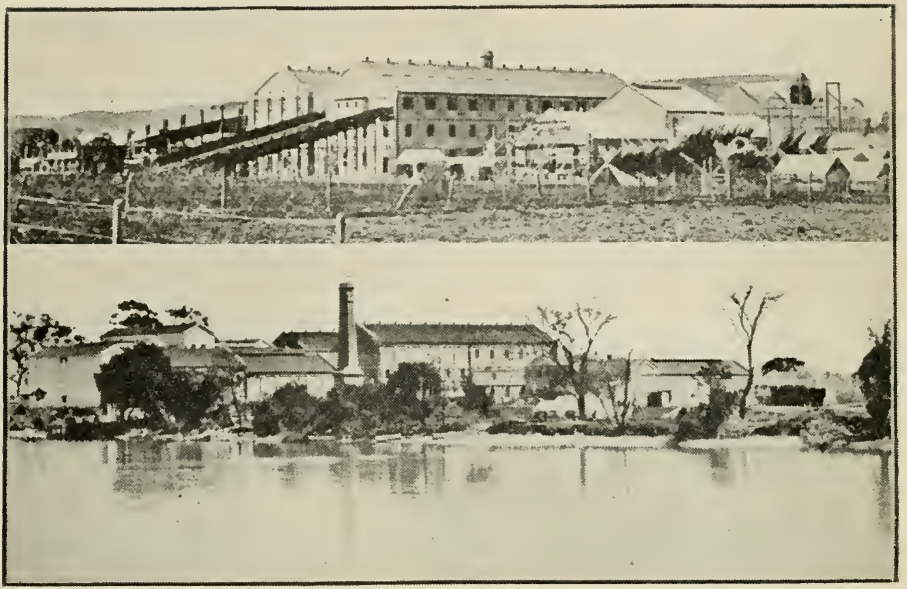

Whakataye Meat Works, New Zealaxd

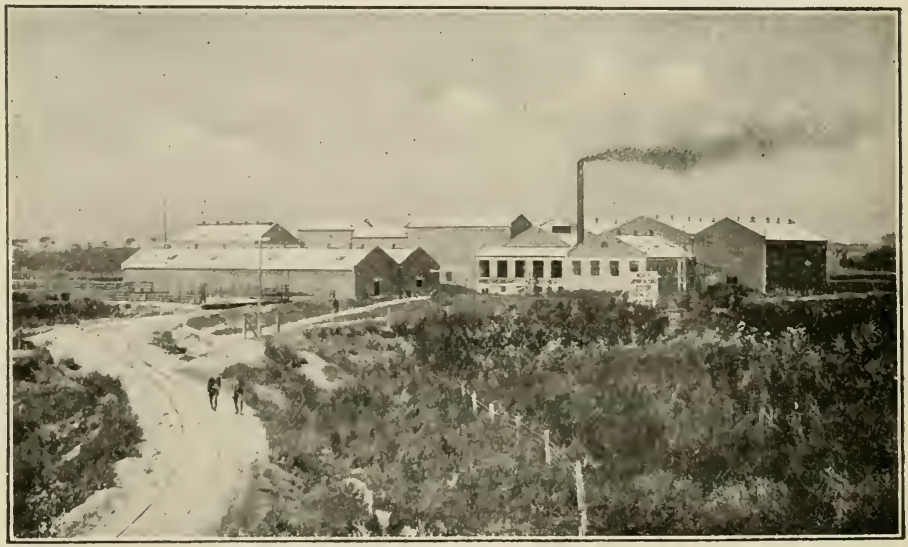

Meat Works at KaIapor, New Zealaxd 
Bates approaches the dual-purpose type. Bulls attain a weight of 1,800 to 2,200 pounds or more, while the mature cows usually weigh from 1,300 to 1,600 pounds when raised under favorable conditions. Greater weight in both cows and bulls is not rare, but extremely heary animals are not especially desired.

MIr. W. F. Ward, Senior Animal Husbandman in Beef Cattle Investigations, U.S.A., in a pamphlet issued to farmers, says:-

"In conformation, the Shorthorn is of the true beef type, being wide, deep, lengthy, and thickly fleshed. The great width of the Shorthorns, combined with their depth, gives them a more rectangular form than any of the other breeds, while the wide variation in the distribution of the breed has caused a slightly greater difference in type to be recognised than in other beef breeds. In the cow the following points should be noted:-The horn is usually small and eurved forward, with the tips pointing inward, upward, or sometimes downward, and they should be of a waxy, yellowish color. The head should be shapely, with great width between the eyes, short from the eyes to the muzzle, which should be large and flesh-coloured, with large nostrils; a black muzzle is objectionable to most breeders. The neck should be short and full, blending well into head and shoulder. The shoulders should be smooth and well covered with flesh, the crops should be full, the heart girth should be large, and the fore flank low. The chest should be wide and deep, with the brisket thick and well to the front. The ribs are usually well spring and the barrel well developed. In good individuals the back is broad and the loin is wide, deep, and thickly fleshed. The hips are wide and should be well covered with flesh; the rump is long, wide, and level, carrying an abundance of flesh. The hindquarter is better developed in the Shorthorn than in any other breed; it is characteristic in that it is almost straight from the root of the tail to the hocks, and is wide and thick, earrying the flesh well down, thus giving a maximum amount of flesh. The flank is low, the udder is usually well developed, extending we!l forward, with prominent milk veins. The teats are of medium size.

"The bull should possess the same desirable features as the female, without her feminine qualities. He should show masculinity by developing a heavier horn, a larger and thicker neck, a heavier bone throughout, and greater depth, thickness, and scale. His horns are straighter and heavier than the cow's, but they should not show coarseness. 


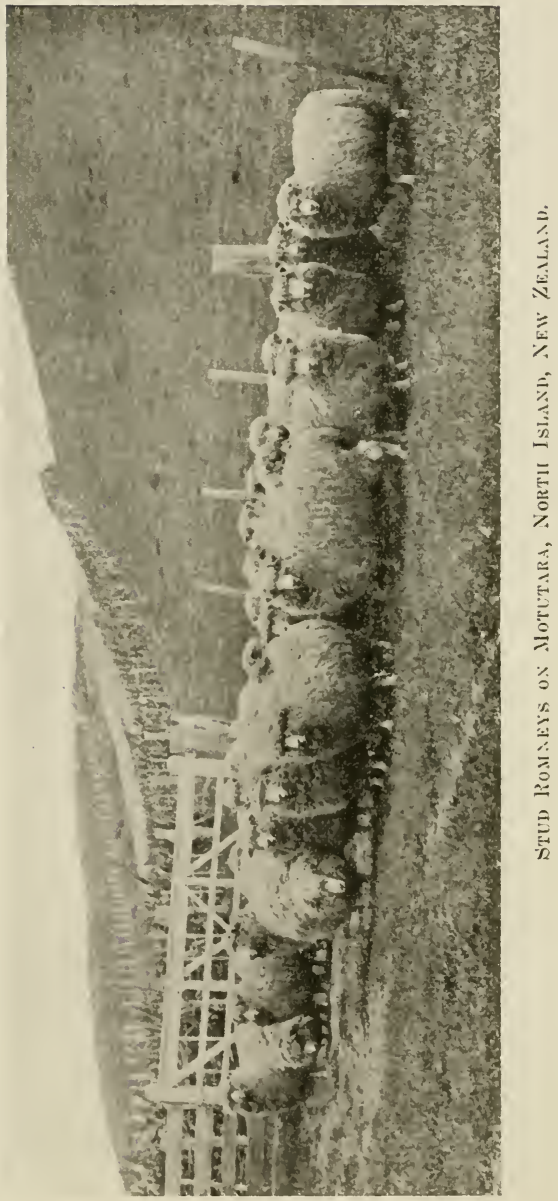


"The Shorthorn has sometimes been criticised because of poor development or lack of fulness in the crops, a high fore flank, and a poorly developed heart girth. They are sometimes rather leggy, although animals of Scotch breeding are nsually thick fleshed and low set. There has been a tendency to patehiness near the root of the tail and to rolls on the sides, but the breed is improving in this respect in that the animals are becoming more smooth.'

The American Shorthorn Breeders' Association considers that the ten bulls which have probably done most for the improvement of Shorthorn cattle as a breed in the last fifteen years are as follows:- Whitehall Sultan 163573, Choice Goods 186802, Cumberland's Last 229822, Avondale 245144, March Knight 188105, Villager 295884, Cumberland 118578, Merry Hampton 132572, Lord Banff 150718, and Whitehall Marshall 20.9776. The most popular families of Shorthorns in the United States at the present time are Angustas, Missies, Victorias, Duchess of Glosters, and Orange Blossoms.

The Polled Durham is a Polled Shorthorn. There are two general divisions of this breed, the "single standard" and the "double standard." The single-standard Polled Durhams were nroduced hy breeding "muley" eows to Shorthorn bulls, selecting the volled offspring and breeding these to other Shorthorn bulls. This grading up was continued until the polled offspring was brought to the fifth cross which contained $96 \frac{7}{5}$ per cent. or more of Shorthorn blood, and which qualified for entry in the Polled Durham herd book. The resulting progeny resembled the Shortherms, but were rather leggy, lacked a thick smooth covering of flesh, and inclined more to the dual-purpose type of animals. These cattle conld be registered in the Polled Durham herd book, but were not eligible for registration in the American Shorthorn herd book.

The double-standard Polled Durhams were secured by using purebred Shorthorn cows that were either natural muley or had undeveloped horns, for breeding to Shorthorn bulls. The doublestandard Polled Durhams are purebred Shorthorns, and ean be registered in either the Shorthorn or the Polled Durham herd books. The double-standard Polled Durhams were bred chiefly from the Gwymne, White Rose, and Young Phyllis families of Shorthorns. 


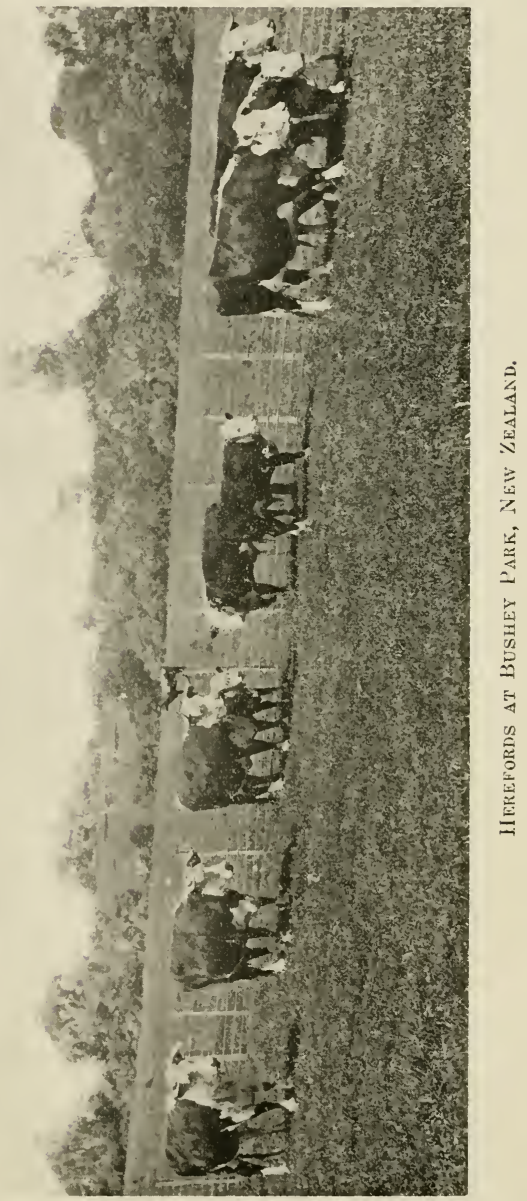


This breed is similar to the Shorthorn in every way except that it is hornless. It is a comparatively new breed of cattle, and has not become so popular as the older breeds, but it is increasing in popularity. They will do well under the same conditions which favour the production of good Shorthorns. Some breeders have developed the dual-purpose qualities in the animals with the result that there is considerable variation in type.

\section{The Hereford.}

The Hereford ranks next to the Shorthorn in numbers in the United States of America. Their popularity is constantly increasing, especially where cattle are raised under range or adverse conditions. As a "rustler" the Hereford is surpassed by no breed of beef cattle, and they have been recognised as responding readily to a favourable environment as well as being able to thrive under adverse conditions where other breeds would not do so well. On scant pastures and on the range where waterholes are far apart the Hereford has shown its merit. The bulls are active, vigorous, prepotent, and very sure breeders.

Formerly, the Hereford was severely criticised because of a light hindquarter, but the breed has improved wonderfully in overcoming this defect during the last two decades. It is now somewhat less rangy, more compact, and heavier fleshed than formerly. The Hereford cows have also been eriticised because of their scanty milk flow, but they usually produce enough to raise a good calf. The Hereford of the States has a better heart girth, stronger constitution. and can withstand adverse conditions better than the Shorthorn. They are early maturing, and fatten readily in the feed lot.

The weight of the Hereford is practically the same as that of the Shorthorn. Mature bulls weigh from 1800 to $2200 \mathrm{lbs}$. or more, while good cows weigh from 1200 to 1600 lbs., although it is not unusual for mature animals of either sex to weigh more than stated.

Mr. W. F. Ward, Senior Animal Husbandman in Beef Cattle Investigations, U.S.A., says :-

"In colour the Hereford is red with white markings. The white markings usually consist of a white face and head, the white extending along the top of the neck and shoulders, a white throat and dewlap, and white on the underline. Fre- 
quently, however, no white is found on the neck or top of shoulders. White is sometimes found on other parts of the body ; and, while it is permissable, it is not desirable. A pure white face is usually preferred, although many purebred animals show spots about the face and especially some red around the eyes. The red colour of the body varies from a light red approaching yellow in colour to a very dark red approaching black. Neither the light-red nor the blackish-red colour is desirable, a rich deep red being the most popular. The hair is usually of medium length with a curly tendency, although short-haired animals are common.

"The general conformation of the Hereford is the same as that of the Shorthorn, except that the rectangular form is not quite so pronounced and the prominent bones are more smoothly covered. The form is low, compact, and blocky, with wellsprung ribs, broad loin, and wide hips, without the prominent hip bones of the Shorthorn, and with a more rounded and bulging quarter, although developed to a lesser degree in this respect than the Aberdeen-Angus. The head is broad and short, with large nostrils, and large muzzle and mouth, which are indications of a good feeder. The horn is longer and somewhat coarser than the Shorthorn, white in colour with waxy tips, and curves outward, upward, and backward, or outward and forward and occasionally they are drooping. The horns of the bull are straighter and heavier, and usually grow outward, frequently growing forward, backward, or downward, but seldom growing mpward. The neck is short, thick, and blends well with the shoulder. Great width, depth, and length of chest and a fulness of the crops give the Herefords their constitution and endurance, which the breeders have been careful to preserve. The loin is full and deep, and the rump and hindquarter are usually well developed, carrying a large amount of flesh. This portion of the body has been greatly improved within recent years, and the tendency to roughness and patchiness has been reduced until the breed now stands out as one showing extreme beef type, with smonthness of form and much quality. For these reasons, combined with their rustling abilities, the Hereford has become the most novular breed for improving range stock. The effects of using Hereford bulls for this purpose has had a great attraction for cattlemen in the south-west, especially in the Panhandle region of Texas."

The Herefords do well in the sonthern States, as the heat there seems to bother them no more than it does in the corn belt. They 
seem to be especially adapted for use on the larger plantations, where animals are not given extremely good care, and where the production of beef alone is desired. Two or three crosses on the native stock of the south produce a good beef animal that matures early and fattens out well. On plantations especially or on farms with only fairly good pastures the Hereford will give better results than the Shorthorn.

The American Hereford Cattle Breeders' Association mentions the following as some of the bulls which have been most influential in improving the Hereford breed in the last fifteen years:- Perfection Fairfax. Beau Donald, Beau Brummel, Corrector, Disturber, Bonnie Brae 8th, Perfection, Mareh On 6th, Prime Lad, and Repeater.

\section{Poljled Herefords.}

The Polled Hereford is a new breed developed by selecting and breeding Herefords which showed polled characteristies. The donble-standard Polled Herefords are purebred Herefords which are hornless and are eligible to registry in either the American Hereford herd book or the American Polled Hereford record. They differ in no way from the Hereford excent that they have no horns. The polled feature has been well fixed, and the bulls when mated with native cattle sire few calves laving either long scurs or horns.

\section{Aberdeen-Angus.}

Aberdeen-Angus cattle are solid black in colour, and have no horns. These characteristics are so strongly developed that a bull, when bred to horned cows of varions colours, will nsually produce ealves of which 85 per cent. or more are black in colour and hornless. Occasionally a red animal is found in this breed, but the colour is not popular among breeders. While the Aberdeen-Angus is an old breed, it is only within recent years that it has been so popular in the United States. While they are good rustlers, they have never been as popular on the ranges of the west as either the Hereford or the Shorthorn. They stand next to the Hereford and above the Shorthorn as graziers on scanty pastures. This breed is extremely valuable for grading un native cattle, but they have been eriticised to a certain extent by rangemen because they do not get a greater percentage of calves. This has usually been true where they have been in 

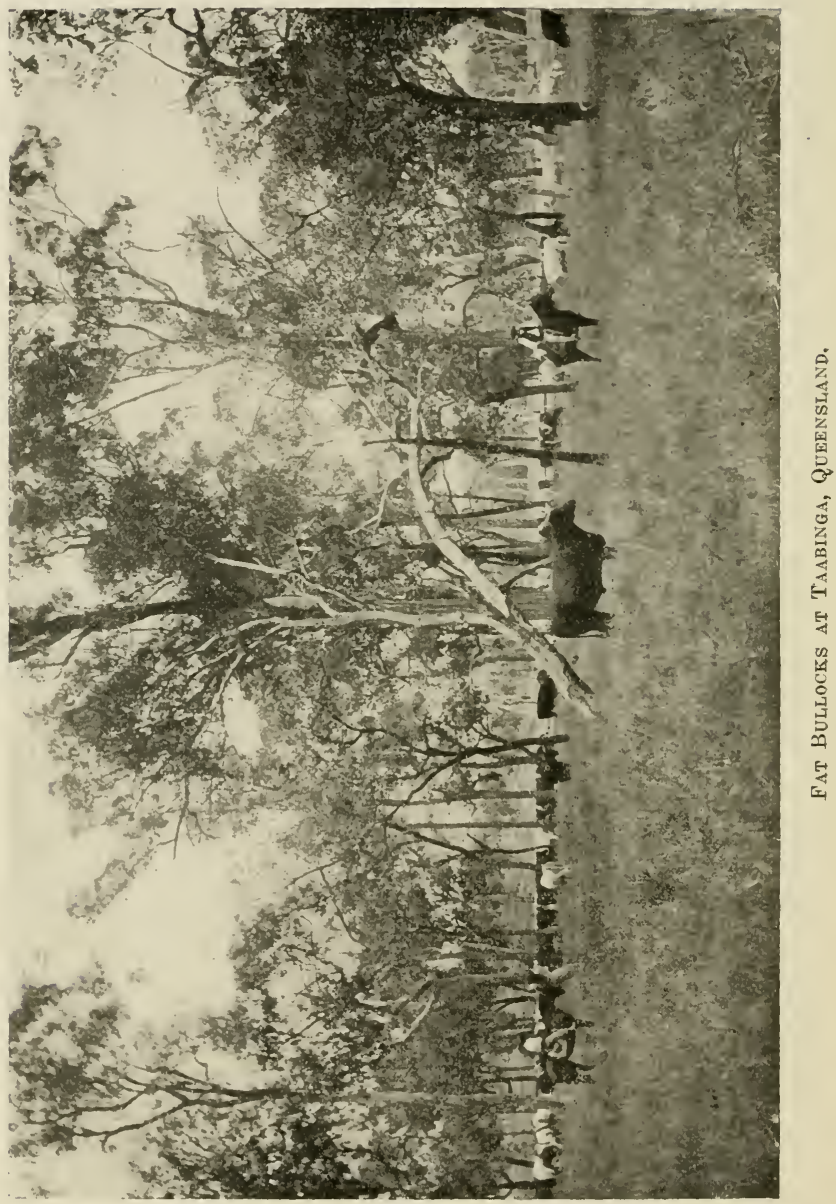
a herd with horned bulls. If all the bulls were either polled or dehorned there would doubtless be less ground for this claim. The milking qualities of the eows are only fair; they give more milk than the Hereford, but not as much as the Shorthorn. A sufficient quantity of milk is produced to raise a good ealf.

This breed is very early maturing, and has a tendency to fatten well at any age, hence their popularity for producing baby beef. In general form they are different from the Shorthorn and Hereford. The body is more cylindrical in shape, and they are smoother throughout than either of the breeds named. The Angus responds quickly to good treatment, and, becanse of their readiness to fatten, early maturity, exceptional vigour, high quality, general smoothness and uniformity, and the high percentage of valuable meat produced, it is the most popular of all beef breeds among eattle feeders. They usually dress out a higher percentage of marketable meat than any other breed, and their merit has been shown by the repeated winnings they have nade in the show-ring and on the block.

They stand either heat or cold well, and are popular in the sonth as well as in the corn belt. Because of their reputation for finishing smoothly and killing out well they are very popular in the corn belt and neighbouring States, where much feeding is done. They are becoming more popular in the south, and rank next to the Hereford and above the Shorthorn in their general adaptability to average sonthern conditions.

Mr. W. F. Ward says:- "The head of the Angus shows a sharp tapered poll, great breadth between the eyes, a prominent forehead, prominent eyes, a nose of medium length, a large month and muzzle, and large nostrils. They are more restless or nervous than the Shorthorn. The neck is short, full, and has a well-developed crest in the bull, but it does not always blend smoothly with the shoulders, which are sometimes a little prominent. The chest shows great depth, width, and length. The body is cylindrical in shape, and does not show the squareness or blockiness of the Shorthorn and the Hereford, but is noted for its compactness and good covering of flesh. The ribs are well sprung, curved, and long, giving the cylindrical form to the body. The loin and rump are well fleshed and deeply covered, but entirely different in shape from the Shorthorn, as the great width and squareness are absent. The deep covering of flesh of the rump, the smallness of bone, and the deep rounding, bulging hindquarter gives a maximum amount of meat. Note the dif- 
ference in the hindquarter of the Angus and the Shorthorn. The latter is broad and straight from pin bones to the hock, while the Aberdeen-Angus has less breadth and a very rounded bulging quarter with a deep twist. The Angus is not so low in the flank as the Shorthorn, and some individuals are light in the hindquarter.

"The quality of the animal is unsurpassed, as shown by the soft, pliable, mellow skin, and fine hair. The meat is fine-grained and of the highest quality. The constitution and vigour of this breed as indieated by well-developed chest and good heart girth are worthy of mention. For grading up native stock and for crossing, they hold an enviable record.",

\section{Time Galloway.}

The Galloway is one of the oldest breeds of eattle. They are polled, solid black in colour, though oceasionally some brown is shown, and have a long, curly, silky coat. This breed is very prepotent, and transmits the black colour and polled characteristies readily to offispring from cows of any colour. As high as 90 per cent. of the calves from various-coloured cows are black, and from 95 to 99 per cent. of the offspring from horned eows are polled. This breed is slow maturing when compared to the Aberdeen-Angus or the Hereford. In size they are smaller than any of the other beef breeds. Mature bulls usually weigh from 1700 to 1900 lbs., while the mature cows weigh from 1000 to $1300 \mathrm{lbs}$. each.

These cattle are exceedingly good rustlers, not being excelled by any other beef breed in this respect, and their long silky coat of hair enables them to stand 'severe weather with little discomfort. For these reasons they have proved to be very valuable on some of the ranges of the north-west and of Canada. They do not respond so readily to good treatment and to plenty of feed as do the other breeds, and have therefore not become popular in the corn-belt States.

In form they are low set and deep, but are proportionately longer than the Aberdeen-Angus and flatter of rib. The head is somewhat similar to that of the Angus, except that the poll is not as sharp. The head is covered with long wary hair and the ear is set farther back from the forehead. The body is long and of medium depth. The rump is long and well filled, althongh the tail head is usually set rather high. The hindquarter is 
usually good, being full, similar to that of the Angus. The bone is fine, the skin mellow, the hair soft and silky, and the grain of the meat is fine and high in quality. Little attention has been devoted to the milking qualities of Galloway cows, but they give enough milk to raise a good calf. The milk is regarded as ranking high in butter-fat, and having good quality. The Galloways have commanded especial attention because of their prepotency and the uniformity of the offspring when the bulls are used for grading up or for crossing.

This breed will probably never be very popular in the United States except in the north-west, where climatic conditions are severe and the range grasses are often scant. In that section, however, the bulls could be used advantageonsly for grading up native stock.

\section{DUAL PURPOSE BREEDS.}

The dual purpose cattle have been bred to produce femeles which would yield a good quantity of milk and produce offspring which would be desirable for beef. As the type of animal necessary for the production of large yields of milk is entirely different from that of the beef animals, it has been impossible to produce a breed which would combine these functions and be of superior merit for both purposes. The dual-purpose animal may, however, be a desirable milker and at the same time produce calves which make good, though not superior, beef animals. As there has been a constant tendency for some breeders to incline more to the dairy type of animals, while others prefer to develop the beef tendencies, there has been, and probably always will be, a wide variation in the type of dual-purpose animals. They are not so uniform in conformation as either the strictly beef or dairy breeds. Most breeders prefer to use cows which approach the dairy type nearer than the beef type and to use a bull of the beef type that had a dam with a good milk record. The offspring of such cattle necessarily cannot be of as uniform type as the breeds which have but one function to perform.

The dual-purpose cattle are popular with the small farmer, who keeps but a few cattle, and must depend upon them to produce all the milk and butter needed for the family and at the same time raise calves or steers which will sell readily for slaughter purposes. They have not been popular with the ranchman or farmer who raises large numbers of cattle. 


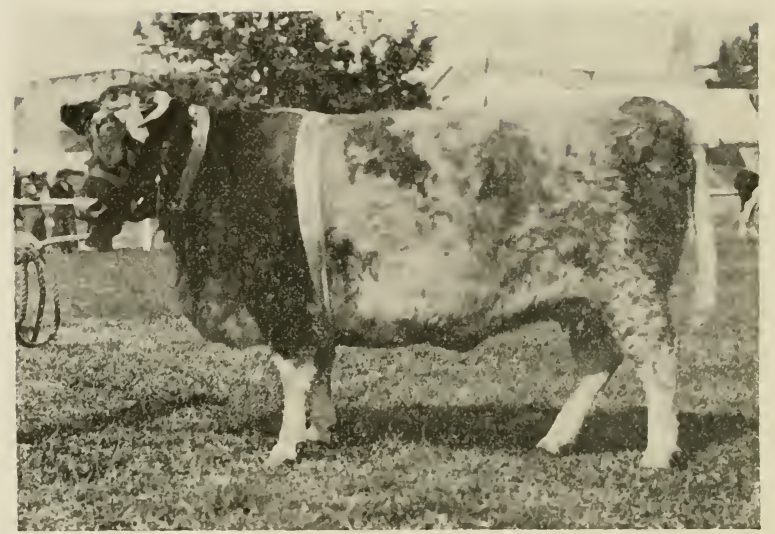

Champion Shorthorn Cow, Cornflower 2nd, Brisbane Sноw, Q., 1918.

Exhibited by the Lomax Pastoral Co.

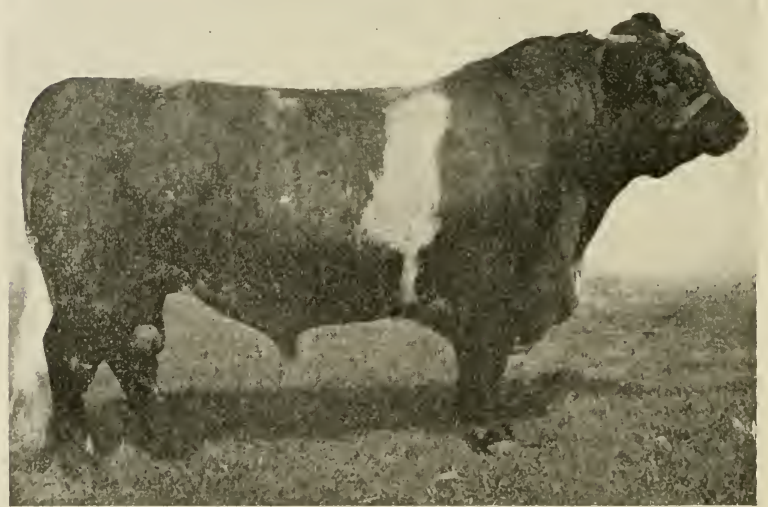

Champion Shorthorn Bull, Grand Duke of Clifton, Brisbane SHow, Q., 1918.

Exhibited by the Lomax Pastoral Co. 
The principal dual-purpose breeds in the United States are certain types of the Shorthorn, together with the Red Polls and Devons.

\section{SHORTHORNS.}

The dual-purpose Shorthorn is more popular than any of the other dual-purpose breeds. They respond readily to good treatment, and have become exceedingly popular with the small farmer. Formerly these cattle were almost entirely of the Bates strain, but at the present time many of them contain considerable Scotch blood. As a breed they are the same as the beef-bred Shorthorms, except that the beefy tendeney is not as strongly emphasised. The milking qualities have been developed, and the cows have a conformation approaching the regular dual-purpose form, being longer of limb, higher in flank, larger in barrel and thinner in hams than the beef Shorthorns. The bulls approach the beef type more than the cows, but are lighter in the hindquarter and a little higher in flank and not so heavily fleshed as the strictly beef type. The udder extends high up in the back and well forward, the milk veins are usually very prominent, and the teats are medium to large in size and are well set. Calves from the cows by a well-fleshed bull usually grow and fatten well and make a good quality of beef.

\section{Red Polls.}

The Red Polled cattle originated in England, and were introduced into this eountry in 1873 , but few importations were made until about 1885. Since that time many have been imported. This is strictly a dual-purpose breed, and approaches the ideal of the dual-purpose type. In size they are smaller than the beef breeds, and have not the thick eovering of flesh. Mature bulls weigh from 1700 to 2100 lbs. or more, and the cows from 1100 to $1350 \mathrm{lbs}$. or more. Occasionally very heavy individuals are found, but these are the exception and not the rule.

The cattle of this breed are fair grazers, ranking with or slightly ahead of the Shorthorns but not equal to the Devon or Hereford. They are very prepotent and give uniformity in off. spring when bred to native cows. Like all dual-purpose breeds, it has been hard to fix or to hold a uniform type, as many breeders incline to beef production, while others try to develop the milking qualities to the detriment of the beef form. 
This breed has long been celebrated for its early maturity, easy fleshing qualities, and for a fair to good milk flow. The steer's have attracted attention and sold for high prices on English markets for years, and have made very creditable showings in this country. They make good daily gains and lay on flesh evenly. They are usually rather leggy, and lack the heary fleshing qualities of the beef breeds. The hindquarters are less well developed, with a tendeney toward a rather thin thigh and a high flank and twist.

The milking qualities of the breed are fair. Many of the cows average over $5000 \mathrm{lbs}$. of milk a year. The cows flesh up readily when dry.

In conformation these cattle resemble the Deron. The head is lean, medium in length, with a well-defined poll, covered with a nice tuft of hair of medium length. The neck is longer and thinner than in the beef breeds and does not blend with the shoulders so nicely. The chest is usually well developed and the ribs well sprung, though lacking in a thick covering of flesh. The barrel is developed to a greater extent than with the beef breeds, and the loin and hindquarter are lighter fleshed. The bone is of medium size. The skin is thin, soft, and pliable, and the hair is short and fine, showing quality. The colour ranges from light red to dark red, but a deep, rich red is preferred throughout, althongh a little white on the udder or under line and a white brush are permissible. The udder is well developed in the back, but does not come forward well; it is "chopped off," and the tendency is to develop large teats. The milk veins are prominent and of fair size.

The Red Polls are more nervous than the Shorthorn, but less so than the Aberdeen-Angus. As this is a comparatively young breed, they are not so popular as the older breeds. As dualpurpose cattle they are hard to excel.

\section{Devoss.}

Devons, one of the oldest breeds of cattle, were introduced into the United States at an early date, and became popular in New England and in parts of Virginia nearly a century ago. The cows were good milkers, and the stecr's were used as work oxen or for beef, and filled either place admirably. They are exceedingly good rustlers, are vigorous, hardy, withstand both heat and cold well, and are very prepotent. For these reasons 
they were popular with the people of New England. They ars slower of growth than any of the beef breeds except the Galloway. Their endurance, intelligence, and their gameness have made them popular as work oxen wherever they have been tried -no breed excels them in this respect.

In size they are somewhat smaller than the Red Polled, mature bulls weighing from 1500 to 2000 , and cows from 1100 to 140 n pounds or more. They are solid red in colour, white being permitted only on the udder, or near the scrotum of the male, and on the switch of the tail. The shade of red varies, but a rich bright red is preferred. In conformation the Devons incline more to the beef type than to the dual-purpose type. They are close coupled, very compact, smooth, and rank high in quality and style. They have small bone, which is hard and compact, giving a slender, fine leg.

The head is lean, ciean eut, of medinm length, and surmounted by rather long white or waxy horns, which eurve upward, forward, ontward, and backward in the eow, and are almost straight in the bull. The horns of the steers are large, long, and often widespread, usually being very white or waxy, with dark tips. The neck is medium in length, smooth, and blends nicely with the shoulder. The body is compact, fairly well covered with fiesh, has well-sprung, deep ribs, and is usually low set. The chest, back, loin, and hindquarter are usually well developed, though the flank and twist are usually somewhat higher than in the beef breeds. The cows are fair to good milkers giving rich milk, and always provide an abundance to bring forward a good calf. The steers fatten somewhat slower than the beef breeds, but produce meat fine in texture and of good quality. The breed camnot be surpassed as good feeders, but they are usually slower in growth than the beef breeds, and this alone can account for the fact that they have never become popular throughout the country. In New England, in parts of the south, and in a few other States the Devon has proved profitable, especially on lands where the grazing was ratlier seant or of poor quality. They are prepotent: good calves are produced when good bulls are mated with common cows, and such calves usually make fair milkers.

\section{Brahman or "TNDin" CatTle.}

Under the names of Brahman, "Indian," or Zebu cattle are classified a number of different strains of eattle of the species: 


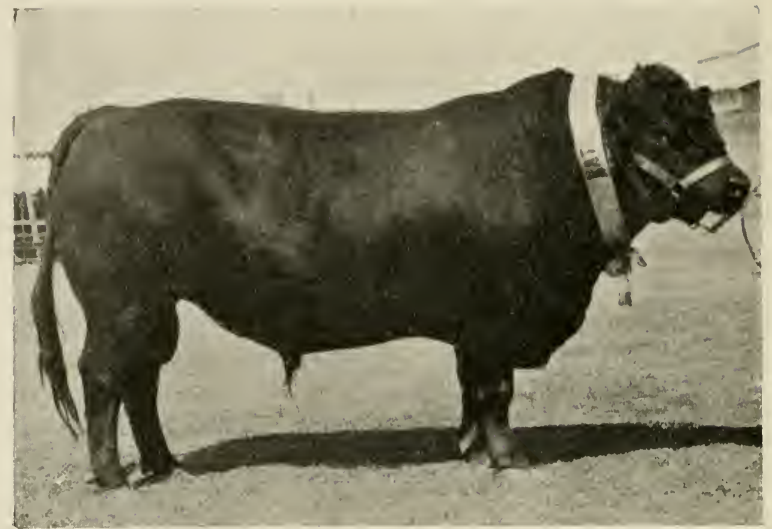

Champion Aberdeen Angus Bull, "Heather Duke," at Brisbane Show, Q., 1918.

Exhibited by Mr. J. McIntosh.

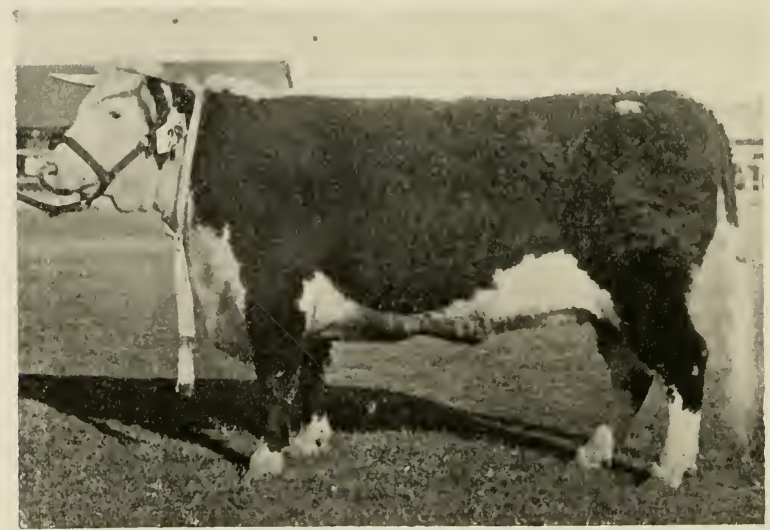

C'Hampion Hereford Cow, Jean, Brisbane Show, Q., 1918. Exhibited by Mr. J. Sparkes. 
Bos indieus. Some of these strains vary so in type, colour, size, and habitat that they are classified as separate breeds. The most important breeds of these eattle are the Krishna Valley and Hissar breeds. These eattle are classed as dual-purpose animals, as many of the females give a good quantity of milk. They are used quite generally in India as milch cows, and are more satisfactory than any other breed of eattle under the severe conditions of drought, heat, insect enemies, ete.

As these cattle have been raised for more than three thousand years in a hot climate, they are only suitable for warm country. Although they are of a different species from our common breeds of cattle, they cross readily with them. The females of this breed carry their calves somewhat longer than other cattle, the period of gestation being about three hundred days.

The oil secreted by the sebaceous glands of the skin is of a peculiar odour and gives the skin a soft, oily feeling. This peculiarity, combined with the scant covering of hair and the extremely tough hide, affords these animals considerable protection from ticks, mosquitoes, etc. Cattle ticks do not bother the purebred cattle at all, and few of the half-breeds become infested to any appreciable extent.

These cattle stand the heat well, and have great endurance, moving readily in a fast walk or trot. They make the best of work steers if handled constantly by one driver, but they have a nervous disposition, and give considerable trouble where the drivers are frequently changed. They are more nervous than any of our breeds of eattle. When raised in small herds and handled constantly they are quite docile, but if handled under range conditions they become very wild, and stampede or fight readily. The quality of the beef from these animals or from grade Brahmans is slightly inferior to that of either the beef breeds or the dual-purpose cattle, but they dress out a high percentage of meat.

In size the bulls range from 1500 to 1800 pounds, and many of them attain a height of $6 \mathrm{ft}$., while the cows usually weigh from 1100 to 1400 pounds. The various strains of these cattle have different colours, although each strain has a fixed colour. The colours are pure white or a creamy white, silvery grey, red, and dark brown approaching black. The silver grey, with dark fawn on shoulders and neck, and the creamy white are the most popular colours. Many of the animals have brindle stripes on the body. 
The chief eharacteristies of the breed are the large hump on the withers, the large loose folds of skin forming the dewlap and the navel, and the long, drooping, pendulous ears. The head is also charaeteristic of this breed, as it is long, with a forehead which recedes from the eyes to the horns, while the bones forming the brow are prominent. The head tapers gradually from the eyes to the nostrils, the horus are dark, short, straight, heavy at the base, and point upward and backward. The ears are very long, drooping, and are thin and oily, frequently being almost devoid of hair. The eye is mild and sleepy, but changes quickly when the animal is aroused. The neck is of medium length and has heavy folds of skin forming an overdeveloped dewlap with fulness at the throttle. The body is deep but rather narrow, the hips are long, sloping, and narrow, and the rump often droops toward the tail. The legs are long, tapering, and show a strong bone free from eoarseness. A very heavy sheath is developed, and in old bulls often hangs $9 \mathrm{in}$. or more below the belly. The hump is large in the males, attaining a height of 12 to 16 inches, but is not so well developed in the females. The half-bred males may have a moderately developed hump, but the half-bred females have none. Animals which contain as little as one-sixteenth Brahman blood usually show some Brahman eharacteristies, espeeially in the shape of the head and the loose folds of skin forming dewlap and navel.

\section{DIPPING CATTLE.}

\section{The Benefit and Practicability of Dipping Cattle on Large Holdings.}

Mr. E. E. D. White, Bluff Downs, North Queensland, writes me as follows:-

"It is over twenty years since ticks first made their appearance in the Burdekin waters, when we lost up to 60 per cent. of our eattle from tick fever. Those that survived and their progeny beeame immune to the fever, and this immunity remains with the eattle on all comntry that continues to be badly infested with ticks. So there are practically no losses from fever now. But the extent of the loss we sustain annually through tiek worry is not generally realised. Although most eattle stations now have dips, with very few exceptions, no systematie and methodical attempts have been made to deal effectively with this pest. 
“After ten years' trial here we can emphatically say that in badly-infested areas no investment offers such a reliable and quick returu as money spent on dips and dipping.

"To gange in some degree the extent of the loss we are sustaining compare the number of cattle carried on these runs before and after the coming of the tick. The average is abont half now to that of formerly. Convert that into terms of money to realise the loss to the community and State.

"It is impracticable at the present time to talk of eradication, because of the impossibility of getting financial aid from the State and the high cost of fencing. But the Americans have proved it possible by clearing 475,000 square miles between 1906 , when the work was first undertaken there seriously, up to March 1916. This task must be faced by us later, and because the conditions we will have to work under may make this harder, it eannot be shelved indefinitely on that score. However, what concerns us vitally in the meantime is the necessity of suppressing the ticks and doing away with much of the poverty and mortality to stock now being caused by them. To undertake this work each one making the attempt will very soon have his own experience to guide him, but a few suggestions may not come amiss to those about to start.

"First, put in a good wide dip $6 \mathrm{ft}$. across at water line. This reduces all risks of eattle injuring each other to a minimum, and has every advantage over the narrow dip when working big mobs of eattle. With a good incline and big wide steps on the walk out, the weakest eattle ean be dipped with little risk. The draining yard should be long, and from $8 \mathrm{ft}$. to $12 \mathrm{ft}$. wide. The cattle walk to the far end, and stand quietly without horning and knocking each other about. Dips should be arranged in such positions on the run so the cattle will not be driven more than 7 or 8 miles.

"The number of eattle that can be worked through one dip depends entirely on the carrying capacity of any particular area. But on the tableland, so far, we have found about 2,000 the limit without having to drive too far. How often eattle should be dipped depends upon the nature of the country, for whereas on certain rums on the Upper and Lower Burdekin it is found necessary to dip every three weeks through the year, there are other places within the tick-infested area that find an occasional dipping suffices. In this men must be guided by their 


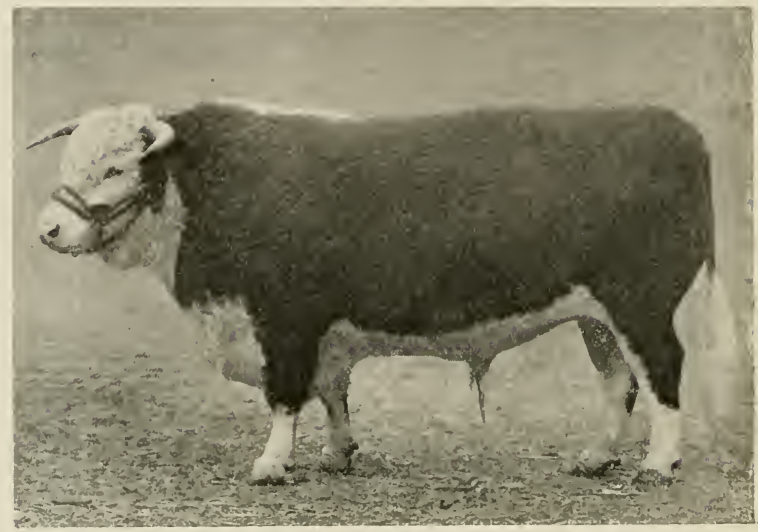

Reserve Champion Hereford Bull, "Sir Hamilton," Brisbane SHow, Q., 1918.

Exhibited by Mrs. Lumley Hill.

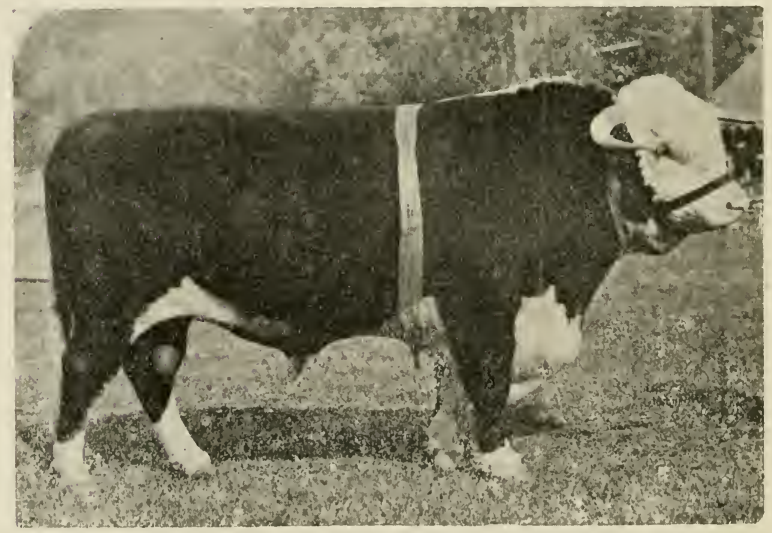

Champion Hereford Bull, Magnitude (imp.), Brisbane Sirow, Q., 1918. Exhibited by Messrs. Tindal \& Sion. 
own experience. It is a bad policy to wait until the hair is coming off the cattle. Taking this tableland country we find that after a good burning in the spring and rain following in November and December, the ticks are not much in evidence until the following April. It is not possible to dip regularly during the first three months owing to wet weather, but by April the wet season is usually over. This is the time, and from this on to July one can get good results from dipping. This is the very best time to work stock. The grass is good, everything strong, and the weather cool, and the ticks if unchecked are increasing at a great rate. Don't delay until the country is infested; catch them early while the cattle are strong and healthy, and keep the ticks off and the condition on, and give the breeders a chance to weather a severe winter and dry spring. One dipping then is worth more than four in Angust.

"It is often contended that the losses from dipping weak cattle outweigh any gain. Our experience is quite the reverse. We never stopped dipping all through the 1915 drought, and not ten head stopped in the dip. Each dipping gave them a new lease of life, and we saved most of our breeders by it. Others say it is impossible to dip bullocks while fattening. This is wrong. It not only quietens them, and makes them better to drove, but improves their condition and weight. It is not advisable to put cattle on the road immediately after dipping. They should have at least five days' rest in paddocks. Calves ean be dipped from two weeks of age upwards, but the strength of the dip should be less than the accepted standard. Although almost as much benefit can be derived from dipping on big unfenced runs, better results can naturally be obtained where they are subdivided and not more than 1,000 to 1,500 cattle carried in one paddock. This allows the mustering to be done cleanly and systematically. Where eight stockmen used to look after up to 20,000 clean cattle formerly with fair success, it requires treble the hands, at least, to work and dip effectively that number now. Six men ean attend to 3,000 or 4,000 head. Bullocks require about one-third the attention that breeders do. Where no shoeing of horses is done (which involves a big addition to the work on basalt country) this estimate may not apply.

"Now to meet this big increase in working stock under these conditions-allow we save half the cows that die on the average annually from tick worry. This mortality on the tableland is about $\delta 0$ per cent. of the total females branded each year. The 
balance of 20 per cent. (over the actual number if returns were fortheoming) are those eows sold and killed for beef. On a holding branding 2,000 ealves, instead of turning off 200 eows, which very few do in that proportion they should be marketing at least 500 . These extra 300 eows alone at present values would more than compensate for all extra expenditure incurred. Then take into consideration the holding would carry 50 per cent. more stock with all the additional returns for an increased turn off and better class of bullocks."

\section{CATTLE TICK ERADICATION.}

Of course, there are many methods of tick eradication, used either separately or conjointly, the more important and more generally known, however, being dipping, spraying, inoculation, burning the pasture, and starvation methods, the soiling method, the feedlot method, and the pasture rotation method. These are some of the means at the disposal of the cattle owners, and a few words about each should be of interest and ralue.



Ox Skin, showing Gross Tick Infestation. 
Before dealing with the remedies, however, the dangers of the tick evil itself cannot be too strongly impressed. About four years ago the Bureau of Animal Industry (U.S.A.) issued a circular to stockowners with a view to securing direct evidence regarding the benefits derived from the tick eradication work carried on within the quarantine area. This circular took the form of a number of questions which are given herewith with some of the summarised answers. They afford most impressive evidence, not only of enormous losses prevented, but also of immense gains obtained by the dipping of animals for ridding them of ticks.

In reply to the question, "What were the approximate annual losses of cattle from tick fever in your county, from 1900 to 1909 inclusive?" the summarised answer was: "15.3 per cent.," and this was followed by the query: "What has been the annual loss of eattle from tick fever since tick eradication started?" The answer-1.3 per cent.-compared with the 15.3 per cent. in reply to the first question, shows that tick eradication work resulted in the losses being reduced almost to vanishing point. The next two questions brought forth the information that whereas from 1900 to 1909 inclusive the average value of three-year-cld steers was 16.15 dollars (67s. 3d.), in 1912, i.e., between two and three years after the commencement of tick eradication work, it amounted to 25.28 dollars (105s. 4 d.). In comparing these two amounts, however, allowance has to be made for the general advance in the price of cattle, but even when this is done, the price shows an appreciation of 40 per cent., which ean be properly eredited to the absence of the tick.

Two more questions and their replies may be quoted:- "Is there any difference in the average weight of the eattle now and before tick eradication was started? How much?" Answer: "Yes. Average inerease 22 per cent. Average weight increase, 116 lbs." Taking the value of the animals at $1_{4}^{3} \mathrm{~d}$. per lb. (the average for three-year-old steers in U.S.A.), the average gain thus works out at about $16 \mathrm{~s}$. $8 \mathrm{~d}$. per head. Finally, the reply to the question: "Is there any improvement in the grades of cattle in your country since the work of tick eradication was started?" was practically a unanimous affirmative. These reports indicate very striking results, and the comment of a correspondent of the U.S. Department of Agriculture is worth quoting: "With the prospect of tick eradication, the raising of cattle is springing into life. In years gone by, with the tick depopu- 


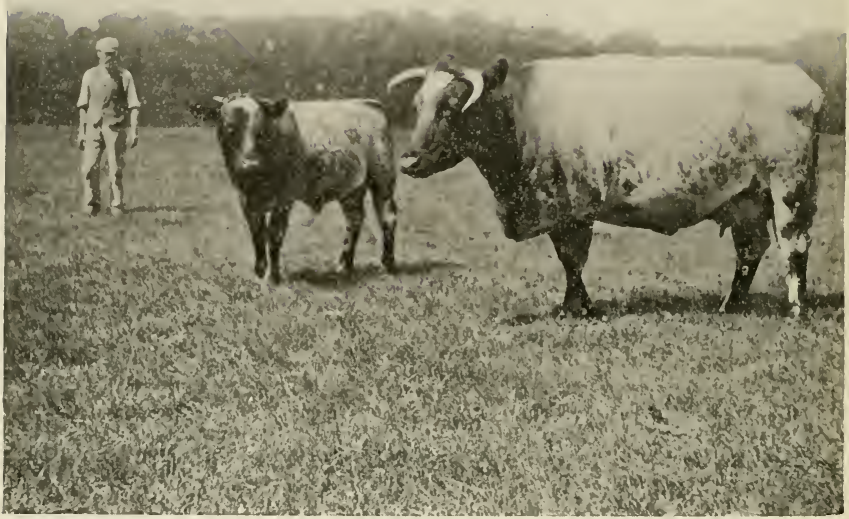

Shorthorn Cow and Bull Calf, Royal Farm, Windsor, England.

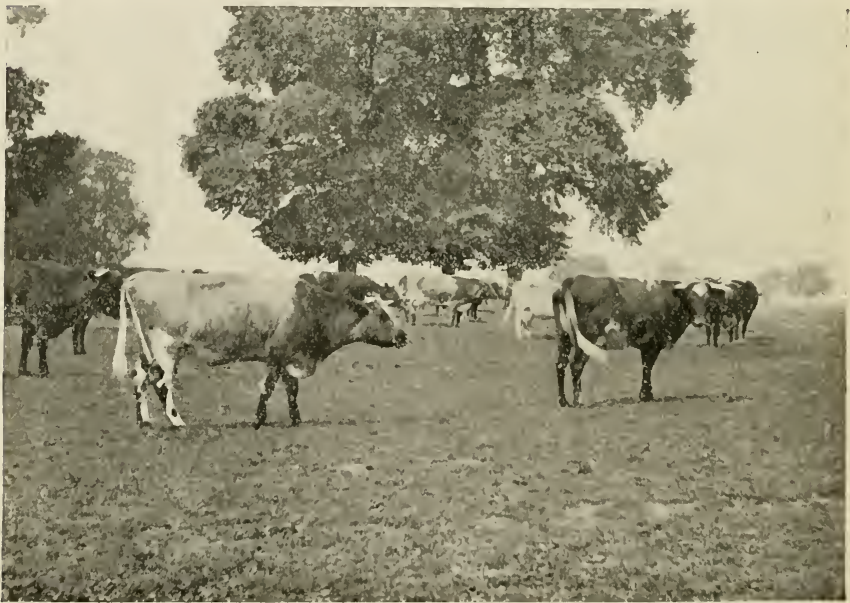

Group of Shorthorn Cows at the Royal F'arm, Windsor, England. 
lating bunches of cattle, there was no money to be made in raising eattle. With the present outlook, men are fencing their lands, and there is sharp competition for every heifer or cow that can be bought. If our authorities will pass a tick law, and see that it is rigidly enforced, we can clear out the ticks in twelve months."

To return to the remedies, dipping is undoubtedly the best method of eradication, provided an efficient dip be used.

Dr. Theiler (South Africa) has stated that the eradication of ticks by starvation "must undoubtedly lead to success in every case where we are able to keep the place, for a sufficient length of time, free from such animals as act as hosts," and that a period of fourteen months would be a safe one to adopt in attempting the eradication of the red, brown, and Bont ticks in South Africa by the starvation method. Careful experiments made at Gonubie Park, Cape Provinee, showed, however, that a fenced-in area of 160 acres, from which all stock had been exeluded for twenty-one months, at the end of that period was still infested with a considerable number of ticks, and no doubt would have remained so indefinitely, owing to the insufficient barrier presented to the ticks by the fencing, and to the impossibility of excluding wild game. The conclusions drawn from these experiments, which included also grass burning, are that the starvation method reduces the number of ticks, and if combined with burning, still further reduces it, but that the method fails to eradicate the ticks, and is inferior to a system of dipping at regular intervals with an efficient dip. Burning doubtless destroys a number of ticks if it is done when they are on the top of the grass, but pasturage is usually such a searee and valuable commodity in this country that burning it is rather too drastic a remedy. Also in regard to the starvation method it must be remembered that there are practical difficulties in the way of enclosing large areas so as to prevent ground game or birds gaining access to it, and bringing in ticks, besides acting as hosts to the ticks already on the ground.

With dipping and starvation combined, the ticks which get on the eattle are being killed off, and simultaneously those ticks which do not find a host are dying of starvation. Also, if a suitable dip be chosen, the ticks which get on immediately after dipping die. In other words, dipping means quick destruction of a certain proportion of the ticks, combined with the slower process of starvation of the remainder. 
In the United States, where Texas fever, or redwater, is the only tiek-borne eattle disease that troubles the stoek farmer, the starvation method is said to have been praetised with success.

The Soiling Method.--This is based upon the following data:The time required for the female tiek to lay eggs and the latter to hatch-i.e., the time spent on the ground-is rarely less than three weeks, and the time required by the seed tieks to mature on the eattle is from twenty to forty-five days.
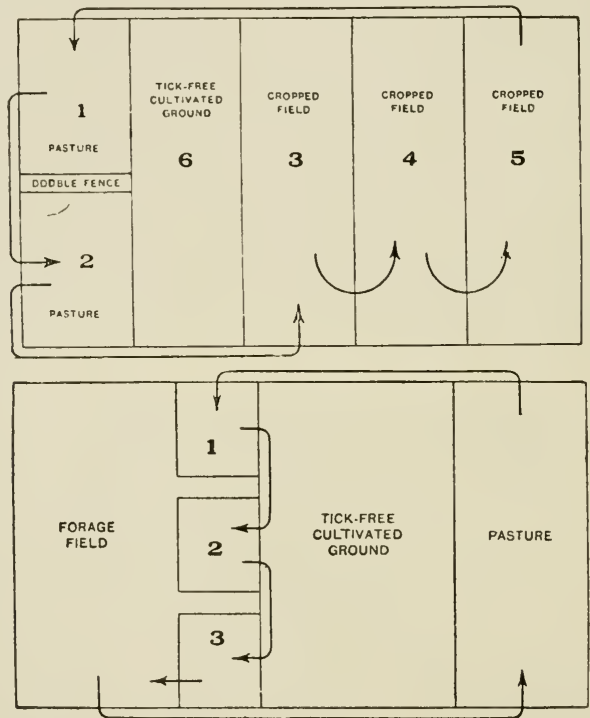

When the tick-infested cattle are to be eleaned it is recommended that they be kept in a small tiek-free enclosure for three weeks, when many of the tieks will have fallen off. They should then be removed to another similar enelosure for another three weeks. After this, they should be examined, and, if found free from ticks, they may be put on non-infested pasture at once. If, however, any ticks are observed, the eattle should be placed in a third enclosure for another two weeks.

By this time the youngest tieks that were on the eattle at the start will have matured and dropped off, and, as the animals are 
removed from each pen before they could have become reinfested by the seed ticks hatched from the eggs of the females that fell off, they are tick-free. It is clear that the enclosures cannot be used repeatedly for the purpose without thoroughly cleansing them from ticks. It should be noted that this method, as described, is only suitable for dealing with the tick which carries the redwater organism, which requires to pass through the egg stage in its progress from host to host.

The Feed-lot Method.-This method is based upon the same considerations in regard to the life-history of the tick as the last. To put it into practice, a field on which forage has been sown is taken, and within it three separate enclosures or "feedlots" are made, as shown in the diagram. The tick-infested cattle are removed from their customary pasture, and placed in one of these enclosures for twenty days, then transferred to the next for another twenty days, when, in most cases. they will be free of ticks, and can be turned into the forage field. If, however, ticks are still present, the cattle are placed in the third enclosure for fifteen days more, before being passed into the forage field.

All ticks which were on the animals when placed in the feedlots will, by this time, have dropped off, and the feed-lots are at once plonghed, their edges sprayed with Beaumont oil or other tick-destroving agent, and the soil cultivated. The cattle are kept on the forage till some five months after they were drawn from the pasture, by which time the latter has lost its ticks by starvation, and the eattle may then be returned to it. It is essential that the feed-lots be enclosed by a fence, board-tight along the ground, to keep the ticks ont of the forage field. and it is recommended that a furrow be thrown up on both sides of the fence for the same purpose. The feed-lots should be situated at the boundary of the field, so that the eattle may pass from one to the other over the adjoining tick-free ground.

The Pasture Rotation Method.-The infected pasture is divided into two parts by a double line of fencing $10 \mathrm{ft}$. apart. All tickinfested animals are excluded from the first half of the pasture, from 1st June to 10 th November, thereby rendering it tick-free. The tick-infested cattle are placed on the second half, where they are kent from 1st Jume to 10th September. They are then partly cleaned of ticks by putting them in a cultivated field, cleared of its erop, for twenty days. The partly-cleaned cattle are then removed to a second cultivated field, where the remaining ticks will fall off within twenty days, but if any remain they are trans- 
ferred to a third field for a like period. On 10th November the clean cattle are returned to the first half of the pasture, which by this time has become free from ticks. Here they are kept till Nay, by which time the ticks in the second half have perished. The final result is that both pasture and eattle are free from ticks.

A single female tick may lay as many as 5,000 eggs, and her progeny may, in the course of seven months, come to number $6,750,000,000$ individuals. It has been caleulated that one beast may, as a result of tick infestation, lose as much as $500 \mathrm{lbs}$. of blood in a season. This is quite credible when the fact is borne in mind that a female tick, fully gorged with blood, weighs thirty times more than before it began to engorge. No less than $28 \mathrm{lbs}$. of ticks were taken from a horse which died from anaemia resulting from gross tick infestation. A beast, badly infested, weighed $730 \mathrm{lbs}$. It was freed from ticks by dipping, and two months later-its food and general treatment remaining the same as before dipping - it had gained $285 \mathrm{lbs}$. Newly-hatched ticks can live as long as eight months without food, even during the colder season. In one experiment, cows badly infested with ticks produced $42 \frac{1}{2}$ per cent. less milk than cows kept free from ticks.

Finally, the total annual loss sustained as a result of ticks in the United States is set down in the offieial year book as $100,000,000$ dollars, or nearly $£ 21,000,000$.

\section{DEHORNING CATTLE.}

"In the Argentine very large numbers of the cattle bred for slaughter are dehorned in their youth, with the view, of course, of saving injury when transporting takes place from ranch to freezer. In Australia this has not been done, consequently considerable losses have been attributed to injury by the horns of animals which are driven or transported to the freezer.

"It is well known that polled or dehorned cattle can be managed and fattened with greater facility than horned animals, and that, where a consignment consists solely of hornless eattle, the animals can be conveyed by sea or land with less danger of sustaining injury whilst in transit. The opinion of salesmen and feeders of experienee in the cattle trade is to the effect that steers for export, when horned, require more space in railway waggons, on board ships and in the market place that they receive more injury in transit and that they are worth from 10s. to 15s. per head less than hornless cattle. 


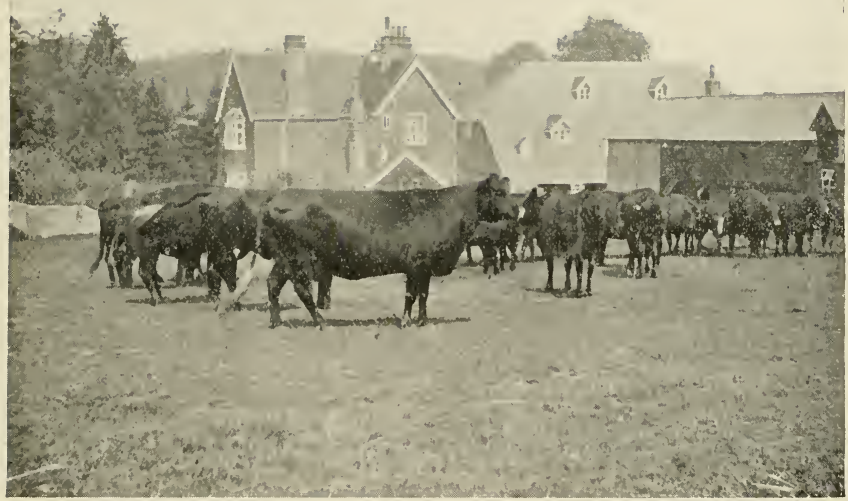

The BatlifF's House at Lord Rothschild's, Tring, lingland. WITH a GROUP OF RED POLLS.

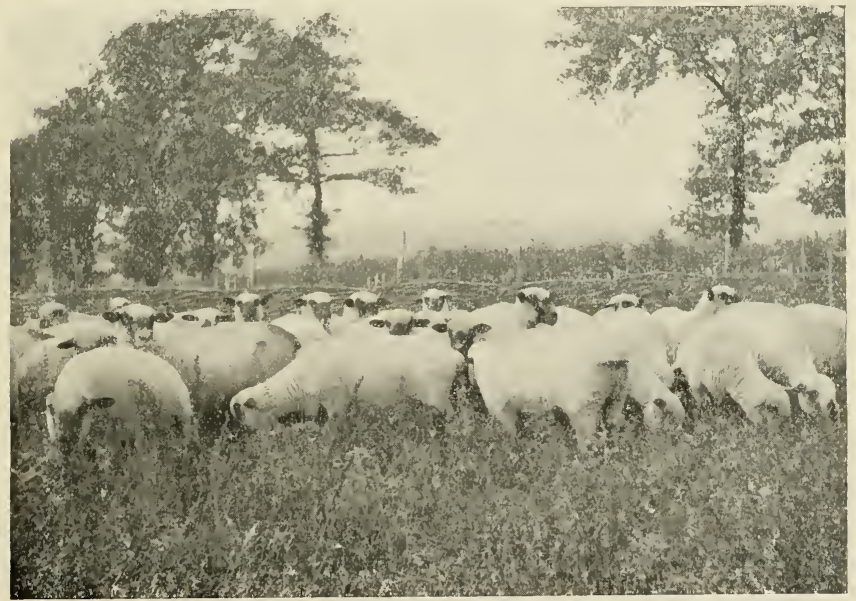

Lord Rothschild's Hampshire Down Six Months Rams, Tring, England. 
"The practice of dehorning cattle, by sawing off or otherwise entirely removing the horns after they are partly or fully grown, appears to inflict great pain upon the animals, and may even be the eause of death. A method of preventing the growth of the horns is by the application of caustic potash to the horn buds of young calves. If performed in the manner set out below, and with proper regard to the precautions which follow, the operation is comparatively painless, and ean be done quickly and with ease :-

"Clip the hair from the top of the horn when the ealf is from two to five days old. Slightly moisten the end of a stick of caustre potash with water (or moisten the top of the horn bud), and rub the tip of each horn firmly with the potash for about a quarter of a minute, or until a slight impression has been made on the eentre of the horn. The horn should be treated in this way from two to four times at intervals of five minutes.

"If, during the interval of five minutes after one or more applications a little blood appears in the centre of the horn, it will then only be necessary to give another very slight rubbing with the potash.

"The following directions should be carefully ohserved:--

" 1 . The operation is best performed when the calf is under five days old, and should not be attempted after the ninth day.

"2. Caustie potash ean be obtained from any chemist in the form of a white stick. When not in use, it should be kept in a stoppered glass bottle in a dry place, as it rapidly deteriorates when exposed to the air.

"3. One man shonld hold the ealf while' an assistant uses the caustic.

"4. A piece of tinfoil or brown paper should be rolled round the end of the stick of caustic potash which is held by the fingers, so as not to injure the hand of the operator.

" 5 . The stick should not be moistened too much, or the caustic may spread to the skin around the horn, and destroy the flesh. For the same reason, the calf should be kept from getting wet for some days after the operation.

"6. Care should be taken to mub on the centre of the horn, and not round the side of it." (Weddel \& Co., Ltd., to The Transvaal Landowner's' Assoeiation.) 
The National Provisioner in an interesting article, says:"The census of the United States has provided average live and dressed weights of meat animals killed in the wholesale slanghtering and meat packing industry, and these averages, of course, are derived from an immense number of animals. Information is provided for 1899, 1904, and 1909.

"The average live weight of beeves, not including calves, was 1069 lbs. in 1899, 1047 lbs. in 1904, and 1019 lbs. in 1909 . This declining average may be due to the tendency to slaughter steers at younger ages in recent years than formerly.

"The dressed weight of beeves also declined, the average being $583 \mathrm{lbs}$. for 1899, $569 \mathrm{lbs}$. for 1904, and $543 \mathrm{lbs}$. for 1909.

"With diminishing live weight the percentage represented by the dressed weight has declined, the percentage for 1899 was 54.5 , for $190+$ it rias 54.3, and for 1909 it was 53.3 per cent.

"On the other hand, the live and dressed weights of calves have increased. For the three years in order the average live weight was 141, 167, and $168 \mathrm{lbs}$, and the average dressed weight was 90,103 and $105 \mathrm{lbs}$. But the dressed weight as a pereentage of live weight has declined since 1899 . The ratios for the three years are 63.861 .7 , and 62.5 per cent. respectively.

"Sheep and lambs are combined in the census statement, and their average live weight for the three years was 84,86 , and 81 lbs., while their average dressed weight was 43,43 , and 41 lbs., constituting a fraction of live weight represented by 51.2 , 50 , and 50.6 per cent. respectively.

"In the export frozen and chilled beef trade of Argentina the average weights of two forequarter's and two hindquarters are regarded as making the dressed weight of a beef animal. Since these are mostly well-grown steers, the averages are high compared with the average dressed weight of all cattle slanghtered in the wholesale slanghtering industry. The Argentine export dressed weights of beef animals increased from 689 lbs. in 1906 to 767 lbs. in 1913.

"A slaughter record in Queensland (Australia) provides average dressed weights of beef animals from 1903 to 1912 which ranged from 577 to $662 \mathrm{lbs}$. Since 1904 the averages have, on the whole, declined. 
"The record for Uruguay presents a quite uniform series of average dressed weights of beef eattle from 1905 to 1910 ; they ranged from $558 \mathrm{lbs}$. to $580 \mathrm{lbs}$.

"The dressed weight of export sheep and lambs in Argentina is considerably above the average in wholesale slaughtering houses in the United States. The Argentine average ranged from 53 to $65 \mathrm{lbs}$. from 1906 to 1913 . The cold storage mutton and lamb for supplying the Buenos Aires city market had a dressed weight that ranged from 37 to 45 lbs. from 1906 to 1912.",

\section{VENISON.}

There seems no reason why much wider use should not be made of venison. It is an old trade, and before the war the United States was a very large eustomer of Great Britain in this respect. The Americans themselves have evidently been looking round in other directions for a kindred supply, and a State's authority predicts that the day will soon come when reindeer meat will be as common as beef or mutton in the American markets, as the result of an investigation into conditions in Alaska. The meat will come from Alaska. It will form the basis of a large packing industry, and will be shipped in cold storage steamers and trains to every town in the United States. There are now from 75,000 to 100,000 reindeer in that territory. They are being handled under Government regulations, and are doubling in number every two or three years. At the present rate of increase there should be $1,000,000$ in 1925. By 1931 the number should have increased to more than $3,000,000$ and five years later it might be almost $13,000,000$. That will be only twenty years from now and after that the increase should be such that reindeer meat will probably be as cheap as any other in the American markets. 


\section{A STATISTICAL STUDY OF BODY WEIGHTS; GAINS AND MEASUREMENTS OF STEERS DURING THE FATTENING PERIOD.}

(In The United States Journal of Agricultural Rescarch, 1917.) During the winter months of 1914-1915, 1915-1916, and 19161917, a series of body measurements of steers were made at the Pennsylvania Experiment Station, at the beginning and close of feeding experiments, for three consecutive years, with the purpose of determining the average body measurements of 2 -year-old steers at the beginning and close of the fattening period and the relationship of other definite body measurements to each other, and to note those measurements that could be used in selection as a means of redncing the experimental error in feeding experiments and a study of variation in the measurements themselves. Another object was to find out the correlation of gains to initial body measurements and to changes in body dimensions.

All measurements taken on a total of 216 animals divided into seven lots each year are indicated in Table I. These steers were relatively uniform as feeders, varying in market grades from "fair" to "choice," the majority being "good" feeders; 92 were Hereford grades, 84 Shorthorn grades, 18 Aberdeen Angus grades, 7 Shorthorn $\times$ Hereford crosses, 3 Shorthorn $\times$ Aberdeen-Angus erosses, and 3 Hereford $\times$ Aberdeen-Angus erosses. In no case did a steer fail to show some infusion of improved beef blood. The average initial weight of the 216 steers was 900.112 pounds, with 700 and 1300 pounds as extremes. The steers were as uniform in quality, weight, and condition as would ordinarily be obtained for feeding purposes. Each year 60 steers were divided into five lots of 12 each selected with as much care for uniformity of weight, breeding, condition and quality as possible. The feeding of these various lots was done with rations affording very nearly the same opportunity for gains in live weight and condition of flesh for marketing.

Table I. includes all records for the three years, while the correlation tables include the data during the first two years. All body measurements except eircumferences were made with the steel caliper; all circumferences were measured with a steel tape graduated in inches. The probability of error in measurements is a factor not considered, thus necessitating a large number of measurements to reduce the probable error. 
T.AbLe I.-Average initial and final measurements of 2-year-old steers fattened for market during a 140-day feeding period.

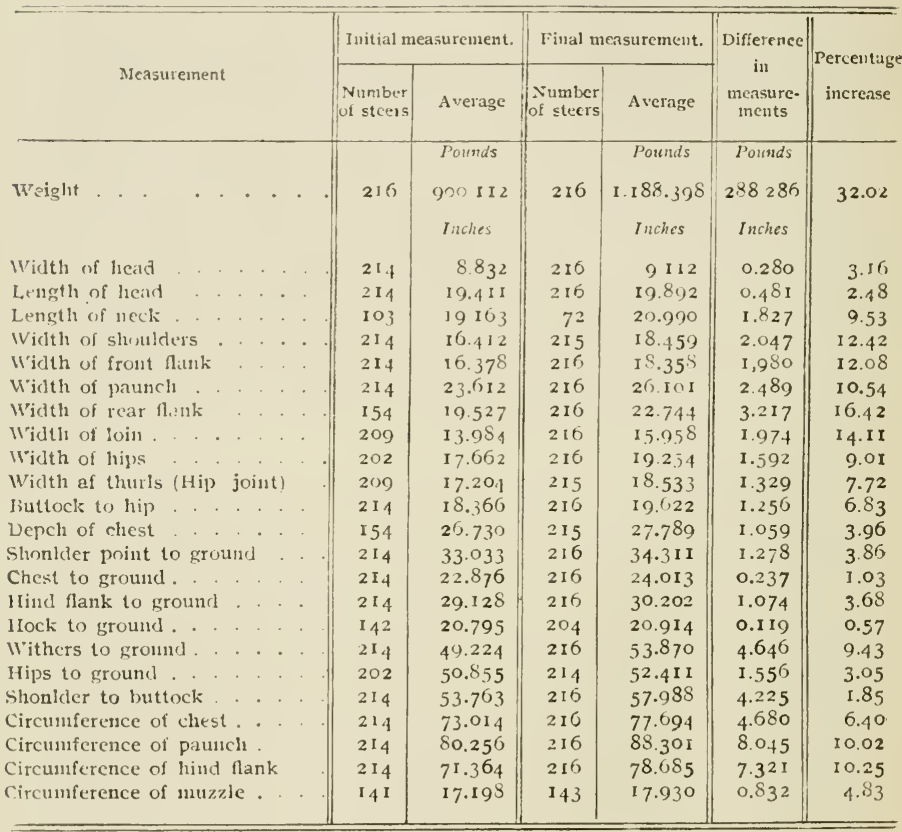

These 216 steers gained at the rate of 2.058 pouncls daily for 140 days.

The following average initial measurements show a marked similarity : the length of head, length of neck, and width of rear flank, which vary from 19.163 to 19.527 inches; the width of shoulder and front flank differ by only 0.034 ineh; the hips and thurls (hip joint) in width are 17.682 inehes and 17.204 inches, respeetively; and circumference of the body in the region of the chest and hind flank are 73.014 and 71.364 inches respectively. 'The height at the withers of a "feeder" steer is 1.631 less than the height at the hips. The length of body from shoulder point to buttock is only 2.908 inches greater than the greatest height at the hips. 
The average measurements at the conclusion of the fattening period show similarity as follows: The length of head, width of hips, and distance of buttock from hips varying within 0.638 inch of each other; the width of shoulder, front flank, and thurls are almost identical; and the cireumference of the ehest and hind flank are more alike than their initial measurements.

The height has increased more at the withers than at the hips; thus a 2-year-old steer changes his greatest height from the hips to the withers while receiving market conditions. In circumference the increase was greater for the hind flank than for the chest; thus the greater circumference of the chest at the initial measurement becomes less than the circumference of the hind flank in the finished steer. In fattening, the greatest width at paunch and the greatest depth of body at the chest become more nearly alike, as shown by a difference of 3.118 inches at the initial measurement and 1.688 inches at the concluding measurement.

In all cases the difference between the initial measurement and the final measurement shows an increase in dimensions due to depositions of fat, muscular development and growth. The regions of the body covered by the greatest amount of muscular development show greater inereased dimensions than those having less muscular covering.

In the regions where the growth would show the greater relative influence the least changes take place as shown in the width of head, length of head, distance from ehest to ground and hock to gromud. The greatest inerease in width took place in the hind flank rather than in the paunch, where it would seem natural to have the greatest increase because of feed capacity and condition. The thick layer of flesh and fat deposits in the region of the hind flank, together with the distension of this region of the body in a fattened steer, are responsible for the greater width in this part of the body. The width of loin, hips, thurls, shoulders, and front flank shows changes in dimensions caused mainly by increased condition of flesh.

The increase in height at the withers of 4.646 inches is not all due to growth alone, a larger portion of this increase being caused by the flesh covering over the withers and the deposition of fat in the muscular tissues of the shoulder region. The fat deposits and muscular development causes the shoulder blade to be held more rigidly; thus, the body in the chest region rises between 
the shonlder blades, as indieated by the greater distance between the withers and the upper border of the shoulder blade. The greatest change in the body measurements was the cireumference of the pameh. This however, was proportionately less than the increase of 7.321 inches in circumference of the hind flank. The fact that the distance of ehest to ground and hind flank to ground did not show greater difference was due to lowering of the flank by deposition of fat in that region and the fat covering over the region of the chest. The region of the body possessing the most valuable eatable parts on the whole are affected most in the fattening process.

Correlation Tables.-The following table is here presented as illustration of the methods used in obtaining the facts presented in Tables III. and IV.:-

TABLE II.-C'orrelation of acerage daily gain of steers during a feeding period of 120 to 140 days and the weight at the beginning of a feeding period.

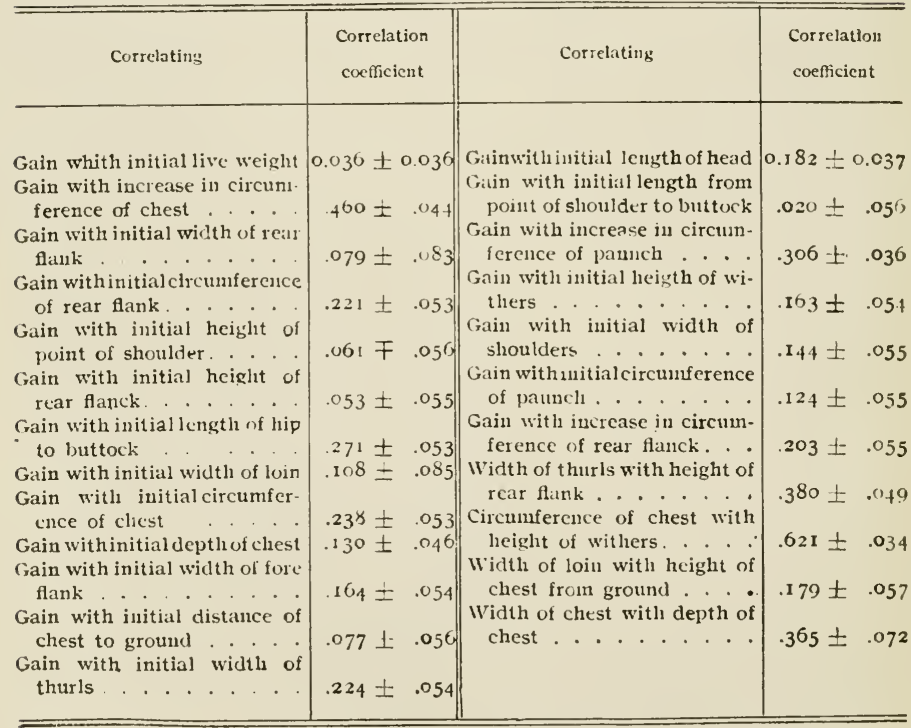


The results shown in Table III. are based on data collected on steers during the two winter periods of 1914-15 and 1915-16. All measurements considered in this table are initial measurements except those that show increases of dimensions at the close of the fattening period as compared with the initial measurements. The coefficient of variation is shown to be greatest on increases in circumference of hind flank, paunch, and chest, and the increase in gains in live weight.

These measurements all relate to increased dimensions and oceur in those parts of the body that show relatively high percentage increase over initial body measurements (Table I.).

of the initial measurements the greatest coefficient of variation is $11.9 \pm 0.04$ per cent. for initial live weight. In all the chest measurements the coefficients of variation are relatively high: Width at point of shoulder $9.3+0.52$, width of fore flank 10.4 +0.6 , depth of chest $6.1+0.34$, and circumference of chest $6.9 \pm 0.39$. Likewise the mid and posterior regions of the bodv show variations, the rear flank with a coefficient of variation of $8.7 \pm 0.48$, ciremmference of rear Hank $6+0.34$, width of loin $7.5 \pm 0.43$, width of thurls $5.9+0.34$, circumference of paunch $11 \pm 0.62$ and distance of hips to buttock $5.2+0.29$.

The measurements affected most by growth show the least variations and include the distance of shoulder point, rear flank. and withers from the ground, length of head, and distance of shoulder point to buttock.

In general, Table III. shows the greatest variation in those regions of the body which change most in a fattening steer and those regions affected most by deposition of fat and development of muscular tissue. 


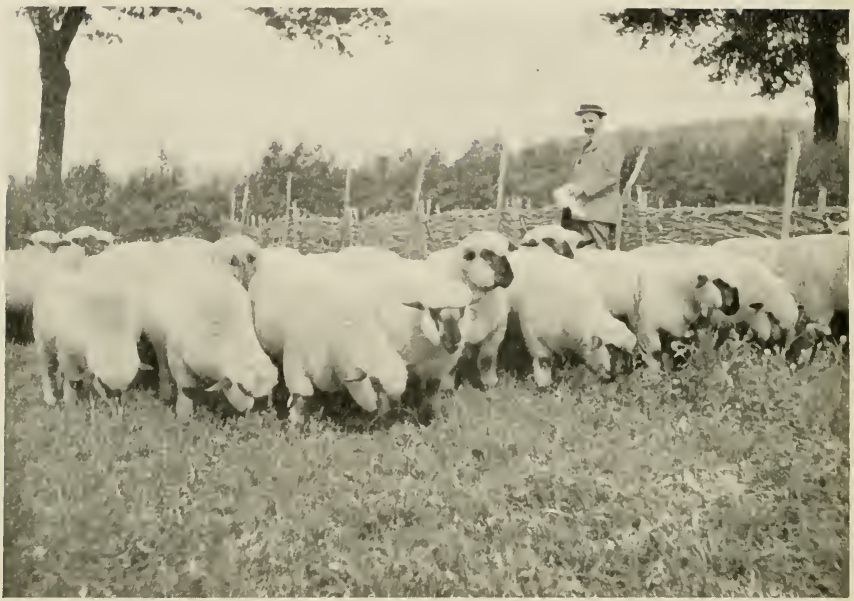

Lord Rothschild's Hampshire Down Ewes, Tring, England.

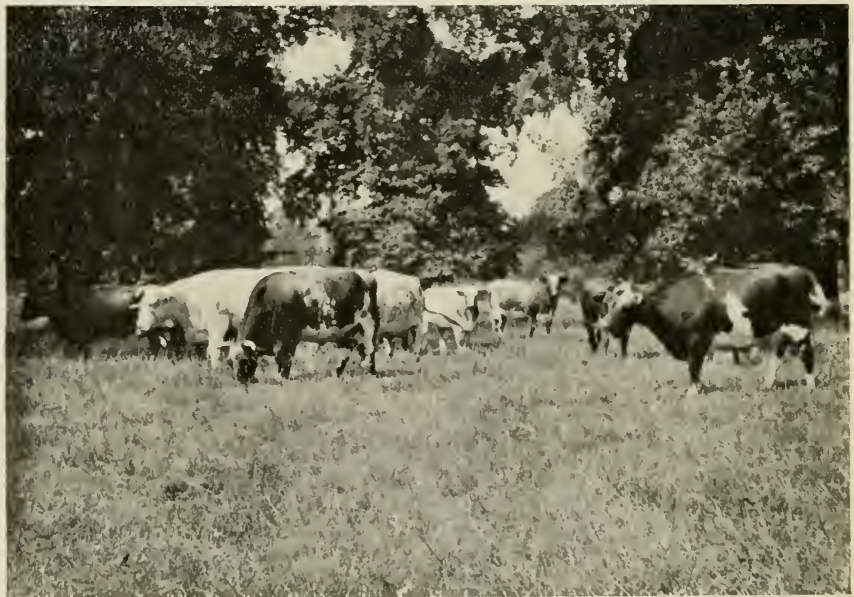

Group of 2-year-old Heifers and Cows at the Royal Farm, WINDSOR, ENGLAND. 


\section{STATISTICAL STUDY OF BODY WEIGHTS 261}

TABLE III.-Means, standard deviations, and coefficients of variation presented in correlation tables.

\begin{tabular}{|c|c|c|c|c|}
\hline $\begin{array}{c}\text { Number } \\
\text { of } \\
\text { stecrs }\end{array}$ & Mcasurements & Mlean & Standard deviations & $\begin{array}{l}\text { Cocfficicut } \\
\text { of variation }\end{array}$ \\
\hline & & pounds & pounds & Per cent \\
\hline 388 & Average daily gain . & $1.93 \pm 0.016$ & $0.446 \pm 0.01 x$ & $23.1 \pm 0.8_{4}$ \\
\hline 388 & Initial live weight .. & $893.93+3.94$ & $106.89 \pm 2.77$ & $11.9 \pm .04$ \\
\hline 142 & Total gain in live waight & $\begin{array}{c}288.55 \pm 3.10 \\
\text { Inclies }\end{array}$ & $\begin{array}{l}54.77 \pm 2.19 \\
\text { Inches }\end{array}$ & 19. I \pm 1.08 \\
\hline 142 & $\begin{array}{l}\text { Jitcreasc in circumference } \\
\text { of cliest }\end{array}$ & $8.13 \div$ I0 & +.074 & $23.0+1.30$ \\
\hline 142 & Width of rear flink. . & $1925 \div .09$ & $1.69 \pm .06$ & $8.7 \div .4^{8}$ \\
\hline 142 & Circuinf erence of rear tlauk & 72.76 上 .25 & $4.10 \perp .17$ & 6.0 t: .34 \\
\hline 142 & Height of shoulder point & $34.10 \div .08$ & $1.57 \doteq .06$ & $4.5 \pm .25$ \\
\hline 142 & Height of reas flank. . & $30.23 \pm 9$ & $1.67 \pm .00$ & $5.5 \pm .31$ \\
\hline 142 & Distance, hip to buttock & $18.69 \div .05$ & $99 \pm .03$ & $5.2 \pm .29$ \\
\hline I 37 & Width of loin .... & $13.9^{6} \pm .06$ & $1.05 \pm .22$ & 7.5 t .43 \\
\hline 142 & Circumference of chest & $69.82 \geq .22$ & $3.91 \pm .01$ & $6.9 \pm .39$ \\
\hline 142 & Depth of chest.... & $25.77-.08$ & $1.59 \pm .053$ & $6.1 \pm .34$ \\
\hline $1+2$ & Width of fore flank. . . & $1502 \pm .08$ & $1.57 \pm .06$ & $10.4 \pm .60$ \\
\hline $\mathbf{J}^{2}$ & Distance, chest to gromul & $22.89 \pm . n 6$ & $1.18 \pm .04$ & 5.1 $干 .28$ \\
\hline $13^{6}$ & Wiclth of thurl.... & $17.36 \pm .05$ & $1.03 \pm .04$ & $5.9 \div .34$ \\
\hline 142 & Length of liead. . . . . & $19.53 \pm .04$ & $.81 \pm .03$ & $1.1 \mp .23$ \\
\hline 142 & $\begin{array}{l}\text { Length of shoulder to } \\
\text { buttock . . . . . } \\
\text { Increase in circumference }\end{array}$ & $55.66 \pm .17$ & 3.02 上 2.84 & $5.4 \pm \cdot 30$ \\
\hline 142 & of pauncli ..... & $8.26 \pm .16$ & $2.95 \pm .11$ & $35.8 \pm 2.02$ \\
\hline 142 & Height of withers. . . & 49.50 士 1.07 & $1.95 \overline{\mp ~ .07}$ & $4.9 \pm .27$ \\
\hline 142 & Width at point of shoulder & I6.42 上 .08 & $1.5 . t \pm .06$ & $9.3 \pm .52$ \\
\hline 142 & Circumference of paunch. & $81.60 \pm .56$ & $10.04 \pm 4.02$ & $10.0 \pm .62$ \\
\hline 138 & of rear flank.... & $17.52 \pm .20$ & $3.5 \mathrm{I} \pm .14$ & $46.6 \pm 2.67$ \\
\hline
\end{tabular}

Table IV., a summary of the coefficients of correlation, shows that increases in body measurements have a closer relationship with gains in live weight than the initial measurements. With the exception of initial weight these measurements, as shown in Table II., also had high coefficients of variation.

The correlation coefficients for the two body circumferences of chest and rear flank, the width of thurls (hip joint), and the distance of hip to buttock show the elosest relationship of all the initial measurements with gains in live weight. This suggests the possibilities of using these measurements in the selection of feeding steers, at least for experimental purposes, as a means of reducing the experimental error caused by individuality of animals. 


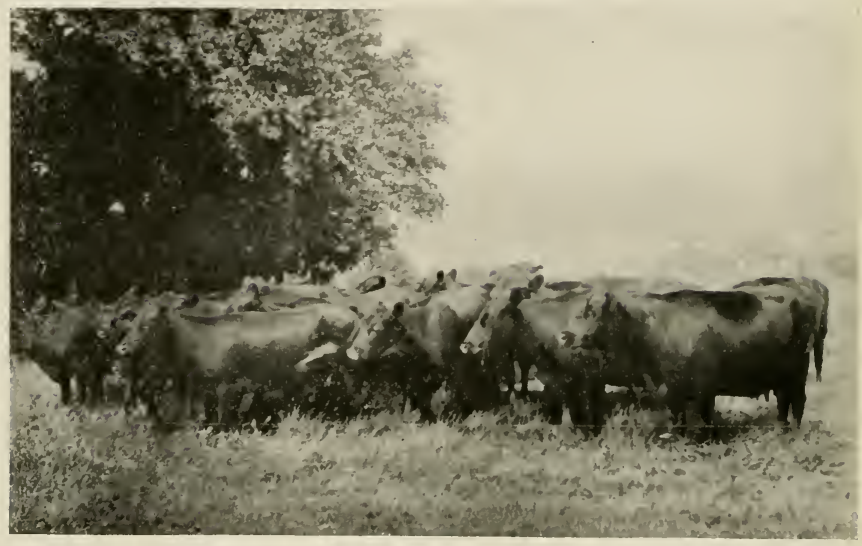

Red Poll Dairy Herd, Property of Mr. J. E. Quested, Kext, Exglaxd.

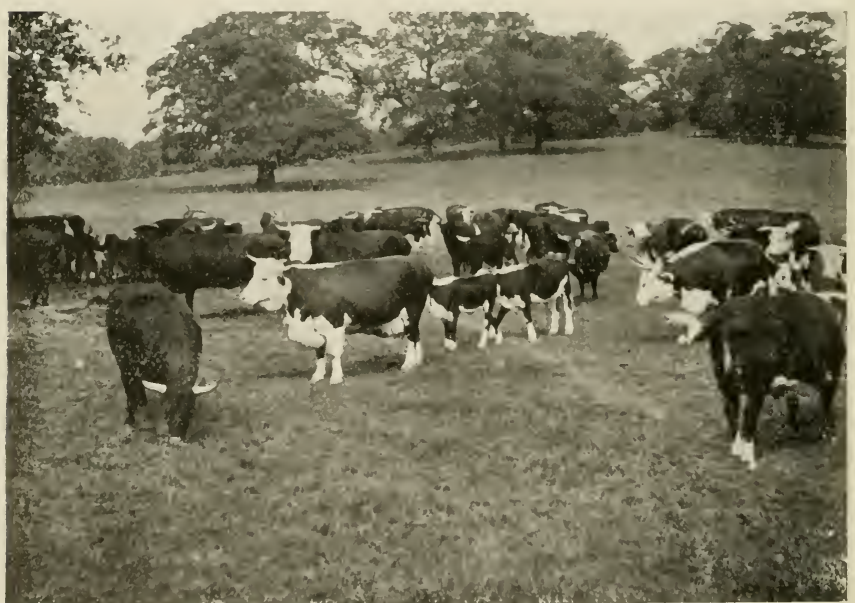

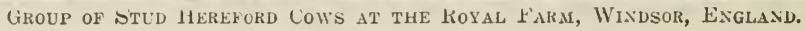


The measurement of initial weight shows no relationship with gains, although this is usually considered one of the most important factors in selection of steers for experimental purposes.

Measurements that show intermediate relationship as indicated by coefficients of correlation are width of loin, depth of chest, width of fore flank, length of head, height of withers, eireumference of paunch and width at shoulders.

TABLE IV.-S'ummary of correlations.

\begin{tabular}{|c|c|c|c|c|c|c|c|c|c|c|c|c|c|c|}
\hline \multirow{2}{*}{$\begin{array}{c}\text { Daily } \\
\text { gain } \\
\text { (pounds) }\end{array}$} & \multicolumn{13}{|c|}{ Initial weight per steer (pounds) } & \multirow{2}{*}{ ङ્ّ } \\
\hline & 1300 & 1250 & 1200 & 1150 & I 100 & 1050 & I 000 & 950 & 900 & 850 & 800 & 750 & 700 & \\
\hline 3.2 & - & - & - & - & - & - & - & I & 一 & - & - & - & - & 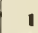 \\
\hline 3.0 & - & - & - & - & - & - & - & 一 & - & - & 一 & - & 一 & 0 \\
\hline 28 & - & - & 一 & 一 & I & $\mathbf{I}$ & 3 & I & I & 2 & I & I & - & 11 \\
\hline 26 & - & - & 一 & - & - & 4 & 2 & 2 & 4 & I & 3 & 3 & I & 20 \\
\hline 2.4 & - & I & 一 & I & 2 & I & 5 & 8 & II & 7 & 6 & 3 & 2 & 47 \\
\hline 2.2 & - & I & - & 2 & 2 & - & 4 & 7 & 4 & 7 & 4 & 5 & - & 36 \\
\hline 2.0 & I & 1 & - & 3 & - & I & 4 & 7 & 9 & I6 & 9 & I 2 & 2 & 65 \\
\hline I. 8 & - & I & - & 3 & 2 & 2 & 5 & 7 & I I & 10 & 9 & 7 & 6 & 63 \\
\hline I 6 & - & - & 1 & - & - & I & 5 & 3 & 5 & 4 & 4 & 5 & 4 & 32 \\
\hline 1.4 & - & 一 & 一 & 1 I & 2 & - & 4 & 4 & ro & 3 & 7 & I & I & 33 \\
\hline I. 2 & 一 & - & 2 & - & - & 2 & 2 & 4 & 2 & 6 & 2 & I & I & 22 \\
\hline 1.0 & - & - & - & - & - & - & - & I & 2 & - & I & I & - & 5 \\
\hline 0.8 & - & - & - & - & - & I & - & - & 2 & - & - & 一 & - & 3 \\
\hline Total & 1 & 4 & 3 & 10 & 9 & 13 & 34 & 45 & 61 & $3 \varepsilon$ & 46 & 39 & $1 \%$ & 338 \\
\hline
\end{tabular}

Mean live weight. . . . . . . . . . pounds $893.93 \pm 3.94$

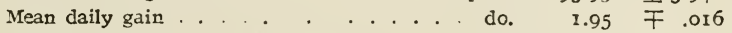

Standard deviation of live weight. . . . do. $106.88 \pm 2.777$

Standard deviation of daily gain . . . . . do. $0.446 \pm .0$ I I

Correlation. . . . . . . . . . . do. $0.0364 \pm .036$

Measurements in which slight or no relationship exist as shown by correlation eoefficients are initial live weight, width of rear flank, height at shoulder point and the distance of rear flank and chest from the ground.

A close relationship of circumference of chest with height of withers is indicated by $r \pm 0.621+0.034$. Likewise, the width of chest and depth of ehest by $r=0.365 \pm 0.072$ show a definite relationship. 
The hind quarters of a steer are more important than the fore quarters in determining the gaining eapacity of a steer, with the exception of the circumference of chest as shown by a correlation coefficient of $0.224+0.054$ for width of thurls, 0.271 \pm 0.053 for distance of hip to buttock and $0.221 \pm 0.053$ for circumference of rear flank.

The circumference of chest and rear flank are more important in ascertaining gains than feed capacity as indicated by the circumference of paunch. 


\section{LIST OF MEAT CANNING AND PRESERVING WORKS}

\section{IN AUSTRALASIA.}

\section{NEW SOUTH WALFS.}

Alexandria Meat Preserving works, Alexandria.-Capacity, 80,000 12-oz. tins per week.

Angliss and Co. (N.s.w.) Prop. Ltd., Wm., Daroobalgie Freezing Works, Forbes. - Capacity, 60002 -lb. tins preserved meat per day.

Barnes Itd., James, Alexandria.-Capacity, 24,000 12-oz, tins preserved meat per day.

Byron Bay Packing and Chilling Company Ltd., Byron Bay.-Capacity, 11,000 24-oz. tins preserved meat per day.

Cooke and Co. Prop. Itd., John, Sandown Freezing Works, Parramatta.Capacity, 10,000 12-oz. tins preserved per day.

Glen Packing Company, Camperdown.-Capacity, 33,000 24-oz. tins: preserved meat per day.

Hunter River Meat Preserving Company Itd., Leichhardt.-Capacity, $20,00024-\mathrm{oz}$. tins preserved meat daily.

Kensington Meat Preserving Company, Ramornie.

Lilyfield Packing Company, xtd., Leichhardt.-Capacity, 15,000 24-oz. tins preserved meat per day.

Iittle and Co., Robert, Merriwa.-Rabbit canning works.

National Meat Preserving Company, Ltd., Balmain.-Capacity, 33,000 24-oz. tins preserved meat per day.

North Coast Co-operative Company Limited, Byron Bay-Capacity, approximately $15,0001-1 \mathrm{~b}$. tins preserved meat per month.

o.x. Meat Company, South Grafton.

Sydney Meat Preserving Company Ltd., Auburn.-Capacity, 3500 6-1b. tins preserved meat per day.

Union Meat Company Limited, Tibbereena.-Capacity, 6000 2-1b. tins pre. served rabbits daily.

Also rabbit canning works at Coonamble, with capacity of 3000 2-1b. tins daily.

VICTORIA.

Angliss and Co. Prop. Itd., Wm., Imperial Freezing Works, Footscray.Capacity, 100 cattle and 1000 sheep per day.

Borthwick and Sons (Australasia) Ltd., Thos., Portland Freezing Works, Portland.-Capacity, 20 cattle per day.

Clark and Son Prop. Lta., E. A., Victorian Export Canning Works, Spotswood.-Capacity, 2000 to 3000 lbs. meat per day.

Flemington Meat Preserving Company Prop. Ltd., Lang's-road, Ascot Vale. - Capacity, 25,000 24-oz. tins preserved meat per day. Accommodation provided for slaughtering 2500 sheep per day.

Geelong Harbour Trust, Corio Freezing Works, Geelong.

\section{QUEENSLAND.}

Australian Meat Export Company Itd., Alligator Creek Freezing Works, Townsville.-Capacity 150 cattle per day.

Brisbane River Freezing Works, Brisbane-Capacity, 150 cattle per day.

Baynes Bros., Queensport, Brisbane-Capacity, 80 cattle per day.

Bergyl Australia Ltd., Bowen Meat Freezing Works, Bowen.-Capacity, 50 cattle per day.

Birt and Co. Ltd., Biboohra, Cairns.-Capacity, 150 cattla per day.

Borthwick and Sons (Australasia) Ltd., Thomas, Moreton Freezing Works, Brisbane.-Capacity not specified.

Central Queensland Meat Export Company Ltd., Lakes Creek Freezing Works, Rockhampton.-Capacity, 40,000 lbs. meat per day. 
Cooke and Co. Prop. Itd., John, Redbank Freezing Works, via Brisbane.Capacity, 50, cattle per day.

Queensland Meat Export Company Itd., Eagle Farm Freezing Works, Brisbane.-C'dpacity, i0 cattle per day.

Ros : River Frtezing Works, Townsville-Capacity, 36,000 lbs. meat per day.

Rosewarne (Queensland) Itd., Frisbane-Capacity, 1000 cattle per week.

\section{SOUTH AUSTRALIA.}

South Australian Government.-Ucean Steamers' Wharf, Port Adelaide.Capacity, $10006-1 \mathrm{~b}$. or $30002-1 \mathrm{~b}$. tins of meat per day.

Wilcox, Moffin Ltd., Compton, Mt. Gambier.-Csed for canning rabbits only.

\section{WESTERN AUSTRAIIA.}

Proposed.

Nor.-West Meat Works Itd., Carnavon.-Capacity, 1500 sheep per day.

\section{NORTHERN TERRITORY.}

North Australian Meat Co. Itd., Darwin.-Capacity, not specified.

\section{NEW ZEAIAND.}

Borthwick and Sons (Aust.) Itd., Thos., Waitara Freezing Works, Waitara. - Capacity, 40 head cattle per day.

Canterbury Frozen Meat and O.P. Export Co. Itd., Belfast Freezing Works, Belfast.-Capacity, 3000 los. preserved meat per day.

East Coast Co-operative Freezing Co. Itd., Whakatane Freezing Works, 17 hakatane.-Caracity, 50 head cattle per day.

Enterprise Meat Works, Winton.

Feilding Farmers' Freezing Co. Itd., Feilding Freezing Works, Aorangi, Feilding.

Gear Meat Preserving and Ereezing Company of N.z. Itd. Petone Freezing Works, Petone.-Capacity, 3,000,000 1bsd meat per season.

Gisborne Sheepfarmers' Frozen Meat Company Ltd., Kaiti Freezing Works: Gisborne.-Capacity, 5000 lbs, meat per day.

Nelson Bros. Itd., Tomoana Freezing Works, Tomoana.-Capacity, 1000 to 1200 lbs. meat per day.

New Zealand Refrigerating Company Itd., Imlay Freezing Works, near Wanganui.-Capacity, toot los. meat per day.

lslington Freezing Works, Islington.-Capacity, 6000 lbs. meat per day.

New Zealand Farmers' Co-operative Bacon and Meat Packing Co. Itd.Ngahauranga Works, near Wellington.-Capacity, 90 head cattle or 30,000 lbs. meat per day.

Patea Farmers' Co-operative Freezing Co. Itd., 1'atea Freezing Works, Canville.-Capacity, 16,000 lbs. meat per day.

Poverty Bay Farmers' Meat Co. Itd., Waipaoa Freezing Works, Gisborne. -Capacity, 18,000 lbs. meat per day.

Taranaki Farmers ${ }^{t}$ Meat Co. Itd., New Plymouth Freezing Works, New Plymoutl,-Capacity, 9000 libs, meat per day.

Tait, w. E., Woodlands Meat Preserving Works, Invercargill-Capacity, 11,000 lbs. preserved meat per day.

Wanganui Meat Freezing Company Itd., Castlecliff Freezing Works, Castlecliff.-Capacity. 6500 lbs. preserved meat per day.

wellington Farmers' Meat Company Itd. (1), Waingawa Freezing Works, near Masterton.-Capacity, 20,000 lbs. meat daily.

Wellington Meat Export Company Itd., Ngahauranga Freezing Works, near Wellington.-Capacity, 1500 carcases mutton per day.

westfield Freezing Co. Itd., Westfield Freezing Works, near Auckland.Sixty bodies beef per day.

whangarei Freezing Co. Itd., Whangarei Freezing Works, Reatahi, Whangarei Heads. - Twenty bodies beef per day.

(1) Capacity being increased to 50,000 lbs. of meat per day. 
LIST OF REFRIGERATING WORKS EMPLOYED IN THE IEAT EXPORT TRADE IN AUSTRALIA AND NEW ZEALAND.

Giving Approxindte Dally Receivixg and śtorage Capicity.

\section{QUEENSLAND.}

Australuan Meat Export Company Itd., Brisbane River Works, Erisbane. - 750 cattle and 3000 sheep per day, storage capacity, 40,000 quarters beef and 135,060 carcases mutton; total, 4000 tons.

Alligator Creek Works, Townsville. -750 cattle and 2000 sheep per day; storage capacity, 40,000 quarters beef a d 135,000 carcases mutton; total, 4000 tons.

Bergl Australia Itd., Bowen Meat Freezing Works, Bowen,-150 cattle per day; storage capacity, 1500 tons.

Birt and Co. Itd., Musgrave Wharf Cold Stores, South Brisbane.-100 cattle or 1100 sheep per day; storage capacity, 750 tons.

Murarrie Works, near Brisbane. -150 cattle or 1500 sheep per day; storage capacity, 700 tons.

Borthwick and Son's (Australasia) Itd., Thos., Moreton Freezing works, Brisbane. -250 cattle or 4000 sheep per day; storage capacity, 1000 tons.

Burdekin River Meat Preserving Company Ltd., Burdekin Works, Sellheim. -260 cattle or 2000 sheep per day; storage capacity, 1200 tons:

Central Queensland Meat Export Company Ltd., Lakes Creek Works, Rockhampton. -500 eattle or 3000 sheep per day; storage capacity, 3000 tons.

Cooke and Co. Prop. Itd., John, Redbank Works, ria Brisbane.-400 cattle, or 280 cattle and 1600 sheep, pen day; storage capacity, 2800 tons.

Gladstone Meat Works of Queensland Ltd., Gladstone Works, Gladstone.400 cattle or 3500 sheep per day, or 200 eattle and 2000 sheep per day; storage capacity, 2500 tons.

Queensland Government, Charleville Works, Charleville.-Storage capacity, 160 quarters beef, 600 to 800 carcases of mutton.

Queensland Meat Export Company Itd., Eagle Farm Works, Brisbane.330 cattle and 300 sheep, or 150 cattle and 2000 sheep per day; storage capacity, 32,000 quarters beef, or 105,000 carcases mutton; total, 2000 tons.

Ross River Works, Townsville. -750 cattle, or 700 cattle and 1000 sheep, or 600 cattle and 2000 sheep, or 550 cattle and 2500 sheep per day; storage capacity, 88,000 quarters beef, or 290,000 carcases mutton; total, 5500 tons.

\section{NEW SOUTH WAIES.}

Angliss and Co. (N.S.W.) Prop. I.td., W., Daroobalgie WTorks, near Forbes. -4000 sheep and 250 cattle per day, and 4000 crates rabbits weekly; storage capacity, 100,000 carcases lamb.

Australian Chilling and Freezing Conpany Itd., Aberdeen works, near Newcastle.-100 cattle and 3060 sheep per day; storage capacity, 60,000 carcases mutton.

Cooke and Co. Prop. Irtd., John. Sandown Works, near Parramatta. -7000 sheep, or 400 cattle and 3000 sheep per day; storage capacity, 255,000 carcases mutton.

Crystal Ice and Cold storage Company Itd., works, Balmain, Sydney.1500 sheep per day; storage capacity, 40,000 carcases mutton.

Metropolitan Ice and Cold storage Company Itd., works, Harris-street, Sydney. 1200 sheep ver day; storage capacity, 40.000 carcases mutton.

Metropolitan Meat Industry Board, temporary meat distributing depot, Pyrmont, Sydney.- Storage capacity, 1000 carcases mutton. 
Municipal Cold Storage Workz, Sydney.-Storage capacity, 100,000 car cases mutton.

New South Wales Fresh Food and Ice Company Itd., Darling Harbour Works, Sydney.-6000 sheep per day; storage capacity, 170,000 carcases mutton.

Pastoral Finance Association Itd., Kirribilli Point Works, Sydney.-2500 sheep per day: storage capacity, 75,000 carcases mutton.

Riverina Frozen Meat Company Prop. Itd., Deniliquin Works, Deniliquin (shipping, via Melhourne). -1500 sheep per day; storage capacity, 40,000 carcases mutton.

Sydney Ice skating Rink and Cold Storage Company Itd., cold stores, Harris-street, ['ltimo, Sydney. - 2500 sheep per day; storage capacity, 60,000 carcases mutton.

\section{IN COURSE OF ERECTION.}

Walker and Co., F. J., Tibberena Meat Works.-Estimated killing capacity, 1000 sheep and 80 head cattle per day.

Waterside Cold Stores Itd., Jones Bay, Sydney.-Estimated storage capacity, 100,000 carcases mutton.

\section{VICTORIA.}

Angliss and Co. Pty. Itd., Wm.,* works, Bourke-street, Melbourne.-2000 lambs per day; storage capacity, 25,000 carcases lamb.

City Market Cool Stores and Ice Works,* King-street, Melbourne. 2000 carcases lamb per day; storage capacity, 120,000 carcases lamb.

Imperial Freezing Works, Footscray, near Melbourne.-11,000 sheep or lambs and 250 cattle per day; storage capacity, 250,000 carcases lamb or equivalent in beef.

Borthwick and Sons (Australasia) Itd., Thomas, Portland Freezing Works, Portland. -40 cattle and 1100 lambs per day; storage capacity, 20,000 carcases lamb.

Brooklyn Freezing Works. Footscray. -5000 lambs and 50 cattle per day; storage capacity, 76,800 carcases lamb.

Cooke and Co. Prop. Itd., John, Newport Freezing Works, near Melbourne. -Kill 6000 and freeze 4000 lambs per day; storage capacity, 120,000 carcases lamb.

Fletcher Itd., W. and R., North Shore Freezing Works, Geelong.-1600 lambs per day; storage capacity, 28,000 carcases lamb.

Geelong Harbour Trust, Geelong. -200 eattle and 9000 sheep or lambs per day: storage capacity, 150,000 carcases mutton.

Goulburn Valley Industries Company Itd., Shepparton.-160n sheep or lambs per day: storage capacity, 50,000 carcases lamb.

Melbourne Cool Stores and Ice Works (W. Dunkerley, propr.), Flinderslane, Melbourne.-Storage only; capacity, 60,000 carcases lamb.

Melbourne Ice skating and Refrigerating Company, The Glaciarium, Melbourne.-2500 carcases lamb per day"; storage capacity, 45,000 carcases lamb.

Metropolitan Ice and Cold store works (IV. Dunkerley, Propr.), Blackwooustreet, North Melbourne.-Storage only; capacity, 50,000 carcases lamb.

Sennitt and Son Prop. Ltd.,* works, Miller-street, Melbourne.-1000 carcases lamb per day; storage capacity, 30,000 carcases lamb.

Victorian Butter Factories Co-operative Co.,* works, Flinders-street Extension, Mlelbourne.-2000 earcases lamb per day, storage capacity, 50,000 carcases lamb.

Victorian Government,* Victoria Docks Stores, Melbourne.-3500 carcases mutton or lamb per day; storage canacity, 150,000 carcases lamb. ('Total refrigerated slace, 750,000 eubic feet.)

Wimmera Inland Freezing Company Itd., Murtoa Works, Murtoa.-2600 sheep or lambs per day; storage capacity, 60,000 carcases lamb.

* The figures given here denote only such space as is set apart for the frozen meat trade. The total capacity of the works is in most cases considerably larger. The stores are also used for freezing and storing butter, rabbits and other perishable produce. 
SOUTH AUSTRALIA.

South Australian Government, State Refrigerating Works, Port Adelaide.120 cattle and 8000 sheep or lambs per day; storage capacity, 300,000 carcases mutton $(600,000$ cubic feet $)$.

Light Square Works, Adelaide. -3000 carcases mutton per day; storage capacity, 65,000 carcases mutton $(150,000$ cubic feet).

\section{NORTHERN TERRITORY.}

Vestey Bros., Darwin, Northern Territory, 500 cattle per day; capacity, 6000 tons beef, equivalent to about 200,000 carcases mutton.

\section{WESTERN AUSTRAIIA.}

Baker Bros., Works, Fremantle.-100-150 cattle per week; storage capacity, 26,139 cubic feet.

Western Fresh Food and Ice Company, works, Fremantle,-1000 carcases lamb per day; storage capacity, 3500 cubic feet.

\section{IN COURSE OF ERECTION.}

Western Australian Government, Wyndham Works, Wyndham.-Approximately 300 to 400 cattle per day; storage capacity, 16,400 grs. beef -1264 tons.

\section{NEW ZEAIAND.}

Auckland Farmers' Freezing Company Itd., Horatiu Works, Horatiu, Wa1kato -3000 sheep or 220 cattle per d'ay; storage capacity, 180,000 carcases mutton.

Southdown Works, Penrose, Auckland.-3000 sheep or 220 cattle per day; storage capacity, 172,000 carcases mutton.

Auckland Works, Auckland.-Storage only, 130,600 carcases mutton.

Borthwick and Sons (Australasia) Itd., Thos., Paki Paki Works, Hastings, Hawkes Bay. 2000 sheep and 30 cattle per day; storage capacity, 60,000 carcases mutton.

Canterbury Works, Belfast, near Christehurch.-4000 sheep per day; storage capacity, 80,000 carcases mutton.

Waitara Works; Waitara, Taranaki.-2000 sheep and 200 cattle per day; storage capacity, 80,000 carcases mutton.

Canterbury Frozen IMeat and D.P. Export Company Itd., Belfast Works, Belfast, Canterbury. -6000 sheep and 100 cattle per day; storage capacity, 190,000 carcases mutton.

Fairfield Works, Ashburton.-4000 sheep and 25 cattle per day; storage capacity, 80,000 earcases mutton.

Pareora Works, Pareora, near Timaru. -4500 sheep and 35 cattle per day; storage eapacity, 178,000 earcases mutton.

East Coasi Co-operative Freezing Co. Ita. (1) Whakatane Works, Whakatane, Bay of Plenty.-1000 sheep and 200 cattle per day; storage capacity, 100,000 sircases mutton.

Feilding Farmers' Freezing Company Itd., Feilding Works, Aorangi, Feilding.-1400 sheep per day; storage capacity, 130,000 carcases muttcn.

Gear Meat Preserving and Freezing Company Itd., Petone Works, Petone, near Wellington.-10,000 sheep and 100 eattle per day; storage capacity, 400,000 careases mutton.

Gisborne Sheepfarmers' Frozen Meat Company Itd., Kaiti Works, Kaiti, Gisborne. -4500 sheep and 120 cattle per day; storage capacity, 234,000 carcases mutton.

Hawkes Bay Farmers' Meat Company Itd, Whakatu Works, Whakatu, near Hastings. -2000 sheep and 80 cattle per day; storage capacity, 130,000 earcases nutton. 
National Mortgage and Agency Company Lta., Longburn Works, Longburn, near Palmerston North.-1500 sheep and io cattle per day. storage capacity, 120,000 carcases mutton.

Nelson Bros. Itd. - Tomoana Works, Tomoana, Hawkes Bay- -3000 sheep and su cattle per day; storage eapacity, 155,500 carcases mutton.

Taruheru Works, Taruheru, near Gisborne.-3000 sheep and 85 cattle per day: storage capacity, 95,000 carcases mutton.

Hornhy Works, Hornby, near Christehurch.-1500 sheep per day; storage capacity, 64,000 carcases mutton.

Nelson Freezing Company Itd., Stoke Works, Stoke, near Nelson.-350 sheep and 20 cattle per day; storage capacity, 30,000 carcases mutton.

New Zealand Refrigerating Co. Ita., Islington Works, Islington, near Christchurch. - 7000 sheep and 50 cattle per day; storage capacity, 291,000 carcases mutton.

Smithfield Works, Smithfield, near Timaru.-6000 sheep and 50 cattle per day; storage capacity, 186,000 carcases mutton.

Pukeuri Works, Pukeuri, near Oamaru.-3000 sheep per day; storage capacity, 200,000 carcases mutton.

Burnside Works, Burnside, near Dunedin. -3500 sheep and 50 cattle per day; storage capacity, 216.000 carcases mutton.

Picton Works, Marlborough. -1000 sheep and 30 cattle per day; storage capacity, 23,000 carcases mutton.

Imlay Works. Wanganui. -6000 sheep and 200 cattle per day; storage capacity, 250,000 carcases mutton.

New Zealand Farners' Co-operative Bacon and Meat Packing Co. Itd., Eltham Works. Taranaki. -150 pigs and 60 cattle per day; storage capacity, 25,000 carcases mutton.

Frankton Junction Works, Waikato.-300 pigs per day; storage capacity, 25,000 carcases mutton.

Ngahauranga Works, near Wrellington.-1200 pigs, 70 cattle and 600 sheep per day; storage capacity, 50,000 carcases nutton.

Te Aroha Works, Thames Valley. -150 pigs per day.

North British and Hawkes Bay Ereezing Company, Spit Works, Port Ahuriri, Napier.-250\% sheep per day: storage capacity, 50,000 carcases mutton.

North Canterbury Sheep Farmers' Co-operative Freezing Co, Kaiapol Works, near Christchurch. -2500 sheep and 25 cattle per day; storage capacity, 200,000 carcases mutton.

Otaihape Farmers' Meat and Produce Company Itd., Winiata Works, Winiata, near Taihape.-1200 sheep and 50 cattle per day storage capacity, 120,000 carcases mutton.

Patea Farmers' Freezing Company, Patea Works, Canville, near Patea.1500 sheep and 150 cattle per day: storage capacity, 140,000 carcases mutton.

Poverty Bay Farmers' Meat Company, Waipaoa Works, near Gisborne, Poverty Bay.-41000 sheep and 200 cattle per day; storage capacity, 200,000 carcases inution.

Southland Frozen Meat and Produce Export Company Itd., Fluff Workc, Bluff, Southland.-Storage only, 115,000 carcases mutton.

Mataura Works, Mataura, Southland.-2000 sheep and 100 eattle per day; storage capacity. 92,000 carcases mutton.

Wallacetown Works, Makarewa, Southland.-2000 sheep and 120 cattle per day; storage capacity; 74,000 carcases mutton.

South otago Freezing Company Ltd.. Finegand Works, Balclutha, SouthOtago.-2500 sheep and 40, cattle per day: storage capacity, 200,000 carcases mutton.

Taranaki Farmers' Meat Co. Itd., New Plymouth Works, New Plymouth. Taranaki.-1500 sheep and 150 cattle per day: storage caracity, 120,000 carcases mutton. 
Tokomaru Sheepfarmers' Freezing Company Itd., Tokomaru Works, Tokomaru Bay. -3000 sheep and 50 cattle per day; storage capacity. 130,000 carcases mutton.

Wairoa Farmers' Co-operative Meat Co. Itd., Wairoa Works, Wairoa, Hawkes Bay.-2000 sheep and 50 cattle per day; storage capacity, 125,000 carcases mutton.

Wanganui Meat Freezing Company rtd., Castlecliff Works, Castlecliff, Wanganui River, 3000 sheep and 80 cattle per day: storage capacity, 110,000 carcases mutton.

Ward and Co. Ita., J. G., Ocean Beach Freezing Works, Bluff.-3000 sheep and 120 cattle per day; storage capacity, 115,000 carcases mutton.

Wellington Farmers' Meat Company Lta. (2) Waingawa Works, Waingawa, near Masterton.- 7000 sheep and 250 cattle per day; storage capacity, 270,000 carcases mutton.

Kakariki Works, Kakariki, near Marton.-2000 sheep and 50 cattle per day; storage capacity, 100,000 carcases mutton.

Wellington Meat Export Company Ita., Ngahauranga Works, Ngahauranga, near Wellington.-7000 sheep and 130 cattle per day: storage capacity, 240,000 carcases mutton.

Westfield Freezing Company Lta. (3) Westfield Works, near Auckland.2000 sheep and 200 cattle per day; storage capacity, 175,000 carcases mutton.

(1) Storage for an additional 40,000 carcases in course of erection.

(2) Storage for an additional 80,000 carcases in course of erection.

(3) Storage for an additional 50,000 carcases in course of erection.

Whangarei Freezing Company Itd., Whangarei Works, Reotahi, Whangerei Heads. 1200 sheep or 150 cattle per day; storage capacity, 90,000 carcases mutton.

\section{IIST OF FREEZING WORKS OPERATING IN SOUTH AMERICA.} ARGENTINA.

Compania Sansinena de Carnes Congeladas._Torks, Avellaneda, Buenos Ayres; Works, Cuatreros, Bahia Blanca.

Sociedad Avonima Ia Blanca Company.-Works, Buenos Ayres.

Frigorifico Argentino Central Sociedad Anonima.- Wrorks, Buenos Ayres. Compania Swift de la Plata Sociedad Anonima.-Works, Buenos Ayres.

Ia Plata Cold Storage Company.-Works. Buenos Arres.

Frigorifico Armour de la Plata Sociedad Anonima.-Works, Buenos Ayres

British and Argentine Meat Company Itd.-Works, Campana. Works, Zarate.

Smithfield and Argentine Meat Co Itd.-TVorks, Zarate.

Anglo-South American Meat Co.-Works, Zarate.

Swift and Company.- Works, Saladillo.

\section{PATAGONIA.}

New Patagonia Meat and Cold Storage Company.-Works, Puerto Gallegos South American Export Syndicate Itd.-Works, Rio Seco.

I a Compania de Frigorifica, Patagonia.-Works, San Gregorio.

* Ia Compania Frigorifica de Puerto Natales.-Works, Lltima Esperanza.

Cia Explotadora de Tierra del Fuego.- Works, Ultima Esperanza.

\section{URUGUAY.}

Compania Sansinena Frigorifica Uruguaya.-Morks, Monte Video. Frigorifico Monte video (Swift and Co.)- Works, Monte Video. Frigorifico Hall (Vestey and Co.)-Works, Monte Video. Frigorifico Artigas.-Works, Monte Video. Morris and co.-Works, Monte Video. 


\section{PARAGUAY.}

\% Compania Paraguayade Frigorificos de Carnes Congeladas.-(Canning only).

* Central Products Company.-Works, Asuncion; (canning only.)

* Frigorifico San Salvador de Paraguay.-Works, San Salvador.

\section{BRAZIL.}

Frigorifico Armour de Brazil.-Works, Barretos.

Works, Santa Anna.

Compania Frigorifico and Pastoral de Sao Paulo.-Works, Barretos.

Continental Products Co.- Irorks, Ozasco.

Compania Britannica de Carnes.-Works, Rio de Janeiro.

Empreza de Armazeus Frigorifico-Works, Rio.

Central Products Co.-Works, Sao Paulo.

Union Cold Storage Co.-Works, Mendes.

Compania Swift de Brazil.-Works, Rio Grand do Sul.

Port Company.-Freezing and Storage only at Rio.

Companhia Docas de Santos.-Freezing and Storage only at Santos.

\section{VENEZUELA.}

Venezuelan Meat and Products Syndicate Itd.-Works, Puerto Cabello. 



